\title{
High Level Radioactive Waste Vitrification Process Equipment Component Testing
}

D. H. Siemens

W. O. Heath

D. E. Larson

S. N. Craig

D. N. Berger

R. W. Goles

April 1985

Prepared for the U.S. Department of Energy under Contract DE-AC06-76RLO 1830

Pacific Northwest Laboratory Operated for the U.S. Department of Energy by Battelle Memorial Institute 


\title{
DISCLAIMER
}

This report was prepared as an account of work sponsored by an agency of the United States Government. Neither the United States Government nor any agency thereof, nor any of their employees, makes any warranty, express or implied, or assumes any legal liability or responsibility for the accuracy, completeness, or usefulness of any information, apparatus, product, or process disclosed, or represents that its use would not infringe privately owned rights. Reference herein to any specific commercial product, process, or service by trade name, trademark, manufacturer, or otherwise, does not necessarily constitute or imply its endorsement, recommendation, or favoring by the United States Government or any agency thereof. The views and opinions of authors expressed herein do not necessarily state or reflect those of the United States Government or any agency thereof.

\author{
PACIFIC NORTHWEST LABORATORY \\ operated by \\ BATTELLE \\ for the \\ UNITED STATES DEPARTMENT OF ENERGY \\ under Contract DE-AC06-76RLO 1830
}

\begin{tabular}{|c|c|}
\hline \multicolumn{2}{|c|}{ Printed in the United States of America } \\
\hline \multicolumn{2}{|c|}{ Available from } \\
\hline \multirow{2}{*}{\multicolumn{2}{|c|}{$\begin{array}{l}\text { National Technical Information Service } \\
\text { United States Department of Commerce }\end{array}$}} \\
\hline & \\
\hline \multicolumn{2}{|c|}{5285 Port Royal Road } \\
\hline \multicolumn{2}{|c|}{ Springfield, Virginia 22161} \\
\hline \multirow{2}{*}{\multicolumn{2}{|c|}{$\begin{array}{l}\text { NTIS Price Codes } \\
\text { Microfiche A01 }\end{array}$}} \\
\hline & \\
\hline \multicolumn{2}{|c|}{ Printed Copy } \\
\hline & Price \\
\hline Pages & Codes \\
\hline $001-025$ & A02 \\
\hline $026-050$ & $\mathrm{AO3}$ \\
\hline $051-075$ & A04 \\
\hline $076-100$ & A05 \\
\hline $101-125$ & A06 \\
\hline $126-150$ & $\wedge 07$ \\
\hline $151-175$ & A0B \\
\hline $176-200$ & $\wedge 09$ \\
\hline $201-225$ & A010 \\
\hline $226-250$ & A011 \\
\hline $251-275$ & A012 \\
\hline $276-300$ & A013 \\
\hline
\end{tabular}


PNL -5394

UC-70

HIGH LEVEL RADIOACTIVE WASTE VITRIFICATION PROCESS EQUIPMENT COMPONENT TESTING
D. H. Siemens
W. 0 . Heath
D. E. Larson
S. N. Craig
D. N. Berger
R. W. Goles

April 1985

Prepared for the U.S. Department of Energy under Contract DE-AC06-76RLO 1830

Pacific Northwest Laboratory Richland, Washington 99352 


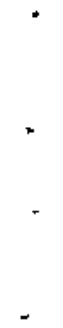

$\therefore$

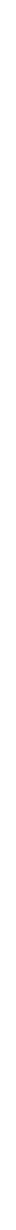




\section{ABSTRACT}

Remote operability and maintainability of vitrification equipment were assessed under shielded-cell conditions. The equipment tested will be applied to immobilize high-level and transuranic liquid waste slurries that resulted from plutonium production for defense weapons. Equipment tested included: 1) a turntable for handling waste canisters under the melter; 2) a removable discharge cone in the melter overflow section; 3) a thermocouple jumper that extends into a shielded cell; 4) remote instrument and electrical connectors; 5) remote, mechanical, and heat transfer aspects of the melter glass overflow section; 6) a reamer to clean out plugged nozzles in the melter top; 7) a closed circuit camera to view the melter interior; and 8) a device to retrieve samples of the glass product. A test was also conducted to evaluate liquid metals for use in a liquid metal sealing system. 


\section{ACKNOWLEDGEMENTS}

The authors acknowledge the valuable contributions made by S. M. Berry, A. B. Carlson, G. N. Buck, J. E. Gose, S. D. Halstead, and F. E. Haun during the design and testing of the HWVP vitrification system components and the invaluable assistance of Naomi Sherer and Sharon Cluck in the generation of this report. Their efforts on this task are greatly appreciated. 


\section{SUMMARY}

A preliminary phase of converting a joule-heated ceramic melter vitrification system to canyon remote operation has been completed. During this phase, ten components, which were identified as requiring additional development and Jesign verification, were fabricated and tested. This report presents the results of this effort.

In general, two types of testing were performed, remote testing and operational functional testing. Typically, remote testing involved evaluating the ability to install and replace equipment components using crane only, canyon remote techniques. All remote testing was conducted in the Pacific Northwest Laboratory (PNL) remote operations testing facility, which was developed as part of this testing effort. The facility consists of a fullsize melter shell, a support structure and mock cell walls in a configuration similar to that planned in the vitrification cell. Nozzles and other flanged openings on the melter shell were used as test sites onto which prototype equipment components were installed and removed.

The support structure was also used to hold a prototype turntable in the correct position relative to the melter shell. To evaluate the feasibility of replacing equipment remotely, the test facility was equipped with fully remote, radio controlled canyon crane and a two-camera, CCTV system for remotely viewing the installation. The CCTV monitors were located behind the mock walls, preventing any individual direct viewing.

The jeneral approach used to evaluate the remote aspects of a design was to fabricate a full-scale prototype and attempt to remotely install and remove it from its test site on the melter shell, turntable or mock wall. This is the most direct approach toward establishing remotability. Using this approach, the following prototypes were built and tested:

- canister positioning turntable and auxilliary equipment

- melter discharge section lid

- discharge cone and handling equipment

- multiple pin instrument jumper 
- thermocouple replacement system

- glass melt sampler

- level detection system ${ }^{60} \mathrm{Co}$ source mobilizing device

To provide a basis for an objective evaluation, criteria were established as shown in the Summary Table. Components were evaluated and developed on the basis of these criteria. All components are remotely replaceable or maintainable by the listed criteria either as originally designed, or with minor adjustments and modifications that became obvious during testing.

The results of remote testing, where each piece of equipment is measured against the criteria it must meet, are shown in the Summary Table. Each component is judged "acceptable as tested" or "further development recommended." Specific recommendations are included in the appropriate sections.

Operational testing established whether and how well a component functioned once installed. The remote and operational tests that were performed are summarized in the following paragraphs.

\section{CANISTER POSITIONING TURNTABLE}

Turntable testing was performed using a full-scale, prototype turntable. The testing was conducted in the PNL remote operations testing facility. A full-size melter shell and support structure were installed to provide a configuration similar to that planned in the vitrification cell. Two candidate drive indexing systems were evaluated for accurately positioning canisters under the melter. The first, a cam-operated system, worked well and can be handled remotely while the second, a potentiometer feedback system, would not adequately align the canister under the melter pour spout. Inserting and removing canisters from the turntable by crane using a canister grapple device was tested using a full-scale canister and found to be feasible. A bellows seal system developed for connecting the melter to the turntable was found to function well with only minimal (acceptable) air inleakage. The canister access hatch and sealing mechanism were found to be feasible for remote handling although further design work is required. A system for continuousiy weighing a canister as it is being filled with glass indicated both good 


\section{SUMMARY TABLE}

Results of Component Testing

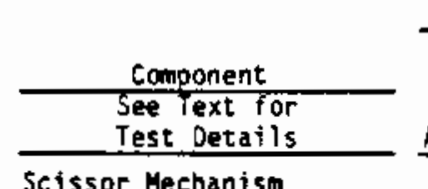

\begin{tabular}{c} 
Ease of \\
Baii \\
Alignment \\
\hline$\bullet$ \\
- \\
$x$ \\
0 \\
0 \\
.
\end{tabular}

Canister Access Port

Canister Grappie

Orive Hechanism

Drive Extension

Access Port Secondary

Seal Holder

Lifting Base for $5 e c$ ondary Seal Holder

Canister Liner

Load Cell jumper

Bellows Seal Holder

Oischarge Section Lid

Discharge Cone

Discharge Cone Insertion/ Removal Tool

40-Pin Instrument

Connect or/Jumper

Thermowe 1$\}$

Thermocouple Jumper

Thermocouple Manual Insertion

Removal of Jumper with

Bund le

In-melter Viewing

Melt Sampler Placement

Test Evaluation Criteria

In Canister

Melt Sampler Preinstalled

In Canister

Collection of Sample cup

$\begin{array}{lllll}\text { Visibie Impact } & \text { No } & \text { No } & \text { No } & \text { No Unusual } \\ \text { Bolts and Wrench Damage Potential "Hangup" Good Adequate Crane }\end{array}$

Ailgnment tngage Daring tor talse Hangup Good Adequate Crane

Dowels Muts Handling Seating Removal

Alignment Guides

$\bullet \bullet \bullet$

-

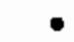

Guides Needed

Acceptable as tested.

O Marginal/requires further development.

$x$ Not applicable to this component. 
remote handling characteristics and accurate canister weight monjtoring. A mechanism for pulling and pushing the turntable along rails into position under the melter was tested and found to be both remotely operable and replaceable. The remote installation and removal of the turntable presented some difficulty, but is considered feasible based on the limited testing that was performed.

\section{MELTER DISCHARGE SECTION}

A mockup of a melter discharge section was constructed and used to simulate thermal conditions within a melter. Additionally, a prototype discharge section lid was incorporated in the mockup for thermal testing and also tested in conjunction with the melter shell for remote installation and air inleakage characteristics.

As a result of discharge mockup testing, lid-mounted heating elements were found capable of providing enough heat to maintain the metal trough and pour spout, as well as the upper portion of the discharge cone, well above the $1000^{\circ} \mathrm{C}$ minimum at discharge plenum temperatures of $1050^{\circ} \mathrm{C}$. An evaluation of the effect of element failure indicated that of the eight lid heating elements, any one of the four corner elements can fail and have little effect on trough temperatures, but the loss of any one of the four middle elements requires a substantial increase in power of the remaining elements to maintain trough temperatures. Normal lid element power level varies from $20 \mathrm{~kW}$ to $30 \mathrm{~kW}$. An air-cooled glass dan was found to operate at temperatures below $650^{\circ} \mathrm{C}$, thus preventing glass migration, at an air flow rate of $10 \mathrm{scfm}$. Power loss associated with the dam at this flow rate is $3 \mathrm{~kW}$. During testing, the cooling of pour spout temperatures through radiant heat transfer to a cold canister was found to be negligible. Turntable air inleakage above $3.0 \mathrm{scfm}$ was found to dramatically lower pour spout temperatures, requiring increased lid power levels (additional $4 \mathrm{~kW}$ at $8.5 \mathrm{scfm}$ ) to compensate.

The performance of the lid heating elements was also evaluated. PNLdesigned element contact clamps were found to operate at temperatures substantially higher than achievable using conventional hardware. Element contact surfaces modified by removing a manufacturer-applied spray coating and 
reapplying conductive metals using electroplating technique was found to lower contact temperatures, resulting in anticipated longer element lifetime. Element enclosures designed to minimize through-element inleakage were found capable of maintaining sufficiently low temperatures in the contact environment when left uncooled. When air or water cooled, temperatures were not lowered enough to warrant the complexity of remote coolant and exhaust lines.

The inleakage characteristics of two types of discharge lid gasket material were found to fit an orifice-type flow versus pressure drop equation, allowing the calculation of an "orifice" constant for each gasket. At -10 in. $\mathrm{H}_{2} \mathrm{O}$ melter vacuum, a $1 / 8-i n$.-thick flat gasket leaked at $130 \mathrm{scfh}$, while a 1-in.-dia. rope gasket leaked at $150 \mathrm{scfh}$.

The remote installation and removal of a discharge lid from a melter was verified using TV viewing and a remote crane and impact wrench. The relatively fragile lid elements survived several repititions of both lid installation and impact wrench vibration during lid tightening.

\section{DISCHARGE CONE}

A prototype melter discharge cone and handling equipment were designed, fabricated, and tested to determine their handling characteristics during remote installation and removal from the discharge section of a melter via the turntable system. The prototype discharge cone was installed and removed several times from the discharge section of a mock melter shell. The remote handling and operation of both the cone and cone removal equipment were verified.

\section{ELECTRICAL AND INSTRUMENT CONNECTORS}

A 40-pin instrument connector was built and mounted on a jumper to allow evaluation of the remote handling and installation of a muiti-pin jumper. The jumper was installed several times without difficulty using remote crane and viewing systems. Initial break-in of the connector was required to achieve good pin/socket alignment between the connector and the wall flange.

A 10-pin connector was built and connected to five thermocouples to evaluate thermcouple signal transmittance. Thermocouple signals were found to 
have a mean offset of $-0.237^{\circ} \mathrm{C}$. Over 400 measurements, temperature reading offset was found to be independent of both the number of times the connector is disconnected and the temperature being measured (from $25^{\circ} \mathrm{C}$ to $1050^{\circ} \mathrm{C}$ ). The instrument connector pins are thus well characterized and are suitable for remote instrument signal transmission.

A 20-pin $90 \mathrm{~A} / \mathrm{pin}$ connector was built and evaluated with respect to current carrying capacity. The pins were found capable of carrying $120 \mathrm{~A}$ at a safe pin temperature of $65^{\circ} \mathrm{C}$, and are thus capable of operating at $130 \%$ of their rated capacity. At $90 \mathrm{~A} / \mathrm{pin}$ operation, such a connector is predicted to generate $1.7 \mathrm{~kW}$ of heat, which may require air cooling.

A closed circuit TV signal connector, using instrument connector pins, was built and tested in conjunction with the melter viewing system. No radio frequency interference problems were encountered even though a coaxial (shielded) pin assembly was not used in the test connector. The TV signal transmittance was considered acceptable based on the quality of the transmitted signal as observed on a high resolution black and white monitor.

\section{THERMOCOUPLE REPLACEMENT SYSTEM}

A prototype thermocouple jumper system was designed, fabricated, and tested to determine its remote handling characteristics. The thermocouple jumper system consists of a thermocouple jumper, thermowell, and a simulated through-the-wall service sleeve. The in-cell portions of the test system were handled using the remote crane and viewing system. Acceptable remote handling of the system was verified.

\section{IN-MELTER VIEWING SYSTEM}

A camera and periscope system, developed for viewing the interior melting cavity of a melter, was installed and tested in an operating melter for over $1100 \mathrm{~h}$. During melter feeding, the condensed volatiles and entrained particles were prevented from obscuring the periscope aperture using a steamcleaning system provided on the periscope. The viewing system produced a sharp, clear picture throughout testing on a high resolution black and white monitor. A color synthesizer used in conjunction with the monitor was found to greatly enhance the visualization of details within the melting cavity. 
PRODUCT SAMPLING

A prototype glass melter sampler was built and tested to determine both its remote handling characteristics and the weight of glass it collects. Testing demonstrated that the sampler can be installed, operated, and retrieved remotely, but that detachment of the sample container into a portable cask is difficult although feasible using a remote crane and viewing system. Modifications are suggested to improve detachment of the sample cup. Under normal conditions the sampler was found to collect $97 \%$ by weight of its intended maximum amount of sample. When deliberately made to retract prior to complete filling, as may occur if a large glob of glass impacts the sample cup, a minimum sample weight of $42 \%$ is collected. Below this minimum weight, the sampler will automatically raise the sample cup back into the glass stream until a $97 \%$ of sample is collected. When fully retracted, the sampler is tucked unier the shoulder of the canister, far out of the path of the glass stream.

\section{MELTER NOZZLE MAINTENANCE SYSTEM}

Testing verified the ability of a prototype nozzle cleaner to clean out a melter nozzle clogged to a depth of $16 \mathrm{in}$. over $95 \%$ of the nozzle cross section with a tough, cast ceramic as the simulated blockage. Air cooling of the nozzle reamer bit, caused by inleakage of air around the bit when the melter is run at a vacuum, was found to provide sufficient bit cooling. The test apparatus was run at a vacuum of $-5 \mathrm{in}$. $\mathrm{H}_{2} \mathrm{O}$. Vacuum-induced air flow through the nozzle during cleaning was estimated as $18 \mathrm{scfm}$. Using water as a cooling medium at $1.5 \mathrm{gph}$ also resulted in trouble-free nozzle cleaning. The testing was done at room temperature $\left(25^{\circ} \mathrm{C}\right)$ and at melter plenum temperature $\left(700^{\circ} \mathrm{C}\right)$.

\section{LEVEL DETECTION SYSTEM}

A ${ }^{60}$ Co source mobilizing device was built and evaluated for remote handling and operation. Testing verified the device's remotability as acceptable. The testing of the device is reported even though a later change in the planned vitrification facility design allowed the use of a fixed, canisterlength ${ }^{60}$ Co source in place of a mobile source. 
Four low-temperature melting point metals were procured and evaluated for use in a sealing system. A lab-scale sealing system was designed to test the airtightness of a seal made using each of the four metals. All four metals were found capable of producing an adequate seal, although further tests are recommended to assess the corrosiveness of the metal in the liquid state. 


\section{CONTENTS}

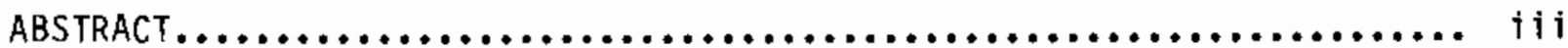

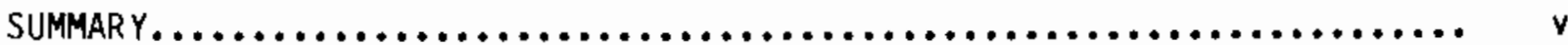

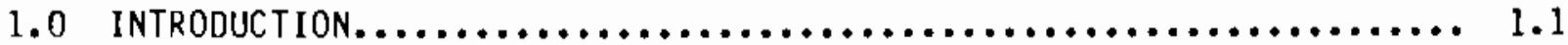

1.1 EqUIPMENT COMPONENT TESTING OBJECTIVES $\ldots \ldots \ldots \ldots \ldots \ldots \ldots \ldots \ldots \ldots$

1.2 VITRIFICATION SYSTEM DESCRIPTION.................... 1.2

1.3 COMPONENT TESTING............................... 1.5

2.0 CANISTER POSITIONINg TURNTABLE........................ 2.1

2.1 TEST EQUIPMENT................................ 2.2

2.2 TEST APPROACH................................ 2.9

2.3 RESULTS..................................... 2.11

2.3.1 Canister Handling and Access Port Sealing............ 2.11

2.3.2 Drive System............................ 2.12

2.3.3 Canister Weighing System...................... 2.12

2.3.4 Turntable/Melter Bellows Seal................... 2.13

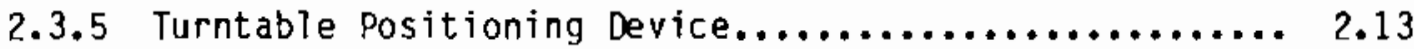

2.4 CONCLUSIONS................................... 2.13

2.5 RECOMMENDATIONS............................... 2.14

3.D MELTER DISChARGE SECTION............................. 3.1

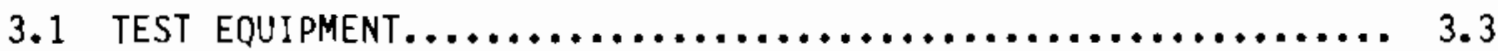

3.2 TEST APPROACH............................... 3.8

3.3 RESULTS....................................... 3.12

3.4 CONCLUSIONS..................................... 3.12

3.5 RECOMMENDATIONS................................. 3.14

4.0 DISCHARGE CONE.................................... 4.1 
Contents (cont'd)

4.1 TEST EqUIPMENT.............................. 4.4

4.2 TEST APPROACH $\ldots \ldots \ldots \ldots \ldots \ldots \ldots \ldots \ldots \ldots \ldots \ldots \ldots \ldots \ldots \ldots \ldots \ldots$

4.3 RESULTS $\ldots \ldots \ldots \ldots \ldots \ldots \ldots \ldots \ldots \ldots \ldots \ldots \ldots \ldots \ldots \ldots \ldots \ldots \ldots \ldots$

4.4 CONCLUSIONS $\ldots \ldots \ldots \ldots \ldots \ldots \ldots \ldots \ldots \ldots \ldots \ldots \ldots \ldots \ldots \ldots \ldots \ldots \ldots . \ldots \ldots$

4.5 RECOMMENDATIONS............................ 4.8

5.0 ElECTRICAL AND INSTRUMENT CONNECTORS $\ldots \ldots \ldots \ldots \ldots \ldots \ldots \ldots \ldots \ldots \ldots \ldots . \ldots \ldots$

5.1 TEST EqUIPMENT............................. 5.3

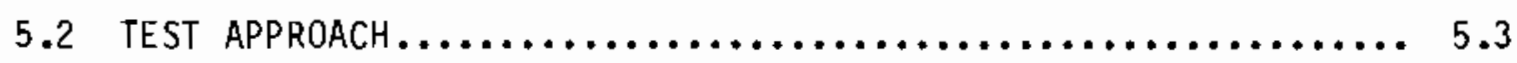

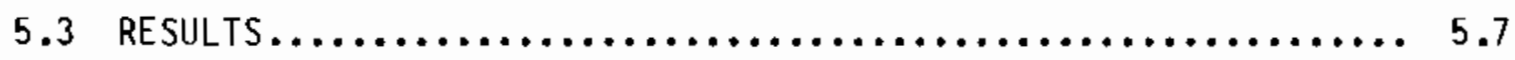

5.3.1 Remotability of 40-Pin Instrument Connector........ 5.7

5.3.2 Thermocouple Transmittance and Pin Wear

Resistance of Instrument Connector.............. 5.9

5.3.3 Ampacity of 20-Pin, 90 Amp per Pin Power Connector..... 5.15

5.3.4 Closed Circuit Television Signal Transmittance........ 5.21

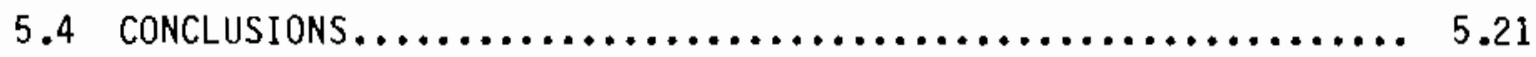

5.5 RECOMMENDATIONS............................. 5.22

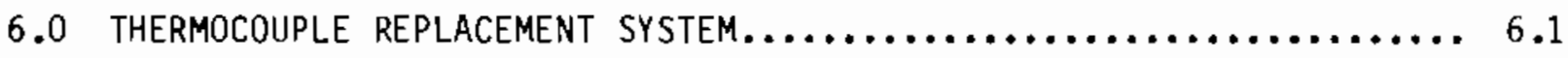

6.1 TEST EqUIPMENT $\ldots \ldots \ldots \ldots \ldots \ldots \ldots \ldots \ldots \ldots \ldots \ldots \ldots \ldots \ldots \ldots \ldots \ldots . . \ldots \ldots$

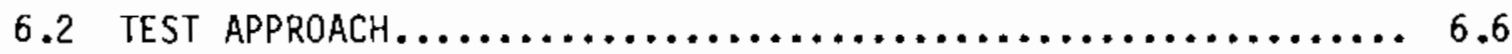

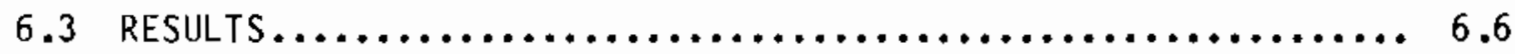

6.4 CONCLUSIONS ................................. 6.10

6.5 RECOMMENDATIONS .............................. 6.10

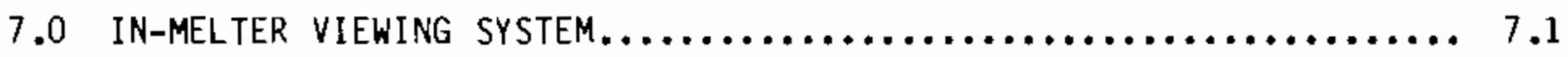

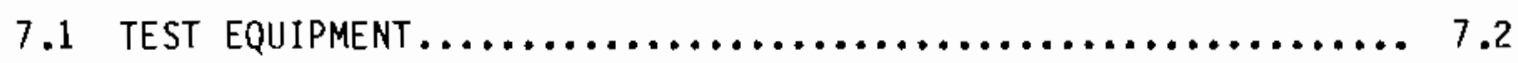

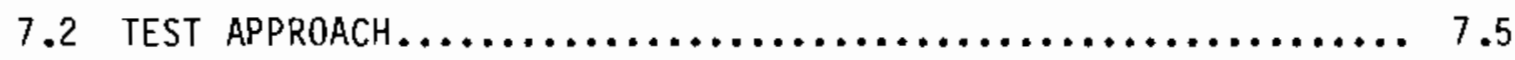

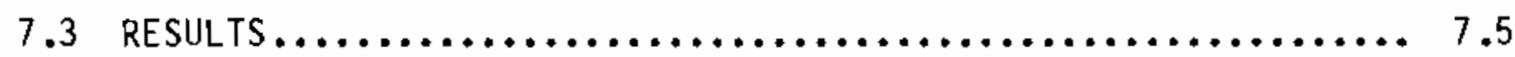


Contents (cont'd)

7.3 .1 0perability.............................. 7.6

7.3 .2 Camera Temperature........................ 7.7

7.4 CONCLUSIONS.................................. 7.8

7.5 RECOMMENDATIONS.............................. 7.8

8.0 GLASS SAMPLING................................... 8.1

8.1 TEST EDUIPMENT $\ldots \ldots \ldots \ldots \ldots \ldots \ldots \ldots \ldots \ldots \ldots \ldots \ldots \ldots \ldots \ldots \ldots \ldots \ldots$

8.2 TEST APPROACH............................... 8.3

8.3 RESULTS................................... 8.4

8.4 CONCLUSIDNS................................... 8.7

8.5 RECOMMENDATIONS............................... 8.9

9.0 MElter nozzle maintenance............................. 9.1

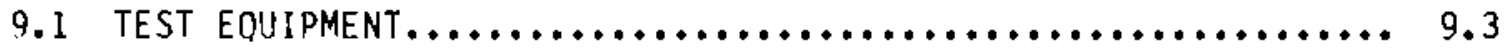

9.2 TEST APPROACH................................ 9.4

9.3 RESULTS.......................................... 9.4

9.3 .1 Air Cooling.............................. 9.4

9.3 .2 Water Cooling............................. 9.6

9.4 CONCLUSIONS................................. 9.7

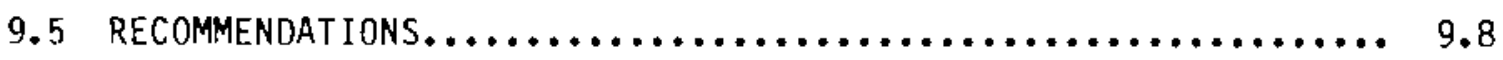

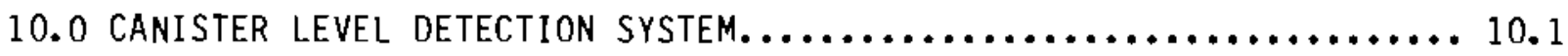

10.1 TEST EQUIPMENT............................... 10.2

10.2 TEST APPROACH................................... 10.3

10.3 RESULTS................................... 10.3

10.4 CONCLUSIONS.................................. 10.3

10.5 RECOMMENDATIONS............................. 10.5

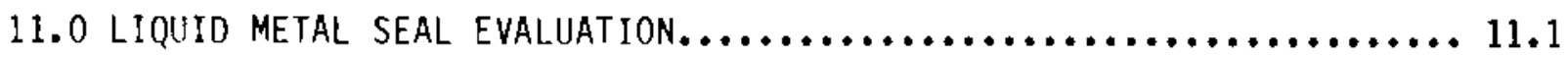

11.1 EQUIPMENT DESCRIPTION......................... 11.2 
Contents (cont'd)

11.2 APPROACH.......................................... 11.3

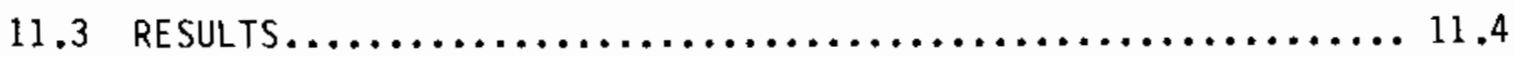

11.4 CONCLUSIONS......................................... 11.6

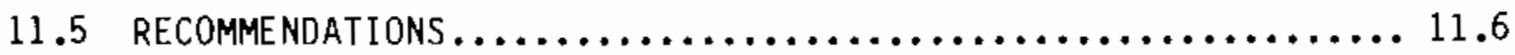

APPENDIX A - DETAILED RESULTS OF MELTER DISCHARGE SECTION TESTING....... A.1

APPENDIX B - VITRIFICATION PROCESS EQUIPMENT COMPONENT TESTING PLAN..... B. 1 


\section{FIGURES}

1-1 Manford Waste Vitrification Program - Process Flow Diagram....... 1.2

1-2 Schenatic of the Joule-Heated Ceramic Melter.................. 1.4

1-3 Overflow Section Mockup in Engineering Development Laboratory..... 1.7

1-4 Remote Test Facility................................ 1..8

1-5 Remote Television viewing System.......................... 1.9

1.6 Technician Operating the Remote Crane....................... 1.9

2-1 Canister Neck Flange and Canister Grapple................... 2..3

$2-2$ Canister Liner...................................... 2.3

2-3 Canister Access Port Seal System......................... 2.4

2-4 Seal Holder Installation on Canister Access Port............... 2.4

2-5 Tunntable Positioning Device.......................... 2.6

2-6 Turntable/Melter Discharge Port Bellows Seal................ 2.6

2-7 Assembled Bellows Seal System.......................... 2.7

2-8 Potentiometer Connected to the Drive Extension.............. 2.8

2-9 Pivoting Yoke Arm Assembly............................ 2.99

2-10 Load Cell Mounted on Turntable............................ 2.10

2-11 Modified Manford Electrical Connector...................... 2.10

3-1 Discharge Section of Melter Planned for HWVP................ 3.1

3-2 Mockup of Discharge Section.......................... 3.4

3-3 Melter Discharge Lid Prototype.......................... 3.5

3-4 Heating Elements Tested in the Prototype Discharge Lid......... 3.6

3-5 Hardware for Lid Element Electrical Connections................ 3.8

$4-1$ The Discharge Cone Assembiy.......................... 4.2

4-2 Discharge Cone Insertion Tool (A) with Cone (B) and with Removal Adapter Ring (C)..................................... 4.3 


\section{Figures (cont'd)}

4-3 Base Plate Holding and Removal Mechanism................... 4.5

4-4 Discharge Cone Mounted on Insertion Tool - Removal Mode......... 4.6

5-1 Remote Multi-Pin Connector Internal Isolation Plates Shown with Pins and Sockets......................................... 5.2

5-2 20-Pin Test Connector and Locations on Plate Used in Test....... 5.2

$5-3$ Test Jumper $. \ldots \ldots \ldots \ldots \ldots \ldots \ldots \ldots \ldots \ldots \ldots \ldots \ldots \ldots \ldots \ldots \ldots, 5.4$

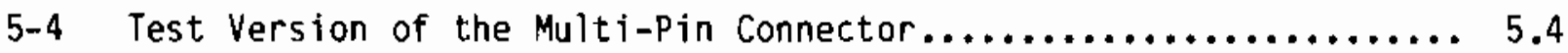

5-5 The 20 ea $\times$ 90-Amp Connector Test Apparatus................ 5.5

5-6 Television Signal Test Connector......................... 5.6

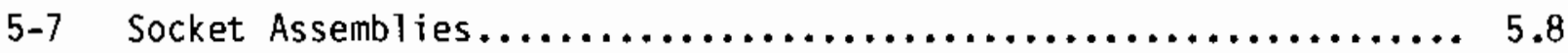

5-8 Number Frequency Oistribution of Thermocouple 0ffset Values...... 5.11

5-9 Pin Pair Temperature Data Plot.......................... 5.12

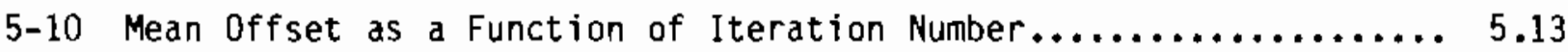

5-11 Mean 0ffset as a Function of Temperature Measured.............. 5.15

5-12 Mean 0ffset as a Function of Iteration at Constant Temperature.... 5.16

5-13 Pin Pair No. 3 Temperature Oata Plot........................ 5.16

5-14 Pin Resistance, Pin Power Loss, and Connector Temperature as

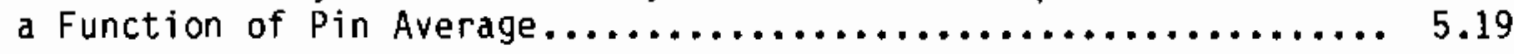

5-15 Internal View of Upper Connector with wires Installed........... 5.20

6-1 Thermocouple Jumper Test Assembly $\ldots \ldots \ldots \ldots \ldots \ldots \ldots \ldots \ldots \ldots, 6.2$

6-2 Thermocouple Jumper Assembly $\ldots \ldots \ldots \ldots \ldots \ldots \ldots \ldots \ldots \ldots \ldots \ldots, 6.2$

$6-3$ Thermocouple Jumper $\ldots \ldots \ldots \ldots \ldots \ldots \ldots \ldots \ldots \ldots \ldots \ldots \ldots \ldots \ldots, 6.4$

6-4 Thermowell Section........................................ 6.4

6-5 Through-The-Wall Thermocouple Jumper Assembly................ 6.5

6-6 Thermowell Removal $\ldots \ldots \ldots \ldots \ldots \ldots \ldots \ldots \ldots \ldots \ldots \ldots \ldots \ldots \ldots, 6.8$

$6-7$ Thermocouple Jumper Installation........................ 6.9

6-8 Impact Wrench on Thermocouple Jumper...................... 6.10 
Figures (cont'd)

6 -9 Thermocouple Jumper Removal........................... 6.11

7-1 Melter viewing System Components and Cooling Air Flow.......... 7.3

7-2 Adjustable Iris Showing Open and Closed Positions............. 7.4

7-3 End Cap of Periscope Before Installation................... 7.4

7-4 Encrustation of Condensed Off-Gas Chemical on Cooled Tip

8-1 Sampler With Lifting Yoke and Crane Hook.................... 8..2

8-2 Sequential Positions of Sampler......................... 8.2

8-3 A Sampler Installation into Empty Canister Using Crane and Lifting Yoke....................................... 8.5

8-4 Top view of Canister Containing Remotely Installed Sampler....... 8.6

8-5 Loading of Canister into Turntable With Sampler Pre-Installed..... 8.7

8-6 Lowering Sampler into Sample Retainer/Transport Cask........... 8.8

8-7 Recommended Sampler Modifications........................ 8.10

$9-1$ Meiter fozzle Cleaner................................ 9.2

$9-2$ Nozzle Cleaner Test Stand............................... 9..3

$9-3$ Blockage Core Removed from Test Stand..................... 9.6

9-4 Nozzle Inner Diameter After Function as a Function of Location.... 9.7

$10-1$ In-Cel1 ${ }^{60}$ Co Source Positioning Device..................... 10.2

$10-2{ }^{60} \mathrm{Co}$ Source Positioning Device......................... 10.4

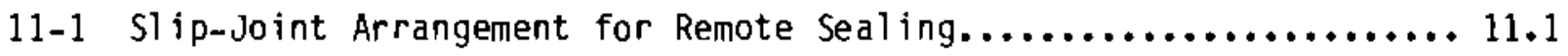

11-2 Metal Containment Seal Test Apparatus..................... 11.4

A-1 Discharge Section Lid Installed on Melter Shell..................

A-2 The Lid is Positioned Above the Melter by Remote Control......... A.2

A-3 Dowel Ends from Lid are Inserted in Guide Tubes on Melter......... A.2

A-4 Guide Dowels on Melter Flange are Lined up with Receiving Holes on Lid................................................ 
Figures (cont'd)

A-5 Lid is in Place on Melter and the Impact Wrench is Being Lowered to Tighten Nuts, which Completes Installation.....................

A-6 Internal Temperature During Steady State Operation............ A.6

A-7 Discharge Mockup Energy Balances....................... A.6

A-8 HWV Dimensions and Refactory Materials used for Heat Loss

Calculations........................................ A.9

A-9 Thermal Mockup Dimensions and Refactory Materials used for Heat Loss Calculations...................................... A.9

A-10 Thermocouple Locations on Cooling Dam of Thermal Mockup Unit...... A.10

A-11 Dam Temperatures versus Dam Air Flow and Plenum Temperature....... A.11

A-12 Discharge Trough and Glass Path Temperatures as a Function of Air Inleakage.................................... A.12

A-13 Required Power Increase as a Function of Rate of Air Inleakage.... A.13

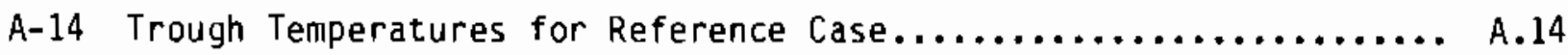

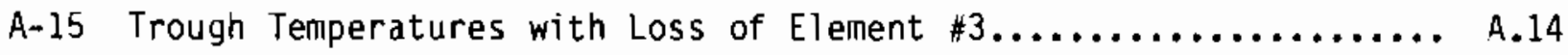

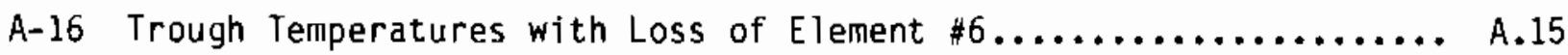

A-17 Trough Temperatures with Loss of Elements $\sharp 3$ and $\sharp 4 \ldots \ldots \ldots \ldots \ldots$..........

A-18 Trough Temperatures with Loss of Elements $\$ 3$ and $\# 5, \ldots \ldots \ldots \ldots \ldots$ A.17

A-19 Trough Temperatures with Loss of Elements $\$ 6$ and $\# 8 \ldots \ldots \ldots \ldots \ldots$...........

A-20 Trough Temperatures with Loss of Elements $\# 1$ and $\# 2 \ldots \ldots \ldots \ldots . . .$. A.18

A-21 Discharge Section Heating Element Resistance versus Temperature... A.20

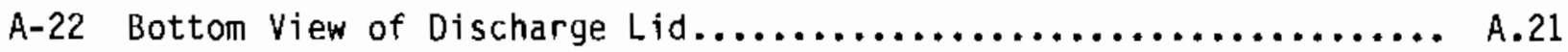

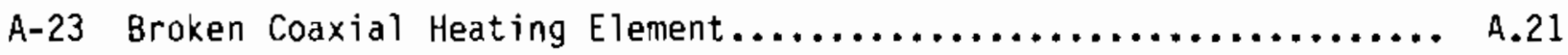

A-24 Comparison of Element Contact Temperatures................. A.23

A-25 High Temperature Element Contact Performance Data ............ A.25

A-26 Effect of Presence of Cold Canister on Pour Spout Temperature..... A.26

A-27 Cooled Heating Element Contact Enclosure Performance Data........ A.27

A-28 Garlock and Rope Gaskets on Melter Shell Flange.................28 
Figures (cont'd)

A-29 Combined Air Inleakage Through Garlock Lid Gasket and Cooled Covers............................................. A.30

A-30 Air Inleakage Through Garlock Lid Gasket Only................. A.30

A-31 Combined Air Inleakage Through Ceramic Rope Gasket and Cooled Covers........................................... A.32

A-32 Characterization of Lid Gasket Inleakage.................. A.33

A-33 Discharge Section Lid Shown After Testing................... A.35

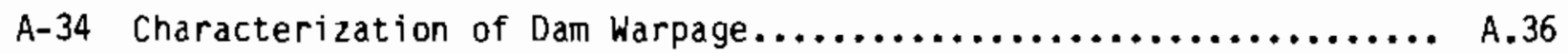




\section{$\underline{\text { TABLES }}$}

5-1 Multi-Pin Instrument Connector Thermocouple Data............. 5.10

$5-2$ Mean Offset as a Function of Iteration Number............... 5.13

5-3 Mean Offset as a Function of Temperature Measured............. 5.14

5-4 Mean offset as a Function of Connector Pin................. 5.15

5-5 Pin Resistance, Power Generation, and Temperature Data......... 5.18

5-6 Pin Resistance and Loss versus Anperage................... 5.20

9-1 Cutting Edge Temperature with Air Cooling................... 9.5

11-1 Composition of Metals Used in Preliminary Testing............. 11.3

11-2 Metal Seal Test Observations.......................... 11.5

A-1 Thermal Mockup and HWVP Discharge Heat Transfer Quantities....... A.9

A-2 Calculated and Predicted Discharge Section Energy Balance........ A.10

A-3 Heating Element Resistance Data........................ A.19

A-4 Comparison of Element Power and Temperature Date.............. A.22

A-5 Chenical Analyses................................. A.37 


\subsection{INTRODUCTION}

A large volume of radioactive waste in the form of solutions and sludges is in interim storage on the Hanford Site. This waste slurry was generated during reprocessing of spent nuclear fuel and subsequent waste treatment. The Department of Energy (DOE) has sponsored research over the past 25 years that would develop methods to reduce stored waste volume and produce waste forms suitable for permanent disposal. The Pacific Northwest Laboratory (PNL) has developed technology for incorporation of waste into borosilicate glass through a vitrification process. The Hanford Waste Vitrification Program then conducted a comprehensive, remote testing program, which would provide assurance that the equipment required for vitrification of radioactive waste could be safely and efficiently operated in the planned Hanford Waste Vitrification Plant. Figure $1-1$ is a process flow diagram of the planned vitrification system.

This document describes the equipment components and the testing program, and gives test results, conclusions, and recommendations.

\subsection{EQUIPMENT COMPONENT TESTING OBJECTIVES}

The objective of equipment component testing for the Hanford Waste Vitrification Program is to design and test remotely operable and maintainable equipment to enable operation of the vitrification process in a remotely operated, canyon-type facility. In the planned remote canyon facility, existing technology developed at Hanford and Sayannah River Plant are used to the extent possible, but in various applications, particularly around and in the ceramic glass melter, new equipment concepts have to be provided and verified to make the process viable. The equipment development is being performed by PNL for Rockwell Hanford Operations, the Project Manager and Plant Operator for this Department of Energy (DOE) project.

Equipment concepts developed and tested include:

- Turntable (canister handling under melter)

- Melter Discharge Section

- Melter Discharge Cone (remotable glass pouring channel from melter) 


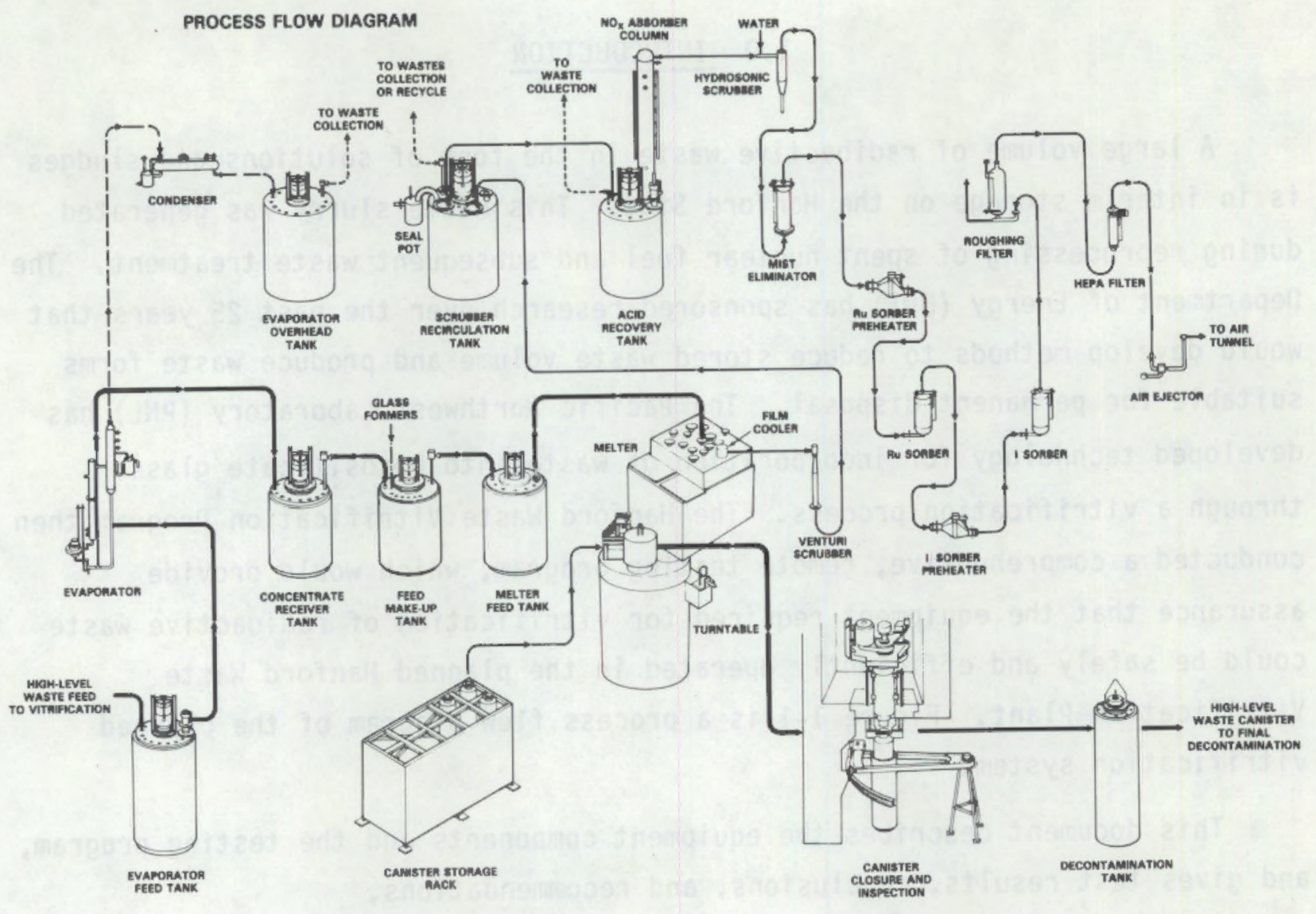

FIGURE 1-1. Hanford Waste Vitrification Program - Process Flow Diagram

- Electrical and Instrument Connectors - Assess SRL Design

- Through-The-Wall Thermocouple Connector

- In-Melter Viewing - Assess SRL Design

- Melter Glass Sampler

- Melter Nozzle Cleaner

Also, a brief test was conducted to select a liquid metal for use as a sealant between two pieces of equipment. For reference, the vitrification process equipment component testing plan, prepared prior to testing, is provided in Appendix B.

\subsection{VITRIFICATION SYSTEM DESCRIPTION}

The new equipment developed in Component Testing for the Hanford Waste Vitrification Plant is involved with various aspects of the Liquid-Fed Ceramic 
Melter (LFCM) operation. The LFCM is a relatively old equipment concept that has not yet been operated in a remote canyon facility. The requirements for remote operability and maintainability, together with various process functions, provided the need for new equipment features. Developing these features were the objective of the Component Testing Program. The LFCM process and equipment is described below to provide the context of the test program.

The LFCM process converts a slurry feed containing, radioactive wastes and glass-forming chemicals, to a vitrified (glass) product in a metal canister. In the Hanford vitrification process, the waste slurry feed is concentrated to the greatest extent possible so that it can still be transferred from tank to tank. The glass forming chemicals are added as frit or chemical constituents in the waste feed makeup tank and blended to a homogeneous slurry. This slurry is transferred from the feed makeup tank to the feed tank where it is pumped at a controlled rate to the melter.

In the melter, the feed enters through a cooled nozzle in the melter top and falls onto the cold cap. The water is evaporated off, and other chemical constituents may be decomposed to oxides in the cold cap. The off gas at about $300^{\circ} \mathrm{C}$, consisting primarily of steam, is vented through the off-gas system. The melter is normally operated at from -1 to $-10 \mathrm{in}$. of water. The solids in the cold cap are converted into a homogeneous molten state in the melter liquid pool at about $1150^{\circ} \mathrm{C}$.

To remove the molten glass from the main melter cavity, the glass is airlifted from the main cavity bottom into a trough in the overflow section of the melter. In the overflow section the glass flows down the trough and over a pour spout. From the pour spout the glass drops down in to a canister, located under the lip where it is allowed to cool. The overflow section must be maintained above $1000^{\circ} \mathrm{C}$ to maintain the glass in a flowable state and is maintained at a vacuum relative to the cell. The melter system must be maintained at a vacuum relative to the cell for contamination control; and air inleakage needs to be minimized to control heat consumption and off-gas handling requirements.

The LFCM is a joule-heated ceramic-lined cavity, which is contained in a cooled metal shell. A schematic of the melter is shown in Figure 1-2. Two 


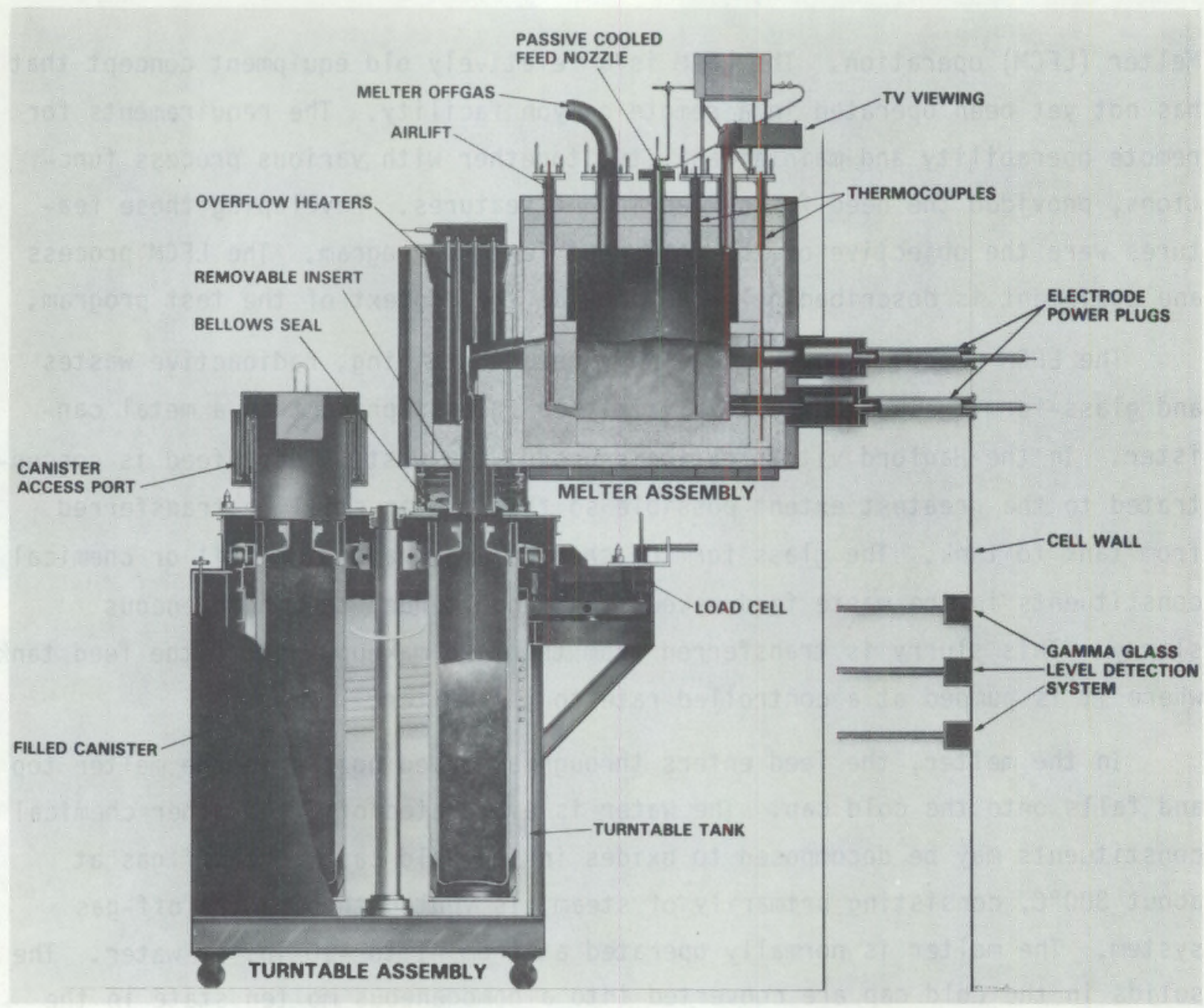

FIGURE 1-2. Schematic of the Joule-Heated Ceramic Melter

pairs of side-entering Inconel 690 electrodes are provided for supply power to the melter. The melter cavity is lined with from one to four layers of ceramic for glass containment and thermal insulation. The overflow section contains a trough in a cavity that is also ceramic lined. The overflow section is heated with up to eight resistance rod heaters suspended from the section ceiling. The melter cavity and overflow section is contained in a $304 \mathrm{~L}$ SS shell that is water cooled. The water cooling minimizes the heat loss to the cell and provides a further barrier to any potential for molten 
glass migration. Melter instrumentation and services, except for the main cavity power electrodes, are provided through penetrations in the melter roof ceramic, using remote flanges or nozzles for connections. To assist maintaining vacuum control in the melter, the melter is connected to the turntable with a bellows seal. The turntable is a sealed carousel which provides for handling the canister under the melter.

\subsection{COMPONENT TESTING}

To make the LFCM a viable system for operation in a remote canyon facility, several components required development and testing as described below.

- Turntable - This unit is required for positioning the canisters under the melter, control of process ventilation during canister filling and canister cooldown, and providing cooling for just-filled canisters.

- Melter Discharge (Overflow) Section - Features of the discharge section that were developed and tested include: a) removal and installation of the lid heater assembly from the melter, b) a method for installing heating elements on the heater assembly to minimize air inleakage, c) determine optimum locations of thermocouple to facilitate operational control, d) determine air inleakage for various sealing methods, and e) observe section component integrity during operation.

- Melter Discharge Cone - During glass pouring, the glass stream may wander and stick to the walls of the overflow section, thus causing a plug. The melter discharge cone lines this flow pathway such that should a plug occur, the plug can be cleared by remote removal and replacement of the cone.

- Electrical and Instrument Connectors - There are a variety of electrical power requirements and instrument connections which require remote operation and maintenance. Savannah River Laboratory (SRL) had developed a modified Hanford electrical connector to perform the required services. This connector was tested to verify its performance in this program for supplying power to the melter overflow section, heaters, and various instrument signals. 
- Through-The-Wall Themocouple Connection - A concept was developed to allow shielded thermocouples to extend continuously from the melter cavity out through the cell facility wall for connections to readouts and instrumentation. The system was tested to assure acceptable attributes.

- In-Melter Viewing - To control melter operation, it is necessary to view the melt surface. A remotely operated and maintained TV system was developed and tested in this function. The unit developed incorporates features previously developed by SRL personnel.

- Glass Sampler - To periodically verify glass quality being produced by the melter a remote sampler was developed to take samples from the glass stream as it is pouring into the canister.

- Nozzle Cleaner - Off gas from the melter contains entrained particulates which tend to plate out on and plug the melter off-gas port. A remotely operated and maintained system is needed to periodically clean out this nozzle. A power-driven reamer was developed for this purpose.

- Bellows Seal - A concept was also developed for sealing the turntable to the melter using a liquid metal seal.

All of the tests were perofrmed in the 324 Building in the Hanford 300 Area. The overflow section and associated electrical connector tests were performed in the Engineering Development Laboratory (EDL) shown in Figure 1-3. The remote operation and maintenance tests were performed in the High-Bay Extension (HBE).

A remote operations test facility, Figure 1-4, was constructed in the HBE to facilitate testing. This test facility has a variable speed remotely operated 5-ton bridge crane. The crane is radio controlled and has a motor-driven rotary hook similar to the Hanford canyon cranes. Test activities could be viewed directly or through a remote TV viewing system, Figure 1-5. Two remotely operated TV cameras were located on the crane bridge. The cameras could travel along the bridge to the desired viewing positions. The cameras had the capability of pan, tilt, and zoom lens. A technician operating a remote crane handling system is shown in Figure 1-6. 


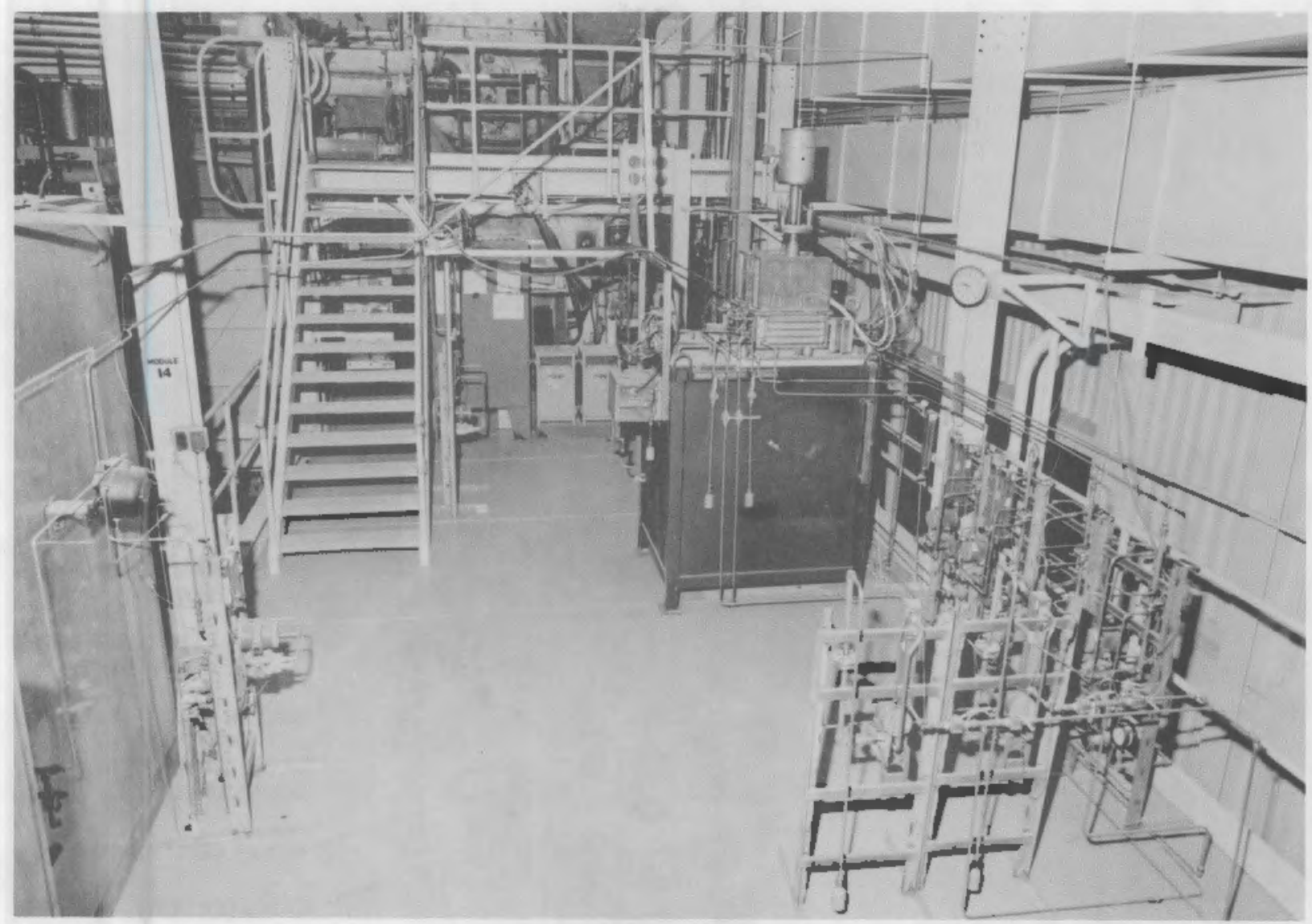

FIGURE 1-3. Overflow Section Mockup in Engineering Development Laboratory 


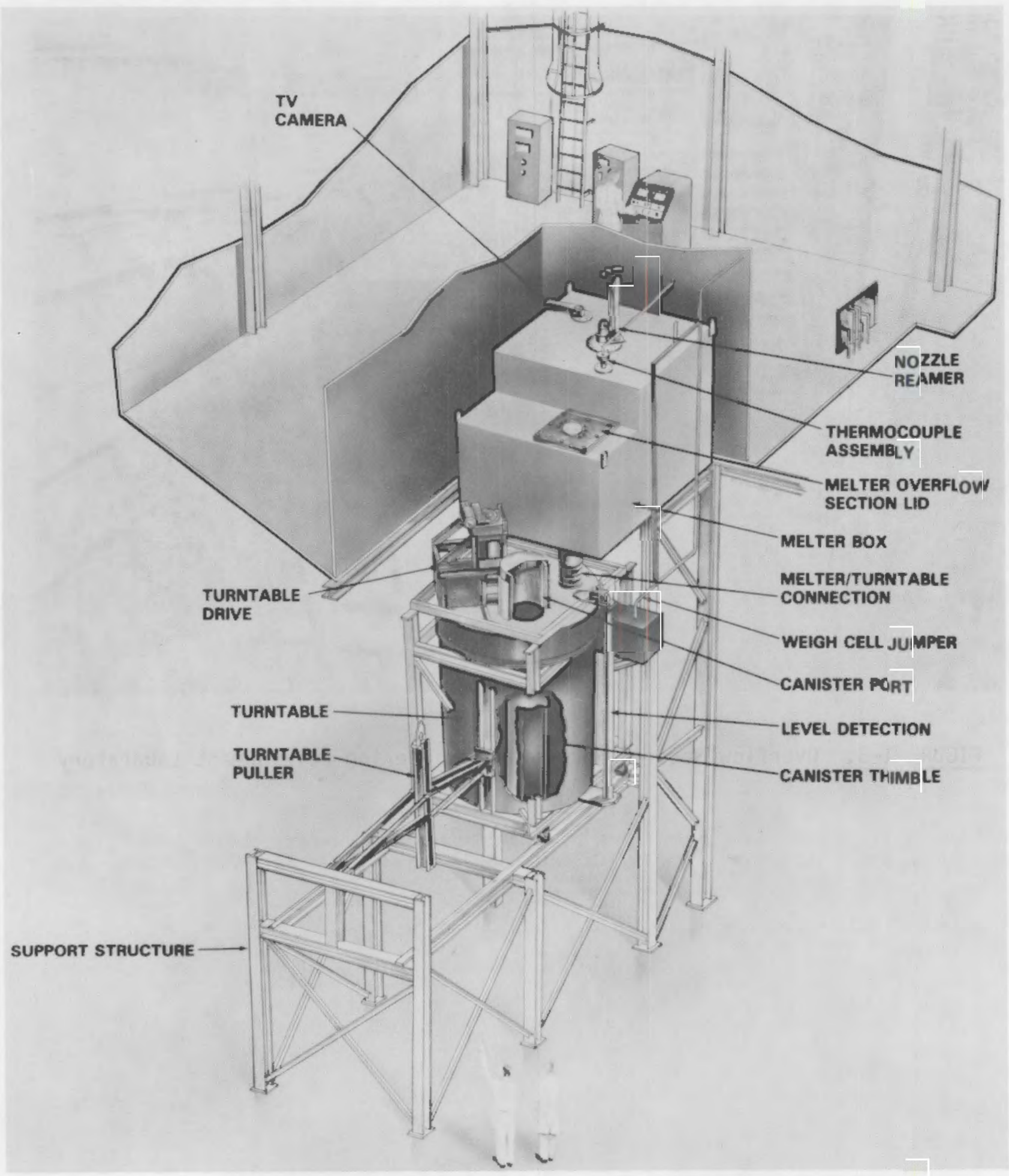

FIGURE 1-4. Remote Test Facility 


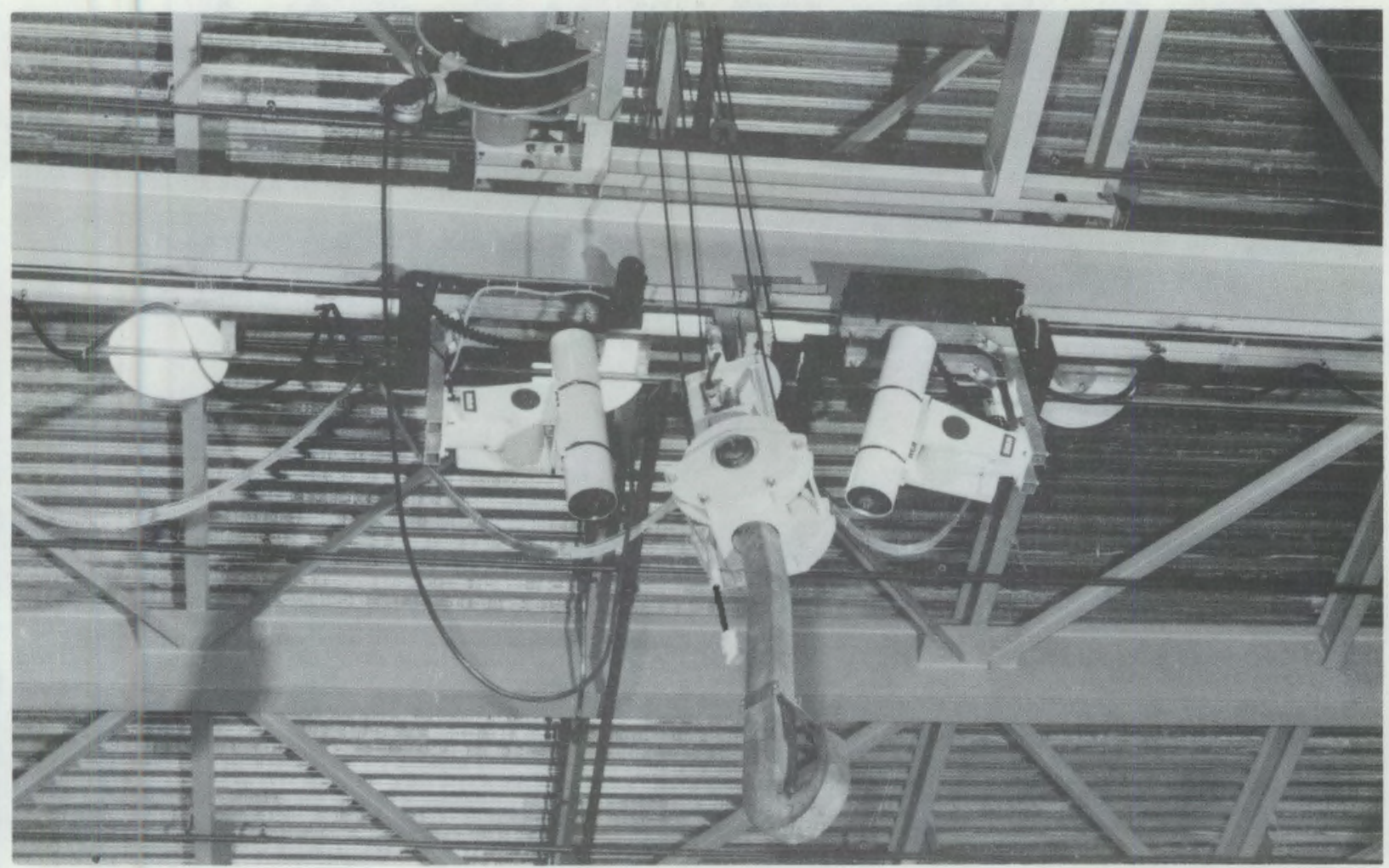

FIGURE 1-5. Remote Television Viewing System

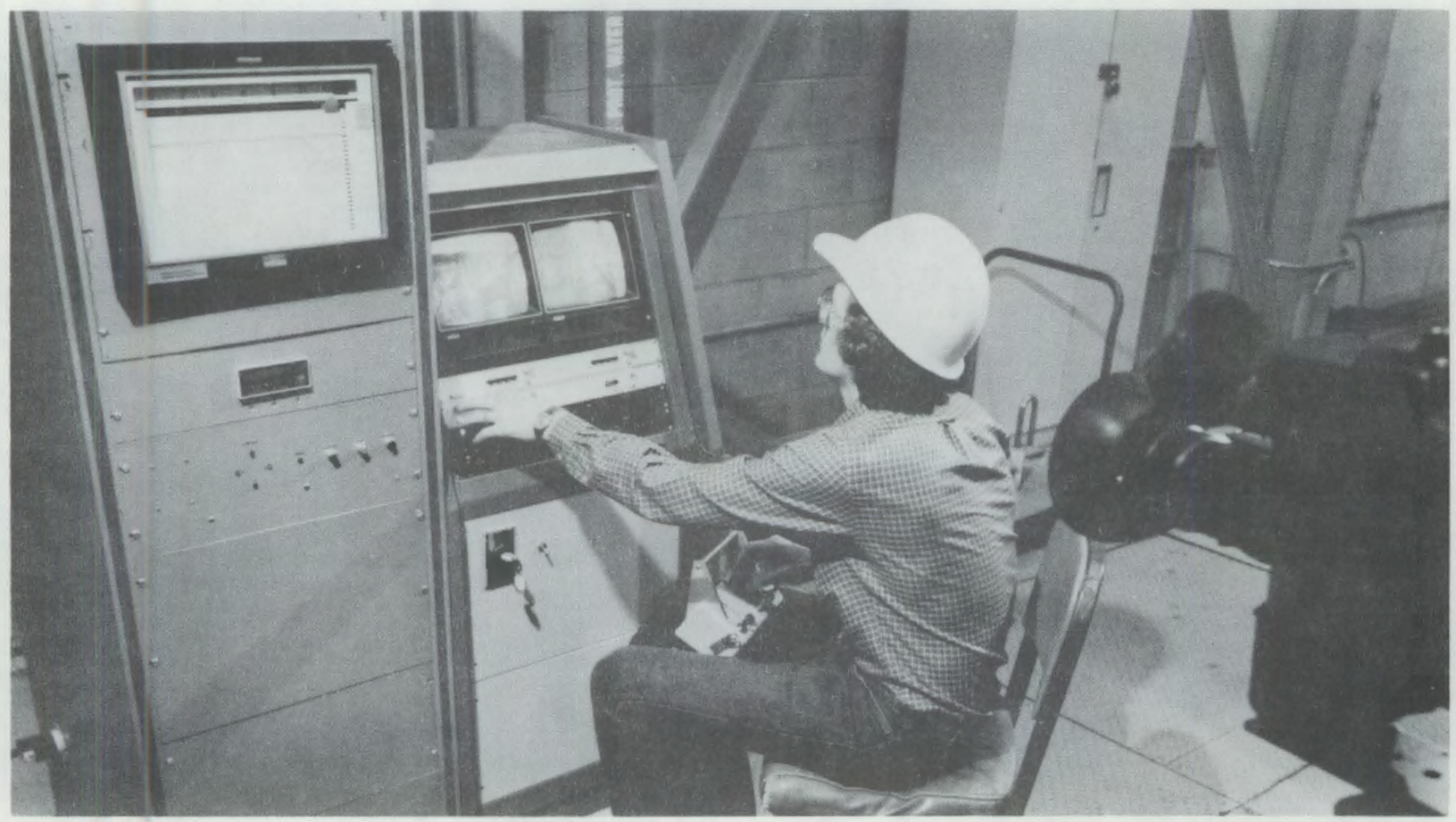

FIGURE 1-6. Technician 0perating the Remote Crane 
:

-

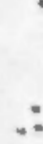

$-$

$\therefore$

;

"

,

$-$ 


\subsection{CANISTER POSITIONING TURNTABLE}

Metal canisters are used to collect the molten glass as it is drained from the melter. A turntable is used to position the empty canisters below the melter pour spout where the molten glass pours out of the melter. When full, the canister is rotated away from the pour spout and allowed to cool. After each canister is filled and allowed to cool, it is lifted out of the turntable through an access port and replaced with an empty canister.

The turntable consists of a rotating rack that supports four canisters in a water-filled tank. The turntable rack is rotated in $90^{\circ}$ increments to provide access to each canister position, first for placing an empty canister into the turntable, second for positioning the canister under the pour spout for filling, third for controlled cooling, and fourth for final cooling. When moved to the original position under the access port, the filled canister is removed and replaced with an empty canister. The canisters are held within thimbles supported by yokes attached to a central rotating drive shaft. Thimble liners are required for three reasons. First, if the glass overflows into the liner, the liner and canister can be removed as a unit. Second, if the interior of a liner becomes excessively contaminated, the liner can be replaced. Third, if the liner is damaged during canister handling operations, it can be replaced.

An electrical powered indexer drive system is used to rotate the turntable rack in precise $90^{\circ}$ increments. A mechanical cam indexing drive system and an electrical feedback potentiometer indexing system were developed and tested for indicating and assuring canister positioning.

The test turntable contains a canister access port and a melter overflow discharge port. Since the melter will be operated at a vacuum, air inleakage through these ports must be minimized. Sealing systems that can be remotely installed and operated were developed and tested for both ports.

A canister-weighing system, consisting of a strain gauge load cell mounted on a remote jumper, was developed and tested. The purpose of the system is to monitor canister filling operations by continuously weighing a canister while it is being filled with molten glass. 
All remote handling aspects of the turntable were tested. These tests included positioning the turntable under the melter; installing the drive system, indexing system, port sealing mechanisms, and canister weighing system; and handling the canisters and thimble liners.

\subsection{TEST EQUIPMENT}

A full-scale, operational turntable system (shown earlier in Figure 1-4) was built and tested. The test turntable is an enclosed tank $8^{\prime} 0^{\prime \prime}$ in dia $x$ $10^{\prime} 3^{\prime \prime}$ tall in which two full-scale canisters in canister liners were supported and rotated. For remote simulation, a full-scale melter shell, consisting of an $8^{\prime} 6^{\prime \prime} \times g^{\prime} 0^{\prime \prime} \times 8^{\prime} 1^{\prime \prime}$ empty metal box with remote flanges was provided. The turntable and melter shell are positioned relative to each other as planned for in-cell installation.

One of the two ports on top of the turntable is a $2^{\prime} 7^{\prime \prime}$-dia canister access port. Using an overhead crane and a grapple device, canisters can be lowered into and removed from the turntable through this port. The grapple device fits over a flange on the canister neck. This flange has two flat sides, $180^{\circ}$ apart, as shown in Figure 2-1. Inside the grapple are two similarly shaped, semi-round lifting surfaces. The grapple is lowered onto the canister flange and rotated until the grapple lifting surfaces fall past the canister flange flat surfaces. The grapple is then rotated $90^{\circ}$ to engage the lifting surfaces, allowing the grapple to grasp the flange and lift the canister out of the turntable. After an empty canister is installed in the turntable, the grapple is rotated $90^{\circ}$ in the opposite direction where it can be lifted clear of the canister flange. Figure 2-2 is a photograph of a canister liner.

The canister access port contains interior and exterior sealing devices analogous to an airlock. The exterior seal is made by a cover whose sides fit into an annular water-filled gap between two vertical cylinders lining the canister access port. The removal of this access cover activates an interior sealing mechanism that creates a seal between the inner wall of the access port and the top flange of a canister liner as shown in Figure 2-3. The interior sealing mechanism consists of an "E" seal, an "E" seal holder and 

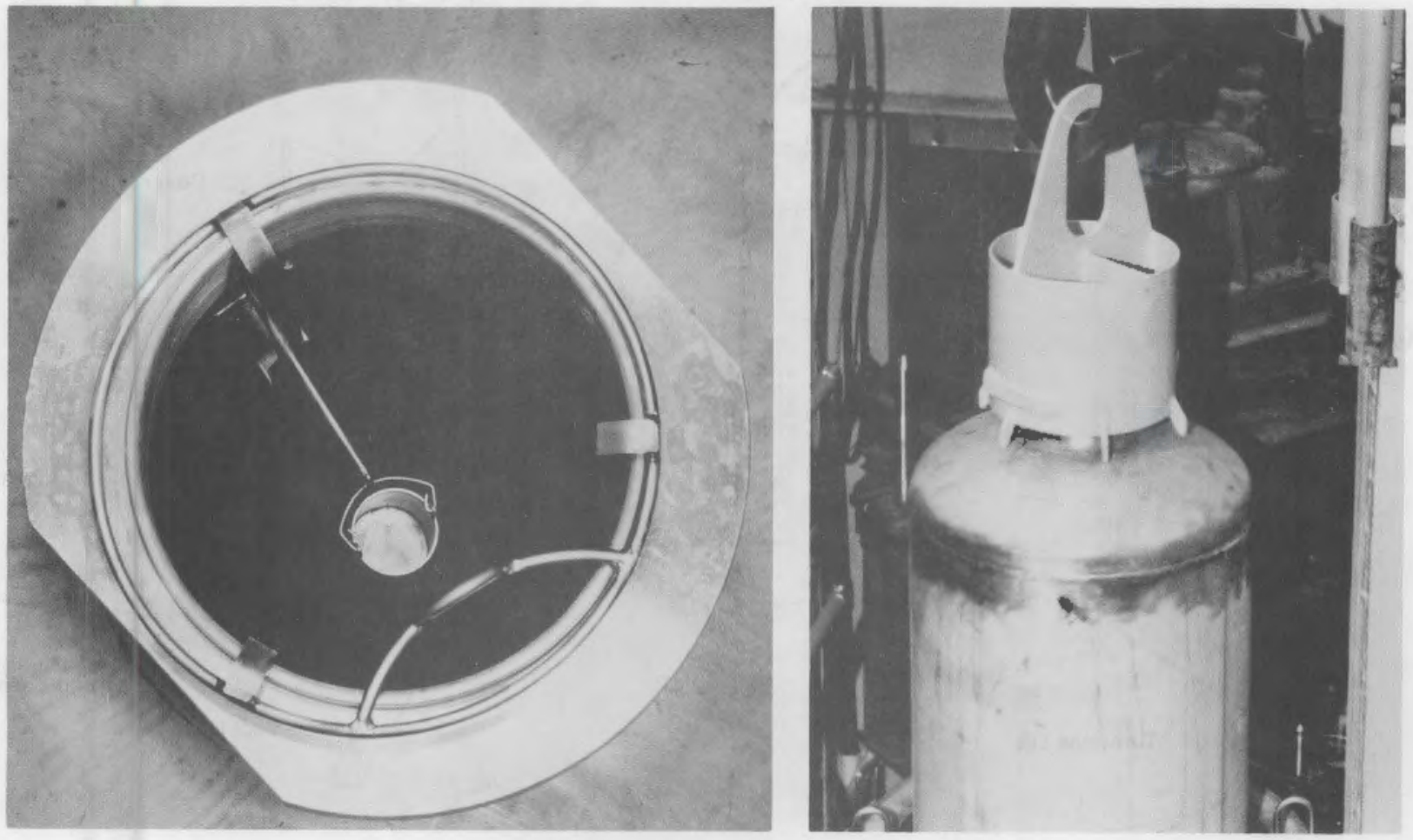

FIGURE 2-1. Canister Neck Flange and Canister Grapple

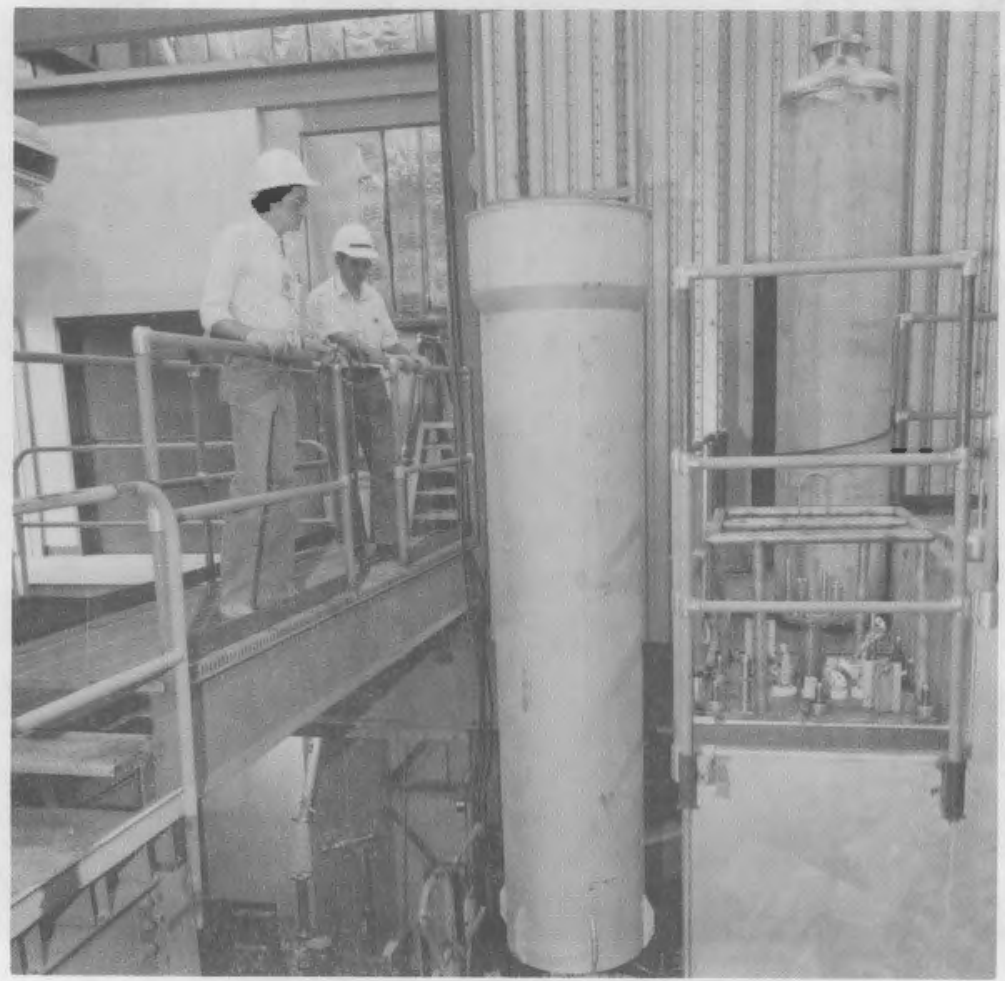

FIGURE 2-2. Canister Liner 


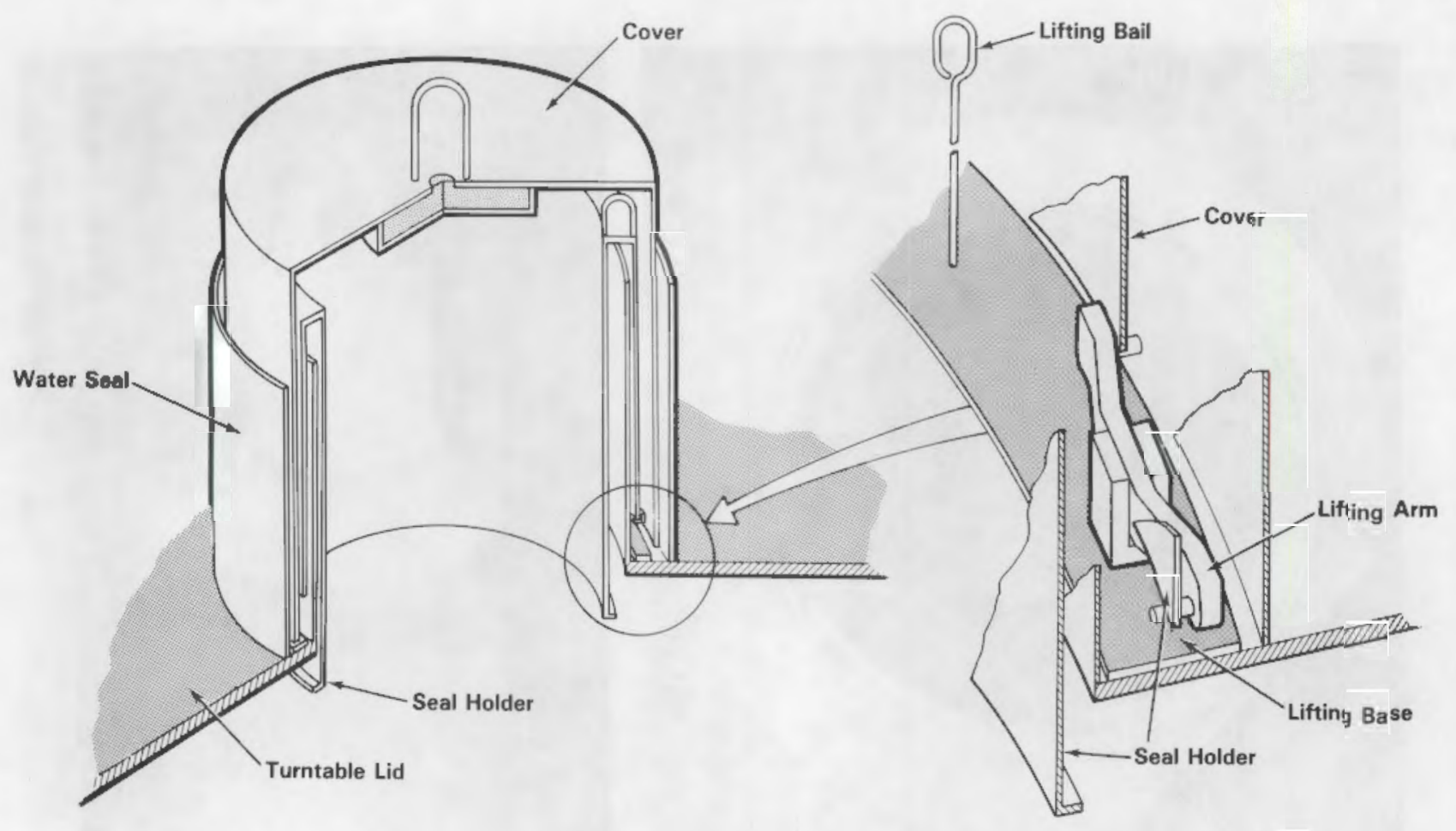

FIGURE 2-3. Canister Access Port Seal System

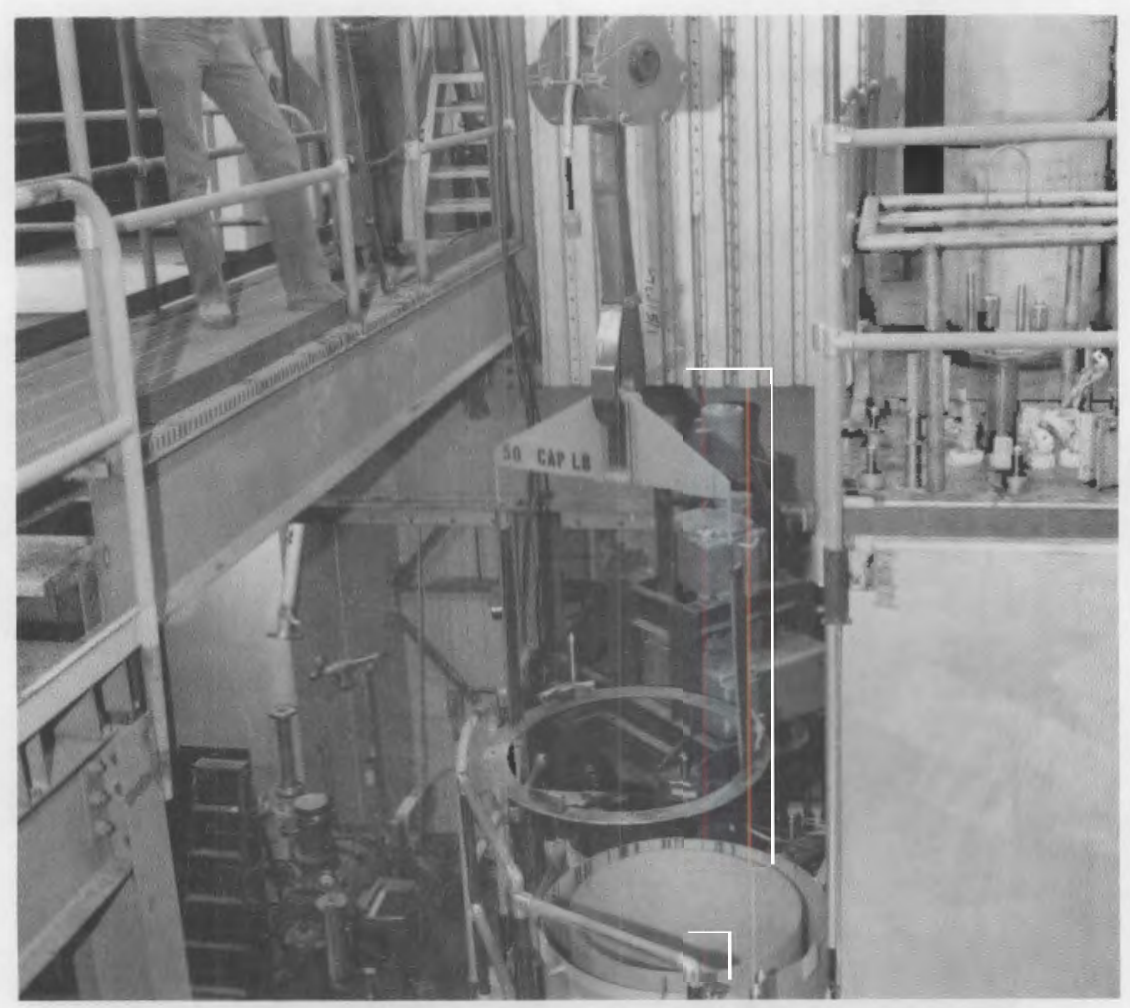

FIGURE 2-4. Seal Holder Installation on Canister Access Port 
a seal-holder lifting base with pivot arms that contact the access port cover. Figure 2-4 shows the seal holder being installed in the access port. The "E" seal is a highly flexible metal seal with a cross-section shaped like an $\Sigma$, having a compression value of $4 \mathrm{lb} /$ circumferential inch. When the access cover is opened, the "E" seal is compressed by the weight of the seal holder on the flange of the canister liner, creating a near airtight seal. When the access cover is closed, the lower edge of the cover forces the pivot arms downward, which raises the seal holder and thus the "E" seal away from the liner flange. With the liner flange free, the turntable can be advanced unobstructed while the exterior water seal prevents air inleakage. The "E" seal was not available for testing because the manufacturer was unable to fabricate the seal to the specifications required.

The second of the two ports on top of the test turntable is the discharge port that is aligned with a similar port on the bottom of the discharge section of the melter. The glass flows from the melter pour spout through these discharge ports into a canister. The melter and turntable discharge ports are aligned by moving the turntable along a rail on the support structure until the turntable is at the correct position under the melter. For servicing, the turntable can be pulled out from under the melter along the rails using a scissors jack mechanism that is driven by an impact wrench. The mechanism, shown in Figure 2-5, is designed to be remotely installed and removed.

The melter discharge port is connected to the turntable with an inflatable bellows mechanism. This mechanism consists of an inner and outer metal bellows welded to upper and lower flanges (Figure 2-6). The annular space between the inner and outer bellows is pressurized with compressed air, causing the upper flange to extend up and mate with the flange on the melter discharge port. A metallic "E" seal gasket with a loading rate of $201 \mathrm{~b} /$ circumferential inch is used between the mating. flanges. The inner bellows is Inconel 625 to provide the necessary corrosion-resistant properties that will be encountered in an actual melter operation. The outer bellows is made from 321 stainless steel (SS). The flanges are made of 304 SS. The "E" seal is fabricated from Inconel 718. Inflation air for the bellows is supplied through a 1/2-in. SS tube, through the lower flange. Figure 2-7 shows the assembled bellows seal system. 


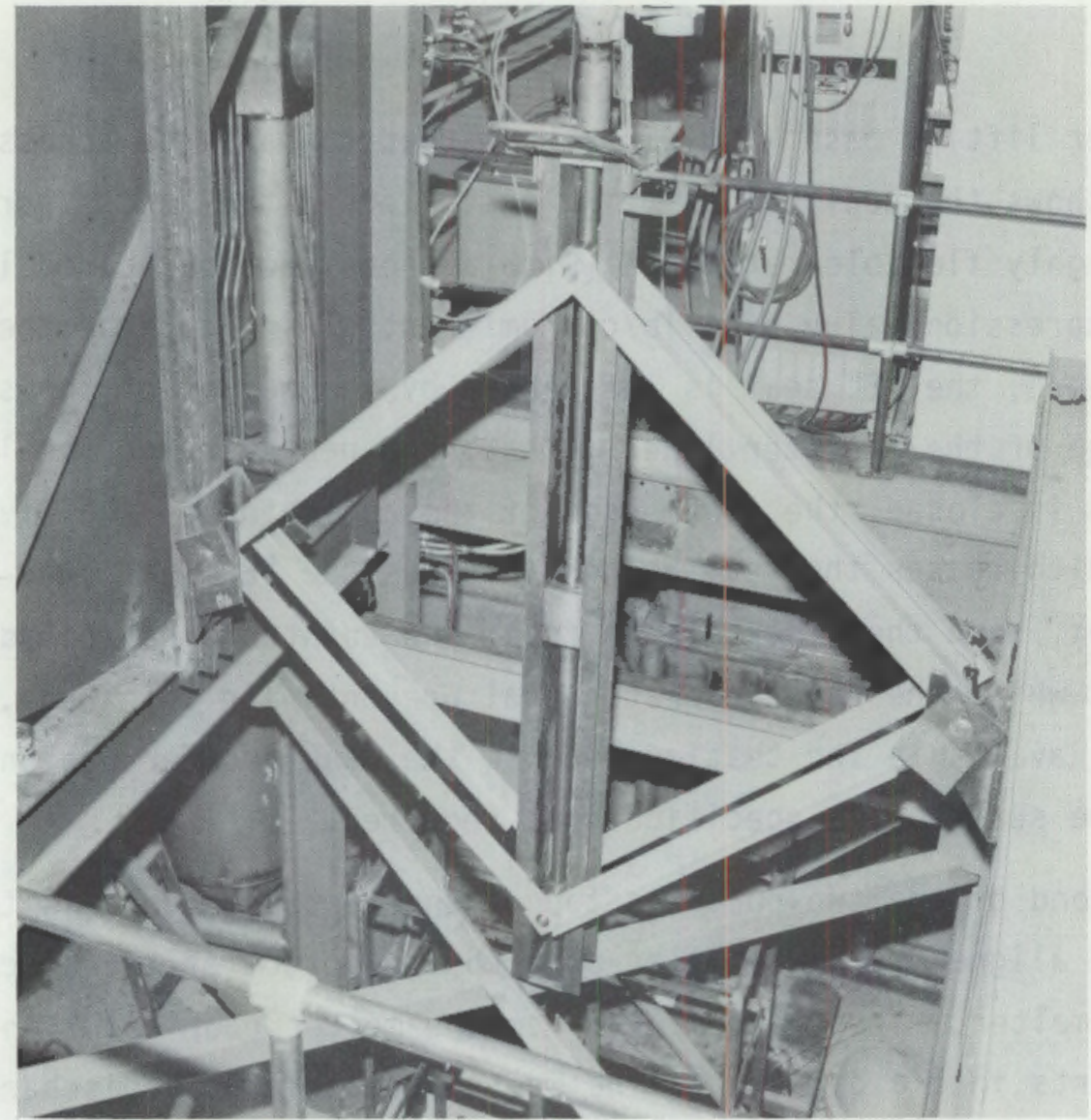

FIGURE 2-5. Turntable Positioning Device

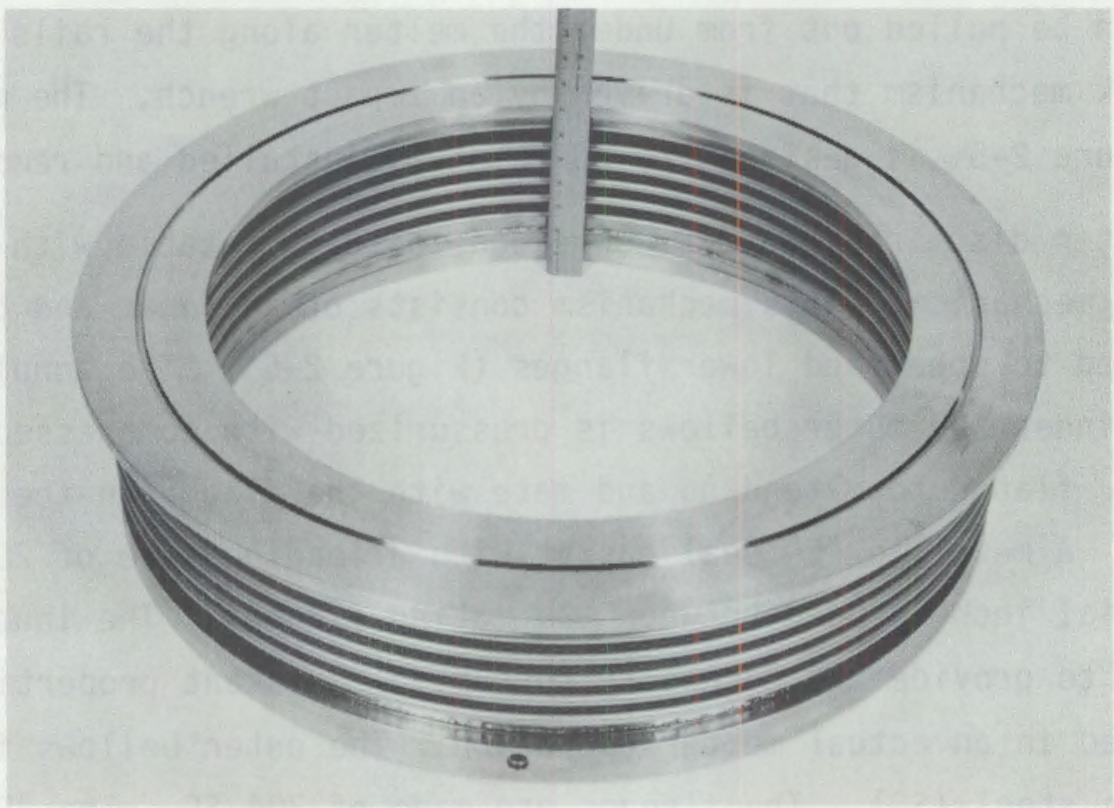

FIGURE 2-6. Turntable/Melter Discharge Port Bellows Seal 


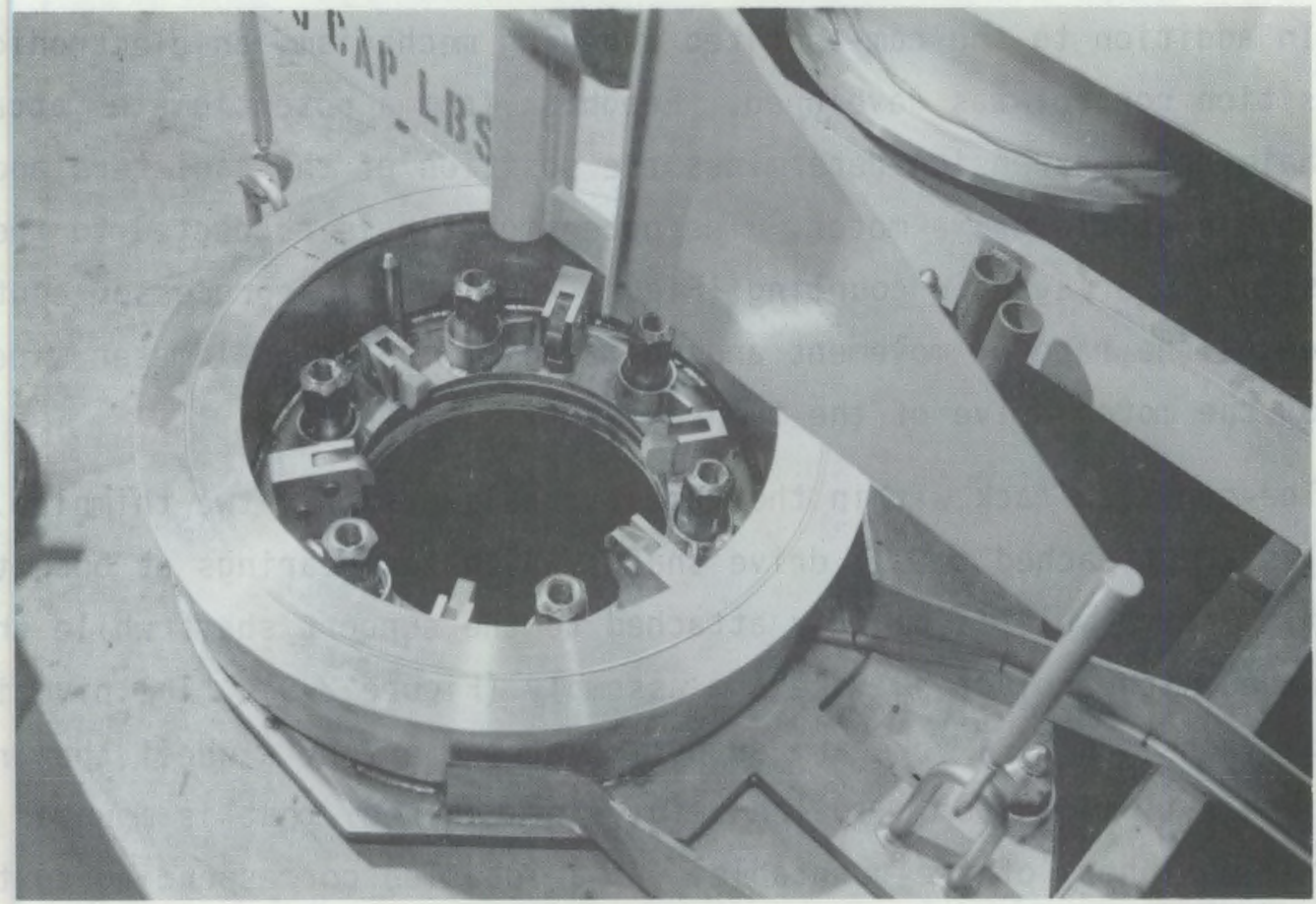

FIGURE 2-7. Assembled Bellows Seal System

When canisters are loaded into the turntable through the access port and the access cover is in place, they can be rotated to the desired location within the turntable. This rotation is accomplished by action of a center drive shaft connected to the canister rack. Rotational force for the drive shaft is provided by a four-position cam-operated indexer. Power to the indexer is supplied by a 1-hp electric motor. A gear reducer is used to attain the desired rotational speed of $1 / 4 \mathrm{rpm}$. A chain drive extension mechanism is used to connect the output of the indexer to the turnable drive shaft. A cam-operated indexing mechanism is used to detect and assure the correct positioning of the canisters. The mechanism combines a 15-sec dead time between mechanical movements with an electrical limit switch that interrupts power to the drive motor to achieve smooth starts and stops and assures the required accuracy. The indexing mechanism is protected by a slip clutch that contains an assymetrical arrangement of five spring-loaded plungers. If the preset torque limit of $32,000 \mathrm{in.-1bs}$ is reached, the plungers will 1 ift out of their sockets and remove all stress to the indexing mechanism. A full revolution is required for automatic reengagement of the plungers and sockets. 
In addition to the cam-operated indexing mechanism, an electronic system of position control was developed. Feedback from a potentiometer attached to the chain drive extension determines the position of the canisters and controls the electric drive motor. The potentiometer is connected to the drive extension via a magnetic coupling (Figure 2-8). A microprocessor control system senses the rate of movement and position of the potentiometer wiper arm to control the motor drive of the turntable.

The canister rack within the test turnable has only two thimbles. These thimbles are attached to the drive shaft, which has bearings at both top and bottom. One thimble is rigidly attached to the support shaft while the other is mounted with a pivoting yoke arm assembly (Figure 2-9). The pivoting assembly consists of a yoke arm supported at one end by a wheel that rides on a support rail made from a rolled 8 -in. steel channel that is mounted on the interior periphery of the turntable. At a location corresponding to the melter overflow, there is a $3-i n$. gap in the rail. Located in this gap is a 3-in.-long pad connected to a pivot beam that transmits force to an area where

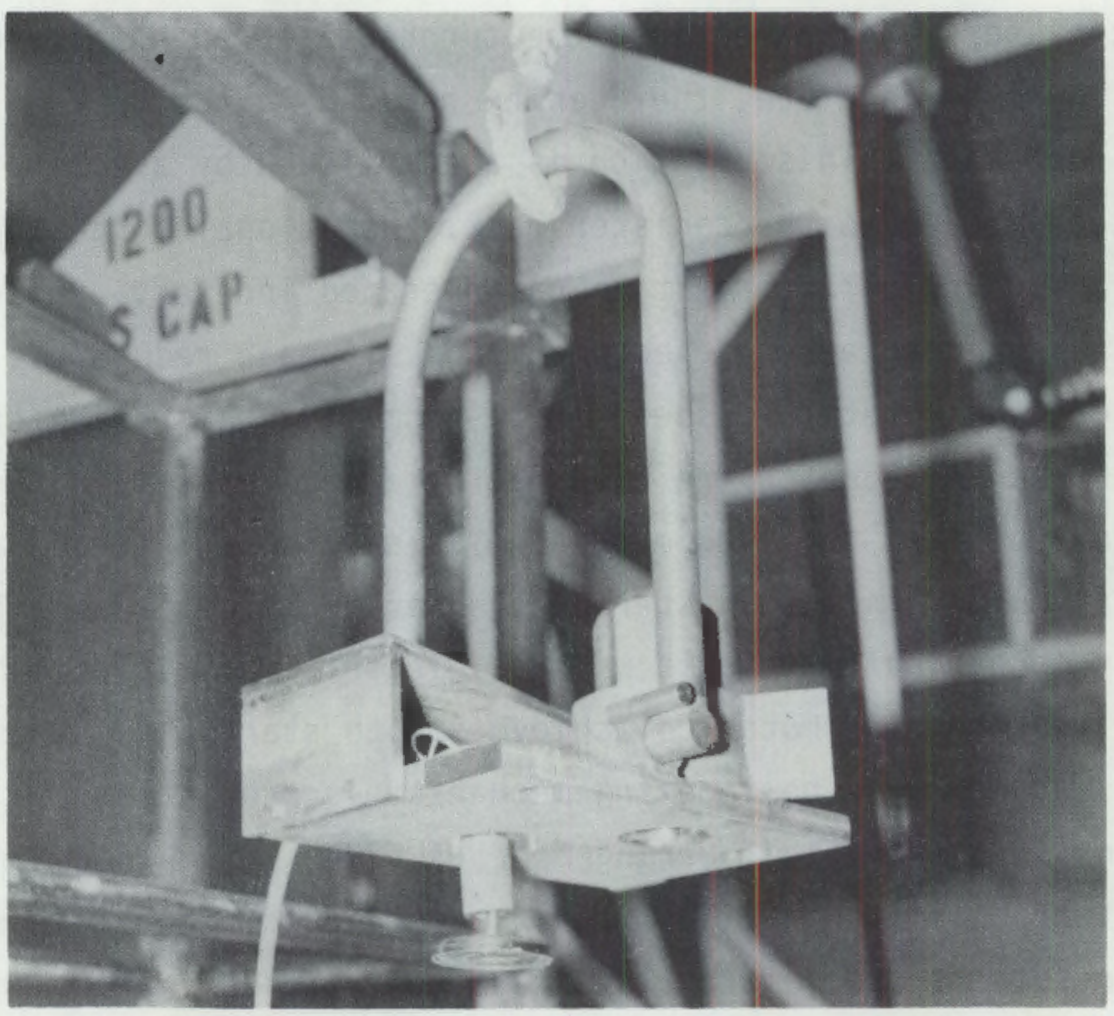

FIGURE 2-8. Potentiometer Connected to the Drive Extension 


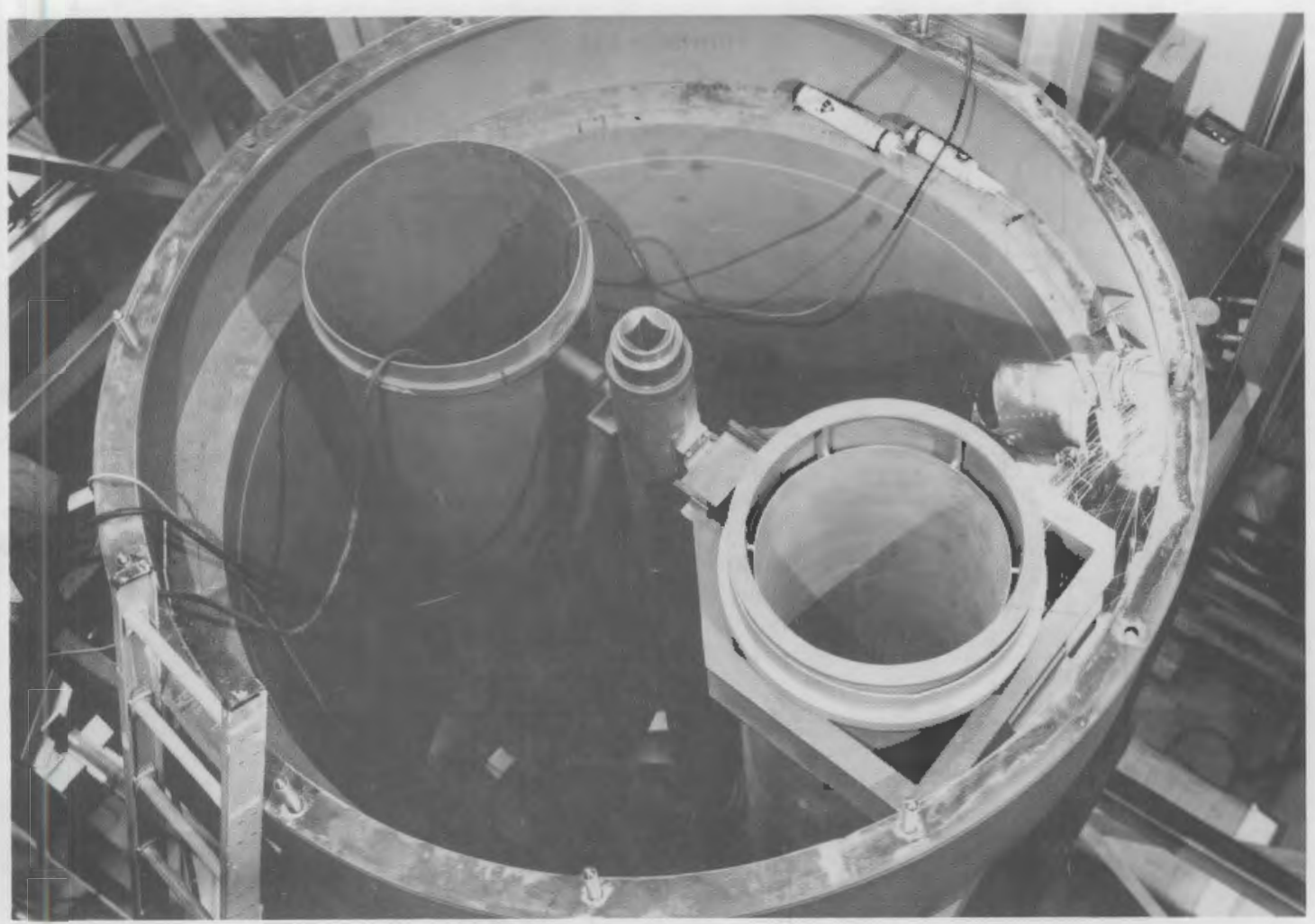

FIGURE 2-9. Pivoting Yoke Arm Assembly

remote installation of a load cell is feasible. With pivoting yoke assembly half of the canister the load is carried by the central shaft and the other half is transmitted to the load cell via the pivot beam. The load cell is a compressive strain gage that interfaces directly with the pivot beam. The load cell is mounted on a jumper that is installed on the turntable with three remote nuts (Figure 2-10). The other end of the jumper is a modified Hanford electrical connector (Figure 2-11) through which the load cell signal is passed to a readout in the operating gallery. The signal from the load cell can also be used as a backup for position indication.

\subsection{TEST APPROACH}

The purpose of the turntable testing effort was to assess the feasibility of remotely installing, operating, and maintaining a canister-positioning turntable system. 


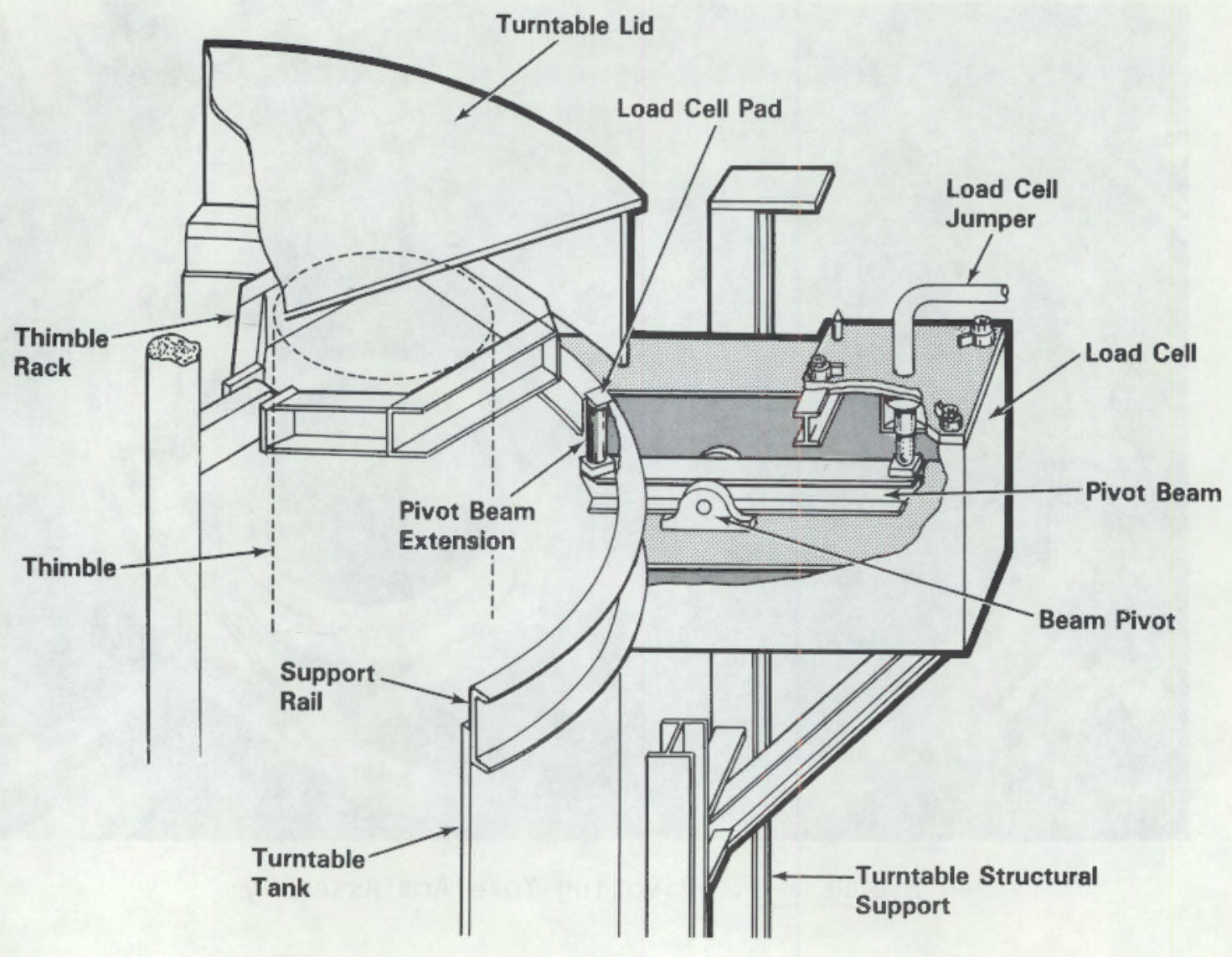

FIGURE 2-10. Load Cell Mounted on Turntable

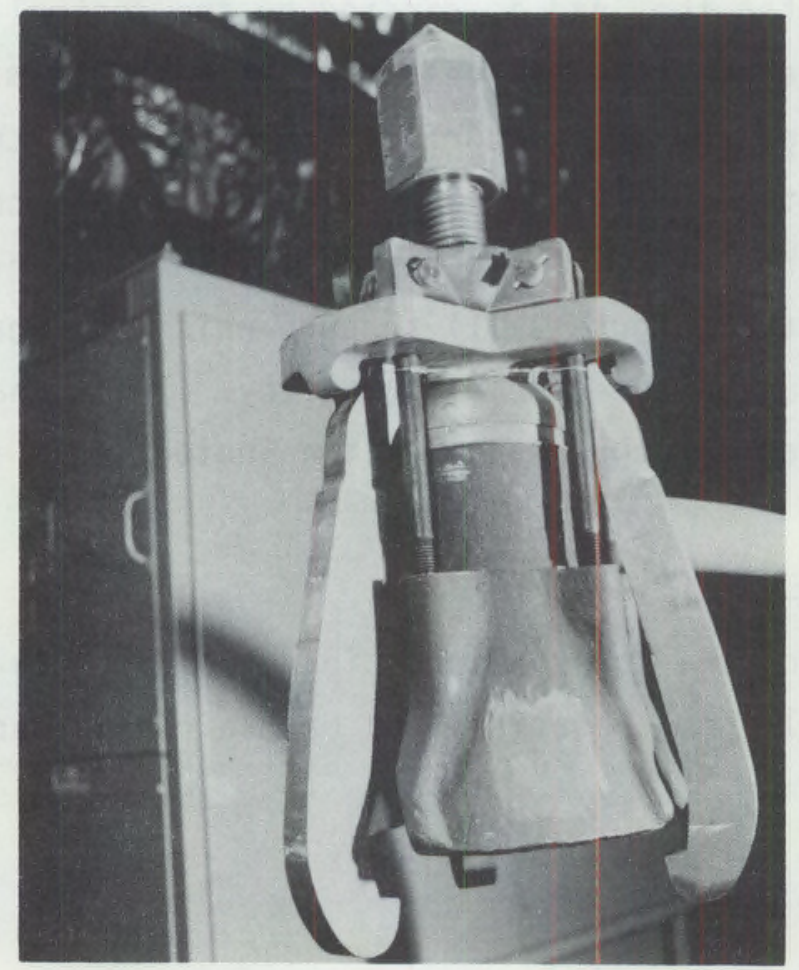

FIGURE 2-11. Modified Hanford Electrical Connector 
Testing of the turntable was performed in three phases. During the first phase the canister access hatch was tested both for remotability and operability. This was performed by remotely removing the canister hatch cover, canister, seal holder, lifting base, and liner. These components were then reinstalled on the turntable in the reverse order. This process was repeated a total of six times, three times in each thimble of the turntable.

During the second phase, operability and remotability of the turntable drive and the load cell were tested. The turntable drive was tested for consistency of canister placement. Accuracy of positioning was measured by installing cross hairs on the thimbles centerlines and suspending a plumb bob in the center of both the access hatch and melter discharge openings. The load cell was tested by incremental additions of water to a canister. The canister was rotated off between each addition of water, then rotated back onto the load cell so that the increased canister weight was sensed by the load cell. The remote aspects of these units were verified by multiple removal and installation utilizing the crane and impact wrench in the Remote Test Facility.

The third phase of testing covered the bellows seal connection between the turntable and melter shell. For this test the bellows seal was installed on top of the turntable and then isolated, with respect to internal atmosphere, from both the melter shell and turntable. The bellows was then inflated to pressures ranging from 40 psig through 90 psig. Following inflation, a vacuum was applied to the bellows cavity and the resulting air inleakage was measured. The vacuum applied was $5,10,15$, and $20 \mathrm{in}$. of water. Following the air inleakage test, the bellows seal assembly was tested for remotability.

\subsection{RESULTS}

\subsubsection{Canister Handling and Access Port Sealing}

The access hatch cover, as designed, was found to have a center of gravity that was too high for easy installation. The center of gravity was lowered; installation and removal were easily accomplished. 
Engagement of the canister grapple to the canister revealed that there was insufficient clearance provided between the flange of the canister and the engagement slots in the grapple. After the grapple was connected to the canister, the removal and installation of the canister from the turntable worked well. Disengagement of the grapple from the canister was also difficult due to the limited clearances.

The seal holder was easily removed from the hatch area using the lifting yoke. When the unit was installed, the bottom surface came in contact with the lifting ears of the lifting base about $75 \%$ of the time. This contact ranged from a slight touch to a hard jar. As a result, a seal would have been damaged during remote installation.

The lifting base for the seal holder was easily removed and installed into the water seal annulus of the hatch assembly.

Some difficulty was encountered when remotely engaging the canister liner lifting yoke with the liner bails. Dnce engaged, the canister liner was easily removed and installed in the thimble. Difficulty with engagement of the lifting yoke was due to space limitations in the liner and the obstructed view of the liner bails.

\subsubsection{Drive System}

Over the course of the test, which lasted for 85 revolutions, the accuracy of the drive fluctuated by only $1 / 4 \mathrm{in}$. During removal of the drive mechanism from the top of the turntable, it was found that freeing the residual torque of the drive shaft allowed the drive unit to be lifted off easily. This was also true of the drive extension. When the units were reinstalled, a side pull had to be exerted on both the drive extension and drive mechanism to achieve proper alignment.

\subsubsection{Canister Weighing System}

During testing of the canister, weighing water was added to a canister in the pivoting yoke arm thimble after every 10 revolutions. Further, after every five revolutions of the turntable, the load cell jumper was removed and reinstalled. The system performed as designed throughout the test. Accuracy of the weighing system was $\pm 3 \%$. There was no apparent damage to the load cell 
or modified Hanford connector from the repeated removal and installation of the jumper. (The instrument connector is described in Section 5.0.).

\subsubsection{Turntable/Melter Bellows Seal}

The bellows seal was tested for inleakage at inflation pressures between 40 psig and 90 psig. The inflation pressure was increased in 10 psig increments. Each inflation pressure was tested three times to establish accuracy of air inleakage data. The tests showed that the assembly will make a satisfactory seal over the entire range of pressures tested. All tests were run with $10-i n . H_{2} \mathrm{O}$ vacuum applied to the inside of the bellows assembly. At 40-psig inflation pressure, the air inleakage was $9-1 / 2 \mathrm{scfh}$. When the inflation pressure was increased to 9-psig, the air inleakage was $4 \mathrm{scfh}$. Tests were also ran at an inflation pressure of $35 \mathrm{psig.} \mathrm{At} \mathrm{this} \mathrm{pressure,}$ sealing was not accomplished. When the inflation pressure was increased to $37 \mathrm{psig}$, the air inleakage dropped to $11-3 / 4 \mathrm{scfh}$. Since design calculations had indicated that sealing would be achieved at -37 psig, the seal system worked as designed. Repeated inflation of the bellows during the tests did not cause any elongation of the bellows. Remote installation and removal of the bellows seal were successfully accomplished.

\subsubsection{Turntable Positioning Device}

The scissors mechanism used for positioning the turntable was tested in conjunction with the melter-to-turntable bellows seal test. In between inflation cycles of the bellows, the turntable was moved from under the melter shel1, then returned to its operating position using the scissors mechanism. It was found that the scissors operated smoothly, although an antirotational device needs to be installed for the impact wrench.

\subsection{CONCLUSIONS}

- The scissors mechanism for remotely positioning the turntable works well.

- The canister access port sealing system functions well.

- Remote handling of canisters with the design grapples, is acceptable. 
- The drive system functioned as designed.

- Function of the canister weighing system and remote handling aspects of the load cell jumper are acceptable.

- The turntable/melter bellows seal system perform as designed.

- A potentiometer is not satisfactory for determining canister location with respect to the melter discharge port.

\subsection{RECOMMENDATIONS}

1. An LVDT system should be used for indicating canister position in the turntable.

2. The canister grapple should be redesigned to give more clearance at the grapple/canister interface.

3. A different inner seal should be used on the turntable canister access port as "E" seals of low loading rates, 4 lb/circumferential inch, are not obtainable.

4. A method for protecting the inner seal of the turntable access port during remote installation should be investigated.

5. The turntable/melter bellows seal mounting bolts and alignment dowels should be outside the bellows to provide better visibility during installation and removal. 


\subsection{MELTER DISCHARGE SECTION}

The discharge section provides a heated path for molten glass to flow from the melting cavity to the product canister, located in the turntable below the melter. Figure $3-1$ is a schematic of the melter discharge section. The discharge section heat source consists of ceramic heating elements mounted in a remotely removable lid. The lid is designed to be removable since the lid elements are expected to have a shorter service life than the melter and may require replacement.

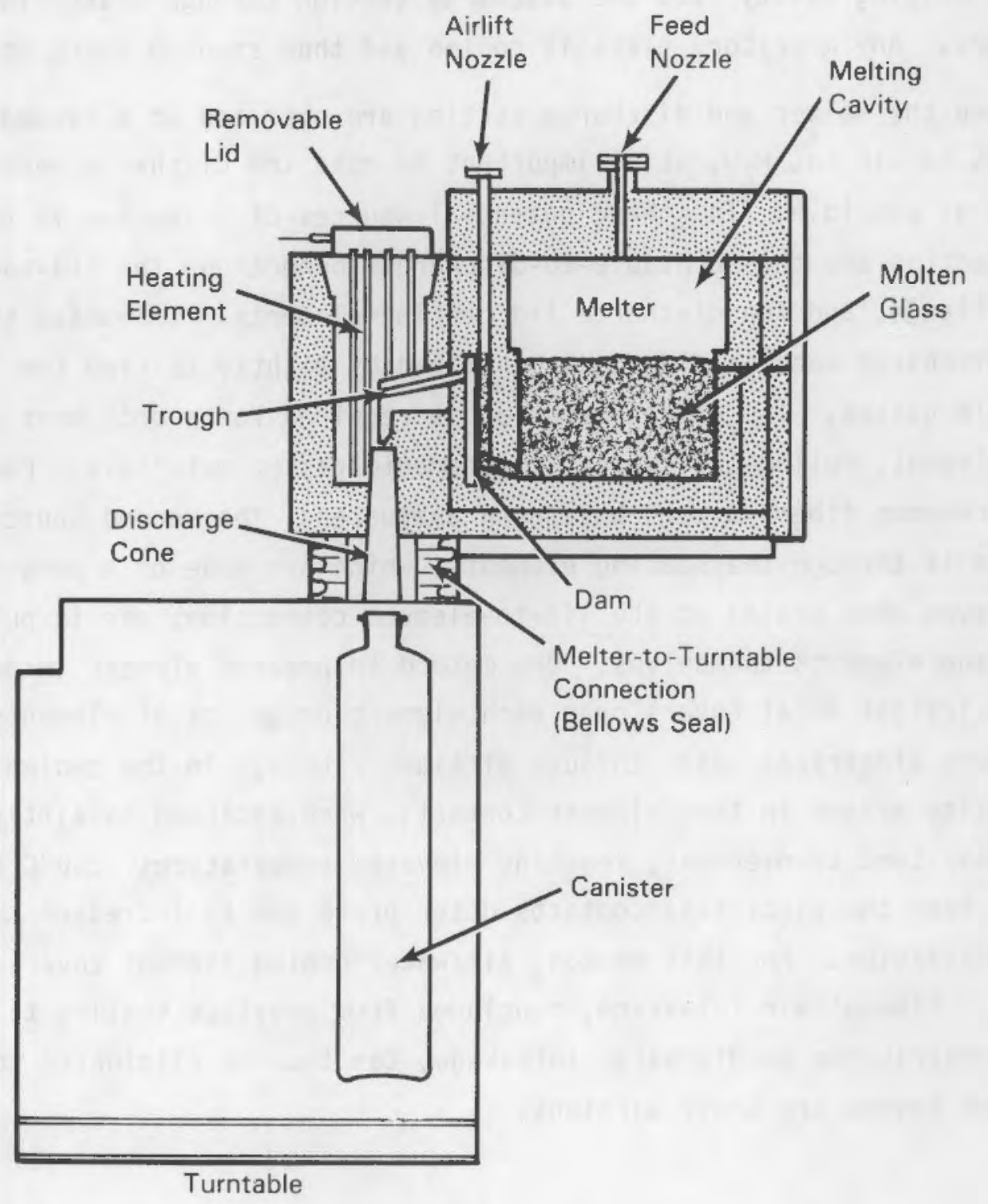

FIGURE 3-1. Discharge Section of Melter Planned for HWVP 
Molten glass flows from the melting cavity, up a refractory riser block, past an air-cooled metal dam, and into a horizontal metal trough, which is heated through radiant heat transfer from the lid heating elements to a temperature of $-1000^{\circ} \mathrm{C}$ or more. Glass flows through the trough, over a pour spout at the end of the trough, and falls through a discharge cone in a thin stream into an open canister. The discharge cone is a hollow liner, through which the glass falls, that extends from the pour spout to the canister. The discharge cone is described in detail in Section 4.0. An air-cooled metal wall positioned at the trough entrance prevents the migration of molten glass from the melting cavity into the discharge section through cracks in the refractory. Any migratory glass is cooled and thus stopped short at the dam.

Since the melter and discharge section are operated at a vacuum, usually around -5 to $-10 \mathrm{in} . \mathrm{H}_{2} \mathrm{O}$, it is important to make the discharge section as airtight as possible. The three potential sources of inleakage in the discharge section are the turntable-to-discharge connection, the 1id-to-discharge section flange, and the discharge lid heating elements. Inleakage through the lid-to-discharge section flange is minimized by tightly bolting the lid onto a deformable gasket. The gasket material is required to be both heat and radiation resistant, ruling out typical elastomeric gasket materials. For this reason, ceramic fiber gaskets have been evaluated. The second source of inleakage is through the heating elements, which are made of a porous material so that even when sealed at the lid-to-element connection, air is pulled through the elements themselves. One method to prevent element inleakage is to weld airtight metal covers over each element or groups of elements and pass the element electrical leads through airtight fittings in the cooled covers. A complexity arises in that element contacts, when enclosed in airtight covers, may tend to overheat, reaching elevated temperatures $\left(250^{\circ} \mathrm{C}\right.$ and higher) where the electrical contacts deteriorate due to increased contact surface oxidation. For this reason, air/water-cooled element covers have been designed. Element air inleakage, concluded from previous testing to be the largest contributor to discharge inleakage, can thus be eliminated to the extent the covers are truly airtight. 
Testing involving the remote handling characteristics of the discharge lid, air inleakage characteristics, and the thermal and operating characteristics of the discharge section, including the refractory, heating elements, cooled dam and trough components, is described below. Testing involving the remotely removable discharge cone is described in Section 4.0 .

\subsection{TEST EQUIPMENT}

A full-scale, thermally similar mockup of the discharge section was built and tested along with a prototypical discharge lid. The discharge mockup, shown in Figure 3-2, is a simplified version of the discharge section as planned for a melter. Where possible, castable refractory was used in the mockup rather than cut refractory brick, with thermal similarity achieved by adjusting the thicknesses of the cast and board refractory materials. Only the cut K-3 Monofrax refractory brick, located behind the trough, had to be duplicated in the discharge mockup. The interior dimensions and surface refractory materials within the mockup are identical to those originally planned for the discharge of a melter. The metal trough component in the thermal mockup is of the same general shape as that in an actual discharge section, but is made of SS rather than Inconel. The cooled dam is of the correct shape, but is also made of SS rather than Inconel. Stainless steel was chosen for the thermal mockup due to its lower material and fabrication costs, and for its heat transfer and thermal expansion similarity with Inconel.

In addition to the lid heating elements, the molten glass within the melting cavity constitutes a discharge section heat source, with heat conducted from the molten glass, through refractory brick to the rear of the trough and air-cooled dam. The thermal presence of the molten glass was simulated using two plate heaters placed on the diagonal surface of the $\mathrm{K}-3$ Monofrax bricks and operated at refractory midline temperature of $950^{\circ} \mathrm{C}$.

Heat losses from the discharge section are due to cold air inleakage, radiant heat transfer to the relatively cool canister below the discharge section, and natural convection from the exterior surface of the discharge section to the ambient cell environment. Air inleakage through the discharge 


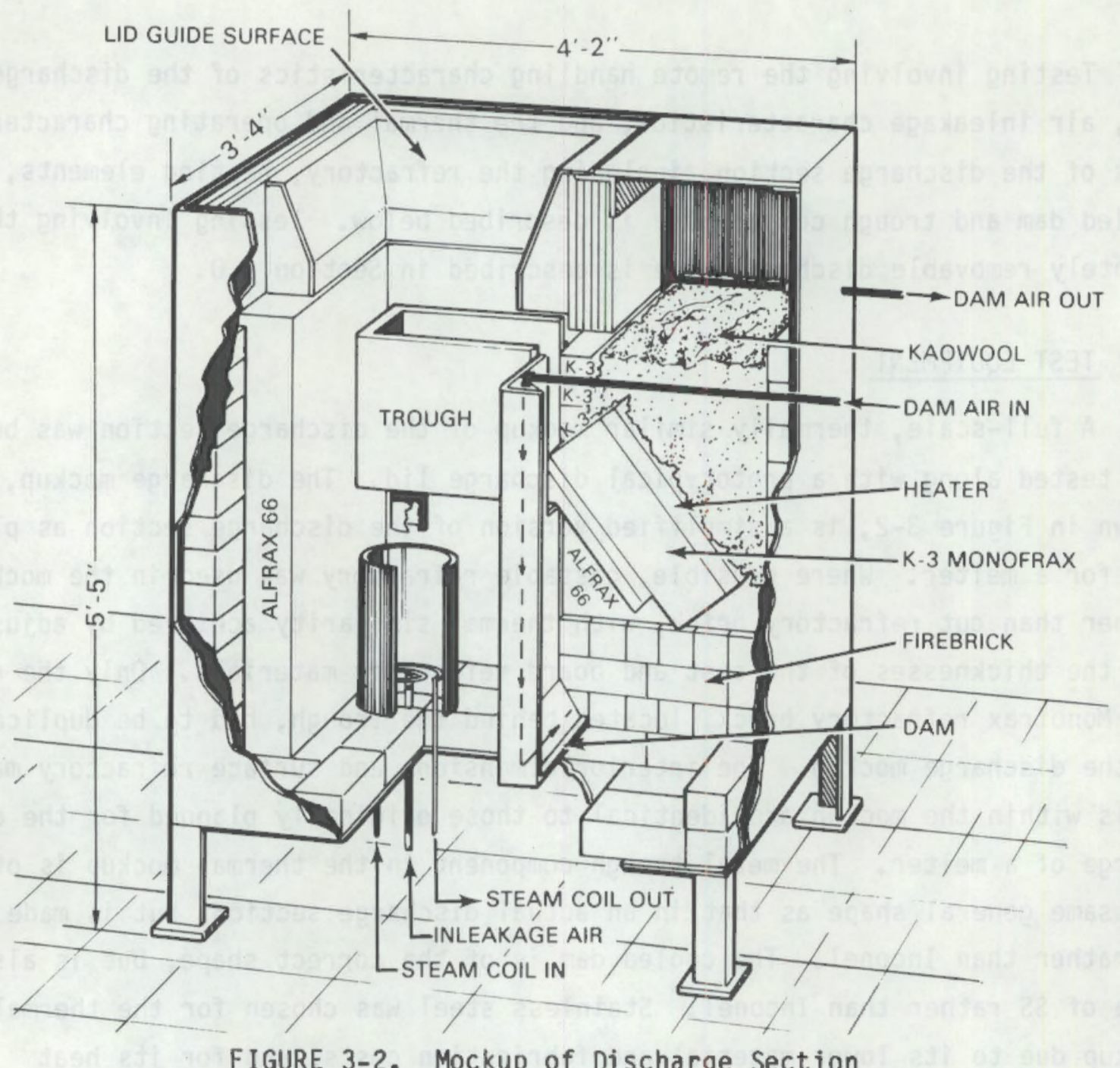

FIGURE 3-2. Mockup of Discharge Section

lid was simulated by operating the mockup at a vacuum and allowing the air to leak in through a ceramic rope lid gasket. Possible air inleakage through the turntable-to-discharge connection was simulated using an adjustable flow rate air line in the floor of the mockup. The presence of a cold canister was simulated with a dish-shaped steam coil located in the mock discharge cone at the floor of the discharge mockup. Finally, heat loss through the discharge walls was simulated by achieving a thermally similar refractory wall in the discharge mockup. Since the ambient temperature in the test environment is $25^{\circ} \mathrm{C}$, while that in-cell is expected to be $50^{\circ} \mathrm{C}$, wall losses per unit area will be slightly higher in the mockup, and exterior wall temperatures are anticipated to be lower in the mockup. 


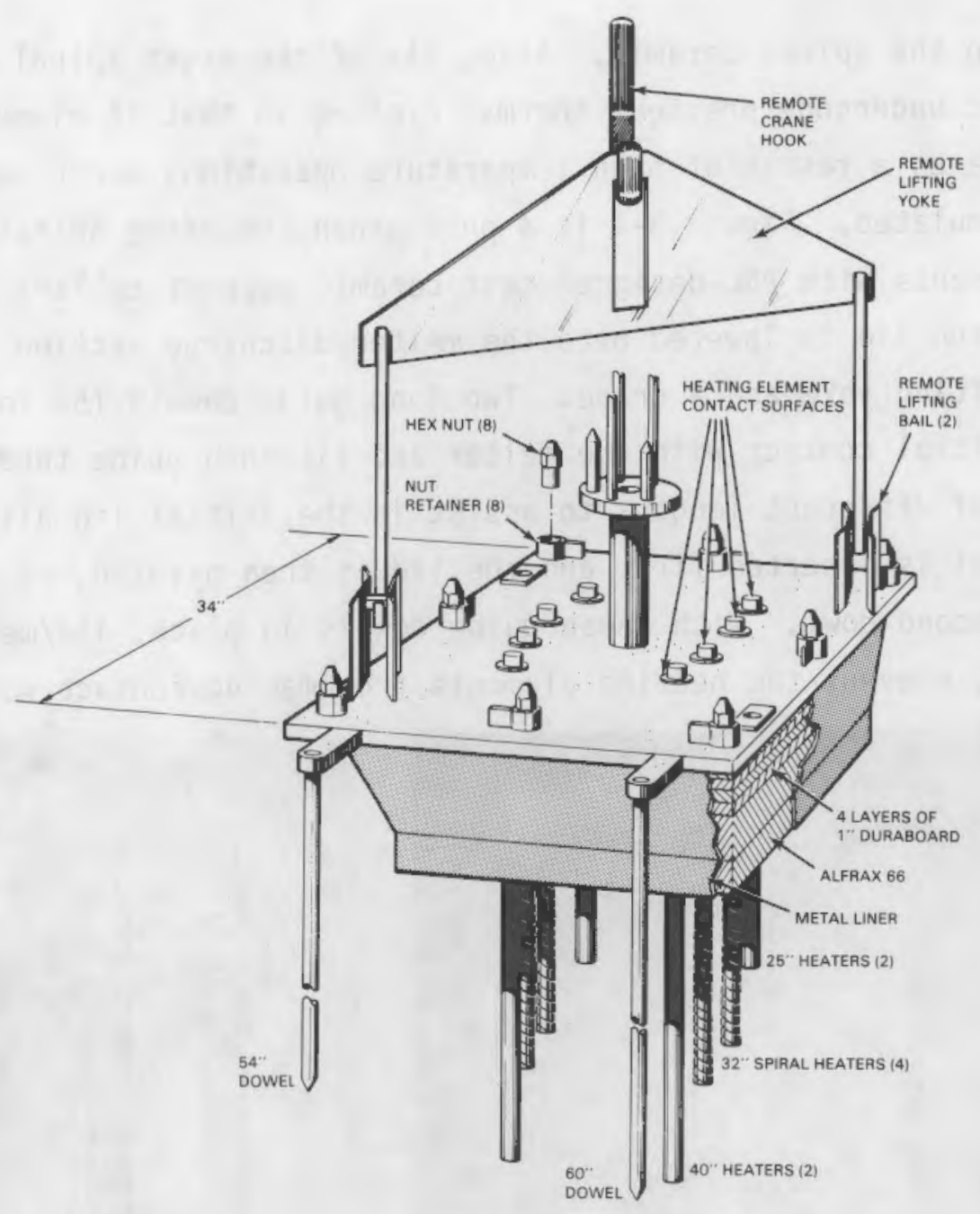

FIGURE 3-3. Melter Discharge Lid Prototype

The prototype discharge $1 \mathrm{id}$, as constructed for testing, is shown in Figure 3-3. The lid was fabricated in accordance with the dimensions and materials as planned for the HWVP melter. Only the heating elements used on the prototype lid are of a different type than planned. The intent was to set up a "worst case" scenario for remote testing by using the more brittle spiraltype heating elements in four of the eight lid element locations, rather than using only coaxial elements. Both types of element are made of a brittle silicon carbide (SiC) ceramic which must be protected during remote installation of the discharge lid. The use of the fragile spiral-type elements in remote lid testing allows a more sensitive evaluation of heating element survivability. A coaxial element is a rod within a cylinder, which is more 
durable than the spiral ceramic. Also, six of the eight spiral and coaxial elements had undergone previous thermal cycling so that if elements become more brittle as a result of high temperature operation, worst case embrittlement was simulated. Figure $3-4$ is a photograph comparing spiral and coaxial heating elements with PNL-designed cast ceramic support collars. The discharge section lid is lowered onto the melter discharge section using lid bails, a lifting yoke and a crane. Two long guide dowels (54 in. and 60 in.) make the initial contact with the melter and fit into guide tubes. The long dowels are of different lengths to assist in the initial lid alignment. The longest dowel is inserted first and the lid is then pivoted, as required, to align the second dowl. With these guide dowels in place, lid/melter alignment is achieved, prevent the heating elements from making contact with the melter
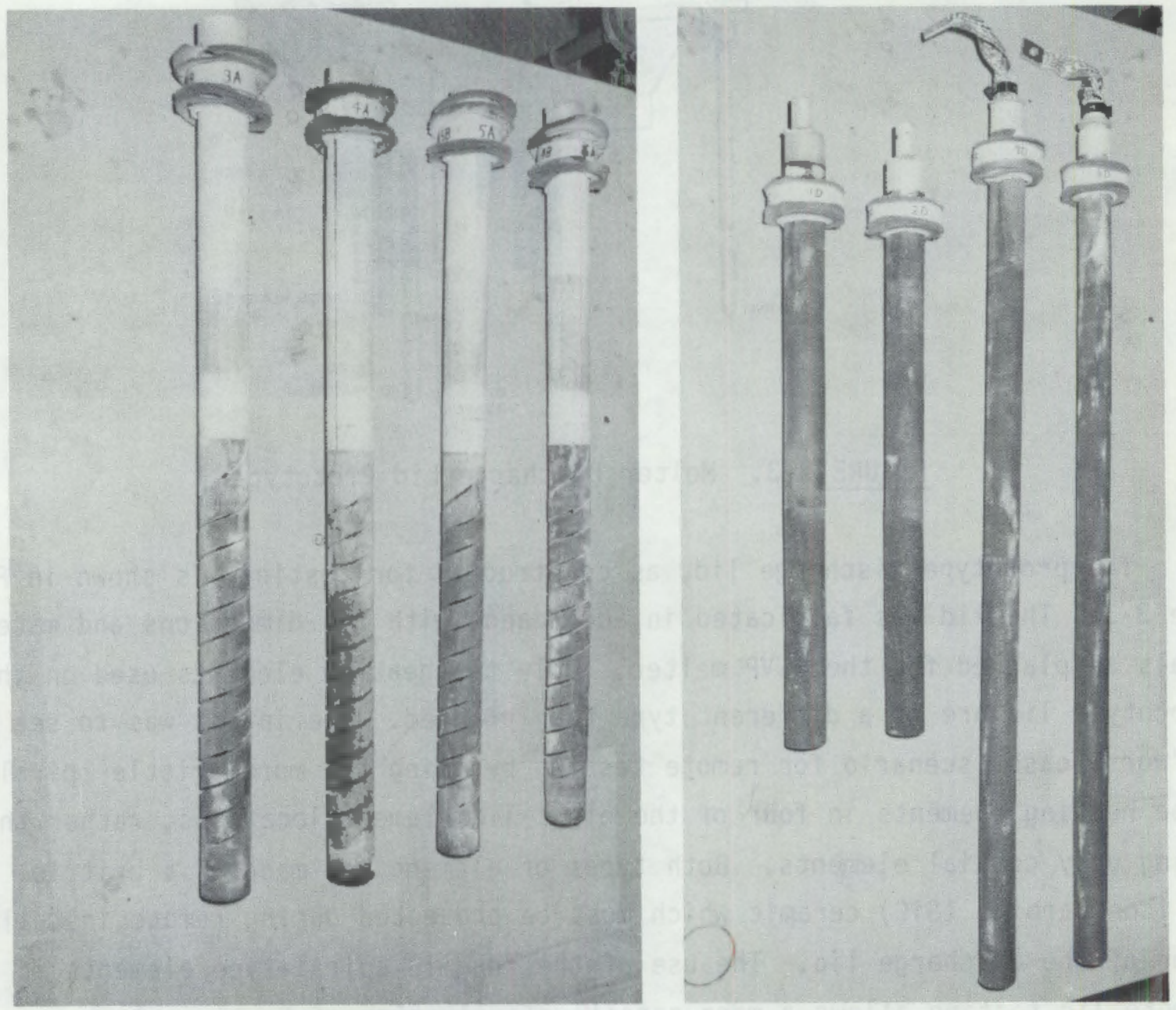

FIGURE 3-4. Heating Elements Tested in the Prototype Discharge Lid 
during further lowering. As the lid is lowered, two short guide dowels on the melter provide final alignment. This final alignment ensures that the threaded remote studs on the melter fit through holes in the lid without damaging the stud threads. Nuts held within nut retainers on the lid fit loosely over the studs once the lid is lowered into place. The lid-lifting yoke is removed from the crane and a crane-held impact wrench tightens the lid nuts, securing the discharge lid to the melter. To remotely remove the discharge lid from the melter, the same steps are followed in reverse order.

In industrial practice, element electrical connections are made using aluminum wire braid clamped around the electrical contact surfaces of the element, which are sprayed with aluminum paint for low contact resistance. Electrical power wires are connected directly to the wire braid. This type of element connection is usually left unenclosed since its maximum operating temperature is considered to be only $250^{\circ} \mathrm{C}$. As mentioned earlier, the melter is operated at a vacuum, and air inleakage through the porous elements can be minimized by enclosing the elements in airtight metal covers. Even if the walls of the covers are cooled, contact temperatures above $250^{\circ} \mathrm{C}$ must be anticipated. For this reason, a new type of high-temperature $\left(400^{\circ} \mathrm{C}\right.$ to $\left.550^{\circ} \mathrm{C}\right)$ contact hardware configuration has been developed based on proprietary contact interface bands. In this configuration, electrical power wire is connected to element leads that are integrated into a clamping device that holds the contact interface band securely in contact with the heating element surface. The interface band is made of a springy nickel/cobalt/chromium alloy; the clamp is made of phosphorus bronze; and both are gold plated. Figure 3-5 is a photograph of element electrical connection hardware.

In addition to testing the new electrical contact hardware, the sprayedon aluminum element coating was modified since its resistivity increases at high temperatures due to increased surface oxidation. One coaxial element was stripped of its aluminum coating and left bare, one was plated with -50 microns of copper over a bare surface, one with - 50 microns of nickel over a bare surface, and one was plated with -50 microns of copper over the manufacturer-applied, aluminum-sprayed contact surface. The contact surfaces of the four spiral-type elements were left unmodified. 

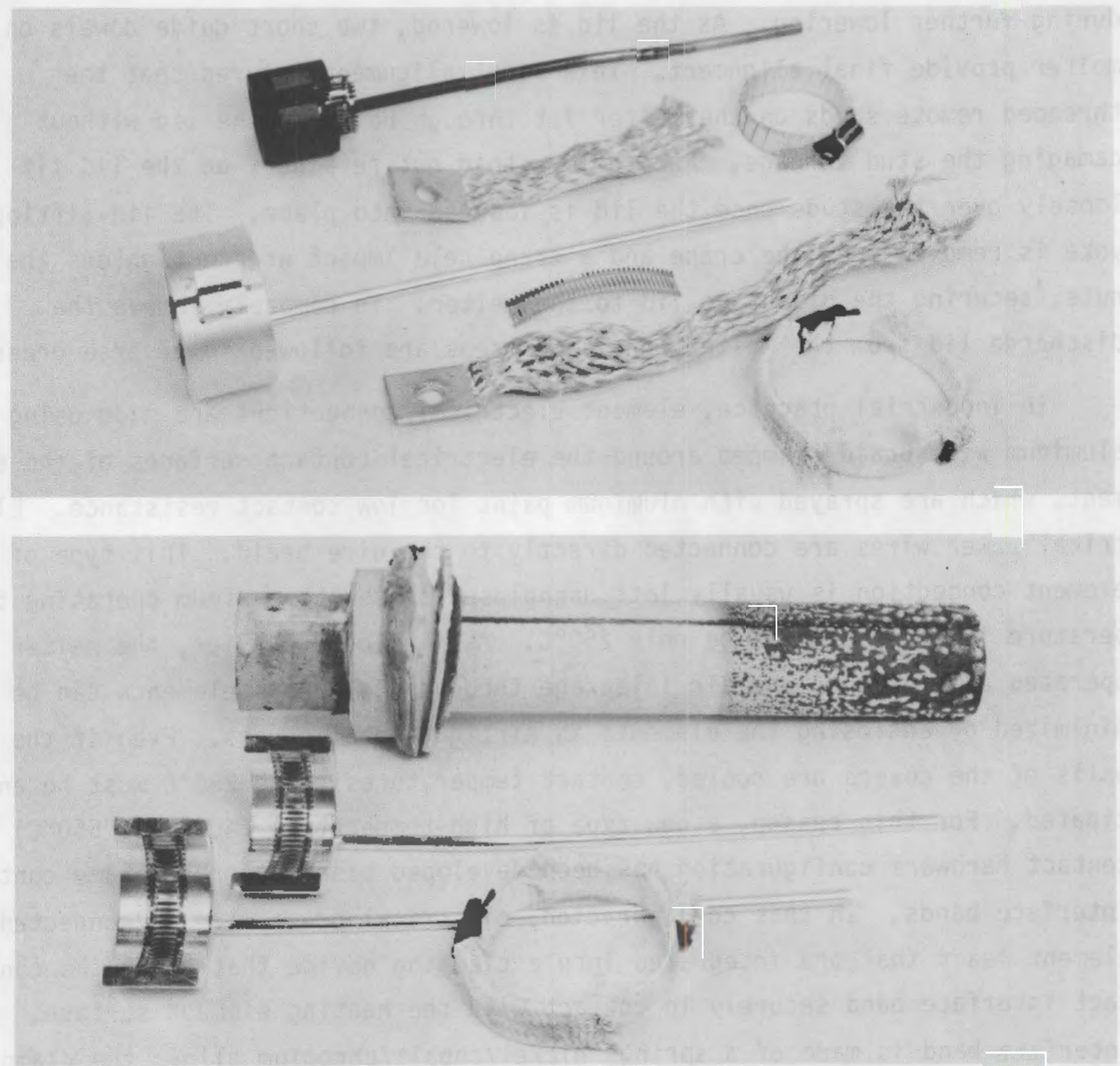

FIGURE 3-5. Hardware for Lid Element Electrical Connections

\subsection{TEST APPROACH}

Two important purposes of the discharge section testing are to determine whether the discharge trough remains hot enough to maintain flowability of the molten glass, and whether dam temperatures can be maintained low enough to prevent the seepage of molten glass from the melting cavity into the discharge section.

Testing involved continuously measuring trough, dam, and other internal discharge temperatures, while varying discharge heat source and heat sink 
parameters. The internal plenum temperatures were held constant at $1050^{\circ} \mathrm{C}$ $\pm 50^{\circ} \mathrm{C}$, while the plate heaters, simulating the thermal presence of the melting cavity, were maintained at $950^{\circ} \mathrm{C} \pm 25^{\circ} \mathrm{C}$ throughout the test. The heat source and heat sink parameters, investigated for their effect on trough temperatures, were: a) the presence of a cold canister; b) the failure of heating elements; c) the rate of melter-to-turntable connection air inleakage; and d) the rate of dam air flow. These parameters are discussed below in more detail. The discharge mockup was held at a vacuum of $-8 \mathrm{in} . \mathrm{H}_{2} \mathrm{O} \pm 2 \mathrm{in}$. to duplicate the inleakage of air through the discharge lid during melter operation.

The effect of the presence of a cold canister on trough temperatures was evaluated by running steam at $-250^{\circ} \mathrm{C}$ through a copper coil within the mock discharge cone directly below the trough pour spout. The steam coil was allowed to run for several hours and then turned off so that any effect on trough temperatures could be measured. Other test parameters were maintained constant.

The effect of a "loss" of a heating element and groups of elements on trough temperatures was characterized by abruptly disconnecting heating elements and noting trough temperature changes. Unplanned element failure was also experienced, adding to the element loss test data.

The effect of air inleakage through the melter-to-turntable connection was characterized by running cold air up through the base of the mock discharge cone at the floor of the discharge mockup. The rate of air flow in this simulated air inleakage line was varied from $0 \mathrm{scfm}$ to $8.5 \mathrm{scfm}$, so that the subsequent changes in trough temperatures could be observed.

The performance of the metal dam in preventing molten glass migration was characterized by measuring dam surface temperatures as a function of dam cooling air flow rate. The effect of the cooled dam on trough temperatures was also evaluated.

A third important goal of discharge testing was to characterize the rate of air inleakage through the discharge lid's gasketed flange. This was done by bolting the discharge lid onto the melter shell, located in the remote 
operations test facility, varying the magnitude of the vacuum in the melter from -20 in. $\mathrm{H}_{2} \mathrm{O}$ to +5 in. $\mathrm{H}_{2} \mathrm{O}$, and measuring the rate of air inleakage into the melter shell. After characterizing the base rate of melter shell inleakage, a flat ceramic fiber gasket and a ceramic fiber rope were each evaluated for their air inleakage resistance when serving as a discharge lid gasket. Inleakage associated with the two cooled covers on the lid was also measured.

A fourth area of discharge testing was involved in characterizing the performance of the discharge lid heating elements. As mentioned in Section 3.1, heating element performance depends on: a) the method of electrical contact, b) the type of hardware at the top of the element, c) the type of metal coating or lack thereof on the contact surface, and d) the temperature of the contact environment, which depends on whether the contacts are left open to the cell environment or enclosed. Two types of element contact hardware were field tested and evaluated by monitoring the contact temperature (using a thermocouple mounted on the hardware), and by noting the visible condition of the hardware before and after testing. A method for removing manufacturer-applied aluminum coating using $1 \mathrm{M} \mathrm{NaOH}$ was evaluated along with a method for plating metals onto the surface of the SiC elements. The effect of the type of contact surface on element performance was evaluated by measuring the contact clamp temperatures where the same type of clamp is used on the four different element surfaces. The lower the contact temperature, the less likely the contact clamp will burn out and the greater the longevity of both the contact $c l a m p$ and the heating element. Unfortunately, two of the elements containing PNL-electroplated test surfaces were damaged during installation, so could not be tested. The overall resistance of the element and contact hardware was calculated based on element amperage and voltage data to allow a second method of characterizing element performance. The temperatures of both enclosed and unenclosed element contacts were measured to determine the effect of the enclosures on element performance.

The jacketed element enclosures were cooled with air at various flow rates, water at one flow rate, and left uncooled. The temperatures of the enclosure environment were measured, as well as the contact clamp temperatures 
within the enclosures. The heat duty associated with the jacketed enclosures is estimated based on cooling air outlet temperature, flow rate, and enclosure surface temperature.

A fifth goal of the test was to determine whether the metal and refractory materials can survive the discharge operating temperatures and thermal cycling. Data for this test consisted mainly of: a) photographs of the materials before and after testing, b) mapping of refractory cracks, c) measurement of metal component warping, and d) compositional analysis of dust and other fine debris in the off-gas line, and on the surfaces of the refractory, and of the heating elements.

A sixth goal was to determine the effectiveness of the refractory design in maintaining discharge wall heat losses. The wall losses were characterized by performing an energy balance on the discharge mockup and measuring exterior surface temperatures.

Finally, the seventh major goal of the discharge testing was to determine the feasibility of remotely installing the discharge section lid. In general, the feasibility of a remote operation is established by repetition of the operation, first with direct viewing and then with remote viewing. This standard approach was followed in evaluating the remotability of the discharge 1id. In addition to ensuring that the dowel and bolt holes in the lid flange are correctly aligned, an important purpose of the remote testing is to determine whether the elements would survive both the lid lowering and bolt tightening of remote installation. First, the elements could be damaged during the lid lowering if struck against part of the melter. Second, the elements could be damaged from vibrations transferred through the lid from the ratcheting action of the impact wrench which develops $\sim 450 \mathrm{ft}-1$ bs of torque during bolt tightening. The heating elements were examined for damage, both visually and by measuring heating element resistances using a multimeter after each remote operation. Element cracking would be detected by the measurement of an increase in resistance corresponding to a partially broken current path. No change in element resistance would indicate that no operational damage was sustained. 


\subsection{RESULTS}

The test results regarding melter discharge mockup and prototype lid testing are detailed in the appendix. Conclusions and Recommendations stemming from the results are presented next.

\subsection{CONCLUSIONS}

- The discharge section lid was demonstrated as being remotely installable and removable without damaging lid heating elements. Neither jarring the lid during installation nor bolt ratcheting caused element damage.

- The lid heating elements are capable of sustaining trough and pour spout temperatures at or above $1000^{\circ} \mathrm{C}$, and discharge cone temperature between $930^{\circ} \mathrm{C}$ and $1060^{\circ} \mathrm{C}$ at plenum temperatures of $\sim 1100^{\circ} \mathrm{C}$.

- Based on similarity calculations using the test data, it is estimated that the lid element power required will be $32 \mathrm{~kW}$ to maintain trough temperatures well above $1000^{\circ} \mathrm{C}$. The energy balance assumes a dam air flow of $8.0 \mathrm{scfm}$, a turntable inleakage of $3.0 \mathrm{scfm}$, and a lid inleakage of $3.0 \mathrm{scfm}$, contributing heat losses of $2.3 \mathrm{~kW}, 1.7 \mathrm{~kW}$, and $0.2 \mathrm{~kW}$, respectively.

- For the dam geometry tested, an air flow of $8 \mathrm{scfm}$ to $10 \mathrm{scfm}$ will be sufficient to stop the flow of glass migrating below the trough through refractory cracks.

- Turntable inleakage must be maintained at $<3.0 \mathrm{scfm}$ to avoid cooling pour spout temperatures below $1000^{\circ} \mathrm{C}$ at reference lid power levels. At a turntable inleakage rate of $8.5 \mathrm{scfm}$, at least $4 \mathrm{~kW}$ additional lid heating element power is required to maintain trough and pour spout temperatures. The more turntable inleakage, the more lid power is required.

- The loss of either of the four middle lid elements can cause a $50 \%$ reduction in trough and pour spout temperatures. Loss of two middle elements also caused a $50 \%$ trough/pour spout temperature reduction independent of which two of the four middle elements are lost. The 
loss of any one of the four corner elements has little effect on trough and pour spout temperatures.

- The thermal effect of the presence of a cold canister on pour spout temperatures is negligible based on radiant heat transfer similarity calculations using the test data.

- Heating element performance can be dramatically improved by removing the manufacturer-applied aluminum contact coating, and either leaving the element surface bare, or plating it with 50 microns of nickel. Copper plating was not as successful.

- Heating element contact temperatures can be sustained at $400^{\circ} \mathrm{C}$ when the PNL-designed contact hardware is used. The element manufacturerprovided hardware has a reported temperature limit of $250^{\circ} \mathrm{C}$.

- Element enclosures (cooled covers) were found to maintain the contact environment at $\sim 300^{\circ} \mathrm{C}$ with no cooling, $236^{\circ} \mathrm{C}$ with water cooling, and $246^{\circ} \mathrm{C}$ and $224^{\circ} \mathrm{C}$ with air cooling at $10.6 \mathrm{scfm}$ and $21.3 \mathrm{scfm}$, respectively. The air cooling heat duty at these two flow rates was found to be $1.75 \mathrm{~kW}$ and $2.80 \mathrm{~kW}$, respectively. Element contact temperatures varied from an average of $\sim 350^{\circ} \mathrm{C}$ during water cooling to $\sim 380^{\circ} \mathrm{C}$ with no cooling. The rate of air inleakage through the cooled covers, which incorporated gasketed lids, was found to be $\sim 1.0 \mathrm{scfm} /$ lid at a melter vacuum of -10 in. $\mathrm{H}_{2} \mathrm{O}$.

- The rate of inleakage through the main discharge lid gasket at a melter vacuum of $-10 \mathrm{in} . \mathrm{H}_{2} \mathrm{O}$ is $130 \mathrm{scfh}$ when an $1 / 8$-in. garlock flat gasket is used, and $150 \mathrm{scfh}$ when a 1-in. ceramic rope gasket is used. The inleakage data was found to be characterized by the following equations:

$$
F=\sqrt[17]{\frac{\Delta p}{\rho_{\mathrm{m}}}} \sqrt{g_{\mathrm{C}}} \text { and } F=19 \cdot \sqrt[4]{\frac{\Delta p}{\rho_{\mathrm{m}}}} \sqrt{{ }^{g_{C}}}
$$

for garlock and ceramic rope, respectively, where $F$ is air inleakage in scfm. 
- During thermal cycling, only minor refractory damage was noted except in the vicinity of the air-cooled dam, behind the trough. The damage was caused by slight warping of the dam. The dam itself was not damaged.

\subsection{RECOMMENDATIONS}

1. It is recommended that each of the four middle discharge lid heating elements be sized with respect to power output level for at least $200 \%$ of their anticipated normal power capacity to provide backup power in the event of failure of one or more elements.

2. It is recommended that longer lived elements than the coaxial type be employed in the discharge lid.

3. It is recommended that further long-term testing be done to assess the dependency of heating element performance on contact surface design.

4. It is recommended that the PNL-designed element contact clamps be modified to incorporate thinner, more deformable material that can be tightened on to the typically out-of-round heating elements.

5. It is recommended that small metal enclosures, cooled only by natural convection to the cell environment, be installed over heating elements to substantially minimize the overall rate of discharge inleakage.

6. It is recommended that the glass dam be provided with a gap of $\sim 1 / 4$ in. on the side facing the discharge trough to allow for warping of the dam, thus avoiding refractory damage. 


\subsection{DISCHARGE CONE}

The molten glass product stream flows through the discharge section along the metal trough, over the pour spout, and falls in a thin stream downward through a discharge cone assembly into a canister located below in the turntable. Although not normally requiring maintenance during the service life of the melter, the discharge cone may become plugged either as a result of canister overfilling or as a result of molten glass contacting the cone walls. In this event, the plugged discharge cone can be remotely removed and replaced through the canister access port on the turntable. This removable component is a safeguard against a melter failure that could be caused by plugging.

The discharge cone assembly consists of a hollow, remotely removable conical liner inserted within a permanent cone welded into the discharge port of the melter. The conical shape provides a good tapered guide surface for remote installation. Figure $4-1$ is a photograph of a prototype of the removable portion of the discharge cone assembly. The upper half of the removable cone is made of carbon steel and fits into the permanent cone in the melter discharge port, which is made of SS. When in place and operating at high temperature $\left(1050^{\circ} \mathrm{C}\right)$, the carbon steel inner cone tends to not stick to the SS permanent cone, allowing for easy removal of the inner cone.

The glass stream falling through the discharge cone is susceptible to cooling, which causes an increase in the viscosity and solidity of the molten stream. When excessive cooling occurs, the lower portion of the stream is colder and more solid than the very fluid stream leaving the melter pour spout. Such a gradient in stream temperature causes the upper, more fluid portion of the stream to flow faster than the cooler stream below, resulting in a bowing of the stream. If the stream bows out far enough to contact the walls of the discharge cone, the glass can stick and create an obstruction which can propagate across the cone resulting in a glass bird nest that may eventually plug the cone. Oxidation of the inner surface of the carbon steel prevents glass from sticking to the upper portion of the cone. To prevent excessive temperature change and bowing of the glass stream as it falls through the cone, the lower portion is fabricated of SS and is insulated with Kaowool. 

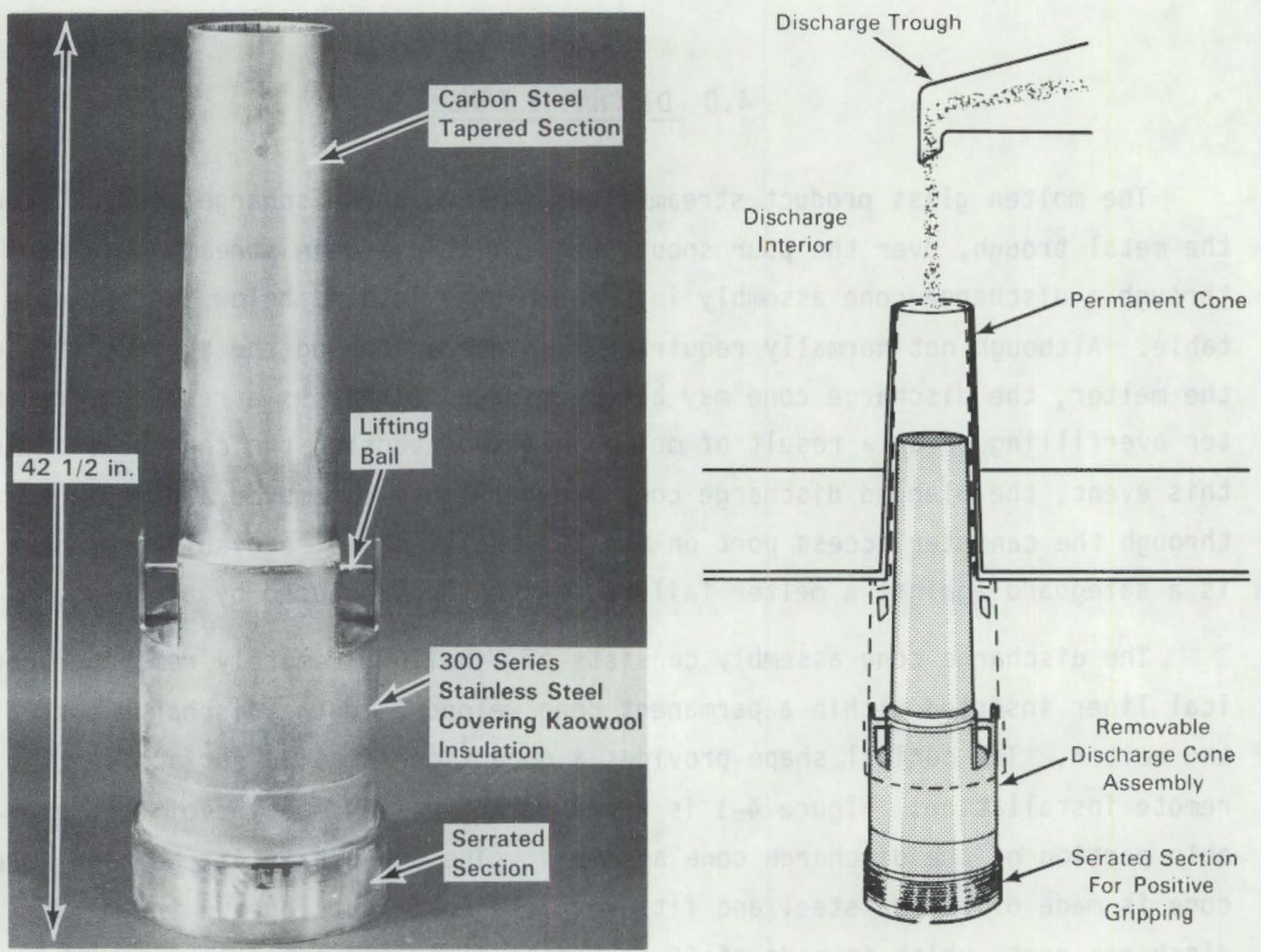

\section{FIGURE 4-1. The Discharge Cone Assembly}

As mentioned, in the event the discharge cone becomes plugged due to bird nesting or canister overfilling, the cone is designed to be removed along with the glass plug. Cone removal, as well as insertion, is accomplished using the discharge cone insertion tool shown alone in Figure 4-2A, and with the removal cone in place in Figure $4-2 B$.

To remove a plugged discharge cone, the insertion tool is fitted with an adapter ring, as shown in Figure 4-2C, and lowered through the canister access port of the turntable into an empty canister thimble. The turntable is then advanced $90^{\circ}$ placing the insertion tool with adapter ring under the plugged cone. Through a remote operation with specially adapted components, the tool removes the clogged cone and lowers it into the canister thimble. The turntable is then advanced back to the canister access port where the clogged 

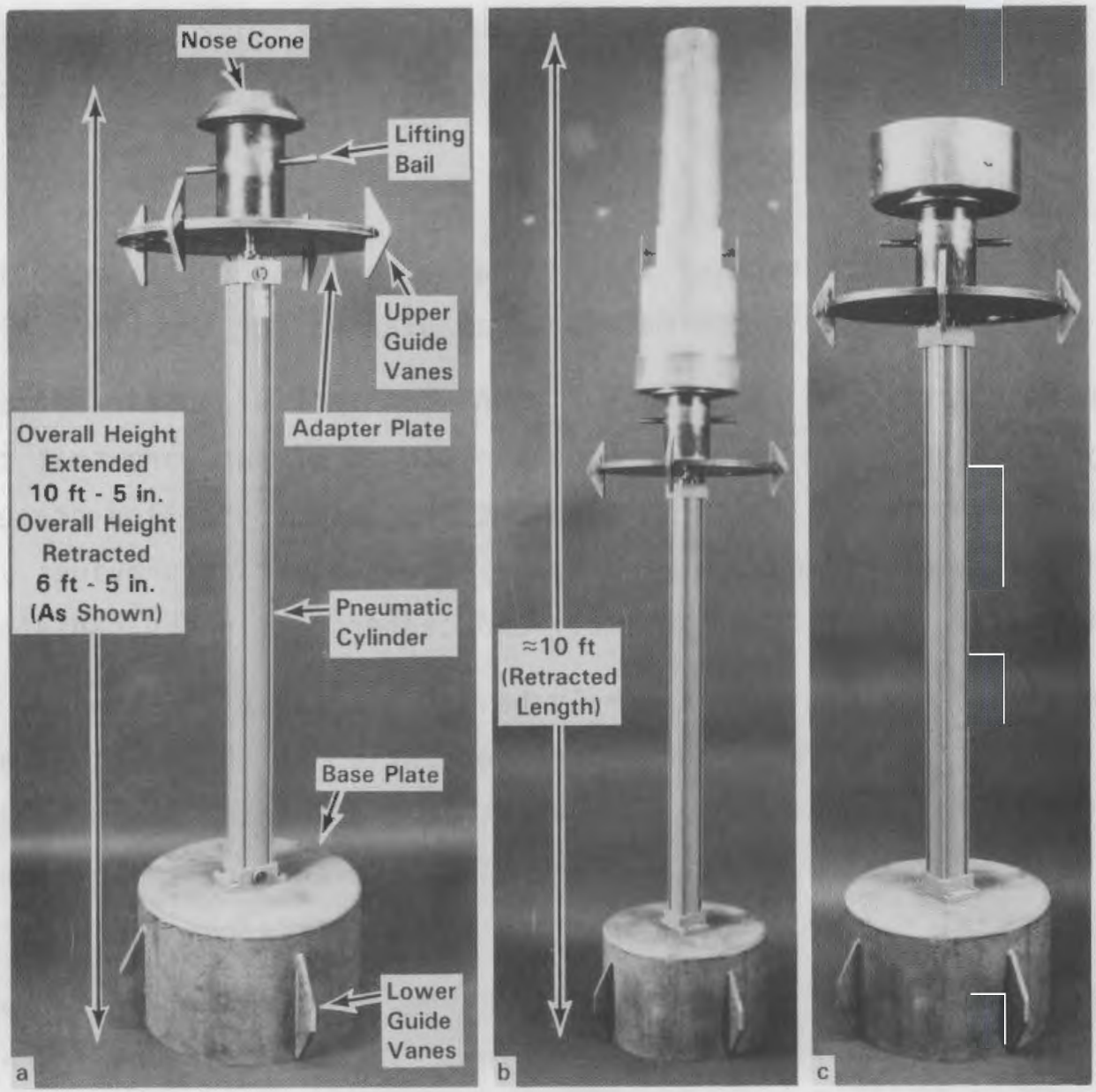

FIGURE 4-2. Discharge Cone Insertion Tool (A) with Cone (B) and with Removal Adapter Ring (C)

(C)

discharge cone and adapter ring are lifted off of the insertion tool using the cell crane. A new cone is placed on the insertion tool, and both are positioned under the discharge port. The new cone is installed using the insertion tool, which then is removed from the canister thimble.

In the event that a plug created by canister overfilling could be fused to the glass in the canister under the melter discharge port, the canister would then be frozen into place, preventing turntable rotation. If this happened during an otherwise normal canister filling operation, three glass filled canisters would be inaccessible from the discharge port. The turntable was designed to be pulled out from under the melter for superstructure removal and subsequent removal of filled canisters. The discharge cone would impede this removal. With foresight of this most extreme event, the discharge cone 
was designed for material failure at a shear plane 7-1/2 in. from the base, when subjected to the transverse force of the turntable removal mechanism.

\subsection{TEST EQUIPMENT}

A full-scale prototype of the discharge cone was constructed in accordance with the dimensions and materials as planned for the HWVP melter.

The discharge cone handling equipment consists of an air-operated pneumatic cylinder unit and several removable pieces of hardware that can be installed by a single lifting yoke on the remotely controlled crane. The pneumatic cylinder is mounted on a vaned base-plate that provides vertical orientation for the cylinder assembly and centers it in the canister liner.

The top of the cylinder assembly has an adapter plate mounted to the shaft with four guide vanes and a nose cone unit, which serves as a locating device for the discharge cone. The vanes on the adapter plate guide this unit in the liner when it moves up or down. The nose cone on the cylinder assembly has a horizontal rod protruding from the sides that serves as a lifting bail.

The insertion tool becomes the discharge cone removal tool when fitted with a discharge cone removal adapter ring. This ring serves to release the cone assembly from the cam grippers located on the base plate weldment. This removal adapter ring is designed to be moved upward to activate ejector cams if the cam grippers do not disengage from the cone upon contact. The ejector cams are designed to activate with an upward motion of the removal ring past the grippers, which causes a downward motion on the cam system that puts pressure on the stepped-section of the cone just above the serrated portion ejecting the discharge cone. Figure 4-3 shows cutaway details of the cam assembly.

To install a discharge cone, the pneumatic cylinder is lowered through the canister access port into the liner, which is inside the canister thimble, using the lifting yoke and the overhead crane. The guide vanes on the lower base plate center the pneumatic cylinder as it is lowered into the canister thimble. The unit is lowered until the base plate bottoms out in the canister 


\section{Outline of Inflatable}

\section{Metal Bellow Seal}

(Melter to Turntable Seal)

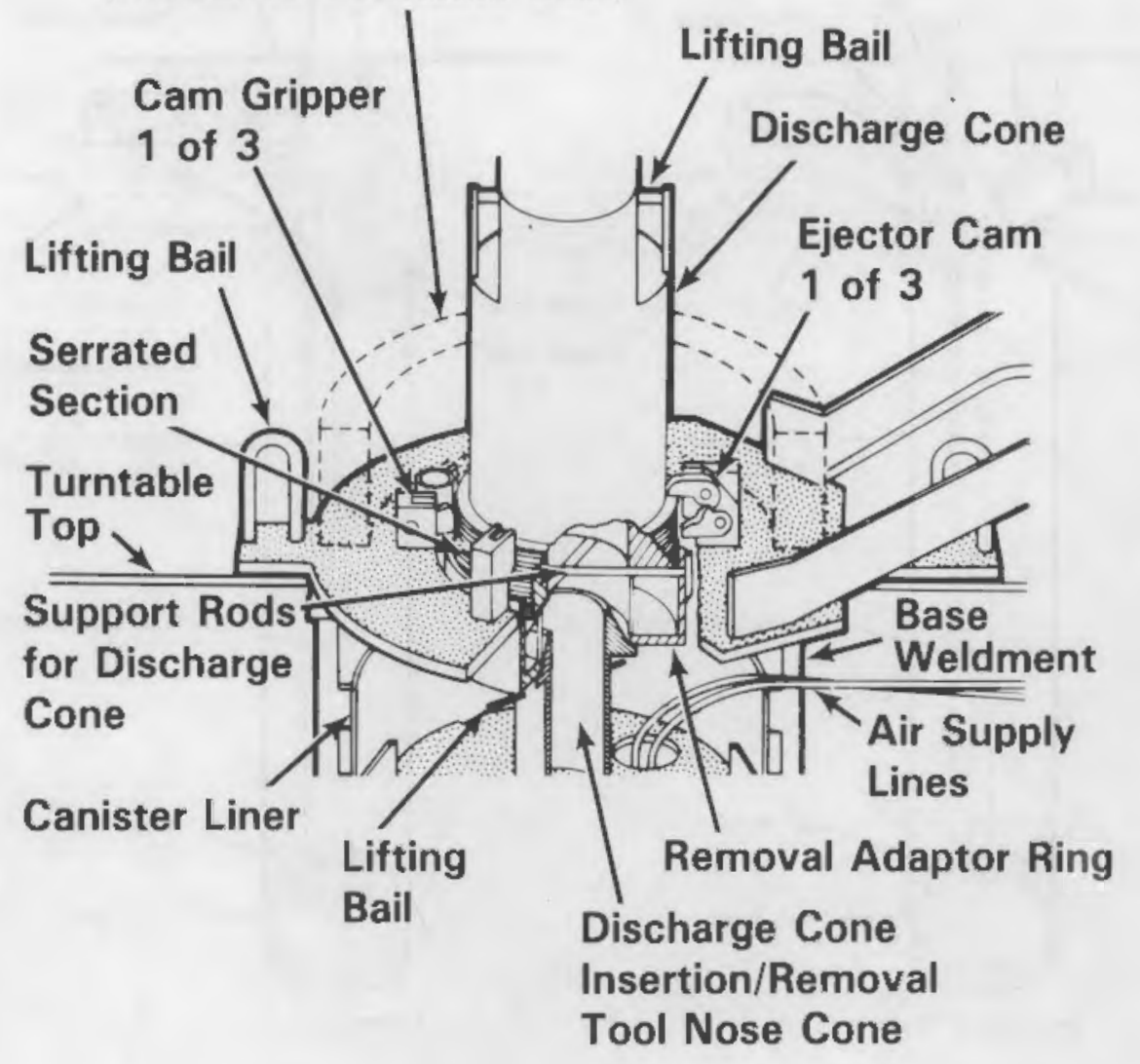

FIGURE 4-3. Base Plate Holding and Removal Mechanism

thimble and the cylinder shaft is in the fully extended position. The cylinder is pressurized for the upstroke position so that the lifting yoke may be disengaged.

Next, with the pneumatic cylinder pressurized for upstroke, the discharge cone is placed on the insertion tool nose cone using the lifting yoke. The pneumatic cylinder is next vented for upstroke and energized for downstroke to allow the discharge cone to be lowered into the thimble in the turntable. The turntable is then advanced $90^{\circ}$ to the melter discharge port where the discharge cone will be inserted. The next step is to raise the discharge cone through the turntable opening, up through the base weldment plate with the cam grippers, and into position (Figure 4-4). The cylinder is now pressurized for downstroke and the cone drops $\sim 1 / 16$ in. and is locked in place by the cam grippers. Removal of a clogged discharge cone is done in reverse order using the adapter ring shown in Figure 4-2C. 


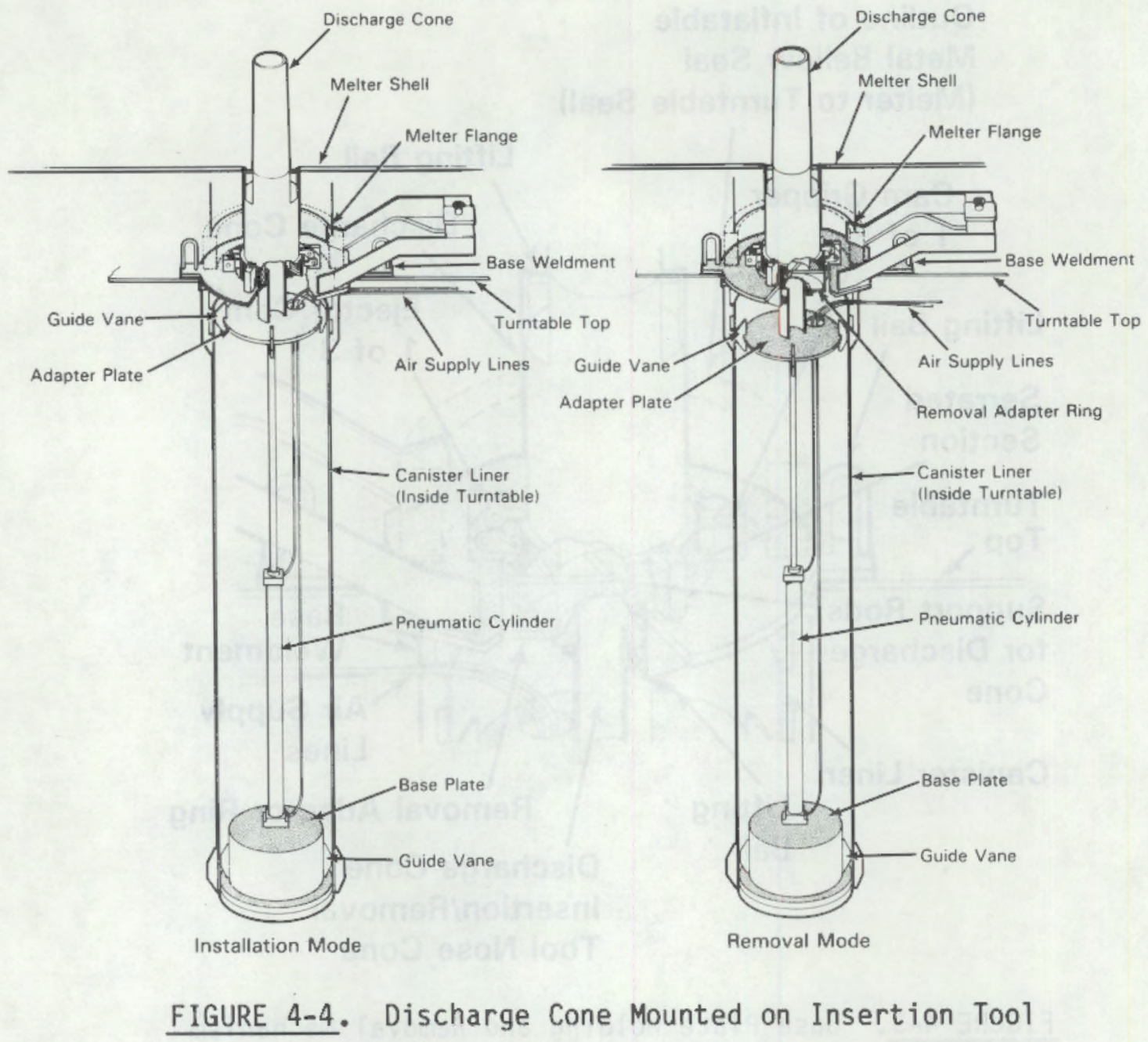

\subsection{TEST APPROACH}

The entire process of installing and removing the discharge cone from the base plate weldment located on top of the turntable at the canister fill port was performed several times with the turntable moved out from beneath the melter shell. The prototype discharge cone was then remotely installed in, and removed from, the mock melter shell twice with direct visual observation, and twice with closed-circuit cameras.

\subsection{RESULTS}

During the initial testing, only minor adaptations were required to allow adequate remote handling. A small amount of radial misalignment between the 
turntable access port to the melter mockup and the discharge cone atop the insertion tool caused the cone to catch on $i$ ts stepped insulated area by one of the ejector cams and not lock into place. The supply air pressure was increased from 20 psig to 45 psig to the pneumatic cylinder, which forced the stepped section of the discharge cone to bounce past the ejector cams and lock into place by the cam grippers. Adjustments were also required to the dimensions of the removal adaptor ring.

Subsequent testing with the turntable beneath the melter in normal operating configuration revealed that, during installation of the discharge cone, the top of the cone hit on the bottom of the melter shell adjacent to the inlet cone area leading into the overflow section of the melter mockup. This was caused by the slight radial misalignment between the melter, turntable port, and the discharge cone atop the insertion tool located in the canister thimble. Increasing the air pressure from 45 psig to 70 psig provided sufficient force to bounce the cone off the edge of the melter shell bottom and continue up into the proper position. This bouncing effect, demonstrated by the discharge cone at the higher air pressure to the pneumatic cylinder (70 psig versus $45 \mathrm{psig}$ ), does not result in dents or other distortions, and is, therefore, acceptable.

With the correct air pressures identified, the remote testing was completed with no difficulty.

\subsection{CONCLUSIONS}

- The discharge cone and holding mechanism (cam grippers) function correctly, as designed, based on visual observation.

- Should the discharge cone remain stuck after release of the cam grippers, the ejector cams will act on the cone to force release from the mel ter.

- The remote installation and removal equipment and discharge cone are remotely operable. 


\subsection{RECOMMENDATION}

1. It is recommended that all outside surfaces of the discharge cone, except the area acted upon by the ejector cams, be sloping to minimize areas of potential "hang-up" during installation. 


\subsection{ELECTRICAL AND INSTRUMENT CONNECTORS}

Most of the vitrification process instrumentation and equipment is located within remote cells that require electrical service lines and instrument leads to be passed through the cell wall to transformers, readouts, and recording devices in the operating gallery. Jumpers are used in-cell to connect process equipment with through-the-wall electrical and instrument lines. A multi-pin connector is used at each end of a jumper, allowing several instrument leads and/or electrical service lines to be connected in a single jumper, thus minimizing the number of process jumpers. Thermocouples, differential pressure cells, and other instruments generate small current (0-100 mA), or small voltage signals that require small, $-1 / 8 \mathrm{in}$. dia., pins for transmission. Up to 40 of these pins can be fitted in a signal connector. Electrical service lines require larger pins depending upon the amperage requirements of the equipment. Electrical connectors with 20 pins rated at $90 \mathrm{~A}$ each, 4 pins rated at $400 \mathrm{~A}$ each and a combination of 4 pins at $340 \mathrm{~A}$ each and 2 pins at $150 \mathrm{~A}$ each have been developed. A special closed circuit TV jumper, consisting of 20 instrument pins and one coaxial pin assembly, has also been developed. Design of the connectors was based on development activities conducted at SRL and incorporates proven Hanford remote connector technology. The combination pin electrical connector is based on the more modern PUREX connector technology, (the PUREX connector is more compact and easier to handle than the Hanford connector).

The sizes of connector pins are based on amperage requirements and are machined of brass and plated with rhodium-over-silver for low resistivity, high wear resistance, and good corrosion resistance. The pins are electrically isolated and arranged in radiation resistant fiberglass-reinforced plastic plates contained within the remote connector body. Figures 5-1 and 5-2 are photographs of the isolation plate/pin assemblies used in the remote 40-pin instrument connector and 20 pin, 90 A per pin electrical connector, respectively.

Initial results of SRL pin electrical resistance testing indicated the multi-pin electrical and instrument connectors to be feasible for use in a remote cell. Since actual performance testing was not included in the SRL report, performance testing of both a 40-pin instrument connector and a 


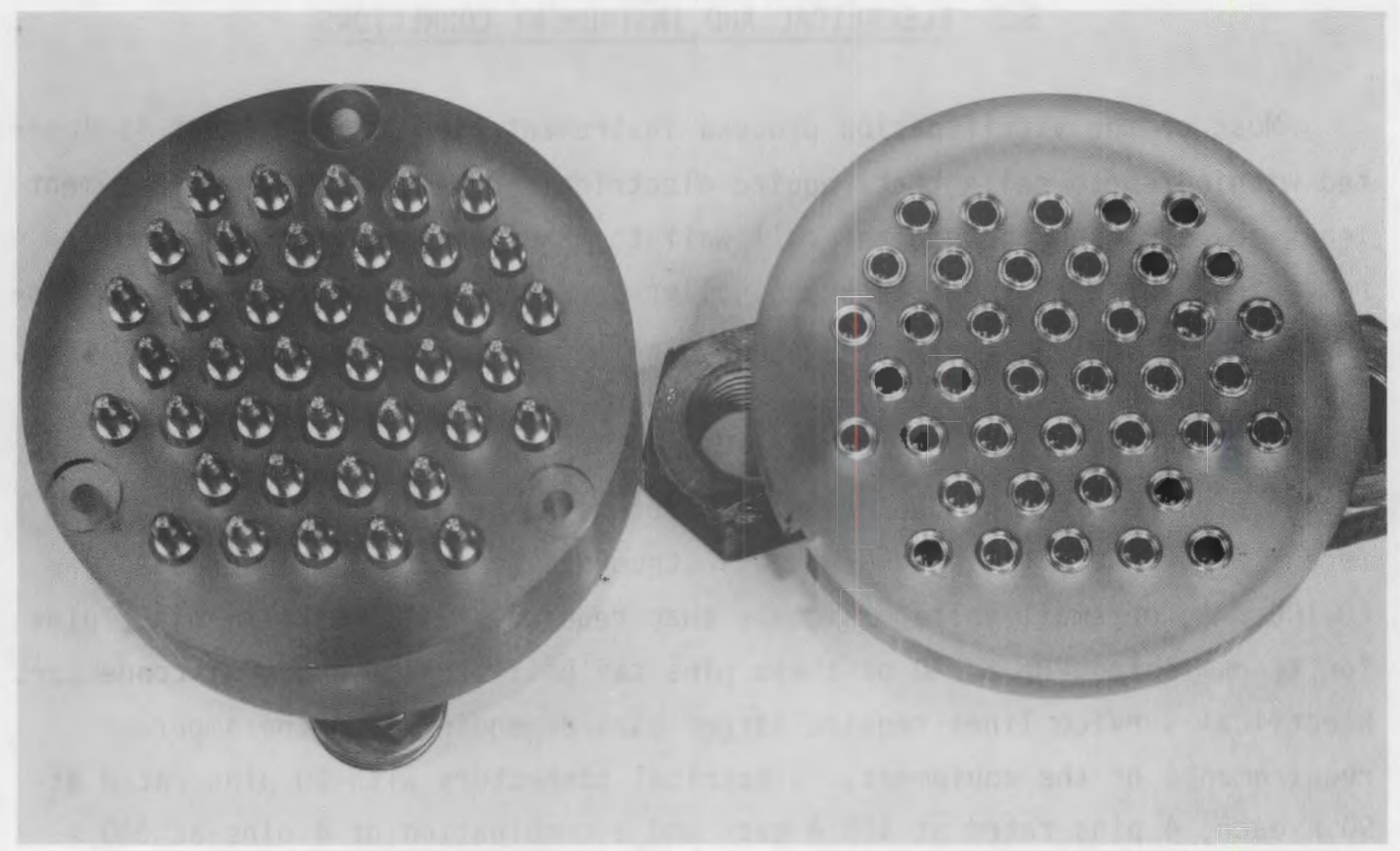

FIGURE 5-1. Remote Multi-pin Connector Internal Isolation Plates Shown With Pins and Sockets

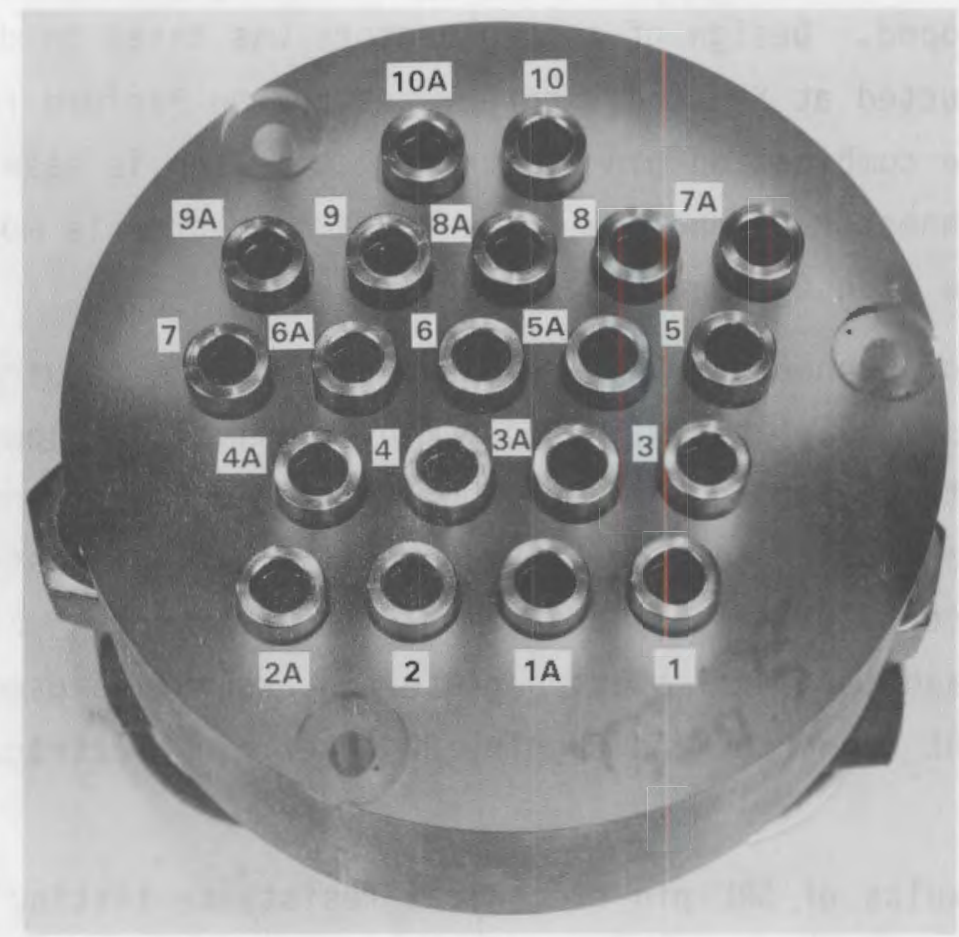

FIGURE 5-2. 20-Pin Test Connector and Locations on Plate Used in Test 
20 pin, 90 A per pin electrical connector were conducted as described in this report. Both remotability and electrical testing were performed.

\subsection{TEST EQUIPMENT}

Four connectors were built and tested to assess the remotability and signal transmittance current carrying capacity of the instrument, TV, and 20 pin, 90 A per pin electrical connectors.

A jumper containing a 40-pin instrument connector was built and tested to evaluate the remotability of the multi-pin connectors. The 40-pin connector was chosen for remote testing since it represents the most difficult remote installation because it contains the most pins. The test jumper (Figure 5-3) was connected to a strain gauge load cell for canister weighing, and was simultaneously tested for remote signal transmission.

Pin wear resistance and thermocouple signal transmittance were evaluated using a 10-pin version of the 40-pin instrument connector. The 10-pin connector consisted of a wall nozzle mounted in an instrument panel and a manually connected isolation plate, normally housed in a connector body on a jumper. The electrical sockets are contained in the wall nozzle, while the pins are contained within the jumper connector. Figure 5-4 shows the test version of the multi-pin connector.

A 20 pin, 90 A per pin connector with mock jumper (Figure 5-5) was built and tested to evaluate the current carrying capacity (ampacity) of an electrical connector.

A manually operated closed-circuit TV connector (Figure 5-6) was built and tested in conjunction with the in-melter viewing apparatus.

\subsection{TEST APPROACH}

Remotability testing using the 40-pin instrument connector mounted on a remote jumper was done in the remote operation test facility. The jumper was installed, bolted down using an impact wrench, removed, and reinstalled several times to assess the in-cell feasibility of the jumper. Installation/ removal was done with both direct viewing of the operation and indirect viewing 

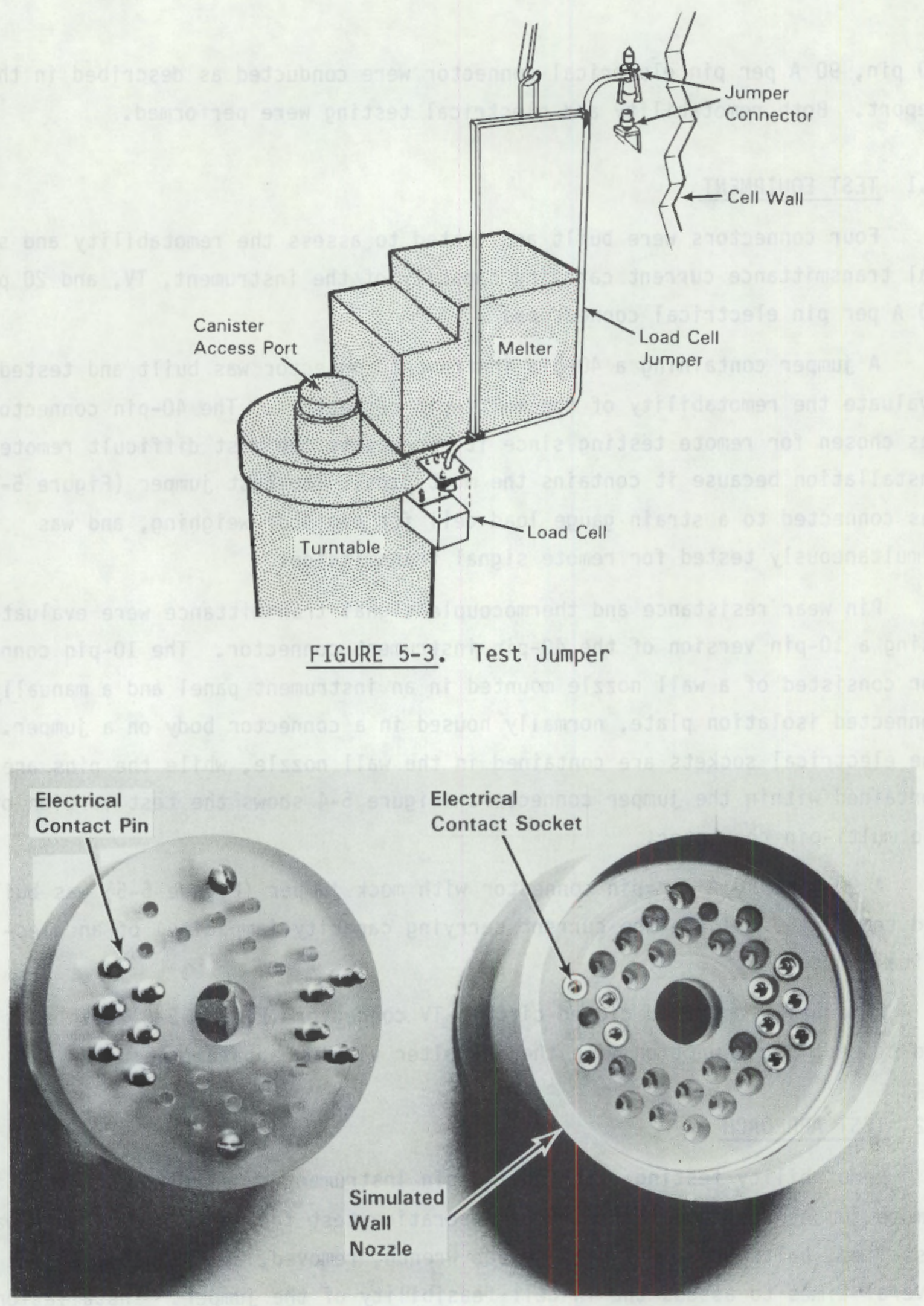

FIGURE 5-4. Test Version of the Multi-Pin Connector 


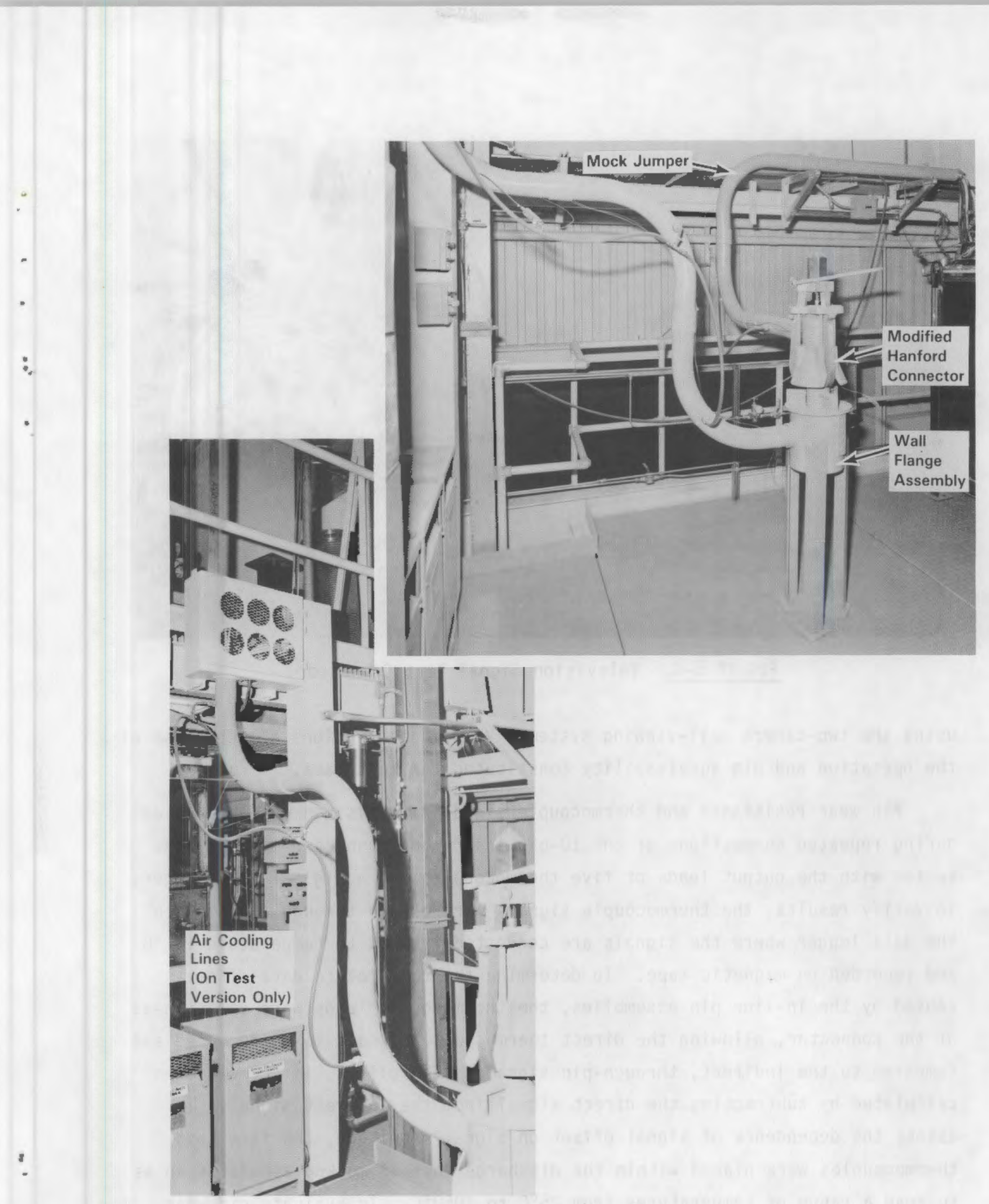

FIGURE 5-5. The 20 ea $\times 90$ Amp Connector Test Apparatus 


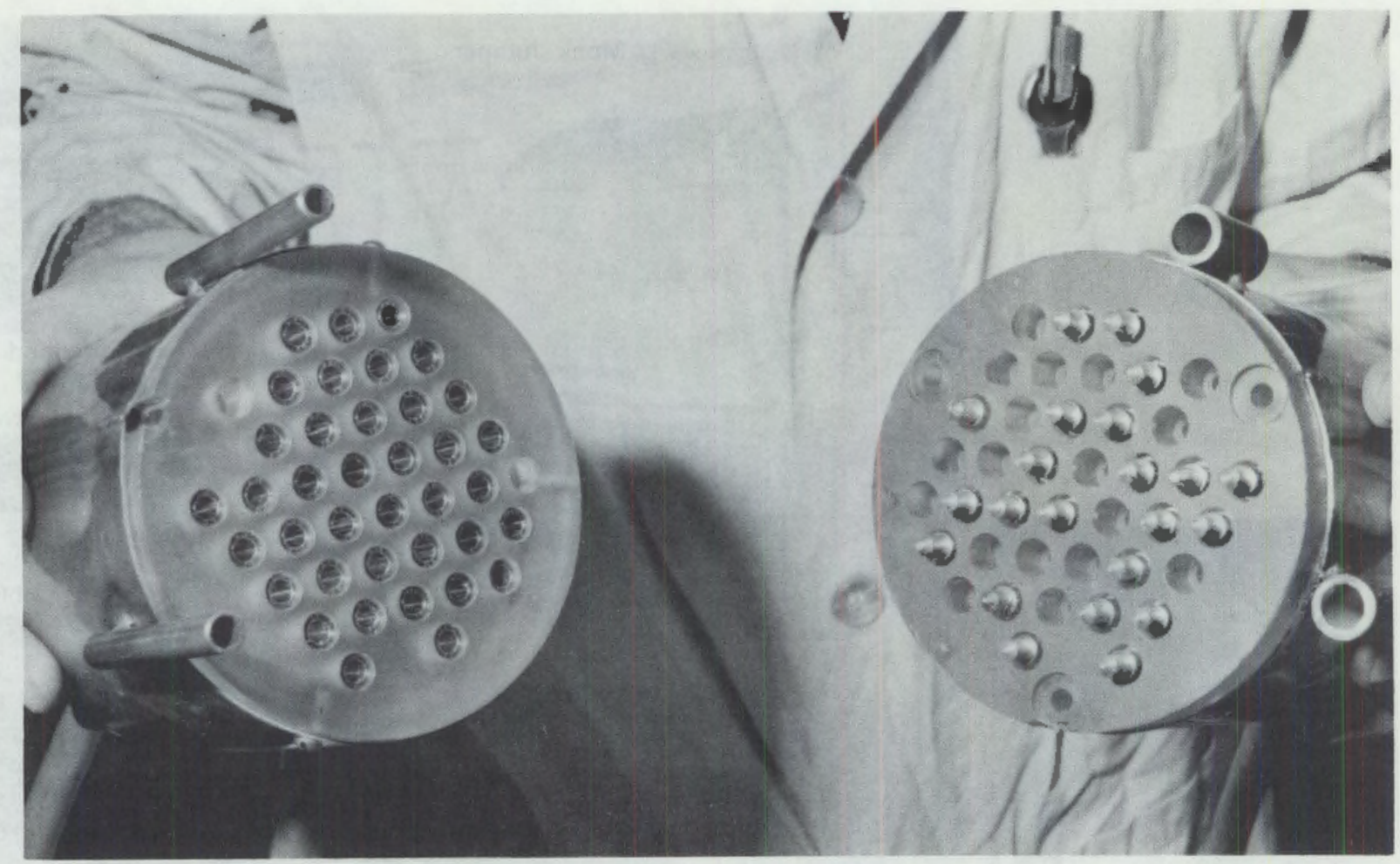

FIGURE 5-6. Television Signal Test Connector

using the two-camera cell-viewing system. Visual observations of both ease of the operation and pin survivability constituted the test data.

Pin wear resistance and thermocouple signal transmission were evaluated during repeated connections of the 10-pin instrument connector assembly inseries with the output leads of five thermocouples and a digital data logger. To verify results, the thermocouple signals were passed through the pins to the data logger where the signals are converted from $\mathrm{mV}$ to temperature in ${ }^{\circ} \mathrm{C}$ and recorded on magnetic tape. To determine the temperature data offset caused by the in-line pin assemblies, the thermocouple leads were split ahead of the connector, allowing the direct thermocouple signals to be recorded and compared to the indirect, through-pin signals. The offset, in ${ }^{\circ} \mathrm{C}$, was then calculated by subtracting the direct signal from the indirect signal. To assess the dependence of signal offset on signal magnitude, the five test thermocouples were placed within the discharge thermal mockup apparatus so as to read a range of temperatures from $25^{\circ} \mathrm{C}$ to $1050^{\circ} \mathrm{C}$. To evaluate pin wear resistance, the pin assemblies were disconnected, held apart for $\sim 1$ min and reconnected 20 times during the test. 
Electrical connector ampacity (current-carrying capacity) was evaluated using the 20 pin, $90 \mathrm{~A}$ per pin connector. The current and voltage drop across each pin were measured at power levels ranging from $0 \mathrm{~A}$ to $120 \mathrm{~A}$, allowing a calculation of overall pin/ socket/wire connection resistance. Thermocouples were located in the mock jumper and in the connector isolation plates to monitor internal temperatures during electrical operation. Prior to testing, the mock jumper was connected/removed five times. Initial testing consisted of operating the discharge lid power wires (using 16 of the 20 available pins) through the connector for 12 days with current ranging from $0 \mathrm{~A}$ to $110 \mathrm{~A}$. The connector was then removed and inspected for damage. Since some of the pins ran at only $15 \mathrm{~A}$, a second test was done at 20,60 , and $100 \mathrm{~A}$, two pins at a time. Finally, two pins were run at $120 \mathrm{~A}$ for a $16-\mathrm{h}$ period, after which the connector was quickly pulled apart and pin surface temperatures were measured.

The closed circuit TV signal connector was evaluated based on the quality of image on a TV monitor maintained by the electrical signal.

\subsection{RESULTS}

Results regarding the four different tests performed on the electrical, instrument, and TV connectors are discussed next in the following four subsections.

\subsubsection{Remotability of 40-Pin Instrument Connector}

The 40-pin instrument connector was chosen for remote testing because, having 40 pins, it represents the "worst case" for remote installation. The instrument connector jumper was installed at one end to a 40-pin wall flange and at the other end to the turntable.

Ouring initial connection of the jumper, some damage to the sockets was observed. The socket assemblies consist of a socket body, a contact interface band housed within the socket body, and a ferrule which holds the band in place (Figure 5-7). During initial connection, some relatively loose ferrules were displaced by the pins and crushed between the plastic isolation plates. The crushed ferrules were removed but not replaced. The connector was then reinstalled and removed with no further damage and all the contact interface bands remained within the sockets without the use of ferrules. 

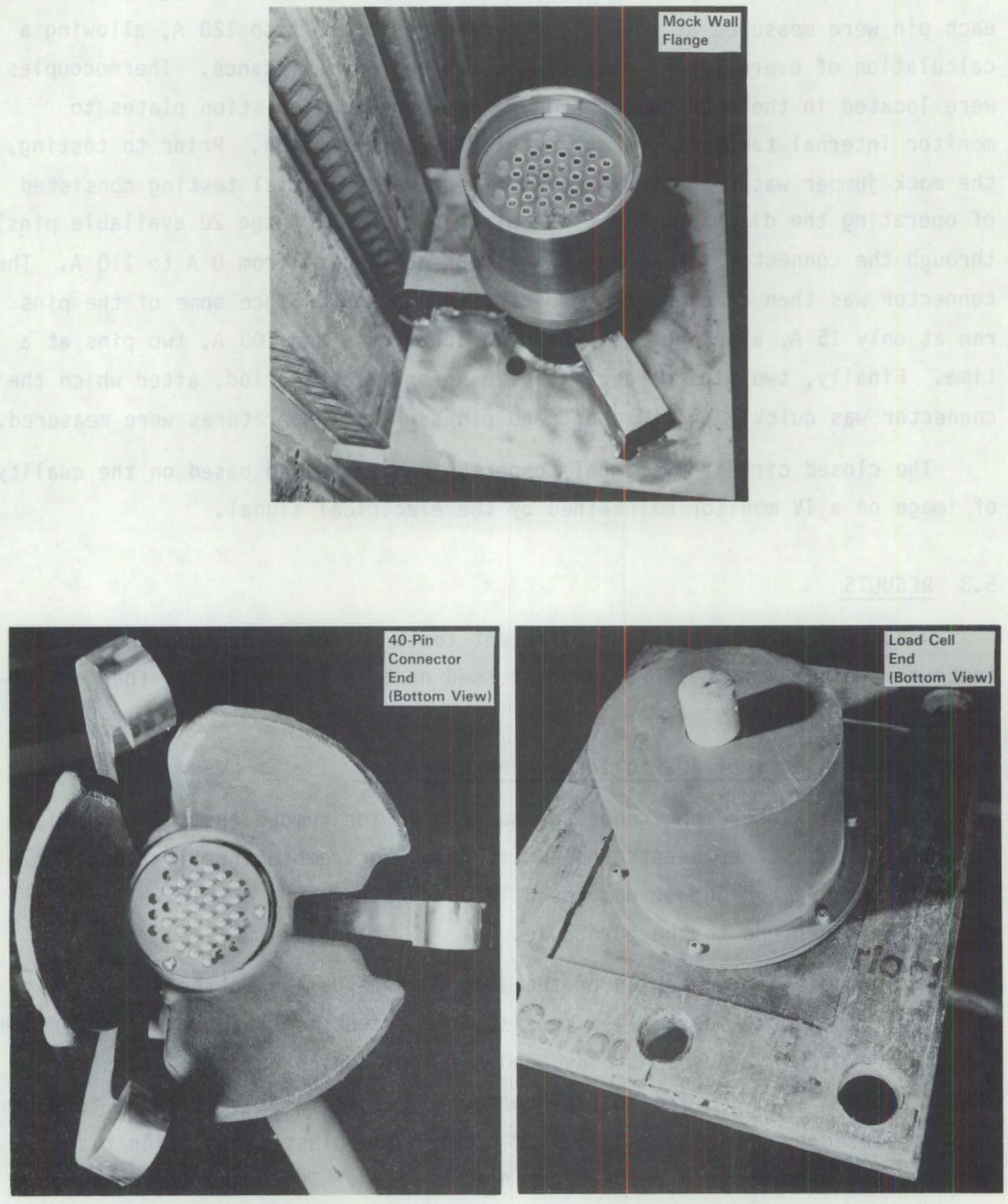

FIGURE 5-7. Socket Assemblies 
The jumper was then remotely removed and reconnected five additional times using the radio-controlled crane with direct operator viewing. The first two installations established that a crane-jiggling motion of the jumper is required until the pins and sockets match up and the connector falls into place.

Remote testing included removing and installing the connector using the crane and crane-held impact wrench an additional three times but with indirect closed-circuit camera viewing as would be done in-cell. All three completely remote operations were smooth and without difficulty.

As part of remote testing, strain-gauge load-cell signals were passed through five of the 40 pins in the connector. There were no difficulties associated with transmitting the load cell signal.

\subsubsection{Thermocouple Transmittance and Pin Wear Resistance of Instrument Connector}

The thermocouple transmittance and pin wear resistance data, consisting of temperature readings and offset values, is presented in Table 5-1. The data for the 10-pin version of the 40-pin instrument connector was collected "A" before disconnection and "B" right after reconnection. The testing was carried out over a 3-day period. The elapsed time between each connection/ reconnection iteration and the chronological time of each iteration during the test are also given in the table.

The temperature offsets were found to range between $-1.0^{\circ} \mathrm{C}$ to $+0.3^{\circ} \mathrm{C}$, with a mean value of $-0.237^{\circ} \mathrm{C}$ and a standard deviation of $0.02^{\circ} \mathrm{C}$. The number frequency distribution of the offsets is presented in Figure 5-8 in histogram form. In addition to mean and standard deviation, the distribution of offset values can be characterized by the parameters of skewness and kurtosis, which are an indication of the distribution's symmetry and flatness (or peakedness), respectively. The skewness of the offset value distribution was calculated as -2.58 , while the kurtosis was calculated as +14.76 . This distribution is more peaked than, and skewed to the right of a normal (gaussian) distribution, which has skewness and kurtosis values both equal 0 . Figures 5-9A through $5-9 c$ are plots of the temperature data corresponding to pins 1 through 5 recorded over a 40-min interval during the test. 


\section{TABLE 5-1. Multipin Instrument Connector Thermocouple Data}

REF. PROCEDURE HINP/WNSP QA05-09"t

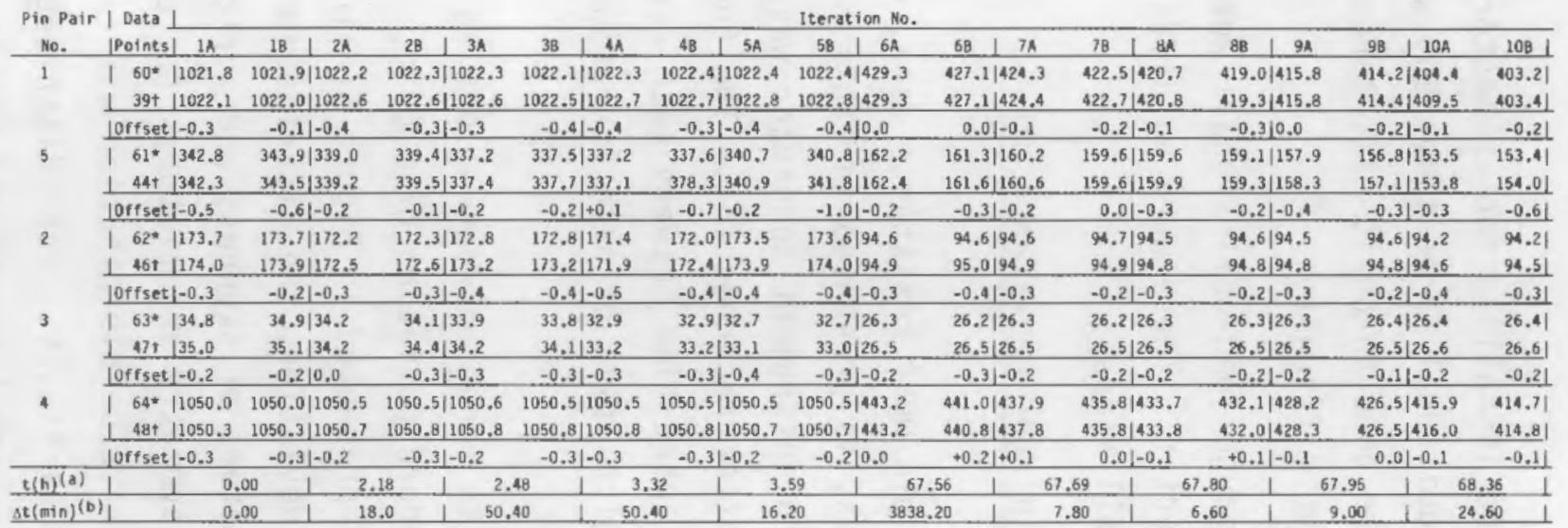

\begin{tabular}{|c|c|c|c|c|c|c|c|c|c|c|c|}
\hline No, & Doints $11 \mathrm{~A}$ & \begin{tabular}{l|l|l|}
$11 \mathrm{~B}$ & $12 \mathrm{~A}$ \\
\end{tabular} & \begin{tabular}{l|l|l}
$28 B$ & $13 A$ \\
\end{tabular} & \begin{tabular}{l|l|l|}
$13 B$ & $14 A$ \\
\end{tabular} & $14 \mathrm{~B} / 15 \mathrm{~A}$ & \begin{tabular}{l|l|l|}
$15 B$ & $16 A$ \\
\end{tabular} & \begin{tabular}{l|l|}
$16 \mathrm{~B}$ & $17 \mathrm{~A}$
\end{tabular} & \begin{tabular}{l|l|}
178 & $18 \mathrm{~A}$ \\
\end{tabular} & \begin{tabular}{l|l|}
$18 B$ & $19 A$ \\
\end{tabular} & \begin{tabular}{|l|l|}
198 & $20 A$ \\
\end{tabular} & 208 \\
\hline \multirow[t]{3}{*}{1} & $160^{*} \mid 402.2$ & $401.0 \mid 384.0$ & $383.2 \mid 382.5$ & $\ldots-1380.6$ & $379.9 \mid 378.9$ & $378.5 \mid 373,1$ & $372.7 \mid 358.3$ & $358.0 \mid 357.1$ & $356.7 \mid 355.5$ & $355.1 \mid 354.5$ & 354.21 \\
\hline & $1 \quad 39+[402.2$ & $401.3 \mid 384.1$ & $383.3 \mid 382.7$ & $\ldots 1380.8$ & 380.21379 .1 & $378.6 \mid 373,5$ & 373.01358 .5 & $358.2 \mid 358.3$ & $356,9 \mid 355,6$ & 355.31354 .8 & 354.51 \\
\hline & Loffset $\mid 0.0$ & $-0,3\}-0,1$ & $+0.1 \mid-0.2$ & $\cdots 1-0.2$ & $-0.3 \mid-0.2$ & $0.11-0.4$ & $-0.3 \mid-0.2$ & $-0.2 i-0.2$ & $-0.21-0.1$ & $-0.21-0.3$ & $-0.3 i$ \\
\hline \multirow[t]{3}{*}{5} & | $61^{*} \mid 152,1$ & $152.8 \mid 146.9$ & $146.6 \mid 145.2$ & $\cdots \mid 145.5$ & $145.3 / 145.3$ & $144.7 \mid 138.1$ & $137.4 \mid 133.1$ & $132.5 \mid 133.6$ & $134.3 \mid 133.8$ & $132.8 \mid 131.5$ & 130.21 \\
\hline & $\perp 44 t \mid 152.2$ & 153.31147 .1 & $146.7] 145.6$ & $\ldots 145.6$ & $145.6] 145.4$ & $144.7 \mid 138.5$ & $137.6] 133.4$ & $132.7] 133.9$ & 134.51134 .2 & 133.21131 .7 & 130.61 \\
\hline & $10 \mathrm{ffset}-0.1$ & $-0.51-0.2$ & $-0.1 \mid-0.4$ & $=-0.1$ & $-0.3 \mid-0.1$ & $0.0[-0.4$ & $-0.21-0.3$ & $-0.21-0.3$ & $-0.2 t-0.4$ & $-0.41-0.2$ & -0.41 \\
\hline \multirow[t]{3}{*}{2} & $\left|\quad 62^{*}\right| 94.3$ & $94.2 \mid 93.7$ & $93.6 \mid 93.6$ & $\cdots \mid 93.4$ & $93.4 \mid 93.4$ & $93.3 \mid 93.0$ & $93.0 \mid 91.3$ & $91.3 \mid 91.3$ & $91.3 \mid 91.2$ & $91.1 \mid 90.9$ & 90.91 \\
\hline & $\perp \quad 46+\mid 94.6$ & $94,5194,0$ & $93.9 \mid 93.8$ & $\ldots-93.7$ & $93.6] 93.6$ & $93.6\} 93.3$ & 93.3191 .6 & $91.6 \mid 91.6$ & $91.6 \mid 91.4$ & $91.3 \mid 91.2$ & 91.21 \\
\hline & Juffset $1-0,3$ & $-0.3 \mid-0.3$ & $-0.3 \mid-0.2$ & $\cdots-0.3$ & $-0.2 \mid-0.2$ & $-0.31-0.3$ & $-0.31-0.3$ & $-0.3 \mid-0.3$ & $-0,31-0,2$ & $-0.2\}-0.3$ & -0.31 \\
\hline \multirow[t]{3}{*}{3} & | $63^{*} \mid 26.4$ & $26.5 \mid 26.6$ & $26.6 \mid 26.6$ & $--\mid 26.6$ & $26.7 \mid 26.7$ & $26.8 \mid 26.6$ & $26.6 \mid 26.7$ & $26.7 \mid 26.7$ & $26.7 \mid 26.7$ & $26.8 \mid 26.7$ & 26.71 \\
\hline & $\perp$. 17.126 .6 & $26.6 \mid 26.9$ & $26.8126,9$ & $\ldots 126.9$ & 26.9126 .9 & $26.9 \mid 26.8$ & $26,8 \mid 26,9$ & $26.9] 26.9$ & $27.0 \mid 27.0$ & $27.0 \mid 27.0$ & 27,01 \\
\hline & 10 ffset $\mid-0.2$ & $-0,11-0.3$ & $-0.2 j-0.3$ & $=-0,3$ & $-0.21-0.2$ & $-0,1 \mid-0.2$ & $-0.21-0.2$ & $-0.2 \mid-0.2$ & $-0,3 \mid-0,3$ & $-0.21-0.3$ & -0.31 \\
\hline \multirow[t]{3}{*}{4} & $|64 *| 413.5$ & $412.2 \mid 394.0$ & $393.2 \mid 392.4$ & $--\mid 390.8$ & 390.21289 .0 & $388.4 \mid 382.7$ & $382.3 \mid 366.8$ & $366.5 / 365.5$ & $365.1 \mid 363.7$ & $363.1 \mid 362.9$ & 362.41 \\
\hline & $\perp \quad 48+\quad 1413.5$ & $412.4 / 394.2$ & 393.31392 .5 & $\ldots 390.9$ & $390.4 \mid 389.2$ & $386.6 \mid 382.9$ & 282.51367 .0 & $366,7] 365,6$ & $365.3 / 364.0$ & $363.4 \mid 363.1$ & 362.71 \\
\hline & Ooffset 10.0 & $-0.21-0.2$ & $-0,1 \mid-0.1$ & $\ldots-0.1$ & $-0.21-0.2$ & $-0,2 \mid-0.2$ & $-0.2]-0.2$ & $-0.21-0.1$ & $-0.21-0.3$ & $-0.31-0.2$ & -0.31 \\
\hline$j^{(a)}$ & & & 69,44 & & & & \begin{tabular}{l|l}
.02 & 1 \\
\end{tabular} & 71 & 71,18 & 71.31 & 71.38 \\
\hline$(\min )^{(t)}$ & & 00 & $.00 \quad 1$ & 1 & , & .60 & 1,60 & $64.2 \quad 1$ & 5.40 & $\begin{array}{l}7.80 \quad 1 \\
\end{array}$ & 4.20 \\
\hline
\end{tabular}

Data taken from lab notebook BNW 50344 pp. 80-99.

- Signal passed through pin.

(a) Rererence signal.

(b) Time between iterations. 


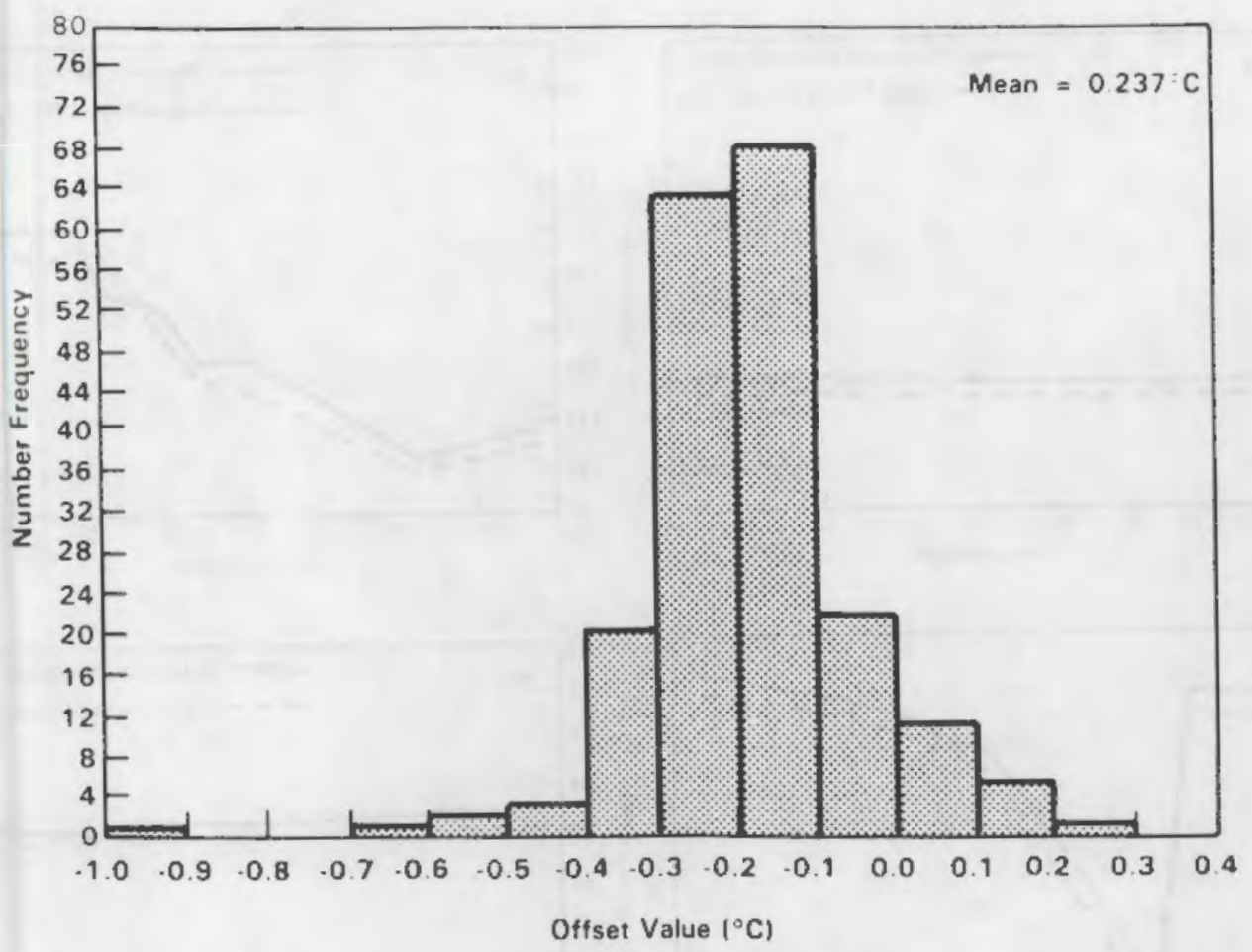

FIGURE 5-8. Number Frequency Distribution of Thermocouple offset Values

The temperature data presented in Table 5-1 was analyzed to determine whether the offset values were dependent upon the number of times the test connector was reconnected (iteration number), the temperature being measured, or dependent upon the pin being used for measurement.

The mean offset for each connection/reconnection cycle are given in Table 5-2. These mean values are plotted in Figure 5-10. Straight lines were fitted to the data in logical temperature/iteration groups as shown, as are the equations for these fitted lines. Since the slopes of all four lines are less than 0.04 , it can be concluded that of fset is not dependent on iteration number, and that the intercept values suggest only a weak temperature dependence.

The mean offsets corresponding to six temperature ranges over all iterations are given in Table 5-3. These mean offsets are plotted in Figure 5-11. The lack of a trend in this plot further suggests that of fset is not dependent on the temperature being measured. 

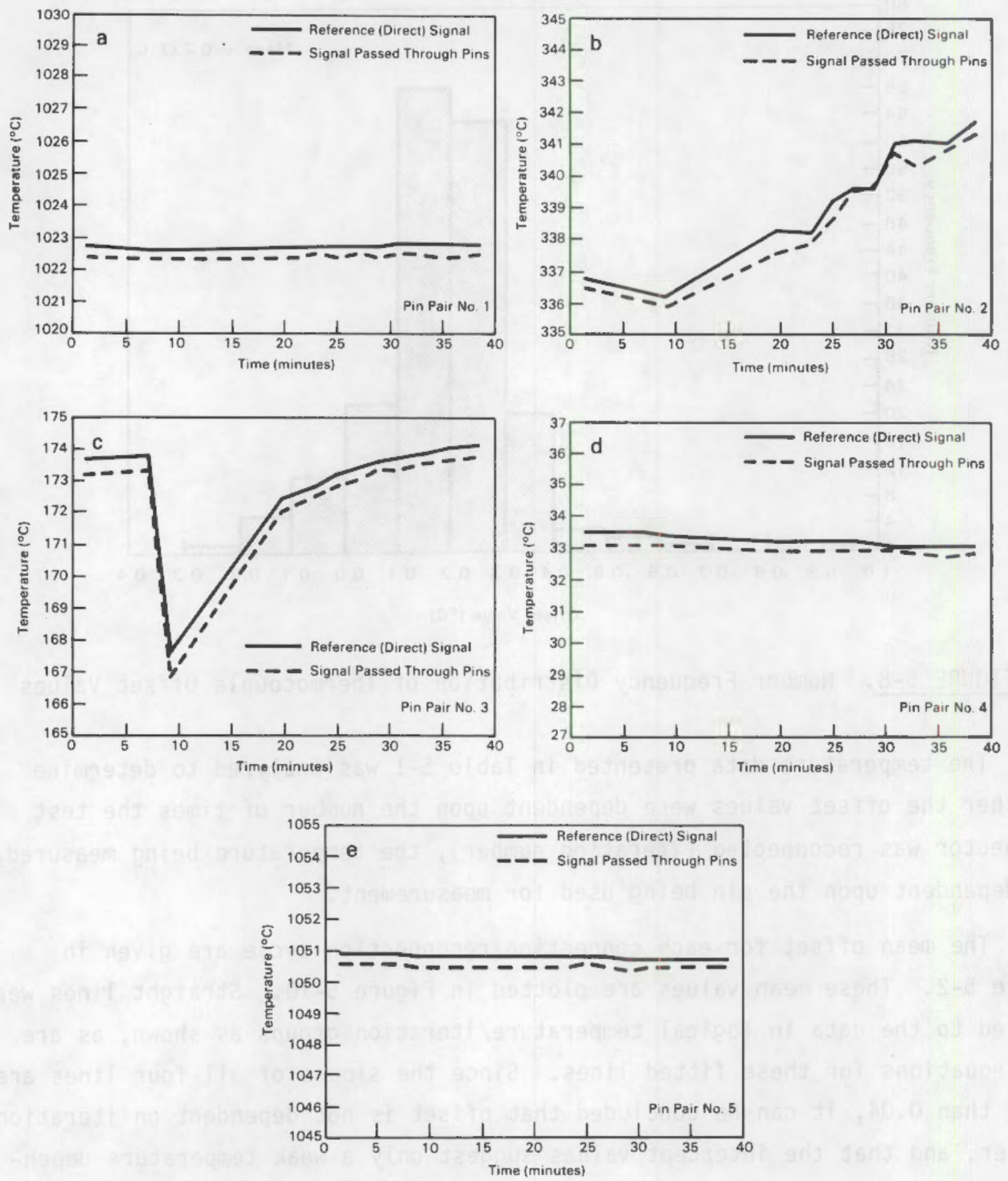

FIGURE 5-9. Pin Pair Temperature Data Plot 
TABLE 5-2. Mean Offset as a Function of Iteration No. Iteration No. Mean Offset Mean Temp.

$1 \mathrm{~A}$

$1 B / 2 A$

$2 B / 3 A$

$3 B / 4 A$

$4 B / 5 A$

$6 B / 7 \mathrm{~A}$

$7 \mathrm{~B} / 8 \mathrm{~A}$

$8 B / 9 \mathrm{~A}$

$9 B / 10 A$

$10 \mathrm{~B} / 11 \mathrm{~B}$

$11 B / 12 A$

$12 B / 13 A$

$14 B / 15 A$

$15 B / 16 A$

$16 B / 17 \mathrm{~A}$

$17 \mathrm{~B} / 18 \mathrm{~A}$

$18 \mathrm{~B} / 19 \mathrm{~A}$

198/20A
$-0.32$

$-0.25$

$-0.27$

$-0.30$

$-0.36$

$-0.15$

$-0.16$

$-0.18$

$-0.19$

$-0.20$

$-0.25$

$-0.18$

$-0.21$

$-0.20$

$-0.24$

$-0.22$

$-0.25$

$-0.26$
524.7

524.4

523.8

523.4

527.9

229.5

227.5

225.5

222.0

218.2

213.4

208.5

207.1

204.7

199.1

195.2

194.8

193.8

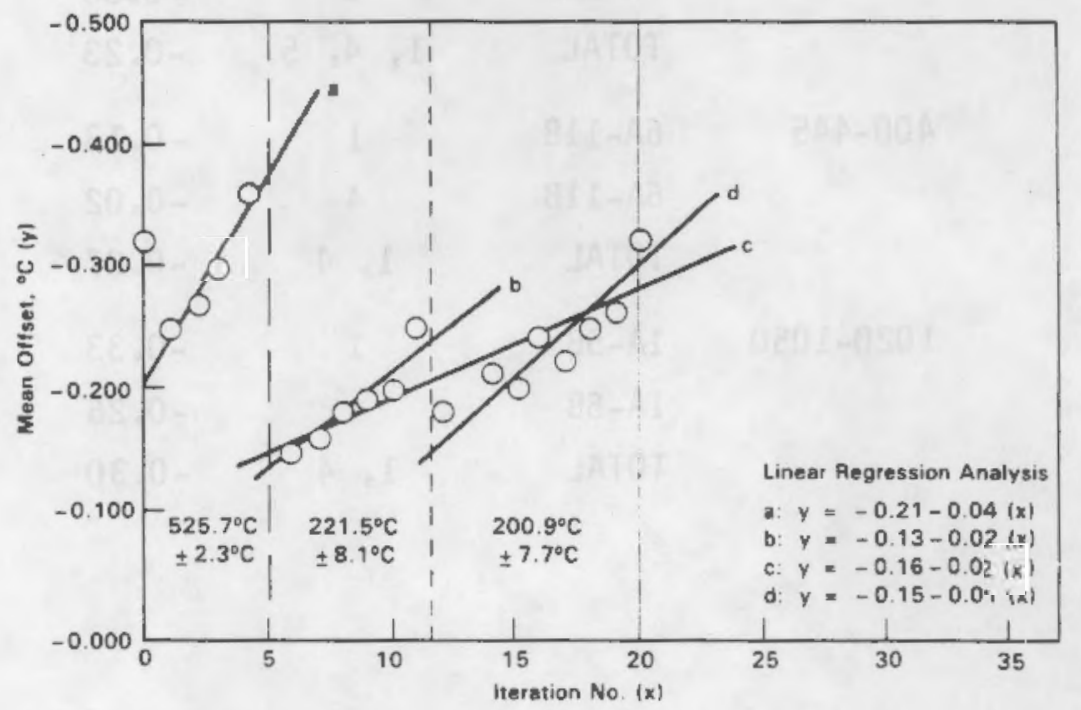

FIGURE $5-10$. Mean Of $f$ set as a Function of Iteration Number 
The mean offsets corresponding to each pin at fairly constant temperature are given in Table 5-4. These mean offsets are plotted in Figure 5-12. Due to the random scatter of these dots, it is concluded that, while offset is not a function of temperature, it is a function of the pin being used.

The temperature offset data in Figure 5-13 are plotted corresponding to pin pair No. 3 , which was held at constant temperature $\left(30.8^{\circ} \mathrm{C} \pm 4.3^{\circ} \mathrm{C}\right)$ throughout all iterations. This plot makes more certain the conclusion that offset is invariant with pin disconnection/reconnection, even after 20 such cycles.

TABLE 5-3. Mean offset as a Function of Temperature Measured

\begin{tabular}{|c|c|c|c|c|}
\hline Temp. ${ }^{\circ} \mathrm{C}$ & Iteration & Pin No. & $\begin{array}{r}\text { Mean } \\
\text { of f set, }{ }^{\circ} \mathrm{C} \\
\end{array}$ & N \\
\hline $25-35^{\circ} \mathrm{C}$ & $1 A-20 B$ & 3 & -0.23 & 39 \\
\hline $90-100^{\circ} \mathrm{C}$ & $6 A-20 B$ & 2 & -0.30 & 29 \\
\hline \multirow[t]{3}{*}{$120-200^{\circ} \mathrm{C}$} & $6 A-20 B$ & 5 & -0.26 & 29 \\
\hline & $1 A-5 B$ & 2 & -0.36 & 10 \\
\hline & TOTAL & $2 \& 5$ & -0.29 & 39 \\
\hline \multirow[t]{4}{*}{$335-395$} & $12 A-20 B$ & 1 & -0.19 & 17 \\
\hline & $12 A-20 B$ & 4 & -0.19 & 17 \\
\hline & $1 A-5 B$ & 5 & -0.38 & 10 \\
\hline & TOTAL & $1,4,5$ & -0.23 & 44 \\
\hline \multirow[t]{3}{*}{$400-445$} & $6 A-11 B$ & 1 & -0.13 & 12 \\
\hline & $6 A-11 B$ & 4 & -0.02 & 12 \\
\hline & TOTAL & 1,4 & -0.07 & 24 \\
\hline \multirow[t]{3}{*}{$1020-1050$} & $1 A-5 B$ & 1 & -0.33 & 10 \\
\hline & $1 A-5 B$ & 4 & -0.26 & 10 \\
\hline & TOTAL & 1,4 & -0.30 & 20 \\
\hline
\end{tabular}




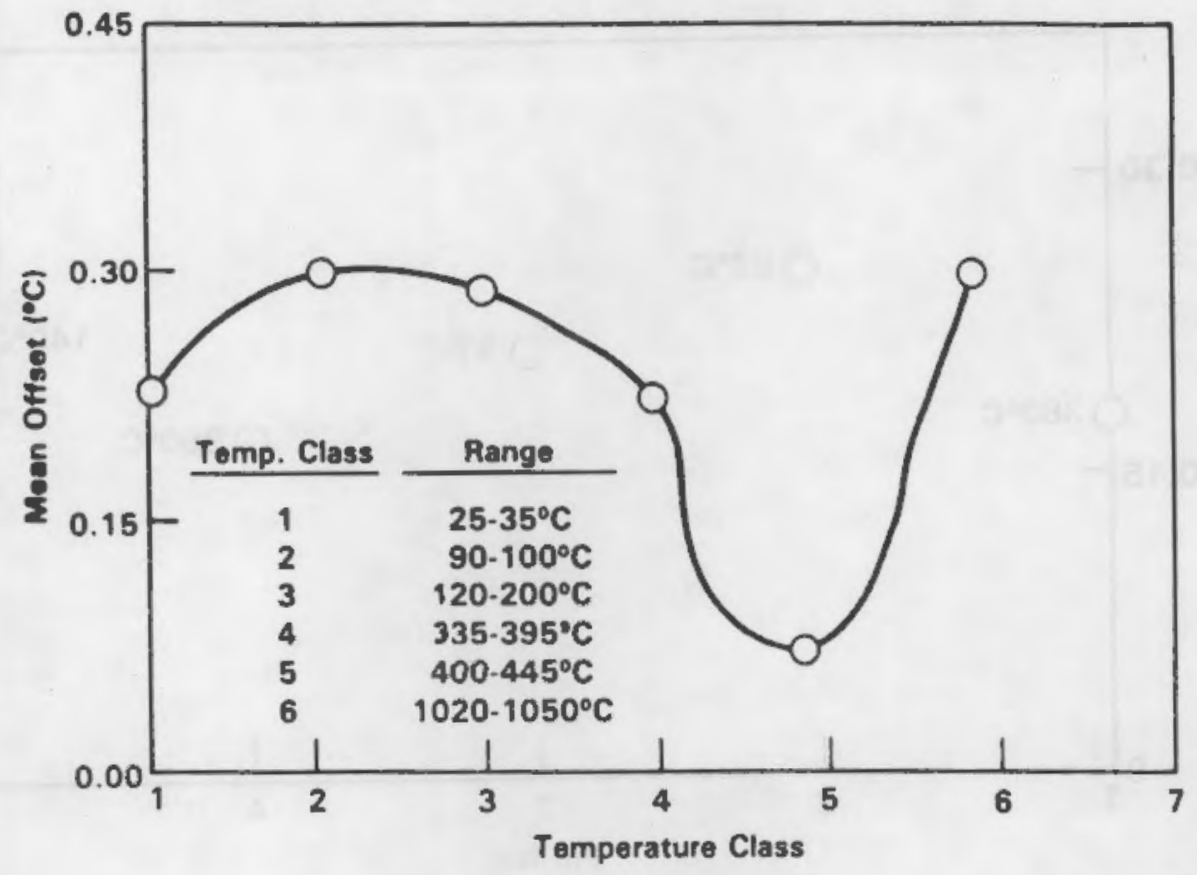

FIGURE 5-11. Mean Offset as a Function of Temperature Measured

TABLE 5-4. Mean Offset as a Function of Connector Pin

\begin{tabular}{|c|c|c|c|c|}
\hline Temperature & Pin No. & Iteration & $\begin{array}{r}\text { Mean } \\
\text { Offset, }{ }^{\circ} \mathrm{C} \\
\end{array}$ & N \\
\hline $402-354$ & 1 & $11 \mathrm{~A}-20 \mathrm{~B}$ & -0.18 & 19 \\
\hline $94.3-90.9$ & 2 & $11 A-20 B$ & -0.27 & 19 \\
\hline $26.6-27.0$ & 3 & $11 A-20 B$ & -0.23 & 19 \\
\hline $413.5-362.7$ & 4 & $11 \mathrm{~A}-20 \mathrm{~B}$ & -0.18 & 19 \\
\hline $152.2-130.6$ & 5 & $11 A-20 B$ & -0.25 & 19 \\
\hline
\end{tabular}

\subsubsection{Ampacity of 20-Pin, 90 Amp per Pin Power Connector}

The pin numbering system for the 20-pin isolation plate used in the test connector are shown in Figure 5-2. Note pins $4 \mathrm{~A}$ and 7 are nearest the thermocouple. Table 5-5 shows test data regarding pins $4 \mathrm{~A}$ and 7 with amperage ranging from $20 \mathrm{~A}$ to $120 \mathrm{~A}$. The voltage readings refer to the voltage drop across the pin/socket assemblies and $27 \mathrm{ft}$ of AWG \#4 wire. The total resistance of the wire and pins is calculated based on the ampere and voltage readings while the resistance of the wire, based on wire manufacturer data $0.364 \Omega$ per 


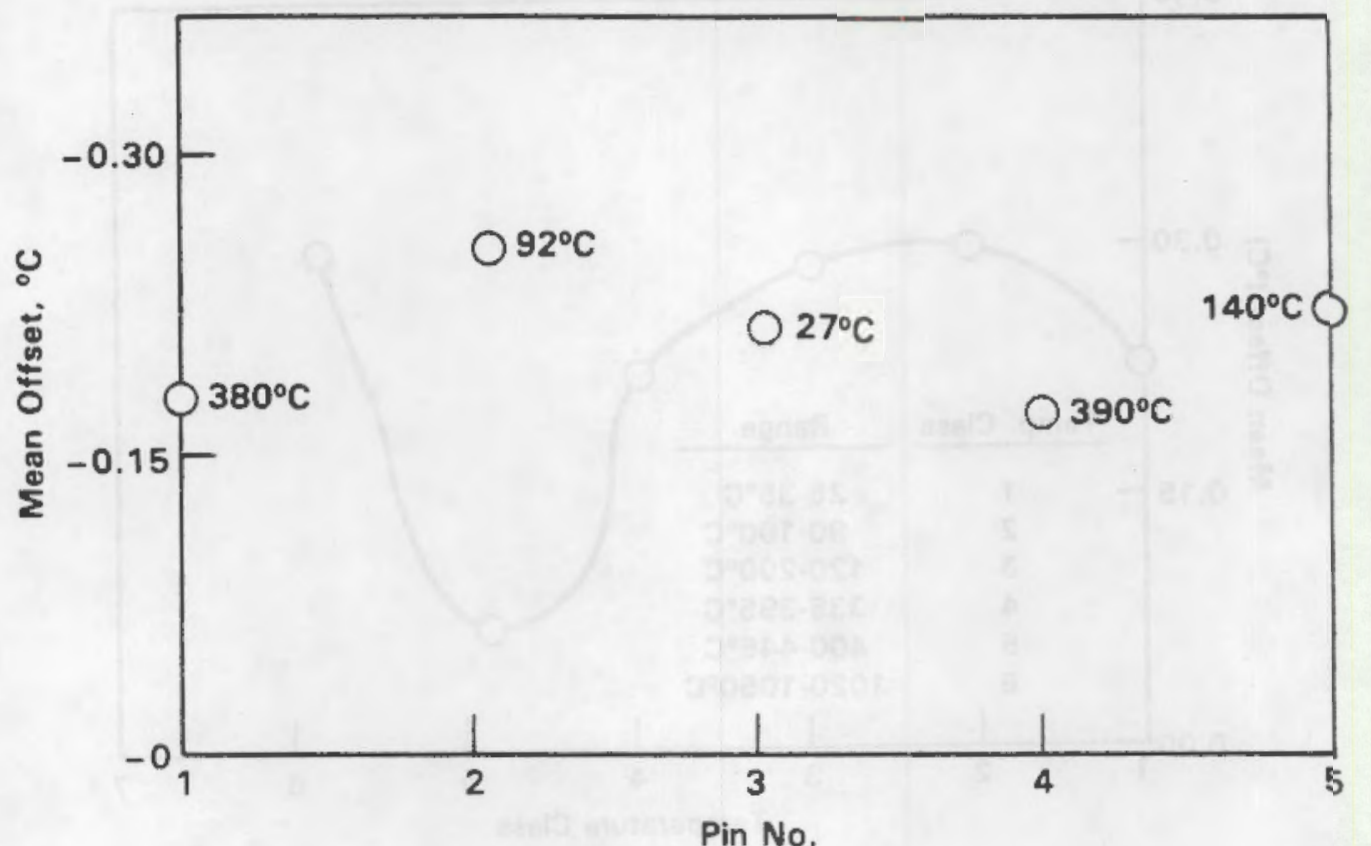

FIGURE 5-12. Mean Offset as a Function of Iteration at Constant Temperature

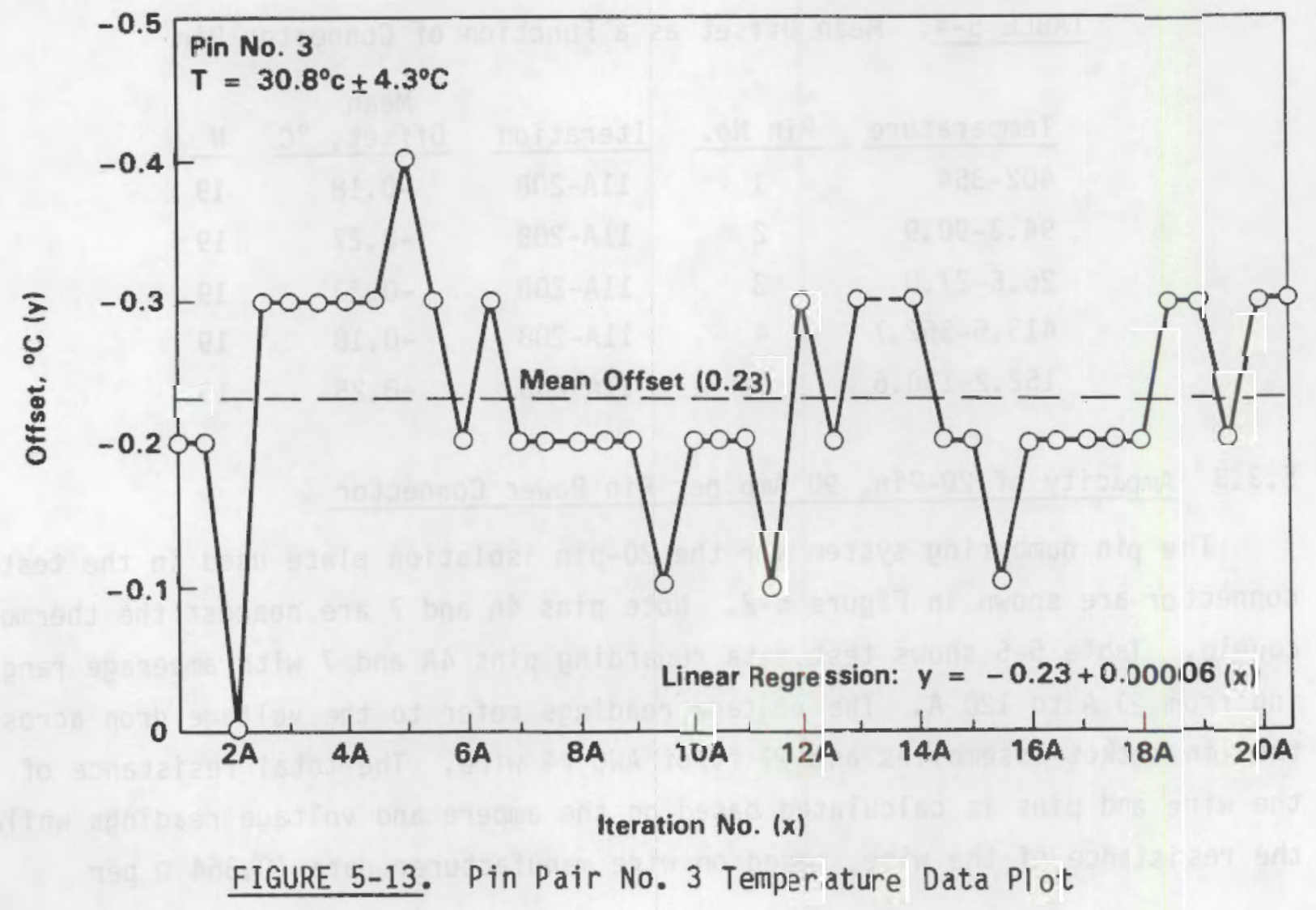


$1000 \mathrm{ft}$ ), is subtracted to arrive at the contact resistance. The temperatures are those measured using a thermocouple embedded in the radiation-resistant plate material (located as shown in Figure 5-2). The power loss due to the contact resistance is given in Table 5-5.

After $16 \mathrm{~h}$ at $120.51 \mathrm{~A}$, power was turned off and the connector was quickly disconnected to measure pin surface temperatures. The surface temperature of pins 7 and $4 \mathrm{~A}$ was measured as $65.3^{\circ} \mathrm{C}$, on $1 \mathrm{y} 3.7^{\circ} \mathrm{C}$ higher than the plate temperatures. No damage, e.g., melting of the plate material, was observed. At the rated amperage, $90 \mathrm{~A}$, the pin power loss is between $78 \mathrm{~W}$ and $88 \mathrm{~W} / \mathrm{pin}$ for a total average power loss in a $20 \mathrm{pin}, 90 \mathrm{~A}$ per pin connector of $1660 \mathrm{~W}$. At $120 \mathrm{~A}$, the pin power loss is between $126 \mathrm{~W}$ and $138 \mathrm{~W}$, for a total 20-pin connector loss of $2640 \mathrm{~W}$. The temperature of the isolation material near the pins corresponding to $90 \mathrm{~A}$ and $120 \mathrm{~A}$ operation is $40^{\circ} \mathrm{C}$ and $60^{\circ} \mathrm{C}$, respectively. Whether a $20 \mathrm{pin}, 90 \mathrm{~A}$ per pin connector can dissipate $1660 \mathrm{~W}$ at a temperature below the fiberglass plate damage threshold is unknown. The temperature at which damage, in the form of softening or even melting, occurs is not known. If heat dissipation is found to be a problem, it may be necessary to replace the plastic-based plate material with a higher temperature (up to $1000^{\circ} \mathrm{C}$ ), machinable ceramic material. Alternately, air cooling can be easily supplied to the connector by routing air through the jumper itself.

Another important parameter is the method by which the wires are connected to the pins and sockets. In the test connector, wires were crimped into threaded connectors which were then screwed into the pins and sockets. A different method, e.g., soldering, may result in better electrical contact with lower contact resistance and thus less connector heating.

A plot of average values of the data in Table 5-5 shows pin resistance, and connector temperature as a function of pin power loss (Figure 5-14). The data reveals an unexpected result in that pin resistance decreases as temperature increases. No change in resistance would be anticipated since material resistivity changes very little over the $\sim 40^{\circ} \mathrm{C}$ 
TABLE 5-5. Pin Resistance, Power Generation, and Temperature Data

\begin{tabular}{|c|c|c|c|c|c|c|c|}
\hline $\begin{array}{l}\text { Pin } \\
\text { No. }\end{array}$ & $\begin{array}{c}\Delta V \\
\text { Volts } \\
\end{array}$ & $\begin{array}{c}\text { I } \\
\text { Amps } \\
\end{array}$ & $\begin{array}{c}R_{\text {total }} \\
10^{-2} \text { ohms } \\
\end{array}$ & $\begin{array}{c}\text { Rpin } \\
10^{-2} \text { ohms } \\
\end{array}$ & Loss, Watts & $\begin{array}{l}\text { Pin Power } \\
\text { Connector } \\
\text { Temp. },{ }^{\circ} \mathrm{C} \\
\end{array}$ & $\begin{array}{c}\text { Elapsed } \\
\text { Time, min. }\end{array}$ \\
\hline $\begin{array}{r}4 A \\
7\end{array}$ & $\begin{array}{l}0.61 \\
0.61\end{array}$ & $\begin{array}{l}20.5 \\
20.5\end{array}$ & $\begin{array}{l}2.98 \\
2.98\end{array}$ & $\begin{array}{l}2.00 \\
2.00\end{array}$ & $\begin{array}{l}8.4 \\
8.4\end{array}$ & 23.4 & 0 \\
\hline $\begin{array}{r}4 A \\
7\end{array}$ & $\begin{array}{l}1.00 \\
1.04\end{array}$ & $\begin{array}{l}29.98 \\
39.98\end{array}$ & $\begin{array}{l}2.50 \\
2.60\end{array}$ & $\begin{array}{l}1.52 \\
1.62\end{array}$ & $\begin{array}{l}13.7 \\
25.9\end{array}$ & 24.6 & 32 \\
\hline $\begin{array}{r}4 A \\
7\end{array}$ & $\begin{array}{l}1.63 \\
1.73\end{array}$ & $\begin{array}{l}79.93 \\
79.93\end{array}$ & $\begin{array}{l}2.04 \\
2.16\end{array}$ & $\begin{array}{l}1.06 \\
1.18\end{array}$ & $\begin{array}{l}67.7 \\
75.4\end{array}$ & 30.3 & 56 \\
\hline $\begin{array}{r}4 A \\
7\end{array}$ & $\begin{array}{l}1.63 \\
1.73\end{array}$ & $\begin{array}{l}79.95 \\
79.95\end{array}$ & $\begin{array}{l}2.04 \\
2.16\end{array}$ & $\begin{array}{l}1.06 \\
1.18\end{array}$ & $\begin{array}{l}67.8 \\
75.4\end{array}$ & 31.8 & 67 \\
\hline $\begin{array}{r}4 A \\
7\end{array}$ & $\begin{array}{l}1.64 \\
1.73\end{array}$ & $\begin{array}{l}79.90 \\
79.90\end{array}$ & $\begin{array}{l}2.05 \\
2.17\end{array}$ & $\begin{array}{l}1.07 \\
1.19\end{array}$ & $\begin{array}{l}68.3 \\
76.0\end{array}$ & 35.0 & 118 \\
\hline $\begin{array}{r}4 A \\
7\end{array}$ & $\begin{array}{l}1.64 \\
1.73\end{array}$ & $\begin{array}{l}79.91 \\
79.91\end{array}$ & $\begin{array}{l}2.05 \\
2.16\end{array}$ & $\begin{array}{l}1.07 \\
1.18\end{array}$ & $\begin{array}{l}68.3 \\
75.4\end{array}$ & 35.3 & 128 \\
\hline $4 \mathrm{~A}$ & 1.75 & 89.97 & 1.95 & 0.97 & 78.5 & 37.4 & 152 \\
\hline 7 & 1.85 & 89.97 & 2.06 & 1.08 & 87.4 & & \\
\hline $4 \mathrm{~A}$ & 1.75 & 90.10 & 1.94 & 0.96 & 77.9 & 38.9 & 177 \\
\hline 7 & 1.85 & 90.10 & 2.05 & 1.07 & 86.9 & & \\
\hline $4 \mathrm{~A}$ & 1.76 & 90.10 & 1.95 & 0.97 & 78.7 & 40.3 & 216 \\
\hline $\begin{array}{r}7 \\
4 A\end{array}$ & 1.86 & $\begin{array}{r}90.10 \\
0\end{array}$ & 2.06 & 1.08 & 87.7 & & \\
\hline 7 & $\begin{array}{l}1.93 \\
2.05\end{array}$ & $\begin{array}{l}100.12 \\
100.12\end{array}$ & $\begin{array}{l}1.93 \\
2.05\end{array}$ & $\begin{array}{l}0.95 \\
1.07\end{array}$ & $\begin{array}{r}95.2 \\
107.3\end{array}$ & 40.8 & 229 \\
\hline $\begin{array}{r}4 A \\
7\end{array}$ & $\begin{array}{l}1.94 \\
2.05\end{array}$ & $\begin{array}{l}100.10 \\
100.10\end{array}$ & $\begin{array}{l}1.94 \\
2.05\end{array}$ & $\begin{array}{l}0.96 \\
1.07\end{array}$ & $\begin{array}{r}96.2 \\
107.2\end{array}$ & 44.1 & 270 \\
\hline $\begin{array}{r}4 A \\
7\end{array}$ & $\begin{array}{l}1.95 \\
2.06\end{array}$ & $\begin{array}{l}100.10 \\
100.10\end{array}$ & $\begin{array}{l}1.95 \\
2.06\end{array}$ & $\begin{array}{l}0.97 \\
1.08\end{array}$ & $\begin{array}{r}97.2 \\
108.2\end{array}$ & 45.2 & 312 \\
\hline $4 A$ & 1.95 & 100.11 & 1.95 & 0.97 & 97.2 & 47.2 & 1297 \\
\hline 7 & 2.04 & 100.11 & 2.04 & 1.06 & 106.2 & & \\
\hline $\begin{array}{r}4 A \\
7\end{array}$ & $\begin{array}{l}2.03 \\
2.11\end{array}$ & $\begin{array}{l}105.1 \\
105.1\end{array}$ & $\begin{array}{l}1.93 \\
2.01\end{array}$ & $\begin{array}{l}0.95 \\
1.03\end{array}$ & $\begin{array}{l}104.9 \\
113.8\end{array}$ & 48.7 & 1348 \\
\hline $4 \mathrm{~A}$ & 2.10 & 109.9 & 1.91 & 0.93 & 112.3 & 50.4 & 1399 \\
\hline 7 & 2.18 & 109.9 & 1.98 & 1.00 & 120.8 & & כנד \\
\hline $\begin{array}{r}4 A \\
7\end{array}$ & $\begin{array}{l}2.09 \\
2.18\end{array}$ & $\begin{array}{l}109.8 \\
109.8\end{array}$ & $\begin{array}{l}1.90 \\
1.99\end{array}$ & $\begin{array}{l}0.92 \\
1.01\end{array}$ & $\begin{array}{l}110.9 \\
121.8\end{array}$ & 50.8 & 1446 \\
\hline $\begin{array}{r}4 A \\
7\end{array}$ & $\begin{array}{l}2.16 \\
2.26\end{array}$ & $\begin{array}{l}115.61 \\
115.61\end{array}$ & $\begin{array}{l}1.87 \\
1.95\end{array}$ & $\begin{array}{l}0.89 \\
0.97\end{array}$ & $\begin{array}{l}119.0 \\
129.6\end{array}$ & 57.9 & 1489 \\
\hline $4 \mathrm{~A}$ & 2.17 & 115.5 & 1.88 & 0.9 & 120.1 & 53.6 & 1525 \\
\hline 7 & 2.26 & 115.5 & 1.96 & 0. & 130.7 & & \\
\hline $\begin{array}{r}4 A \\
7\end{array}$ & 2.16 & 115.3 & 1.87 & $\begin{array}{r}0.89 \\
0.07\end{array}$ & 118.3 & 54.4 & 1598 \\
\hline $4 A$ & $\begin{array}{l}2.25 \\
2.23\end{array}$ & $\begin{array}{l}115.3 \\
119.9\end{array}$ & 1.86 & 0.88 & 126.5 & 56.5 & 1709 \\
\hline 7 & 2.32 & 119.9 & 1.93 & 0.95 & 136.6 & 00.0 & 1709 \\
\hline $\begin{array}{r}4 \mathrm{~A} \\
7\end{array}$ & $\begin{array}{l}2.23 \\
2.32\end{array}$ & $\begin{array}{l}119.8 \\
119.8\end{array}$ & $\begin{array}{l}1.86 \\
1.94\end{array}$ & $\begin{array}{l}0.88 \\
0.96\end{array}$ & $\begin{array}{l}126.3 \\
137.8\end{array}$ & 56.8 & 1718 \\
\hline $\begin{array}{r}4 A \\
7\end{array}$ & 2.29 & 120.51 & 1.90 & 0.92 & 133.6 & 61.6 & 2728 \\
\hline 7 & 2.33 & 120.51 & 1.93 & 0.95 & 138.0 & & \\
\hline
\end{tabular}




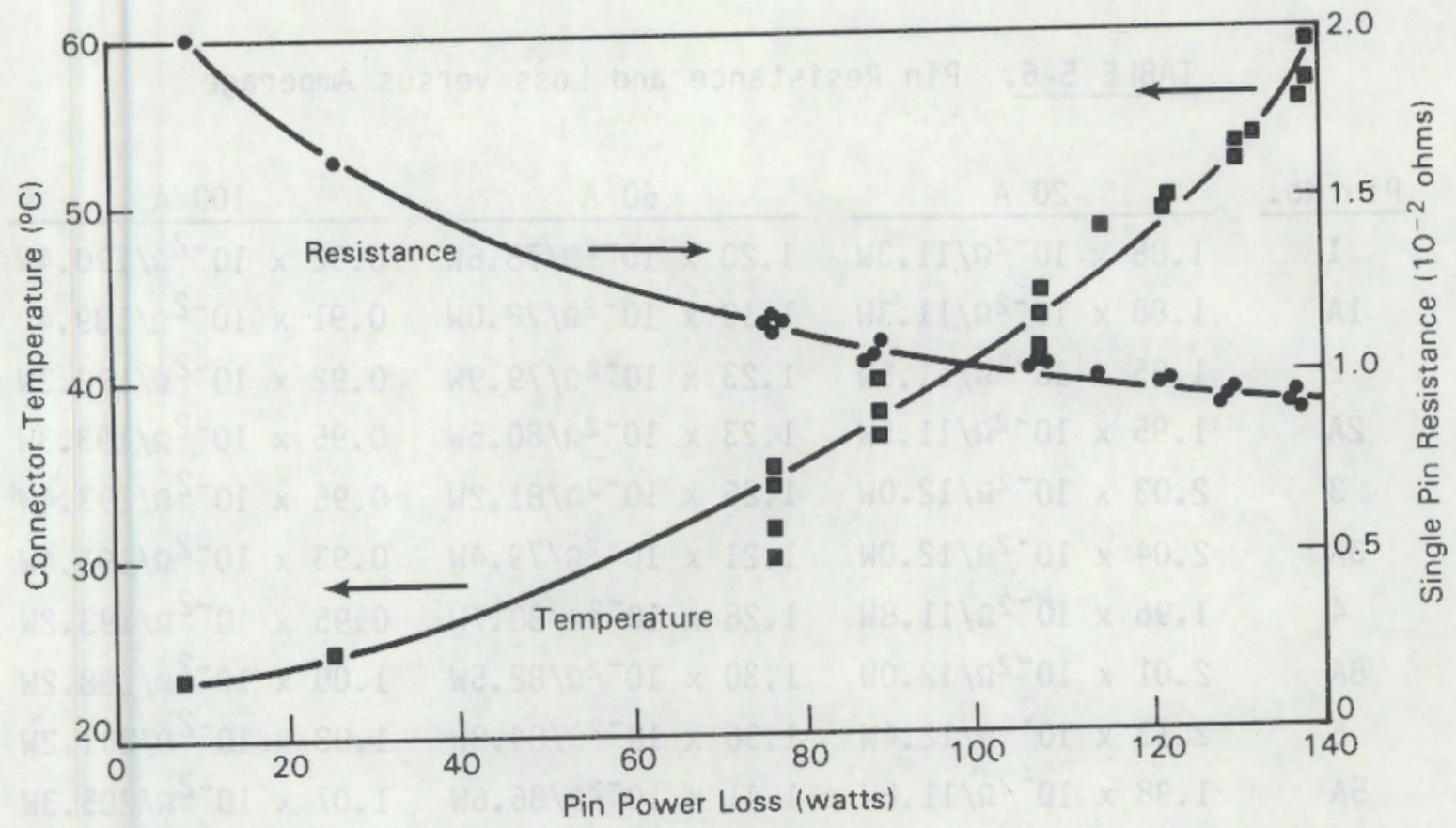

FIGURE 5-14. Pin Resistance and Connector Temperature as a Function of Pin Power Loss

temperature span of the data. A likely cause of the lower resistance at higher temperatures is as follows: a) as pin temperatures increase, the temperature of the flexible contact bands increases causing the bands to expand; b) the expansion of the band against the pin and socket surfaces would result in a lowering of pin/socket resistance as is observed. Table 5-6 summarizes further data, taken at 20,60, and $100 \mathrm{~A}$ for the remaining pins tested.

During initial testing, power to the discharge thermal mockup apparatus was routed through 16 of the 20 pins. Temperatures in the mock jumper were recorded to assess heating within the jumper conduit. The average conduit temperature, as measured in three locations, was $41^{\circ} \mathrm{C}$. In general, it appears that conduit size, rather than pin capacity within the connector body, will limit the amount of service wires that can be contained in a jumper; the Hanford connector body required modification to accommodate the $4 \mathrm{in}$. conduit, and wire installation was difficult due to the sharp $90^{\circ}$ bend of the wires within the upper connector body. Figure 5-15 is an internal view of the upper connector with wires installed. 
TABLE 5-6. Pin Resistance and Loss versus Amperage

\begin{tabular}{|c|c|c|c|}
\hline in No. & $20 \mathrm{~A}$ & $60 \mathrm{~A}$ & $100 \mathrm{~A}$ \\
\hline 1 & $1.88 \times 10^{-2} \Omega / 11.3 \mathrm{~W}$ & $1.20 \times 10^{-2} \Omega / 78.6 \mathrm{~W}$ & $0.92 \times 10^{-2} \Omega / 190.4 \mathrm{~W}$ \\
\hline $1 \mathrm{~A}$ & $1.88 \times 10^{-2} \Omega / 11.3 \mathrm{~W}$ & $1.19 \times 10^{-2} \Omega / 78.0 \mathrm{~W}$ & $0.91 \times 10^{-2} \Omega / 189.4$ \\
\hline 2 & $1.95 \times 10^{-2} \Omega / 11.5 \mathrm{~W}$ & $1.23 \times 10^{-2} \Omega / 79.9 \mathrm{~W}$ & $0.92 \times 10^{-2} \Omega / 190.3 \mathrm{~W}$ \\
\hline $2 A$ & $1.95 \times 10^{-2} \Omega / 11.5 \mathrm{~W}$ & $1.23 \times 10^{-2} \Omega / 80.5 \mathrm{~W}$ & $0.95 \times 10^{-2} \Omega / 193.3 \mathrm{~W}$ \\
\hline 3 & $2.03 \times 10^{-2} \Omega / 12.0 \mathrm{~W}$ & $1.26 \times 10^{-2} \Omega / 81.2 \mathrm{~W}$ & $0.95 \times 10^{-2} \Omega / 193.4 \mathrm{~W}$ \\
\hline $3 \mathrm{~A}$ & $2.04 \times 10^{-2} \Omega / 12.0 \mathrm{~W}$ & $1.21 \times 10^{-2} \Omega / 79.4 \mathrm{~W}$ & $0.93 \times 10^{-2} \Omega / 191.4 \mathrm{~W}$ \\
\hline 4 & $1.96 \times 10^{-2} \Omega / 11.8 \mathrm{~W}$ & $1.28 \times 10^{-2} \Omega / 80.7 \mathrm{~W}$ & $0.95 \times 10^{-2} \Omega / 193.2 \mathrm{~W}$ \\
\hline $8 \mathrm{~A}$ & $2.01 \times 10^{-2} \Omega / 12.0 \mathrm{~W}$ & $1.30 \times 10^{-2} \Omega / 82.5 \mathrm{~W}$ & $1.00 \times 10^{-2} \Omega / 198.2 \mathrm{~W}$ \\
\hline 5 & $2.13 \times 10^{-2} \Omega / 12.4 \mathrm{~W}$ & $1.36 \times 10^{-2} \Omega / 84.8 \mathrm{~W}$ & $1.03 \times 10^{-2} \Omega / 201.2 \mathrm{~W}$ \\
\hline $5 A$ & $1.98 \times 10^{-2} \Omega / 11.8 \mathrm{~W}$ & $1.41 \times 10^{-2} \Omega / 86.6 \mathrm{~W}$ & $1.07 \times 10^{-2} \Omega / 205.3 \mathrm{~W}$ \\
\hline 6 & $0.31 \times 10^{-2} \Omega / 5.3 \mathrm{~W}$ & $1.27 \times 10^{-2} \Omega / 80.9 \mathrm{~W}$ & $0.96 \times 10^{-2} \Omega / 194.2 \mathrm{~W}$ \\
\hline $6 \mathrm{~A}$ & $0.31 \times 10^{-2} \Omega / 5.3 \mathrm{~W}$ & $1.11 \times 10^{-2} \Omega / 77.3 \mathrm{~W}$ & $0.91 \times 10^{-2} \Omega / 189.2 W$ \\
\hline
\end{tabular}

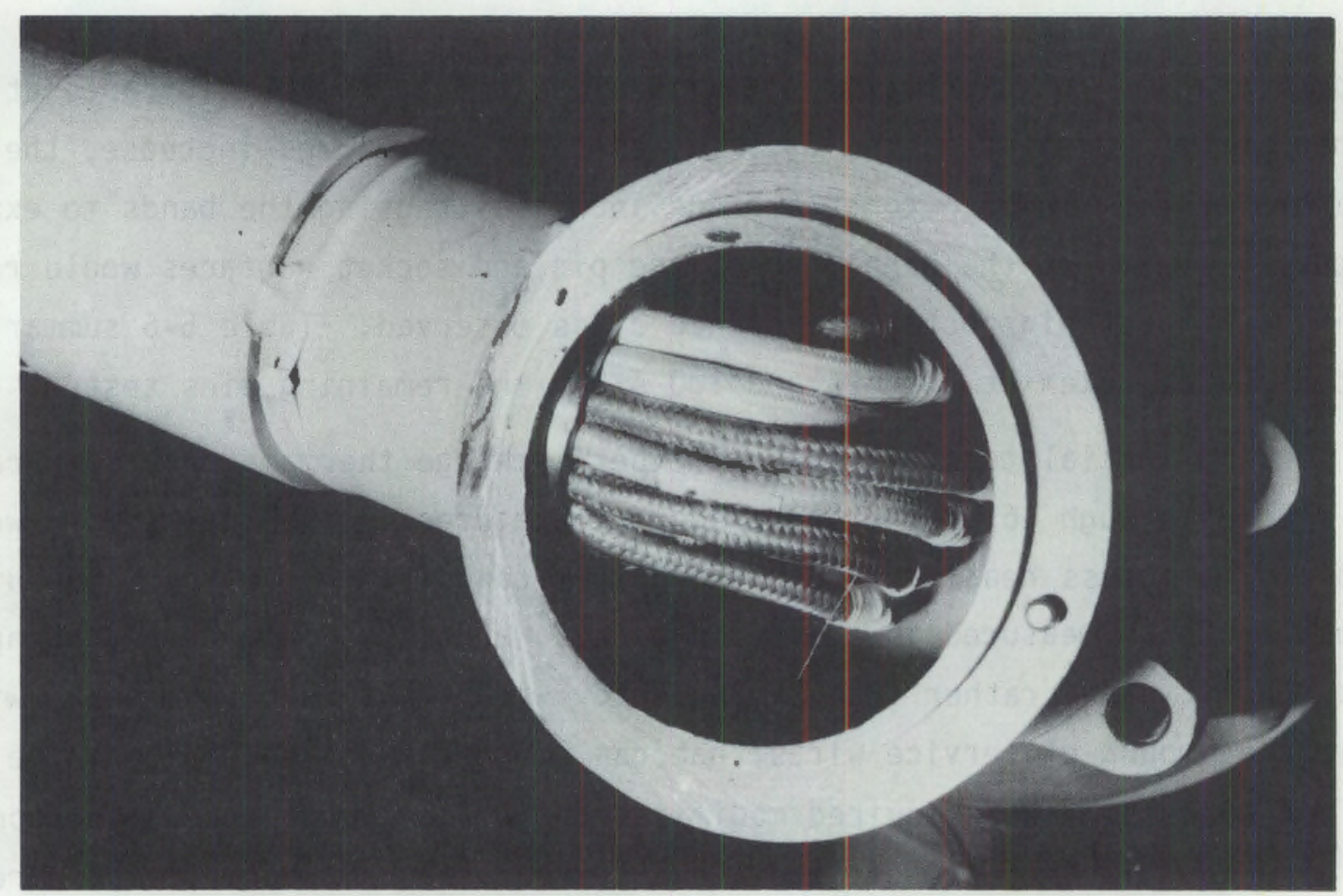

FIGURE 5-15. Internal View of Upper Connector with wires Installed 
Temperature in either the conduit or the connector was not considered high enough to require air cooling within the jumper. The connector was easily installed and functioned well even after five connection/reconnection cycles and when operated at power levels exceeding $130 \%$ of the individual pin's rated capacity.

\subsubsection{Closed Circuit Television Signal Transmittance}

Initially, a multi-pin connector containing a coaxial assembly was planned for connecting the TV camera coaxial cable. The coaxial assembly was to provide shielding within the connection, preventing radio frequency interference (RFI). However, the fitting of the fabricated coaxial pin assembly resulted in poor pin contact. The shielded wire was routed instead through a typical instrument signal pin and was visually observed to be capable of transmitting the camera signal as evidenced by an image received on a black and white monitor. No RFI was noted. The image was considered to be free of defects when compared to closed circuit monitors used in other applications. Nonshielded (noncoaxial) connectors are often used in industry with similar results. The complex coaxial pin assembly is therefore considered unnecessary.

\subsection{CONCLUSIONS}

- Multi-pin electrical and instrument jumper installation is as straightforward as the installation of other remote jumpers, although initial break-in of the connector is recommended.

- The multi-pin electrical connector is well suited to remote electrical service.

- The ampacity of power connector pins can be expected to extend to $130 \%$ or more above pin ratings without requiring jumper/connector cooling. Wiring should not be underrated however.

- The heat loss in a $20 \mathrm{pin}, 90 \mathrm{~A} / \mathrm{pin}$ connector is calculated to be 1660 W.

- The physical size of electrical wire, rather than pin number, limits the capacity of an electrical jumper. 
- Coaxial (shielded) cable signals can be passed through unshielded instrument pins without incurring radio frequency interference under normal ambient radio frequency fields. The complexity of coaxial pins, while feasible, can at least sometimes be avoided.

- A regular multi-pin (noncoaxial) connector is well suited to transmitting remote closed-circuit TV camera signals.

- Pin wear is not a potential problem.

- The multi-pin instrument connector is well suited for transmitting remote thermocouple, strain gauge, and other signals.

- The temperature offset associated with transmitting thermocouple signals through the connector pins has a mean value of $-0.237^{\circ} \mathrm{C}$.

- The mean offset value is independent of the temperature being measured, independent of the number of times the connector is disconnected/reconnected, and slightly dependent $\left( \pm 0.167^{\circ} \mathrm{C}\right.$ maximum) on variations among different pins.

\subsection{RECOMMENDATIONS}

1. It is recommended that "floating" pin assemblies, rather than the current fixed (immobile) pin assemblies, be used in the multi-pin connector to reduce the extremely tight tolerances associated with the current pin isolation plate design. The current tolerances are difficult to maintain during fabrication leading to difficult alignment of the pins during initial remote jumper installation.

2. It is recommended that a computer simulation be performed using the test data in Table 5-5 as a basis to determine temperature profiles within the fiberglass insulation materials to assess the possibility of melting during full power operation, e.g., $90 \mathrm{~A}$ on all 20 pins. Either jumper aircooling or a nonmelting isolation material such as machineable glass would solve this problem if it exists. 
3. It is recommended that a better method be developed for routing wires from within the electrical connector to the jumper. Currently, the physical size of the wire, rather than the space available for pins, limits the capacity of an electrical jumper.

4. It is recommended that the ferrules used to retain the contact bands within the electrical contact sockets be either soldered into place or replaced with another type of band containment design. This is suggested to avoid the problem of loose ferrules noted in Section 5.3.1. 



\subsection{THERMOCOUPLE REPLACEMENT SYSTEM}

Temperatures $\left(\sim 1150^{\circ} \mathrm{C}\right)$ within the melting cavity must be monitored over the life of the joule-heated ceramic melter system and, since thermocouples are relatively short lived in the melting cavity environment, a method of remotely installing and removing thermocouples has been developed and tested. The thermocouples replacement system provides a method of allowing individual thermocouples to be manually installed into a thermowell located in the melter or other process vessel.

The thermocouple replacement system consists of a thermocouple jumper, a wal1 plug and a remotely removable melter thermowell in the configuration shown in Figure 6-1. Thermocouples are manually installed from the operating gallery, through the thermcouple guide tube of the wall plug, through the thermocouple jumper located in-cell, and into the thermowell located in the melting cavity. Since this method provides a continuous guide path from operating gallery to the melter, two sets of contact points between the thermocouple leads and the recording device are eliminated. The jumper and thermowell are remotely replaceable. After the jumper becomes full of original and replacement thermocouples, the entire jumper containing the thermocouples, is removed and replaced by remote means.

The feasibility was demonstrated for remotely installing, maintaining, and removing a thermocouple jumper assembly, and for remote handling aspects of the thermocouple jumper.

\subsection{TEST EQUIPMENT}

A full-scale prototype thermocouple jumper, wall flange and thermowell were built and tested. The thermocouple jumper consists of a $12-\mathrm{ft}-\mathrm{long}$ section of 1-in., Sch.80, carbon-steel pipe, with two different bends, representing a typical jumper configuration shown in Figure 6-2. The end of the jumper that interfaces with the mockup cell wall has an enlarged section fabricated from a 4-in.-piece of 1-1/2-in. Sch.40 pipe, and a 1-1/2-in. x 1in. Sch.40 concentric reducer. This configuration allows the thermocouples to be easily inserted into the jumper when exiting from the through-the-wall guide tube portion, since the thermocouple wire is traveling from a smaller to a larger diameter guide tube. 


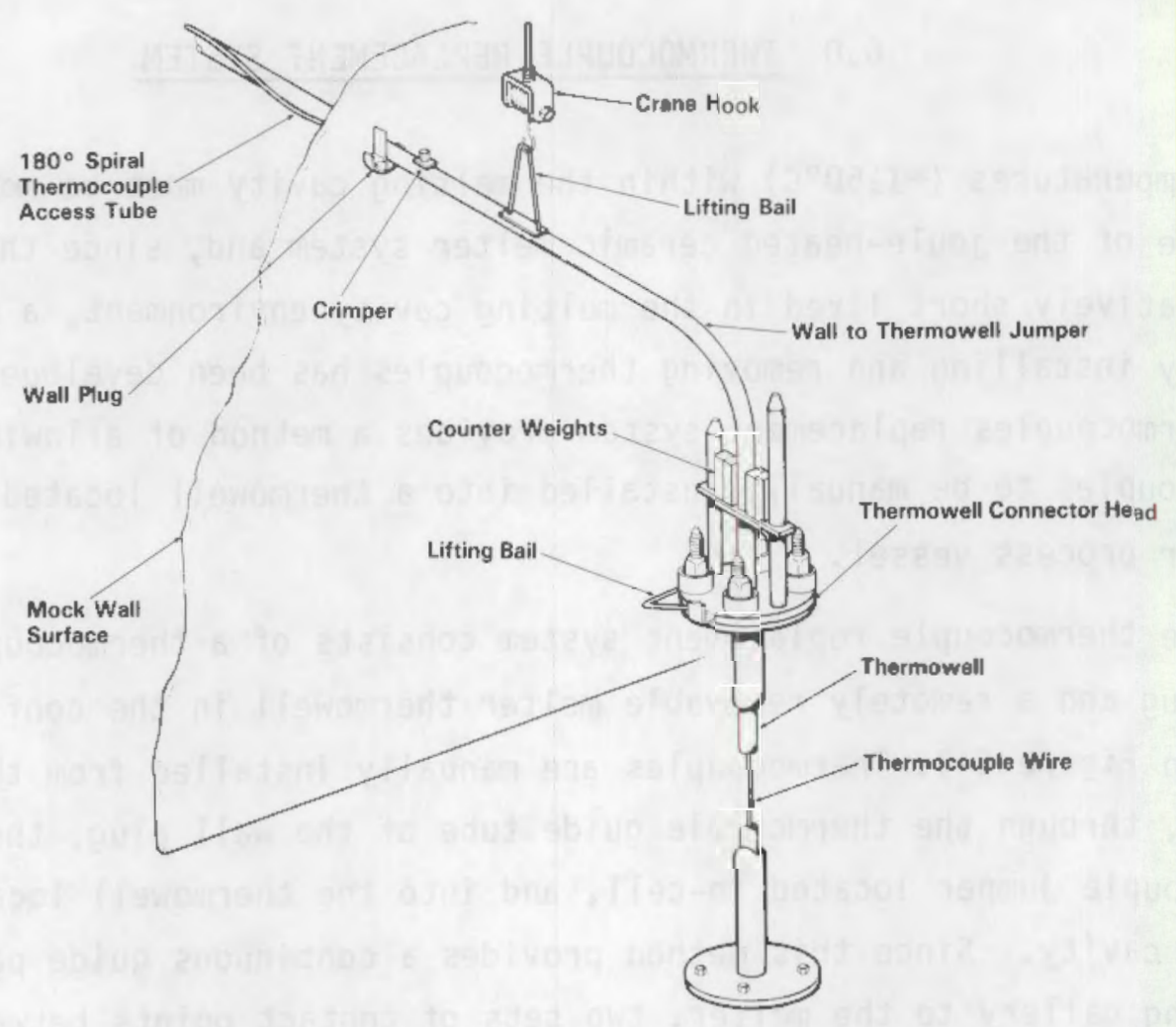

FIGURE 6-1. Thermocouple Jumper Test Assembly

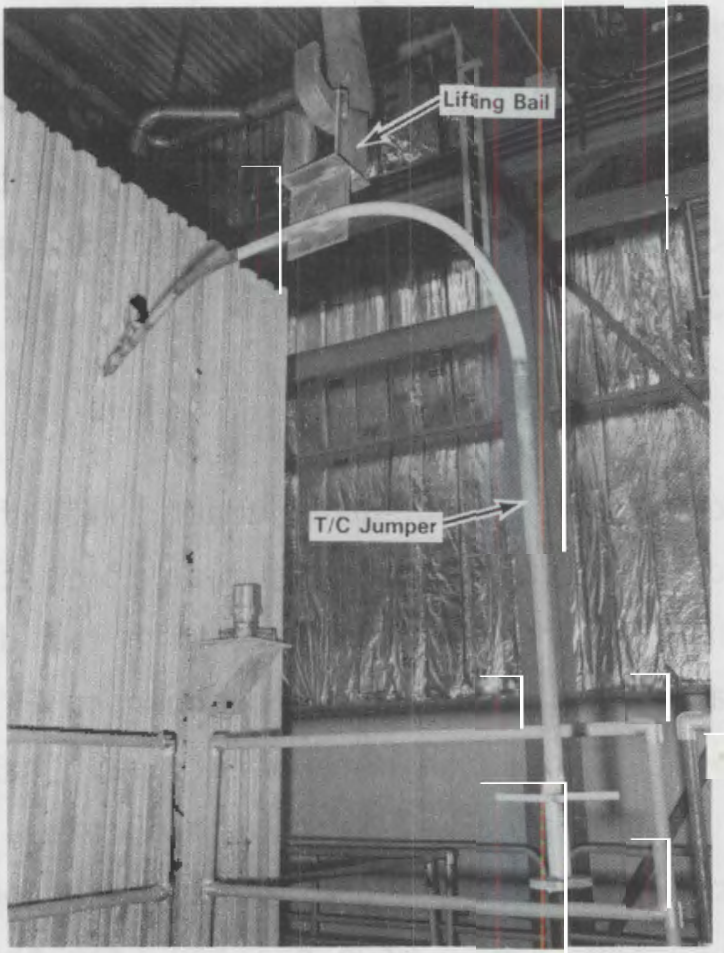

FIGURE 6-2. Thermocouple Jumper Assembly 
Once into the thermocouple jumper, the concentric reducer provides a smooth transition for the thermocouple wire to continue traveling in a 1-in. pipe system.

The end interfacing with the mockup melter has a flange that rests against a corresponding flange of the thermowell assembly. A rectangular guide plate is located $\sim 6$ in. above the flange, which interfaces with the two guide pins (Figure 6-3a). These pins guide the thermocouple jumper in the proper orientation as the unit is lowered into place on the thermowell flange. The thermocouple jumper has a crimp-nut device located 12 in. from the wall end of the jumper (Figure 6-3b). The crimp-nut is activated using the PUREX electric impact wrench with 2-in. socket. The crimp-nut mechanism holds the sheathed thermocouple that passes through the jumper. The crimp-nut mechanism holds the thermocouple in place in the jumper to allow the $T / C$ s and jumper to be removed as a unit into the cell.

The thermowell section (Figure 6-4) consists of a 3-ft length of 1-in. Sch.40 pipe to which an electrically insulated flange has been attached to one end. The flange is designed for remote handling using standard remote guide pins, studs, and nuts. Note that there is no mechanical connection between the thermocouple jumper and the thermowell flange. The guide pins serve only for alignment of the jumper assembly with the thermowell and the thermowell with the nozzle flange. The thermocouples, when inserted through the jumper, are guided by a chamfered section on the top side of the thermowell flange on into the body of the thermowell.

The through-the-wall portion of the thermocouple jumper assembly, shown in Figures $6-5 a$, is the portion of the through-the-wa11 section that protrudes from the inside surface of the mocked-up hot-cell wall. This guides the wall end of the thermocouple jumper into alignment with the hole in the base of the guide unit. The hole in the base of the guide unit is the exit point of the spiral. The through-the-wall thermocouple guide tube is shown in Figure 6-5b. The spiral thermocouple guide tube, which consists of 3/4-in. Sch.40 pipe, with a $180^{\circ}$ spiral wind in $9-\mathrm{ft}$ of travel, is supported by a corresponding section of 4 -in. Sch.40 pipe. The entire through-the-wall assembly is supported by brackets from an overhead beam (Figure 6-5c). 

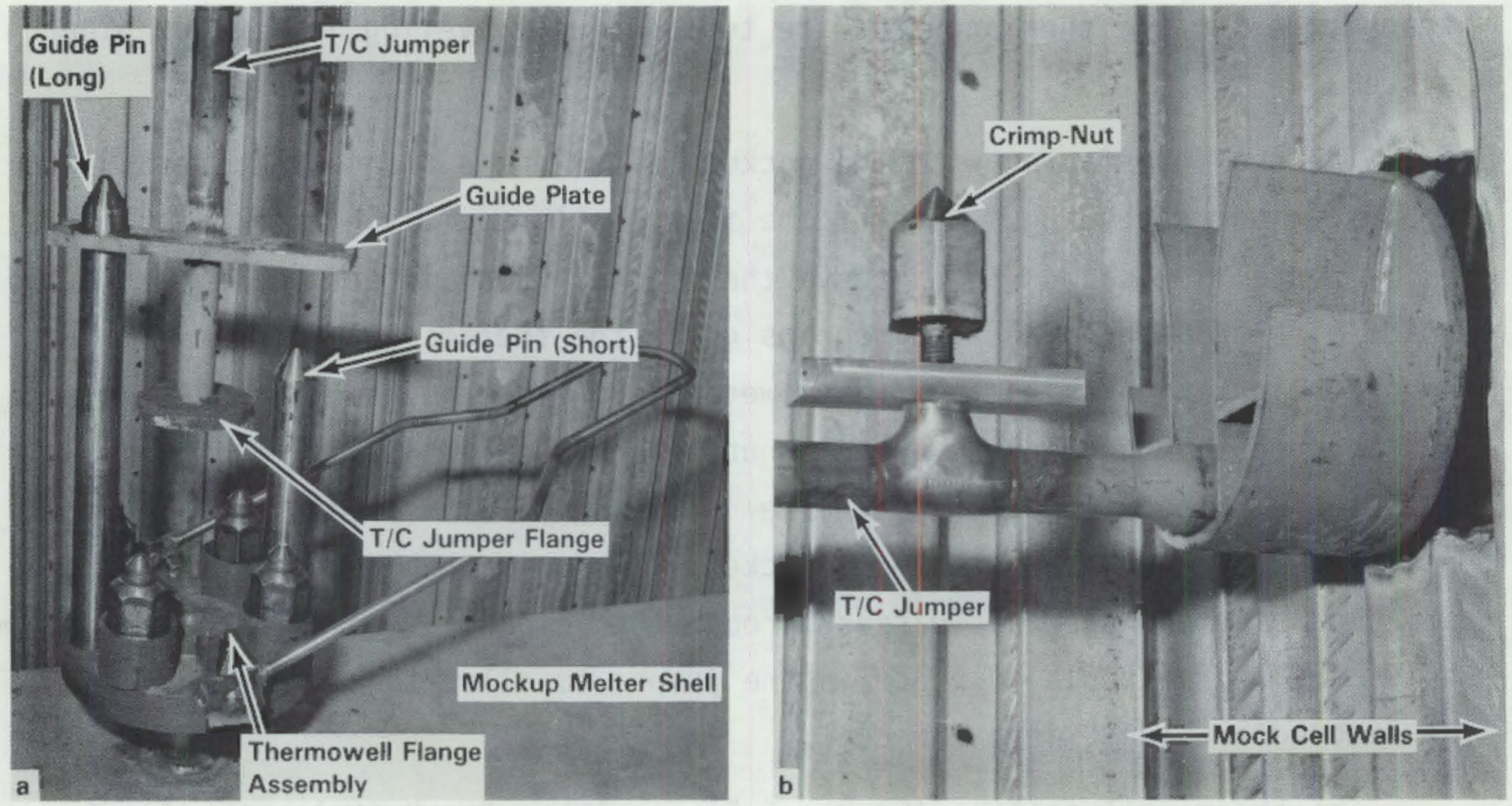

FIGURE 6-3. Thermocouple Jumper

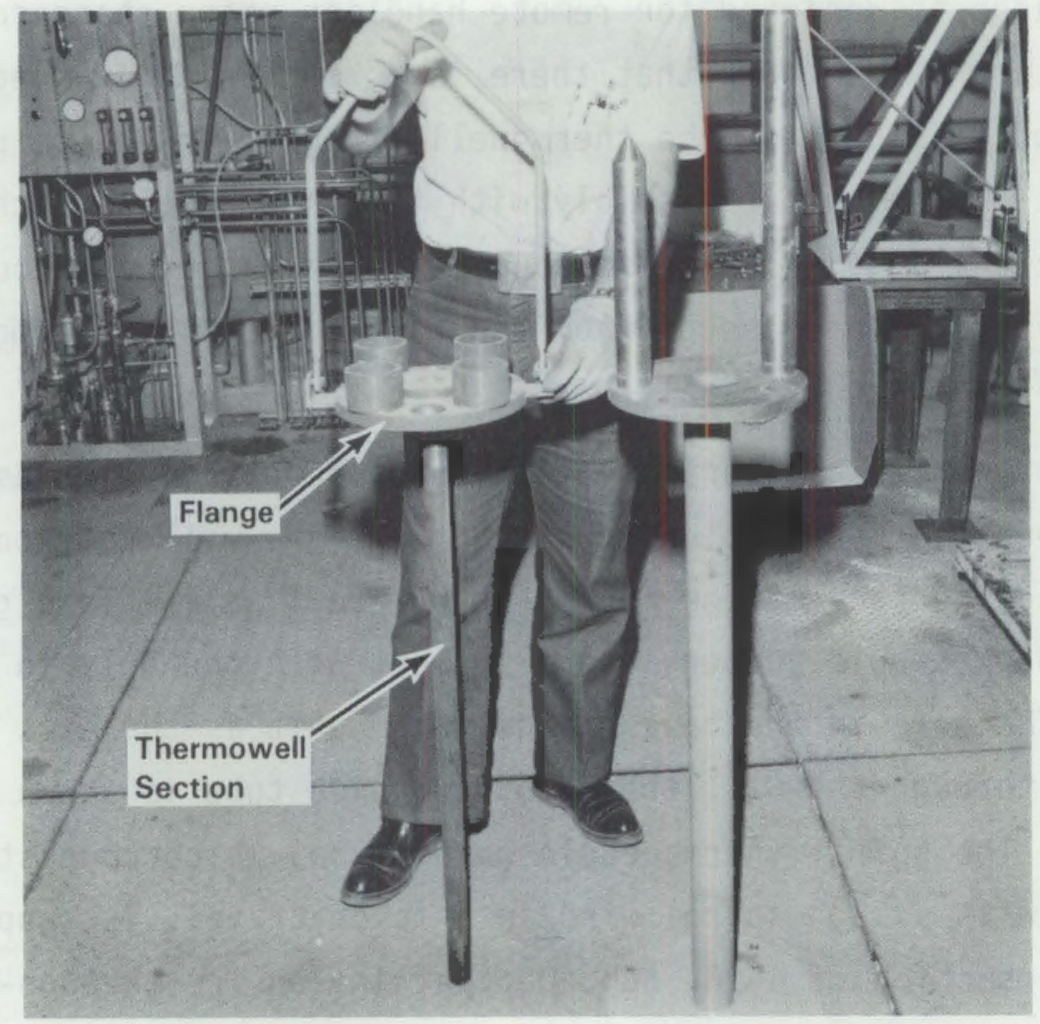

FIGURE 6-4. Thermowell section 

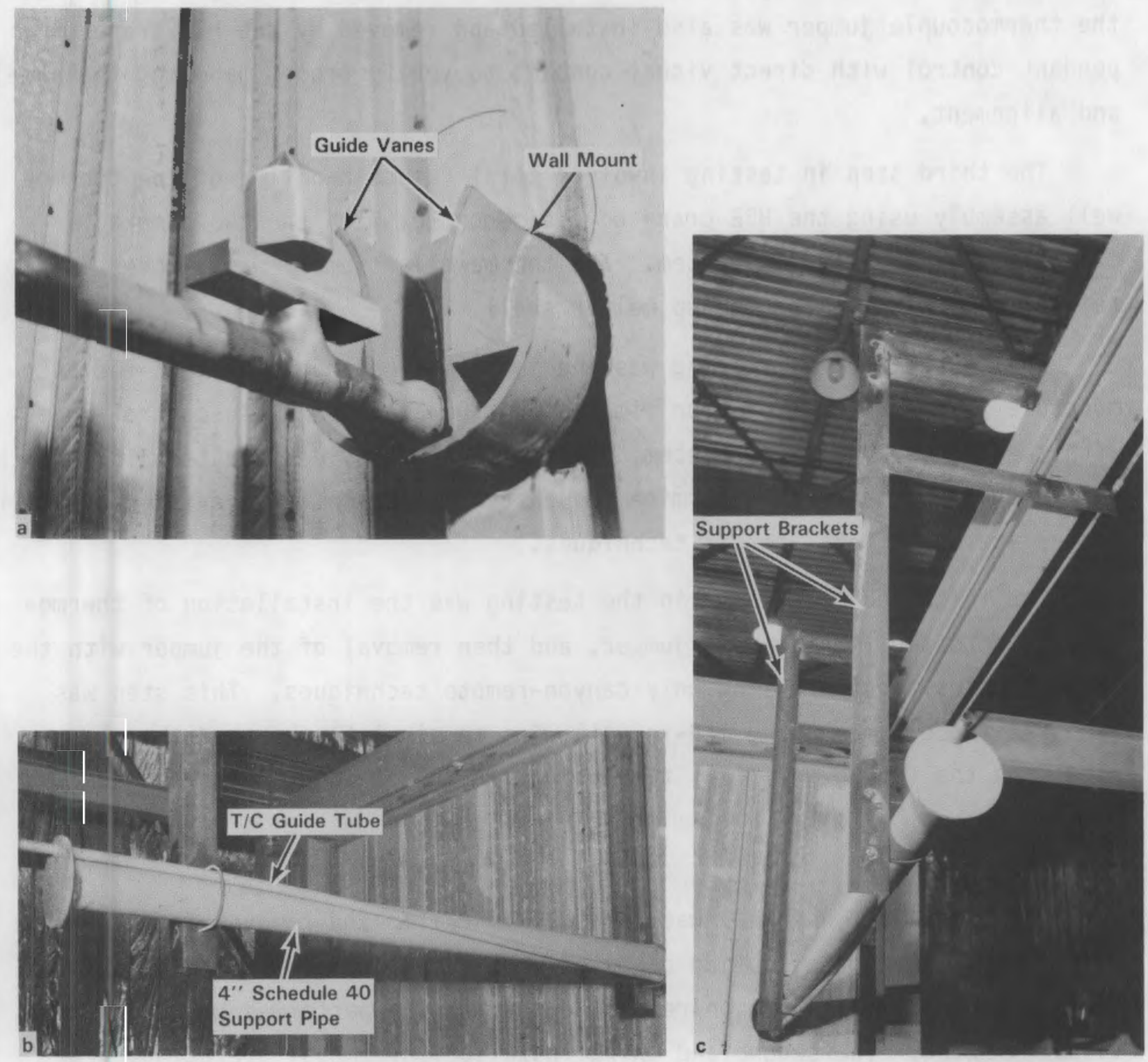

FIGURE 6-5. Through-The-Wall Thermocouple Jumper Assembly 


\subsection{TEST APPROACH}

Initially, the thermowell and the thermocouple jumper were checked manually for proper fit and correct installation, and were found to fit correctly as designed. The second step in testing consisted of installation and removal of the thermowell unit using the HBE crane on pendant control, with direct visual contact of the unit. The four free (remote) nuts were tightened and loosened on the thermowell flange using the PUREX electric impact wrench to verify proper fit and alignment of this unit. During this stage of testing, the thermocouple jumper was also installed and removed by the HBE crane on pendant control with direct visual contact to verify proper handling (balance) and alignment.

The third step in testing involved total remote handling of the thermowell assembly using the HBE crane on radio-control with the two-camera, closed-circuit TV viewing system. The thermowell assembly was removed and reinstalled twice on the mockup melter shell.

The fourth step in testing was the installation and removal of the thermocouple jumper a total of four times using the crane in radio-control mode with the remote TV viewing system. This approach provided the technician with sufficient experience to determine the best approach in maneuvering the jumper into place using total remote techniques.

The fifth and final step in the testing was the installation of thermocouples into the thermocouple jumper, and then removal of the jumper with the thermocouples together using only canyon-remote techniques. This step was repeated three times using 1/8-in.-dia wire to simulate sheathed thermocouples, and the fourth and final time using 1/8-in. Ss sheathed thermocouples.

\subsection{RESULTS}

The thermowell assembly was remotely installed and removed from the mock melter shell three times using crane-only (canyon-remote) techniques. The first thermowell installation/removal operation was performed using direct visual viewing. The second and third installation/removal operations were performed totally remote, i.e., with closed-circuit TV viewing. No difficulties were encountered during the tests. 
The impact wrench, positioned on one of four of the remote free nuts on the thermowell assembly, is shown in Figure 6-6a. In Figure 6-6b, the impact wrench has been removed from the crane, and the hook is engaging the lifting bail on the thermowell assembly. The thermowell assembly is being removed from the mockup melter shell in Figure 6-6c. The installation of the thermowell assembly is the reverse of the removal sequence. The long and short guide pins, as shown in Figure 6-6, provide alignment of the thermowell flange onto the mockup melter. Different heights in the guide pins allows engagement of only one pin first, then the second, as the unit is lowered down into place, thus providing maximum ease of installation.

The thermocouple jumper assembly was remotely installed and removed from the mock cell wall and melter assembly five times, using crane-only techniques. The first installation/removal operation was done with direct visual viewing with no difficulty. The remaining four sequences were performed totally remote, i.e., with closed-circuit TV viewing. The thermocouple jumper installation is shown in Figure 6-7.

Figure 6-7a shows the thermocouple jumper suspended by its remote handling bail from the HBE crane hook. Figures $6-7 \mathrm{~b}$ and $6-7 \mathrm{c}$ show the melter end and wall end of the thermocouple jumper, respectively, being lined up prior to final placement. The thermocouple jumper lowered into place over the thermowell guide pins and the wall guide is shown in Figure $6-7 d$.

A total of eight thermocouples were installed for this particular test. A maximum of ten 1/8-in.-dia simulated sheathed thermocouples using new aluminum wire were inserted during one of the tests.

In Figure 6-8, the impact wrench has been lowered onto the thermocouple jumper crimp nut to tighten the thermocouples prior to removal of the jumper. Figure 6-9 shows the melter end and wall end of the thermocouple jumper as it was being removed. The thermocouples held in place by the crimp nut allowed removal of the jumper by the crane hook.

Results of the tests confirm that this thermocouple installation system is a viable method of installing thermocouples in the melter without the need for any in-cell instrument connections. 

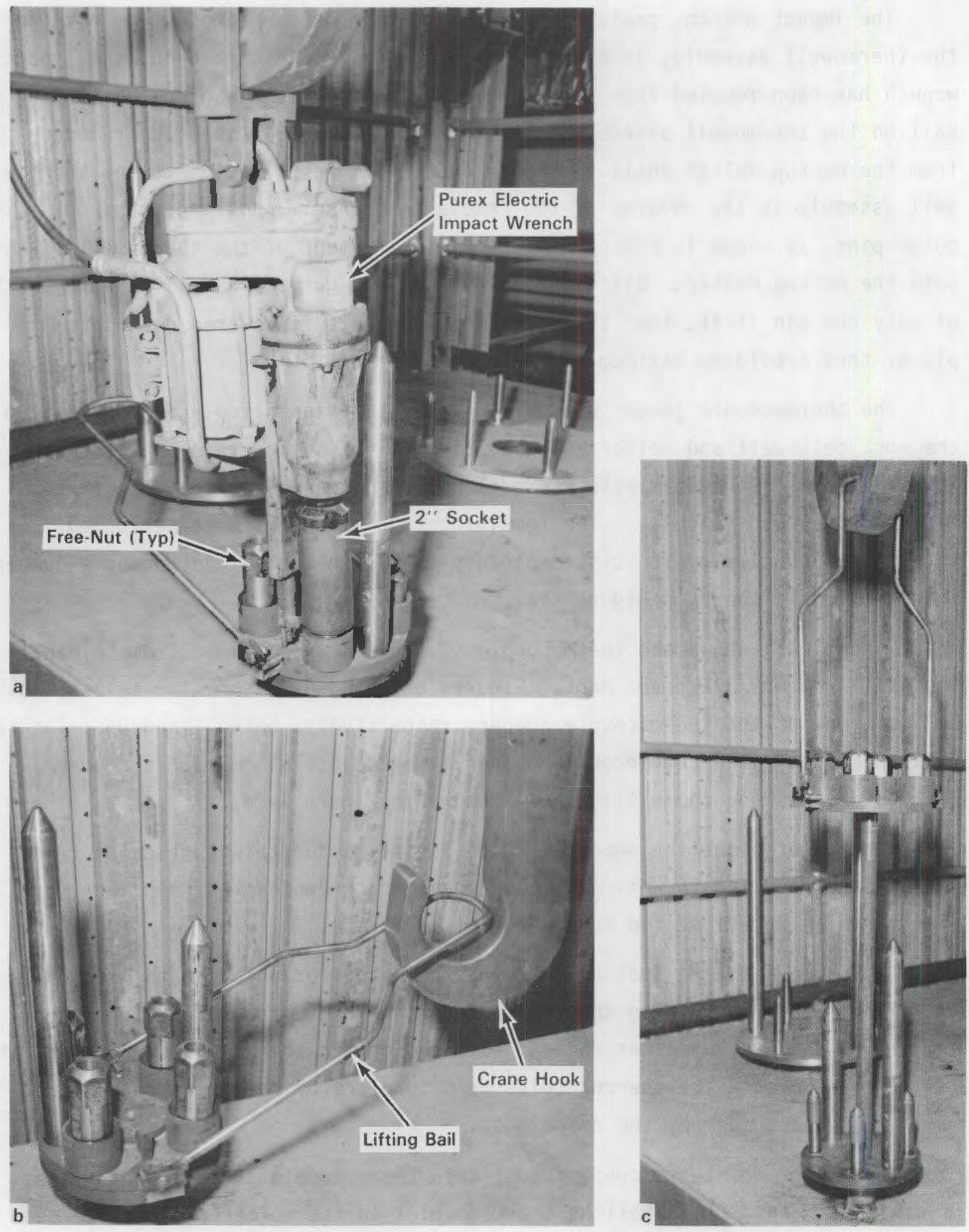

FIGURE 6-6. Thermowell Removal 

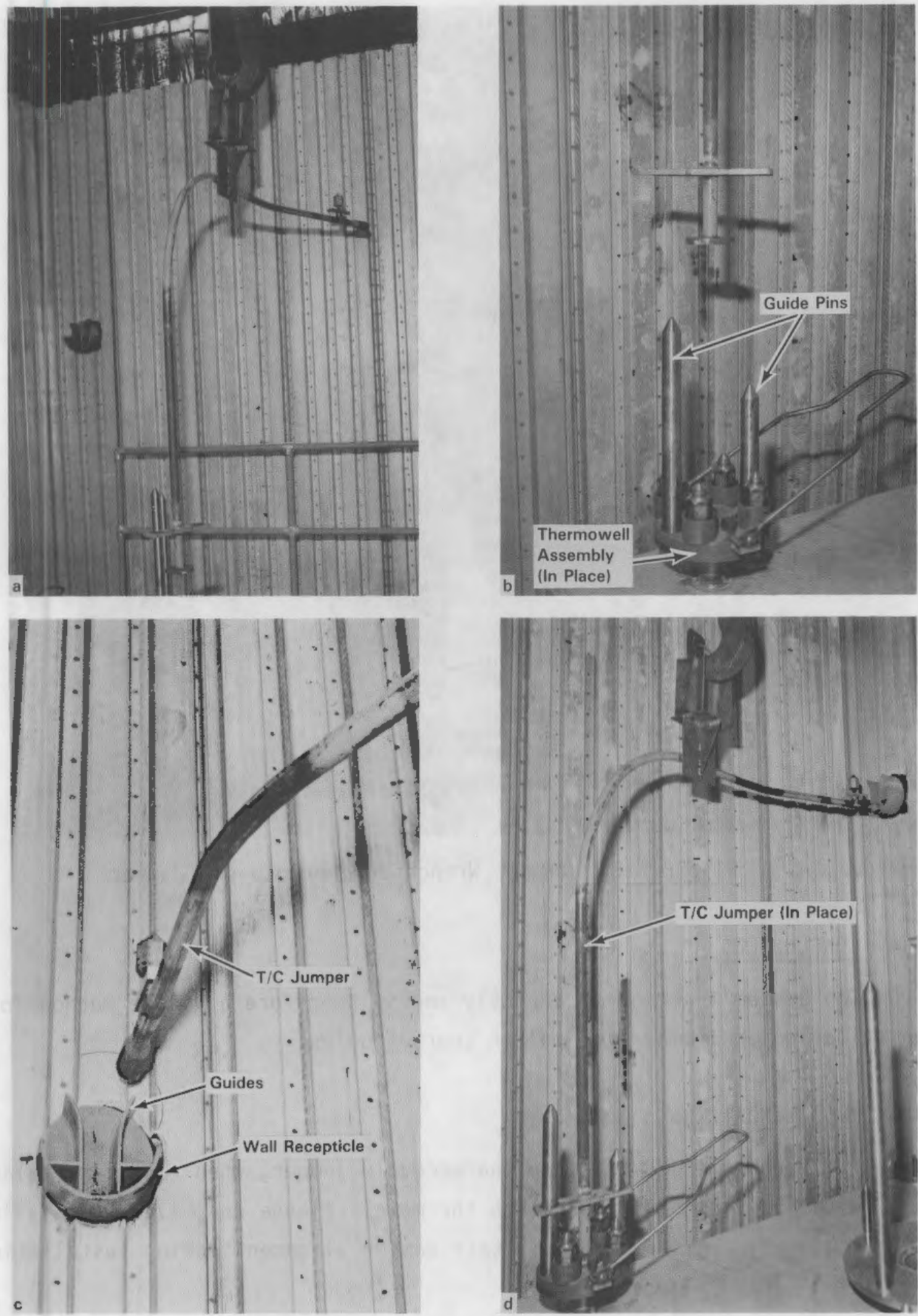

FIGURE 6-7. Thermocouple Jumper Installation 


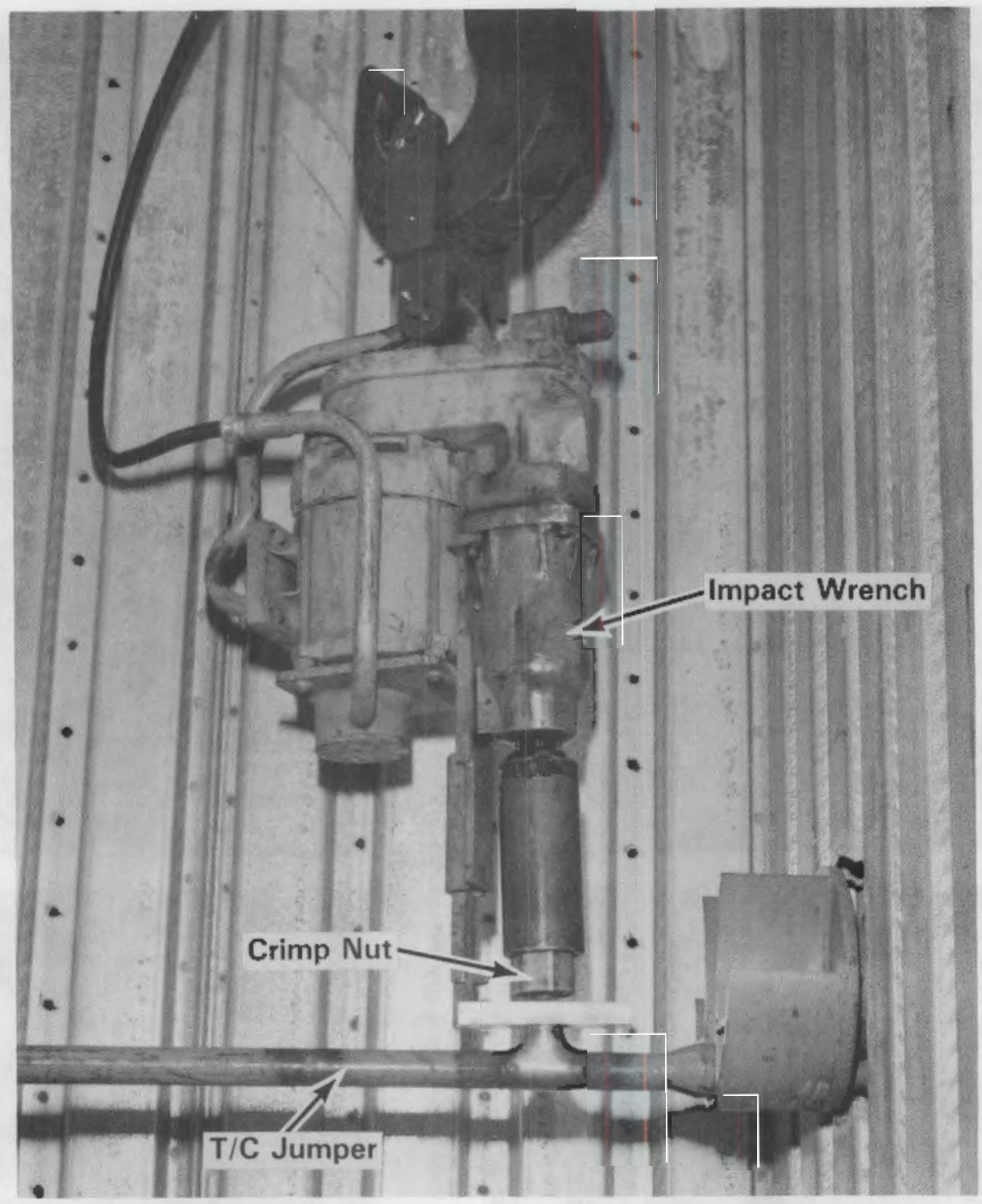

FIGURE 6-8. Impact Wrench on Thermocouple Jumper

\subsection{CONCLUSIONS}

The system functioned correctly and is therefore a viable method for installation and removal of melter thermocouples.

\subsection{RECOMMENDATIONS}

1. It is recommended that the thermocouple jumper, when empty, be balanced with a slight bias toward the thermowell flange end, i.e., hang slightly downward. This would facilitate easier alignment during installation. 


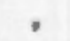

,

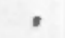

;

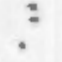




\subsection{IN-MELTER VIEWING SYSTEM}

A melter viewing system designed for radioactive service provides the operator with a view of the molten glass in the cavity of a melter. For good process control of the melter, the operator must be able to observe abnormal conditions such as foaming or excessive crusting and take corrective action. In this operation, the system must operate not only under intense radiation but also in intense heat from the molten glass. The system must be remotely replaceable by an overhead crane and an impact wrench.

The melter viewing system has a periscope section that $f i t s$ into a port in the top of the melter and projects an image into an industrial TV camera mounted on the outside of the melter. The TV signal is transmitted through a modified Hanford electrical connector and conduit to a control room outside the radiation zone. The lenses in the periscope are protected by a metal tube sealed by a metal cap with a 0.067-in.-dia aperture. The field of vision is unrestricted because the aperture is located at the focal point of the lens. The aperture is kept clear of glass spatters ejected from the surface of the melt by a continuous flow of air through the aperture. Condensation of constituents in the melter off gas on the relatively cool viewing end of the periscope will gradually accumulate an encrustation that restricts the view of the glass melt. A steam sweep of the aperture area to remove the solids formed by condensation is provided by a small line on the tip of the periscope.

The lenses for the in-melter viewing system for radioactive service would consist of a quartz wide angle lens and cerium stabilized optical glass for other lenses. Both quartz and cerium-stabilized glass are resistant to radiation damage. Quartz, which is particularly resistant to high temperatures (up to $\sim 950^{\circ} \mathrm{C}$ ), is the final lens in the periscope.

Since the camera operates in the visible and near infrared (IR) range, a light source is required in order to produce an image on a TV monitor. The light source within the melting cavity is the surface of the molten glass itself. As this surface becomes covered with crust, consisting of feed materials in various stages of melting, the light source for the camera becomes obscured. The extent of crust, or cold cap, on the molten surface can 
therefore be judged using the camera simply by noting the dark spots on the TV monitor. Should the entire surface of the melt become covered with cold cap, an unwanted situation, the image of the melting cavity would become completely dark because of the total obscuration of the molten glass by the cold cap. The TV camera, therefore, provides an unambiguous indication of the extent of the cold cap since the molten surface serves as the sole light source.

In previous testing, the melter viewing system has been evaluated for its ability to preclude spatters on the lens for ruggedness and remotability. Early tests in an operating pilot-scale melter, demonstrated a need for improved heat-resistant lens and a steam purge to remove condensed solids.

The melter viewing system withstood the shock of swinging into objects as the periscope section was lowered into a melter port. The vibration of the operating impact wrench disrupted picture transmission during bolting to the melter flange, but the picture reappeared on the TV monitor when the bolts were tight and the impact wrench was removed.

\subsection{TEST EQUIPMENT}

The melter viewing system combines a closed circuit TV camera and a periscope assembly to view the melt surface. The periscope, which contains a portion of the optics, isolates the camera from the intense heat of the melter cavity. The major components of the melter viewing system are a camera, compound lens, infrared filter, adjustable iris, steam purge, cooling air, and aperture air (Figure 7-1).

A black and white high-resolution camera is used to transmit the image received to the monitor. The image tube in the camera has a silcon diode target and is very sensitive to radiation in the near IR region.

Two sets of lenses are used in the melter viewing system. The compound lens properly focuses the image before it is received by the camera. The camera itself does not have any lenses. The wide angle lens located at the end of the periscope is used to view the melt surface through the $67 \mathrm{~mL}$ ( $0.067 \mathrm{in.)}$ hole on the end cap. The hole is small to prevent material from entering the hole and depositing on the lens. The wide angle lens is set very 


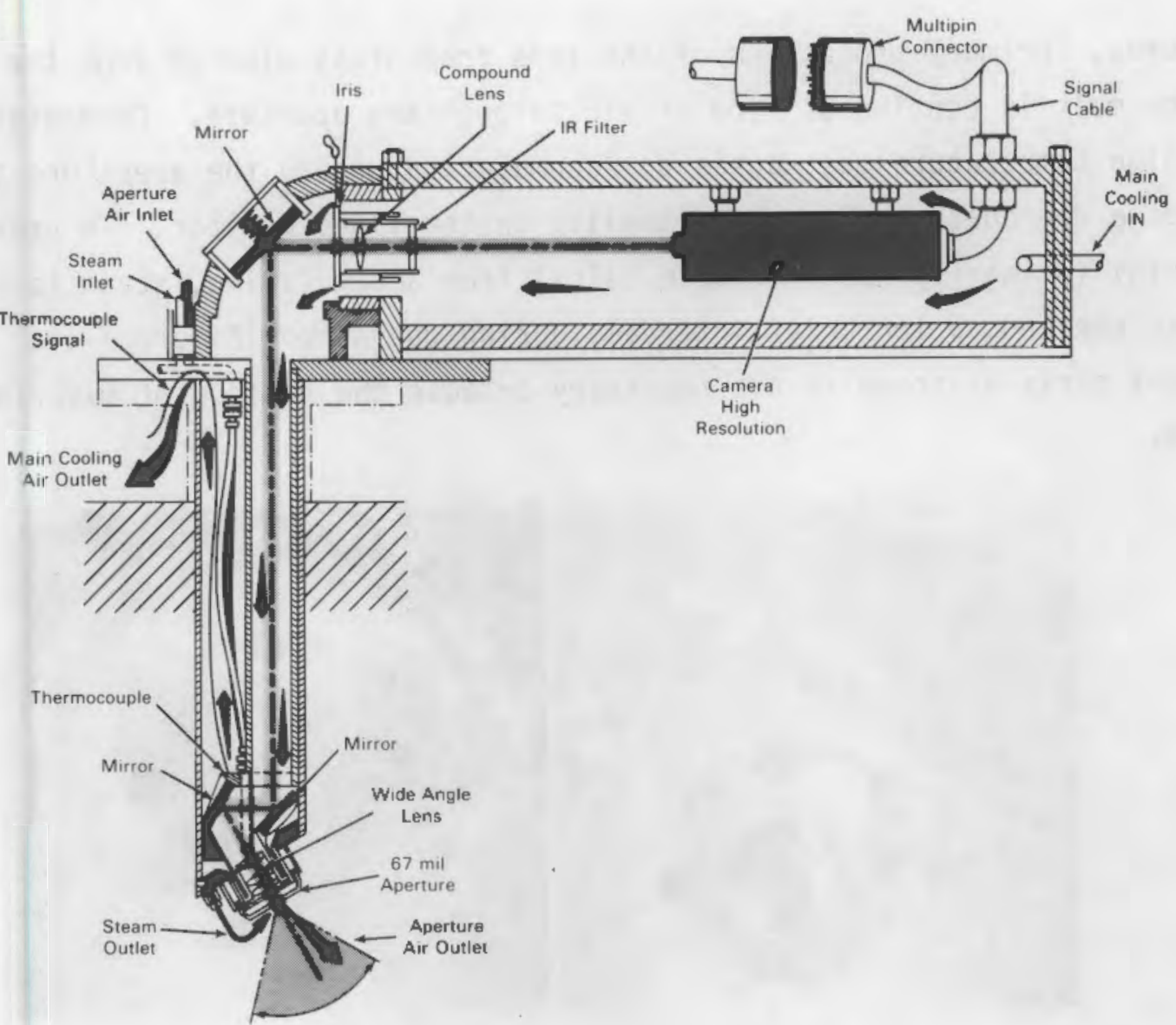

FIGURE 7-1. Melter Viewing System Components and Cooling Air Flow

close to the inside of the end cap where the hole is located. It works like a peephole; the closer the viewer is to the hole, the wider the area viewed on the other side.

Because the image tube in the video camera is extremely sensitive to radiation in the near IR region, an IR filter (or hot mirror) is used to reduce the intensity of radiation of these wavelengths. The IR filter prevents the image tube of the camera from being overloaded.

The iris reduces the intensity of visible light received by the image tube. The iris can be adjusted by means of a wire connected to the aperture adjustment (Figure 7-2). The iris in a radioactive melter viewing system probably would be adjusted for optimum picture before installation to eliminate the complication of a remote adjustment device.

The wide-angle lens at the end of the periscope is protected from glass spatters ejected and condensation of off-gas particles by two different design 
features. Primary protection of the lens from glass ejected from the surface of the melt is continuous flow of air through the aperture. Condensation of the high temperature gas causes an accumulation around the aperature that causes a degradation of picture quality on the video monitor. To prevent this material (primarily water-soluble salts) from accumulating, steam is sprayed across the endcap for brief intervals during operation (Figure 7-3). A continuous spray of steam is not necessary because the buildup of material is not rapid.
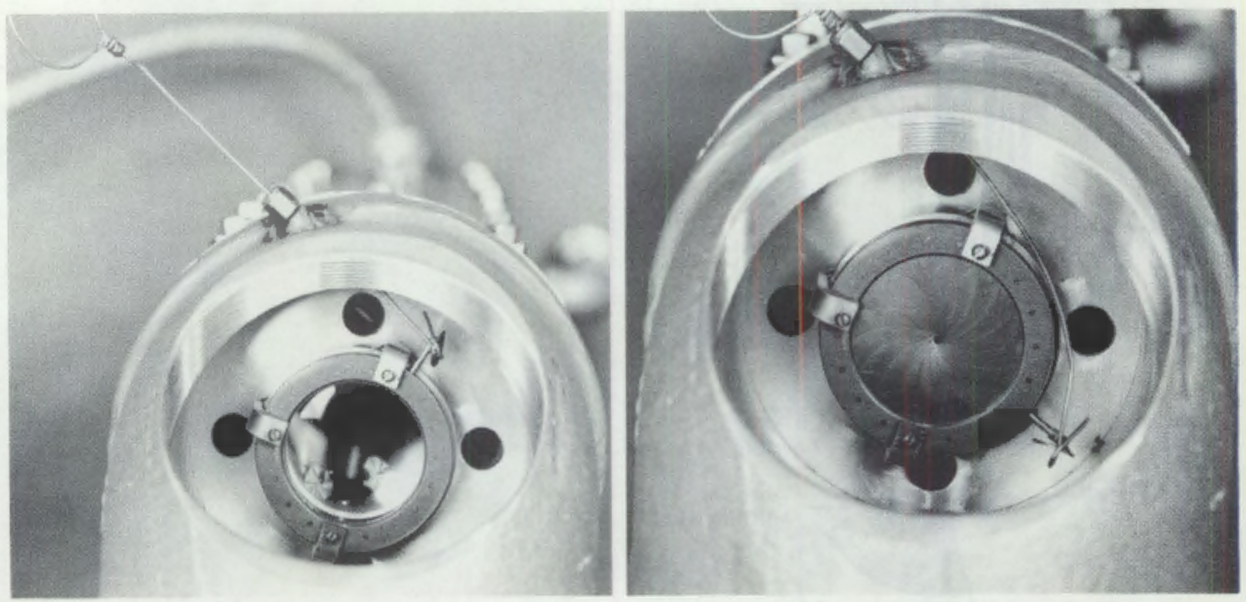

FIGURE 7-2. Adjustable Iris Showing Open and Closed Positions

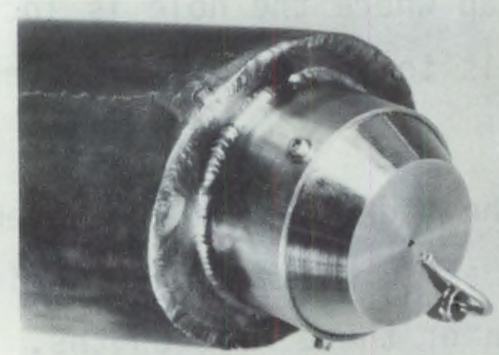

FIGURE 7-3. End Cap of Periscope Before Installation

Main cooling air is passed through the body of the melter viewing system to maintain the temperature of the electronics and optics at an acceptable level. This air enters behind the camera mounting and cools the camera first because the electronics of the camera are more sensitive to temperature than 
the optics. After flowing past the IR filter, compound lens, and iris, the air then flows down the image pathway to the wide angle lens. The wide angle lens is exposed to a thermally hot environment inside the cavity of the melter. Cooling of the wide angle lens is critical to keep the lens from cracking. During the idle mode, the region near the wide angle lens can reach temperatures exceeding $215^{\circ} \mathrm{C}$; cooling air to the lens is required at a flow rate of $16 \mathrm{scfm}$. After cooling the wide angle lens, the air flows up another passage in the periscope and exits to the cell.

The aperture air provides cooling to the last lens of the wide angle lens assembly. This cooling is necessary because the main cooling air does not flow past the last lens. The aperture air also prevents spattered material from entering the view hole and depositing on the wide angle lens as it exits through the view hole in the end cap into the melter cavity. It also prevents spattered material from bridging across the view hole. The flow of air through this hole is $\sim 1.7$ scfm.

\subsection{TEST APPROACH}

A long-term operation-to-failure test of the melter viewing system began with the installation of melter a viewing system in an operating melter. This test was to demonstrate the ruggedness of the melter viewing system that, by general appearance, would seem to be failure-prone, by installing it in an operating melter and regularly checking its operations.

Monitoring performed on the melter viewing system depended on the melter operating mode. When the melter was idling, the power to the TV camera and the TV screen was normally off, but switched on daily, and the picture clarity was noted. An idling melter requires little attention, thus a daily or oncea-shift check of the system to see if melter viewing system is operational would not deprive the operators of needed information. . During glass production, the melter and melter viewing operates continuously.

The melter viewing system has been operated continuously during one melter test. Data on camera temperature cooling air flow and air flow through the aperture was noted. 


\subsection{RESULTS}

\subsubsection{Operability}

The melter viewing system was installed in an operational melter and remained in that melter for $1155 \mathrm{~h}$ before being removed. The picture quality was good. At the time the melter viewing system was removed, dark and light horizontal bands were observed on the TV screen just as they were at the time the melter viewing system was installed. Replacement of the power cable is expected to prevent their reoccurrence.

Data on camera temperature, camera coolant air, and air flow through the aperture were measured at regular intervals. There was no effort to control camera temperature by adjusting the coolant air flow or to increase the aperture air flow rate above rates identified as adequate in previous experiments.

The melter viewing system never failed to produce a sharp, clear picture of the melter cavity and molten glass throughout the test period. After installation, the melter was operated in a idling mode for 17 days when a simulated Hanford waste was fed to the melter. The picture was sharpened by closing the iris slightly.

After about $20 \mathrm{~h}$ of processing simulated Hanford waste, a fuzziness around the edge of the picture expanded, completely obscuring the view. A short $15-\mathrm{sec}$ steam blast across the aperture cleared the obstruction and the view returned to normal. The picture remained clear for the remainder of the melter test which was terminated after $51 \mathrm{~h}$. Some solids buildup could be observed on the end cap of the periscope, which failed to obscure the view of the melter cavity. During the run, the picture darkened as result of the cold cap of undissolved material spreading across the molten surface. Cracks in this crust were clearly visible.

Daily checks of the melter viewing system, 4 days after the melter test completion, disclosed a slight fuzziness on the edge of the picture, which continued to grow steadily, obscuring more of the view. The aperture was cleaned by $10-\mathrm{sec}$ steam blasts the next day, and the picture returned to normal. The steam blasts caused a momentary increase in melter pressure. A fuzzy-edged picture reappeared six days later, which expanded to include most 
of the viewing screen before it was removed by steam cleaning 3 days later. This was the last steam cleaning in the $1155 \mathrm{~h}$ of installation in a melter before it was pulled to allow revamping the air piping to the melter viewing system. Figure 7-4 shows the incrustation observed on the end cap following removal of the melter viewing system from the melter.
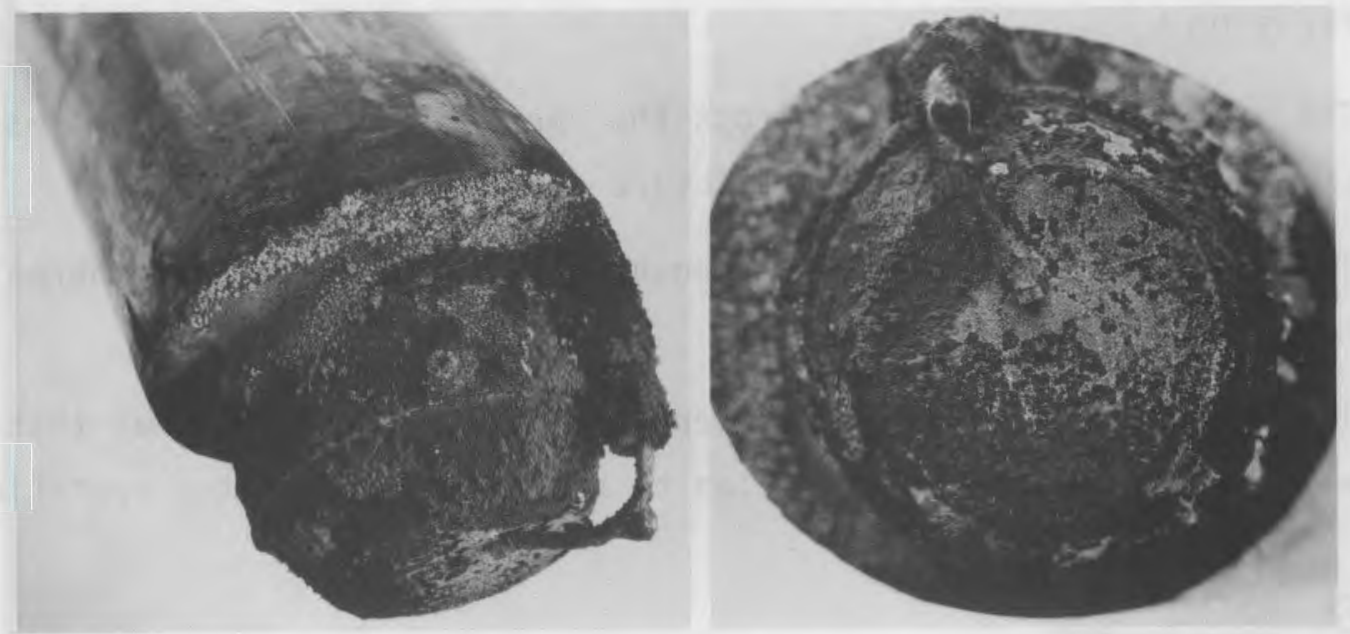

\section{FIGURE 7-4. Encrustation of Condensed 0ff-gas Chemical on Cooled Tip of Periscope}

An enhancement of the picture was realized when a color synthesizer was plugged into the TV monitor. Various colors can be assigned to segments of the TV signal, which make discrimination of subtle changes easier in the state of the glass and the crust. Convection currents in the molten glass were visible.

\subsubsection{Camera Temperature}

The air flow to the camera that controls camera cooling was fixed at $18 \mathrm{scfm}$, a rate found to be adequate in previous tests. The temperature, fluctuated, however, as conditions varied in the melter, rising to a high of $130^{\circ} \mathrm{C}$ after the melter viewing system was installed, and dropping to a low temperature of $61^{\circ} \mathrm{C}$ during the Hanford waste vitrification test. Approximately one month after the melter test, just prior to removal of the melter viewing system for piping changes, the camera temperature was at $116^{\circ} \mathrm{C}$, and 
there was no indication that the temperature had stabilized. After installation, while the melter was idling, the temperature appeared to stabilize at $127^{\circ} \mathrm{C}$.

7.4 CONCLUSIONS

- The in-melter viewing system can continuously produce a clear picture for $1100 \mathrm{~h}$.

- The jet of steam directed across the aperture effectively removes crystallization and restores picture clarity.

- The air-cooled compound lens adequately withstands intense thermal heat.

- The use of a color synthesizer enhances the picture in a way that allows the monitoring technician to better analyze melter operations.

\subsection{RECOMMENDATIONS}

1. It is recommended that the extended operation of the melter viewing system be continued.

2. It is recommended that the increase in melter pressure, observed while steam cleaning the aperture, be minimized by testing the following modifications of the steam-cleaning procedure.

-- Restrict the time that the steam is in use to less than $10 \mathrm{sec}$.

-- Increase melter vacuum prior to steam cleaning.

-- Employ a series of $1 \mathrm{sec}$ or less steam additions to remove crystallization. 


\subsection{GLASS SAMPLING}

The molten glass stream flows through the discharge section, over the trough pour spout, and falls in a thin stream into a canister located below in the turntable. To periodically verify the composition of the glass product, a sampling device is used to collect a sample of this molten glass stream. The sampler is designed to be placed in an empty canister prior to filling and removed, along with a $35-\mathrm{mL}$ glass sample, after the canister is filled.

The sampler consists of a pivoting, counterweighted arm, to which a sample collection cup is attached. The pivoting arm is mounted on a frame that can be remotely installed or removed from the canister. Three centering tabs on the top ring of the sampler frame keep the sampler centered within the canister and flush with the canister neck. Figure 8-1 shows a sampler with lifting yoke and remote crane hook.

Before a canister is loaded into the turntable, the sampler is placed in the neck of the canister. When the canister is in position under the melter pour spout, the glass stream discharged from the melter is collected in the sample cup (Figure 8-2a). As the glass is collected in the sample cup, the increasing sample weight balances a counterweight on the opposite side of the arm pivot. When the weight of the sample balances the counterweight, the horizontal position of the arm becomes unstable. Additional sample causes the arm to deflect (Figure 8-2b) to the stable vertical position (Figure 8-2c). With the arm in the vertical position, the sample cup and arm are tucked under the shoulder of the canister, out of the path of the glass stream. A pivot on the sample cup prevents spillage of the sample during arm deflection.

After the canister has been filled, the sampler is removed from the neck of the canister and the glass sample is retrieved. This operation is done with use of a remotely operated crane using the sampler lifting yoke. When the sampler has been removed from the canister, the sample cup is detached from the sampler arm. This detachment is accomplished by lowering the sample cup into a transport cask/sample retainer, anchoring the sample cup, and then lifting the sampler and breaking the sample cup bail away from the sampler arm. When the bail breaks, the sample cup falls into the sample retainer/ transport cask and the remainder of the sampler is discarded. 

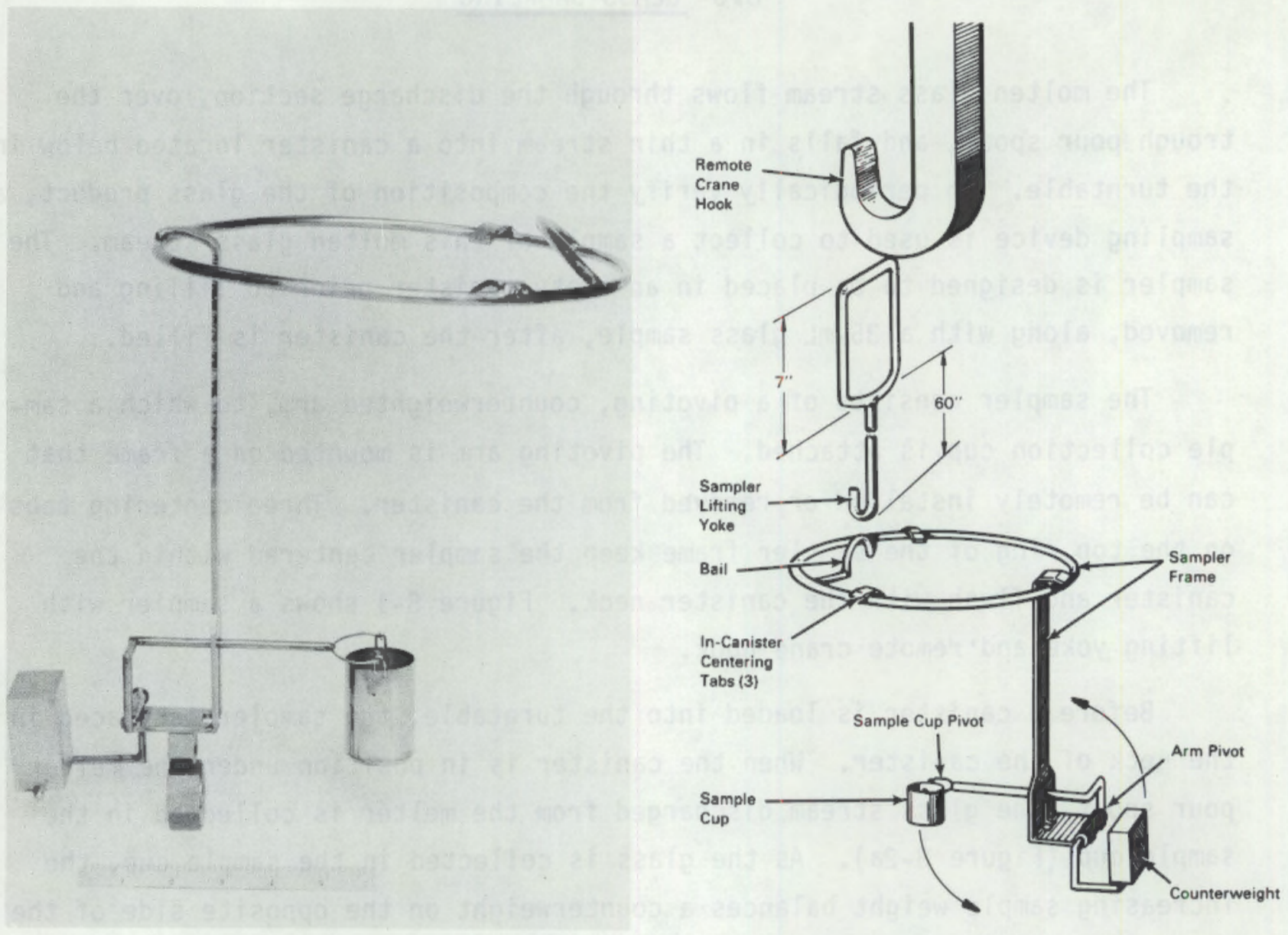

FIGURE 8-1. Sampler With Lifting Yoke and Crane Hook

a

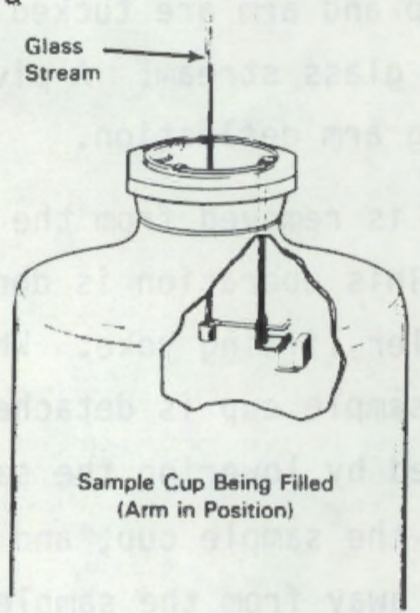

b

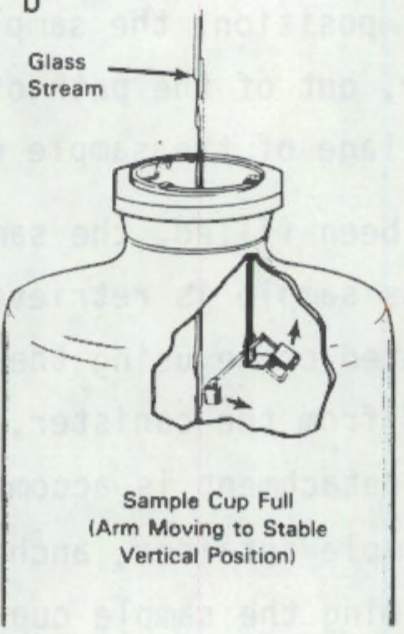

C

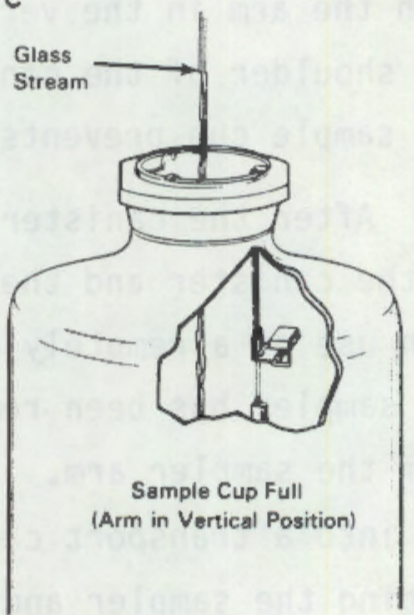

FIGURE 8-2. Sequential Positions of Sampler 
The feasibility of remotely obtaining a sample of the glass product stream was demonstrated in earlier concept verification tests. Based on design recommendations stemming from the results of previous testing, the purpose of this report is to evaluate an improved sampler design using the PNL remote operations testing facility.

\subsection{TEST EQUIPMENT}

A full-scale, prototype sampler and sample transport cask were built and tested. Figure 8-1 shows a photograph of the test prototype sampler. The mock turntable and a full-scale canister were also used in testing.

\subsection{TEST APPROACH}

To determine the minimum amount of sample that can be collected by the melt sampler, two experiments were conducted. In the first experiment, with the arm starting in the horizontal position, lead shct was added to the sample cup until the arm pivoted downward to the stable vertical position. The second experiment determined the minimum amount of weight needed to keep the sampler arm in the vertical position. The minimum weight of sample is predicted to be between these two weights.

Under normal operating conditions, the sampler will be installed in the neck of the canister before the canister is loaded into the turntable. However, it is possible that the sampler may need to be loaded into the canister after the canister has been placed in the turntable. This operation will require the use of a remotely operated crane and the sampler lifting yoke.

The stability of the sampler in the neck of the canister was also evaluated. During normal operating conditions, the canister is loaded into the turntable with the sampler in the canister. To determine whether or not the sampler might become misaligned in the canister during loading into the turntable due to incidental contact between the canister and turntable, a canister with a sampler installed was loaded to determine the consequences of incidental impact. 
In general, the feasibility of a remote operation is established by repetition of the operation, first with direct viewing and then with camera viewing. Successful repetition is the criterion by which the remote operation is judged. This standard approach was followed in evaluating the remotability of the sampler.

\subsection{RESULTS}

The two methods of determining the minimum sample weight produced different results as expected. The first method, where the sampler arm starts in the horizontal position and falls to the vertical position, an average sample weight of $97 \mathrm{~g}$ was recorded (target weight(a) was $100 \mathrm{~g}$, sample cup $2 / 3$ full of glass). The second method, where the arm was held in the vertical position and weight was added until the arm did not deflect back to horizontal position, yielded an average of $42 \mathrm{~g}$. This simulated the possibility that a large glob of glass (greater than $42 \mathrm{~g}$ but less than $97 \mathrm{~g}$ ) could hit the sample cup, in which case the momentum of this glob may cause the arm to swing to the vertical position. The conclusion is that, with the present design, less weight is required to maintain the sampler arm in the vertical position than to bring the arm from the horizontal to the vertical position. Although it requires only $42 \mathrm{~g}$ to maintain the arm in the vertical position, this amount of weight does not result in a very stable configuration. Because of the instability of the vertical arm position with a sample weight of $-42 \mathrm{~g}$, and the fact that the arm would have a tendency to bounce when it reaches the vertical position, it is likely that a greater sample weight will be collected.

Installation of the sampler into the canister using the crane and sampler lifting yoke was performed without difficulty (Figures 8-3 and 8-4). The present sampler design slips easily into the canister. The length of the sampler lifting yoke provides adequate clearance for good remote TV viewing.

Loading of the canister, with sampler installed, into the turntable using the canister lifting yoke worked very well (Figure 8-5). The melt sampler does not interfere with the operation of the canister grapple. Also, the stability of the sampler while in the neck of the canister is very good. Even after several hard impacts while loading the canister, the sampler remained 


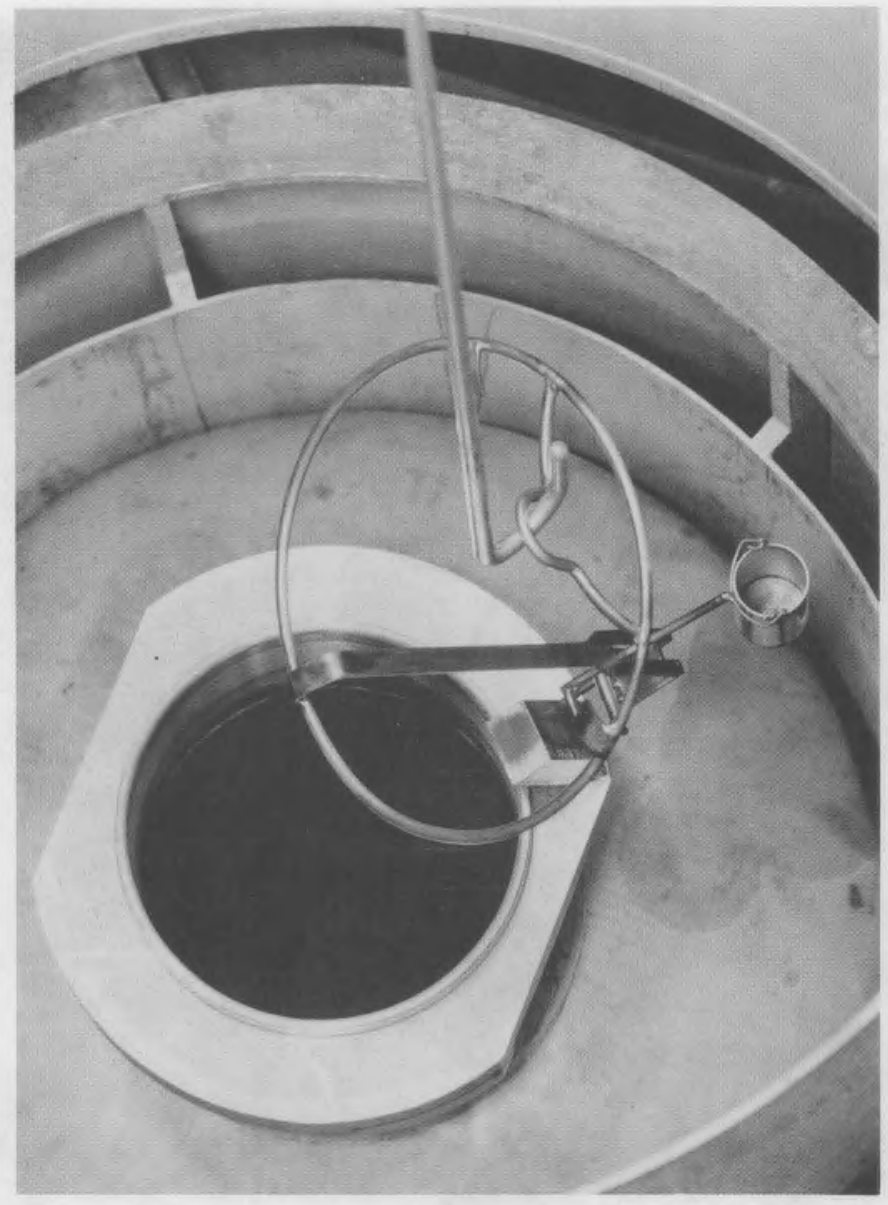

FIGURE 8-3. A Sampler Installation into Empty Canister Using Crane and Lifting Yoke

centered in the canister neck and showed no signs of becoming unseated or misaligned within the canister.

Removal of the loaded melt sampler from the canister was performed without difficulty. As during the installation of the melt sampler with the sampler lifting yoke, the crane operator has an adequate view of the sampler during removal using the remote TV cameras.

During separation of the sample cup from the sampler arm (Figure 8-6), the outer edge of the sample retainer/transport cask and the pivot of the sampler interfered with each other and prevented the sample cup from entering the 


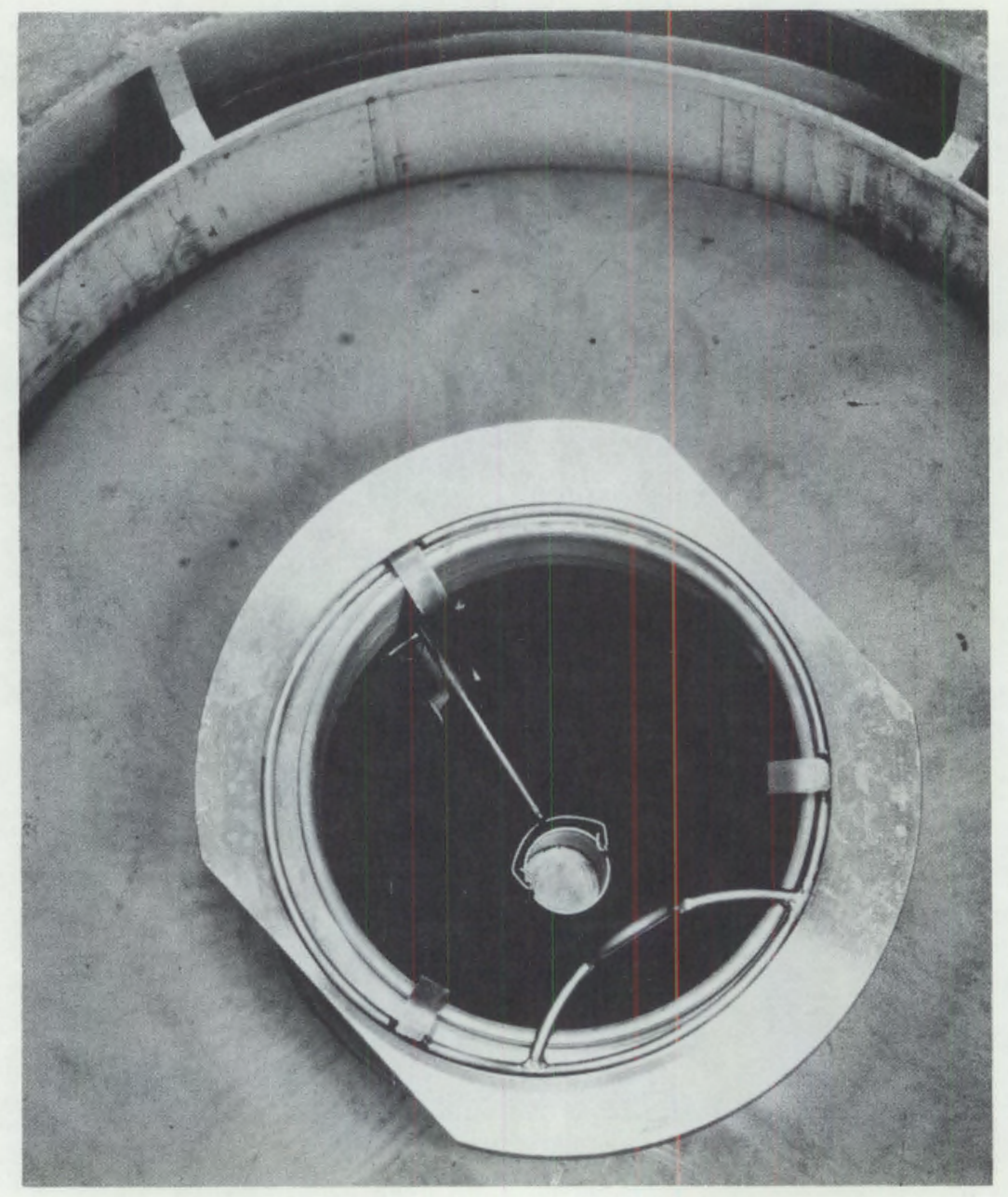

FIGURE 8-4. Top View of Canister Containing Remotely Installed Sampler

hole. Crane operation does not provide enough control over sampler orientation to place the sample cup in the hole of the sample retainer/transport cask with the present design of melt sampler. The test was completed by guiding the sample cup into the hole by hand and using the crane to separate the cup from the arm. This was not considered a serious problem because, during testing of an earlier model of the melt sampler, the cup was successfully separated from the sampler arm using only the crane for guiding the cup into the hole.

The problem can be solved: a) by redesigning the sampler such that the pivot does not interfere with the present sample retainer/transport cask design, or b) by enlarging the diameter of the sample retainer/transport cask 


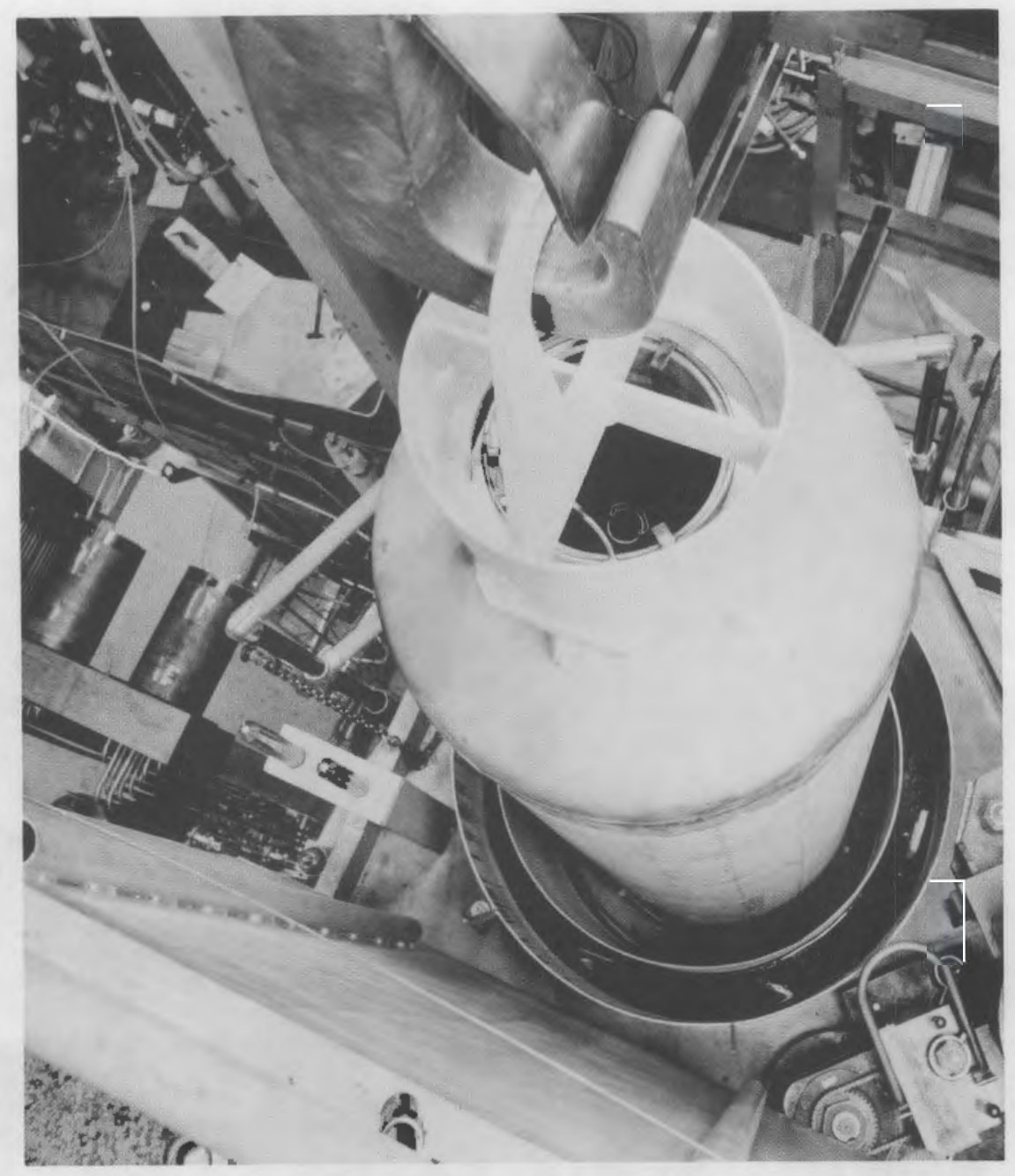

FIGURE 8-5. Loading of Canister into Turntable With Sampler Pre-Installed

such that the pivot does not interfere with edge of the cask, or c) the most practical way, by reducing the depth of the guide surface of the sample retainer/transport cask such that the cup enters the hole before the pivot touches the edge of the cask.

\subsection{CONCLUSIONS}

- Sample weight range achievable with the sampler prototype is $42 \mathrm{~g}$ to $97 \mathrm{~g}$. During actual use of a sampler, the minimum weight of the sample obtained will probably be higher than $42 \mathrm{~g}$ due to the instability of the sampler arm with this weight of sample in the cup. 

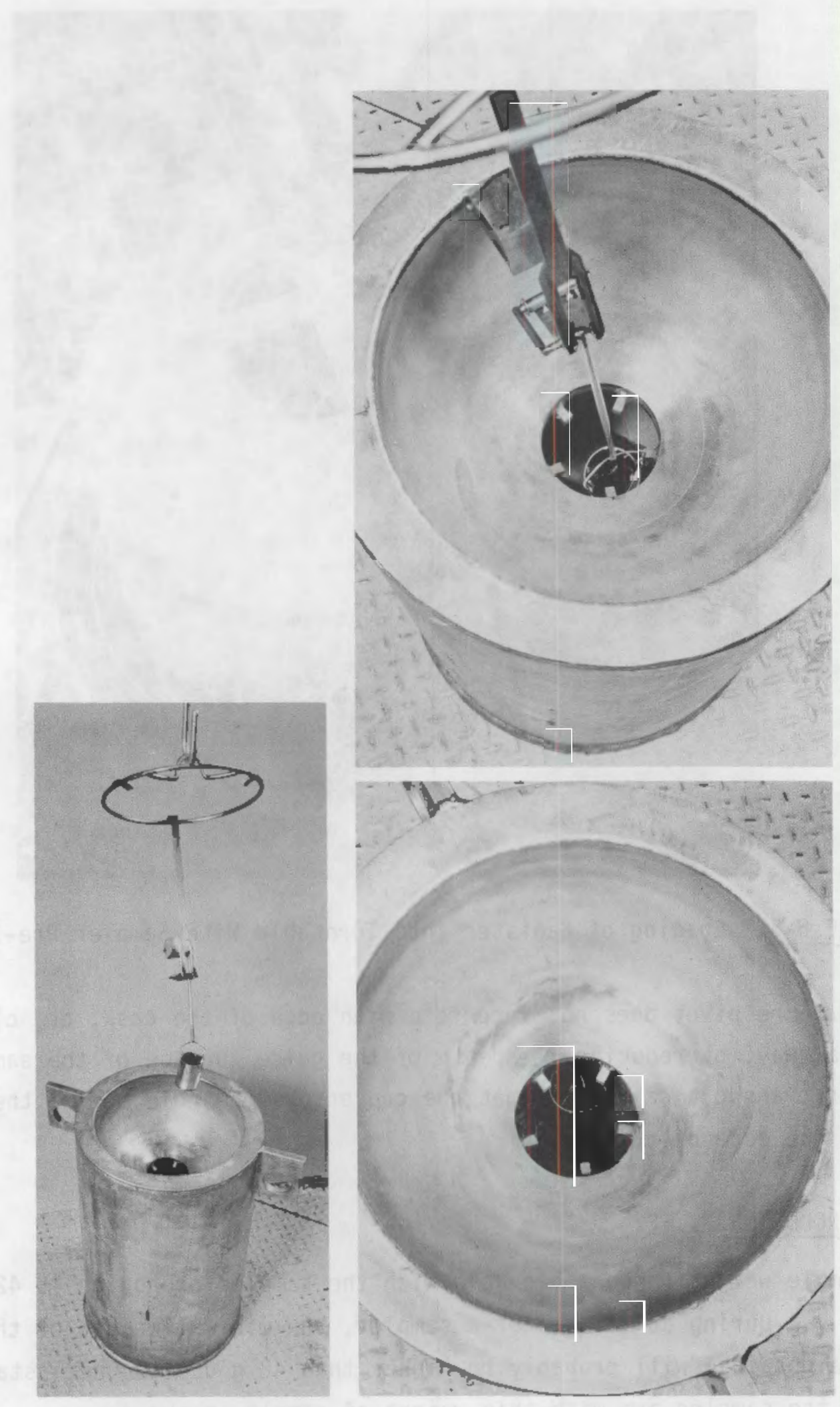

FIGURE 8-6. Lowering Sampler into Sample Retainer/Transport Cask 
- Installation and removal of the melt sampler from a canister using the crane and sampler lifting yoke is easily accomplished. Visibility of the sampler and canister using the remote TV cameras for this procedure is adequate.

- The melt sampler does not interfere with the operation of the canister grapple, or vice versa.

- The stability of the melt sampler in the neck of the canister is excellent. Impact during loading (the most severe impact encountered by the sampler) did not cause the sampler to become misaligned or dislodged from the canister.

- Removal of the sample cup from the sampler arm using a remotely operated crane can be accomplished with slight modification of either the melt sampler or sample retainer/transport cask.

\subsection{RECOMMENDATIONS}

1. The bail on the melt sampler should be modified to ease the centering of the melt sampler on the lifting bail (Figure 8-7).

2. The sampler lifting yoke should be designed with a curved contact point to prevent twisting on the crane hook (Figure 8-7).

3. The depth of the guide surface on the sample retainer/transport cask should be decreased to provide adequate clearance for the glass sampler. 

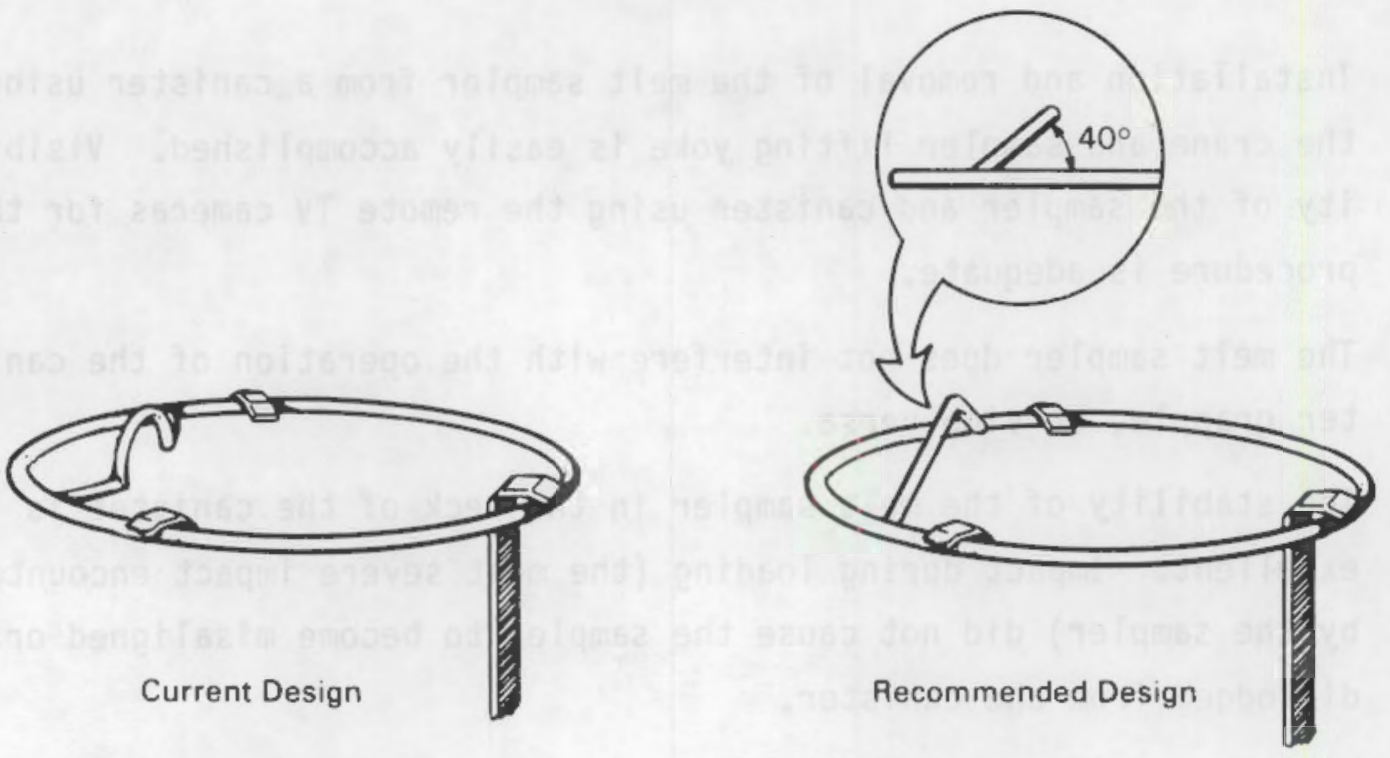

Sampler Lifting Bail Modifications

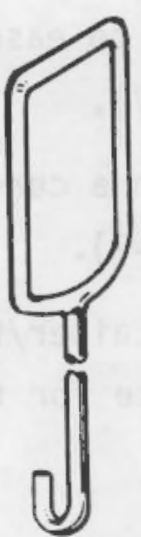

Current Design

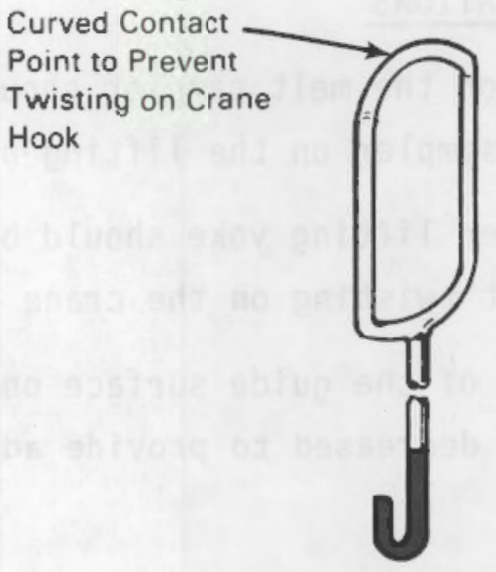

Pecommended Design

FIGURE 8-7. Recommended Sampler Modifications 


\subsection{MELTER NOZZLE MAINTENANCE}

The melter feed slurry consists primarily of glass formers, radioactive salts, and water. While the solid glass formers and radsalts remain in the melter, the volatile feed components are vaporized and, along with entrained feed particles, leave the melter through an off-gas nozzle. Some of the entrained particles are deposited on the walls of the nozzle and, with time, build up a tough, ceramic-like coating that could eventually clog the melter nozzle. Other melter nozzles, employed variously as viewports or as access ways to instrument sensors, may also become clogged.

The function of the nozzle maintenance system is to remove the blockage from a clogged nozzle so that the nozzle can be reconnected for service. A nozzle cleaning device has been designed to be installed, operated, and removed remotely.

The nozzle cleaner consists of a core drilling apparatus that is lowered by crane onto an open melter nozzle. A flange on the nozzle cleaner fits over guide dowels and threaded studs that are on a flange of the melter nozzle. The cleaner is then remotely bolted into place (Figure 9-1). A drill feed mechanism lowers a rotating, diamond-surfaced bit (standard core drill) into the nozzle. The bit cuts a core through the blockage and thus unclogs the nozzle. At the point where the rotating bit cuts through the blockage and enters the melting cavity, the drill feed mechanism automatically reverses and lifts the bit out of the nozzle. When the bit is clear of the nozzle, power to the assembly is disconnected and the nozzle cleaner is remotely removed from the melter. The bit is designed to operate continuously at $290^{\circ} \mathrm{C}$ but can withstand up to $430^{\circ} \mathrm{C}$ for short periods.

For these tests it was assumed that the melter would be in idling mode and at a $\sim 5$ in. vacuum (through a secondary off-gas nozzle) during the nozzle cleaning operation. Under these conditions, air will leak in past the rotating bit and provide cooling during the cut and pull some of the cuttings (powder) out of the drill area. Two other cooling concepts were being considered to ensure sufficient cooling. First, air can be forced through the cutting area by means of pressurized air through a sealing flange around the rotating drill bit. Second, water can be directed along the outer periphery 


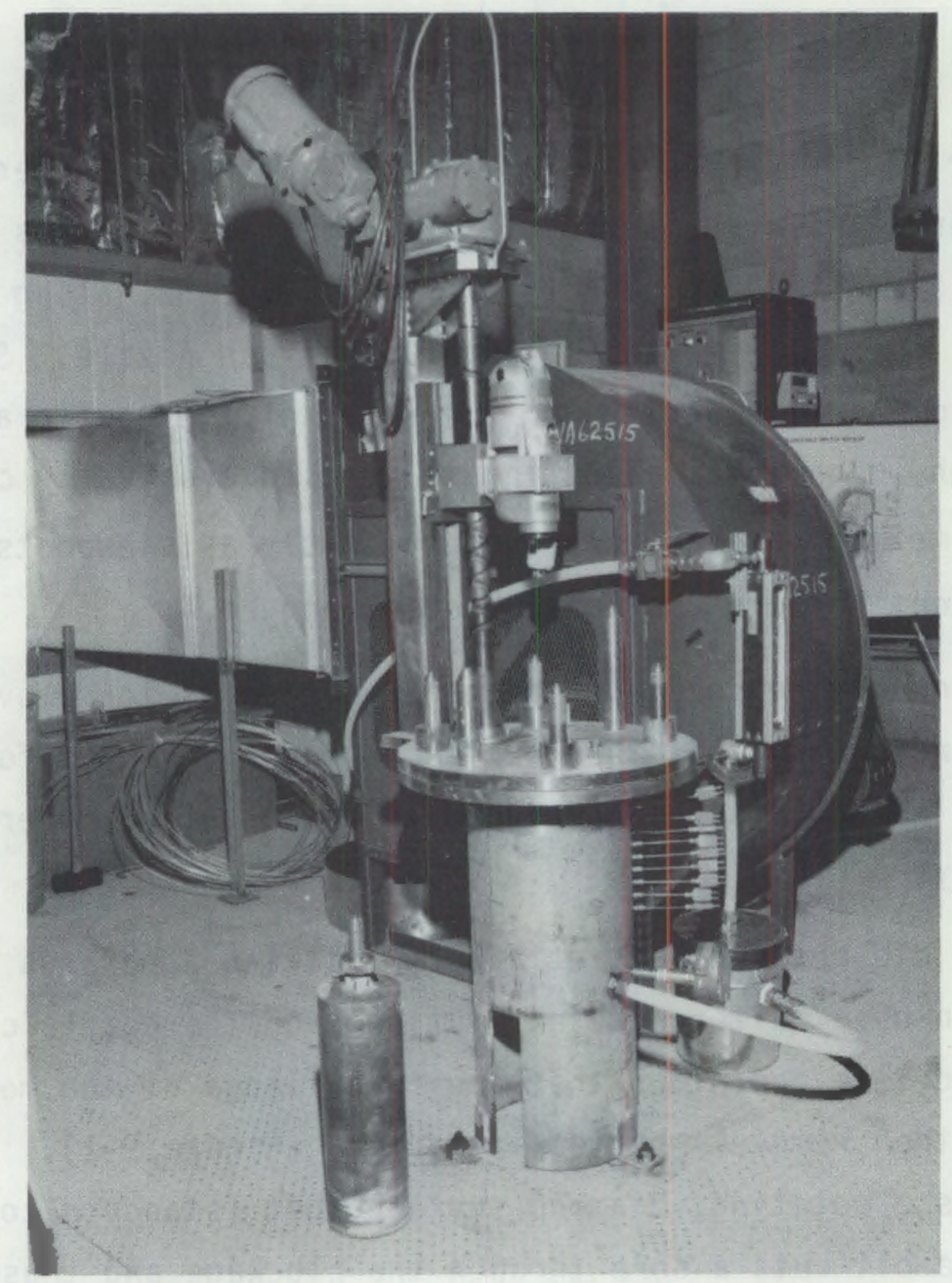

\section{FIGURE 9-1. Melter Nozzle Cleaner}

of the bit and allowed to gravity-flow through the cutting area. Since both of these alternatives involve the added complexity of a service line, naturally occurring inleakage air is preferable, provided the melter is maintained at a sufficient vacuum.

Other tests demonstrated the remote installation and removal of the prototype nozzle cleaner device from a mock melter off-gas nozzle. In addition, early testing with an air vacuum system also demonstrated the need for removal of dust and debris from the cut area. 


\subsection{TEST EQUIPMENT}

A full-scale, operational prototype of the nozzle cleaning device was employed for testing. A mock nozzle, incorporated into a test stand, was constructed in accordance with the materials and dimensions as planned for the proposed HWVP melter. Figure $9-2$ is a photograph of the nozzle cleaner test stand.

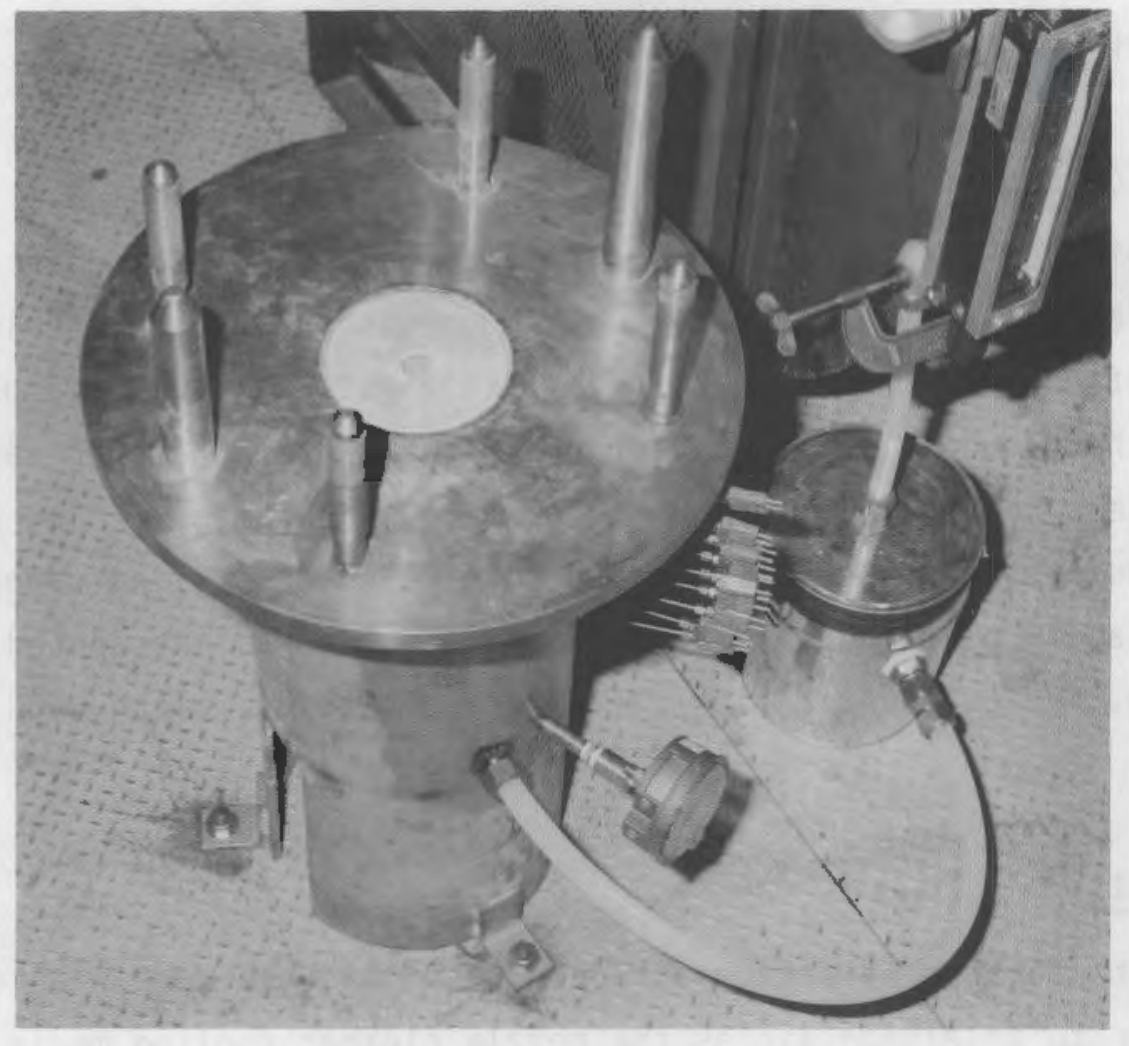

FIGURE 9-2. Nozzle Cleaner Test Stand

To simulate a nozzle blockage, castable ceramic material was poured into the mock nozzle and formed in the shape of a blockage. The simulated blockage was a 6-in.-dia. x 16-in.-long cylinder, with a 1-in.-dia. center hole. The center hole was left because it was assumed that reduction of the off-gas flow would be detected and cleaning would be required before the nozzle became fully clogged. A $1-i n$. hole in a $6-i n$. nozzle represents a $95 \%$ reduction in the nozzle cross-sectional area, and is considered a "worst case" clog. Therefore, the simulated blockage in the test stand is anticipated to represent "worst case" conditions. 
Alfrax $66^{\circ}$ was selected to simulate the melter blockage material because it could be easily cast within the mock nozzle, had good adherence, and formed a tough ceramic when cured. How closely the Alfrax 66 simulated the actual blockage material is not known, since necessary information about the properties of that material is not available.

Temperatures along the cutting edge were monitored at nine discrete points during the test using thermocouples imbedded in the simulated plug as shown in Figure 9-2. The thermocouples were inserted to a depth such that the drill bit passes by the edge of the thermocouple.

\subsection{TEST APPROACH}

Two-bit cooling cases were evaluated. First, for the case where only melter inleakage provides cooling, a vacuum was applied to the lower cavity in the test stand. The resultant air inleakage rate was measured using a rotameter in the vacuum line. A filter upstream of the rotameter was used to clear powder from the air for good flow rate measurement. Flow rate and test stand vacuum were monitored. Second, for the water cooling case, the test stand was again operated at a vacuum, while water was introduced into the cut at $1.5 \mathrm{gph}$. Water and air flow rates were monitored, along with test stand vacuum.

\subsection{RESULTS}

Results for the inleakage-air-only case, and the case with cooling water in addition to inleakage air as the nozzle cleaner cooling media, are described in the following two subsections.

\subsubsection{Air Cooling}

Air inleakage rates decreased during the cutting process from an initial value greater than $300 \mathrm{cfm}$ to a final value of $140 \mathrm{cfm}$. The extent of vacuum in the nozzle test stand varied from an initial value of $-1-i n . H_{2} \mathrm{O}$ to a stable value of $-10-i n$. $\mathrm{H}_{2} \mathrm{O}$, occurring $8 \mathrm{in}$. (halfway) into the nozzle.

- Alfrax is manufactured by the Carborundum Company, Keasbey, New Jersey. 
Table 9-1 lists the high temperatures of each of the cutting edge thermocouples, spaced 1 in. apart, as shown in Figure 9-2. The high temperatures correspond to the points where the bit passes nearest a thermocouple. Elapsed times between high temperatures are also given to indicate the rate of progress of the cleaning operation.

TABLE 9-1. Cutting Edge Temperature with Air Cooling

Thermocouple Number

1
2
3
4
5
6
7
8
9

\begin{aligned} Depth \\ \hline \\ 4 in. \\ 5 in. \\ 6 in. \\ 7 in. \\ 8 in. \\ 9 in. \\ 10 in. \\ 11 in. \\ 12 in. \end{aligned}

High Temperature Elapsed Time $48.8^{\circ} \mathrm{C}$ $47.4^{\circ} \mathrm{C}$ $54.3^{\circ} \mathrm{C}$ $55.9^{\circ} \mathrm{C}$ $61.4^{\circ} \mathrm{C}$ $69.7^{\circ} \mathrm{C}$ $81.9^{\circ} \mathrm{C}$ $75.8^{\circ} \mathrm{C}$ $94.3^{\circ} \mathrm{C}$
14 min.
$8 \mathrm{~min}$.
9 min.
$8 \mathrm{~min}$.
10 min.
$15 \min$.
10 min.
$8 \mathrm{~min}$.

Progress was impeded somewhat between depths of 9 in. to 11 in., and again between depths of $14 \mathrm{in}$. to $16 \mathrm{in}$., due to seizing of the bit in the powder that was generated during drilling. This was alleviated by reversing the bit feed for $\sim 1 \mathrm{~min}$, and allowing the air to pull the powder into the mock melter before drilling was resumed. The overall cutting process required $2.5 \mathrm{~h}$. The cutting edge temperature dropped to between $\sim 38^{\circ} \mathrm{C}$ at thermocouple \#1 to $46^{\circ} \mathrm{C}$ at thermocouple \#9 when the bit was cutting in the lower 2 in. of the blockage.

During the test, the drill bit feed rate was measured as $1 / 8-i n . / m i n$. After cutting through, the cored-out blockage fell intact from the bit, as anticipated. Figure $9-3$ is a photograph of blockage material removed from the test stand on three occasions. The lack of damage to the refractory lining the nozzle after the cleaning operation indicated cutting pressures, and thus bit feed rate, are acceptable.

After the cleaning operation, $2262.8 \mathrm{~g}$ of powder and debris were removed from the base of the test stand, while $988 \mathrm{~g}$ of fine powder were removed from the vacuum line filter. 

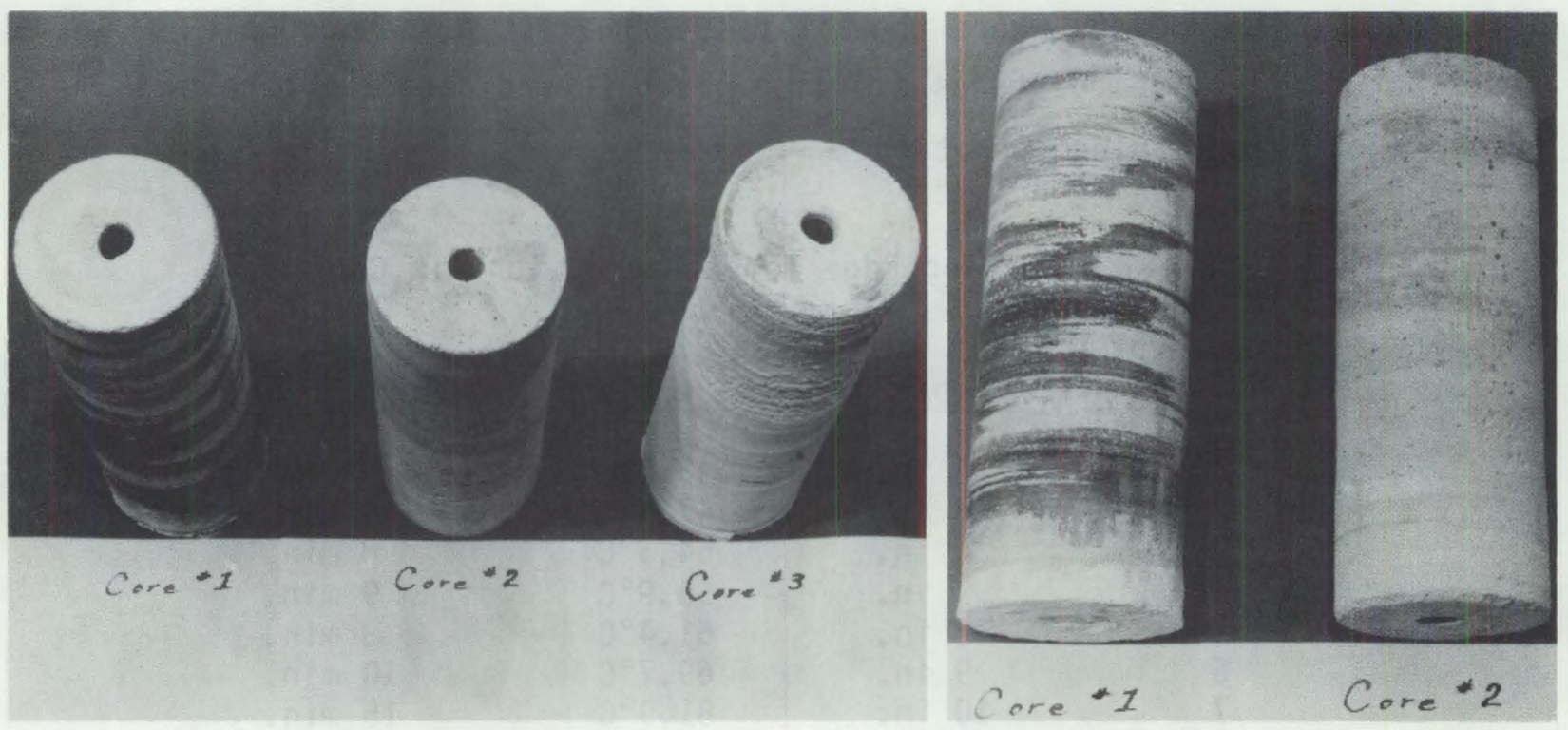

FIGURE 9-3. Blockage Core Removed from Test Stand

\subsubsection{Water Cooling}

The water flow rate was held constant at $1.5 \mathrm{gph}$ throughout the second cleaning operation, which also used a cast nozzle blockage. During the test, air inleakage rate decreased from $230 \mathrm{cfm}$ to $150 \mathrm{cfm}$, and down to $40 \mathrm{cfm}$ at the last inch of the cut. That the water effectively cooled the bit is illustrated by the cutting edge temperatures which were maintained at $15^{\circ} \mathrm{C}$ to $20^{\circ} \mathrm{C}$ throughout the test as compared to those above $90^{\circ} \mathrm{C}$ in the air-cooling test. Seizing of the bit occurred only once during this second cutting operation--at the final $\sim 1 / 2 \mathrm{in}$. of the cut, possibly due to movement of the core material. This is to be compared to the frequent seizing experienced in the air-only test.

As with the air-only test, no damage was incurred by the nozzle liner refractory, indicating proper bit feed rate.

During initial cutting, the wobble, or eccentricity associated with the rotating bit, was estimated as $3 / 16 \mathrm{in}$. The inner diameter (ID) of the nozzle, after reaming, is dependent on both the eccentricity of the bit and debris-induced grinding. Figure $9-4$ is a plot of the nozzle ID as a function of location along the vertical ( $Z$ ) axis of the nozzle. 


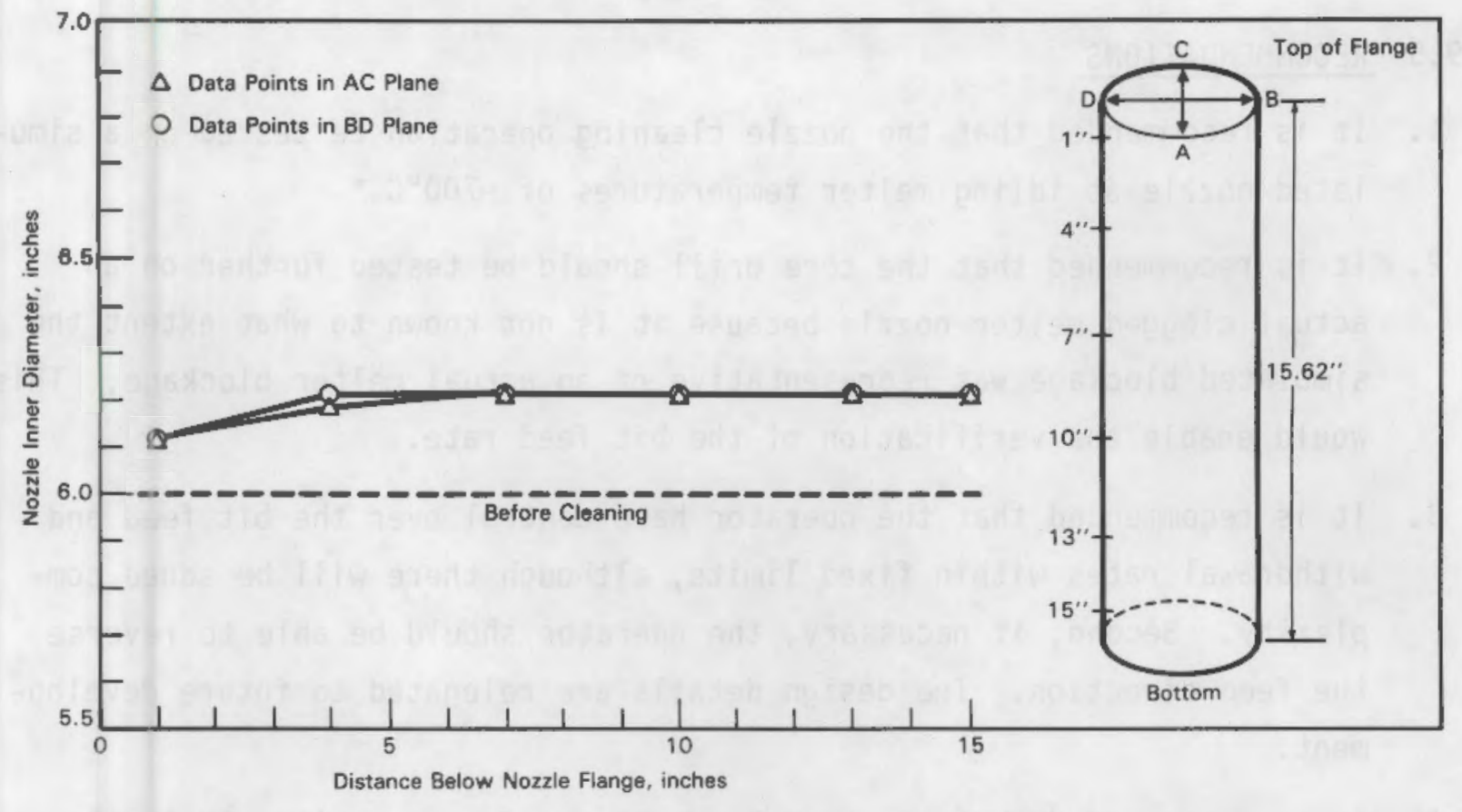

FIGURE 9-4. Nozzle Inner Diameter After Cleaning as a Function of Location

\subsection{CONCLUSIONS}

- A water flow of $1.5 \mathrm{gph}$ into the test nozzle under vacuum is sufficient for trouble-free nozzle cleaning operations.

- Air inleakage at a test stand vacuum of $-10-i n$. $\mathrm{H}_{2} \mathrm{O}$ provided insufficient air flow to prevent bit seizure (see footnote on following page).

- Bit seizure can be overcome by reversing the bit $\sim 1 / 8$ in. and restarting the bit drive motor.

- A bit feed rate of $1 / 8-i n . / m i n$ is considered acceptable. It may be beneficial to lower the feed rate even further in the air-only case. 


\subsection{RECOMMENDATIONS}

1. It is recommended that the nozzle cleaning operation be tested on a simulated nozzle at idling melter temperatures of $\sim 700^{\circ} \mathrm{C} .{ }^{*}$

2. It is recommended that the core drill should be tested further on an actual clogged melter nozzle because it is not known to what extent the simulated blockage was representative of an actual melter blockage. This would enable the verification of the bit feed rate.

3. It is recommended that the operator have control over the bit feed and withdrawal rates within fixed limits, although there will be added complexity. Second, if necessary, the operator should be able to reverse the feed direction. The design details are relegated to future development.

4. It is recommended that a method be developed for measuring either the cutting pressure or temperature during operation. This information would enable the operator to select the proper feed rate and identify problem areas within the nozzle. Adding this capability could help prevent damage to both the nozzle reamer and the refractory material within the melter. In addition, it is suggested that an up/down indicator is needed to determine the direction of feed unambiguously.

5. It is recommended that future bits be $\sim 1 / 2-i n$. in dia smaller than the nozzle itself. This would make alignment of the nozzle reamer less critical. Of course, the nozzle would have to be 1/2-in.-dia. larger than necessary to maintain the required inner diameter.

* NOTE: Inspection of the nozzle reamer after testing indicated the diamond matrix at the cutting edge of the bit to require cleaning. After cleaning the bit, further testing was performed. The test was run with the test stand mounted on a furnace maintained at $700^{\circ} \mathrm{C}$ and at a -5 in. $\mathrm{H}_{2} \mathrm{O}$ vacuum. In this test, air inleakage, estimated as $18 \mathrm{scfm}$, was found to provide sufficient bit cooling, allowing the cleaning operation to proceed without difficulty. 


\subsection{CANISTER LEVEL DETECTION SYSTEM}

During the canister filling process, a gamma-level detection system will be used to monitor the increasing volume of glass within the canister being filled. This system, in conjunction with the canister weighing system described in Section 2.0, comprises an important process control tool. With the weight and volume of glass being monitored, the density of the glass, as well as the extent and uniformity of the filling process, can be determined.

The preconceptual level detection system consists of an array of $\gamma$-ray detectors that are mounted in the cell wall (gallery side) and an $\gamma$-ray source within the cell. The detector array, radiation source, and the canister being filled are aligned with the canister interposed between the source and the detector array. As the interposed canister is filled, the vitrified waste product reduces the intensity of the $\gamma$-rays that pass through it from the $\gamma$-ray source to the detectors. This source attenuation can be detected and used to establish to what extent the canister is filled with glass. The vertical array of detectors allows the presence of glass to be verified at several discrete levels within the canister.

Two methods of providing a detectable source for the in-cell system have been considered. The first involves installing a single source which spans the length of the canister $(\sim 10 \mathrm{ft})$. The second involves mobilizing a smaller source so that it moves vertically, up and down the length of the canister, and is visible to each detector periodically, rather than continuously. Both methods are considered feasible.

Testing to-date has demonstrated the ability of a $\gamma$-ray source/detector system to detect the level of glass within a canister. Cobalt-60 was identified as an appropriate $\gamma$-ray source, and an NaI $\gamma$-ray scintillation device was found to function well as the detector. In this report, the in-cell portion is a device for positioning a small $\gamma$ source. The device is evaluated with respect to remote handling and operation. 


\subsection{TEST EQUIPMENT}

The source-positioning device consists of a source holder linked to an actuator shaft. As the actuator shaft is rotated by a motor, the source holder traverses the vertical axis of the shaft. Figure 10-1 is a drawing of the prototype source mobilizing device as built and tested. Although the in-cell device is designed to cycle the source upward and downward along a travel distance that corresponds to the product stream path (descending from the trough pour spout to the bottom of the canister being filled), the test prototype features a much shorter travel. This dissimilarity does not invalidate the remotability evaluation; the overall physical dimensions of the prototype source-positioning device are in complete accordance with the conceptual in-cell device.

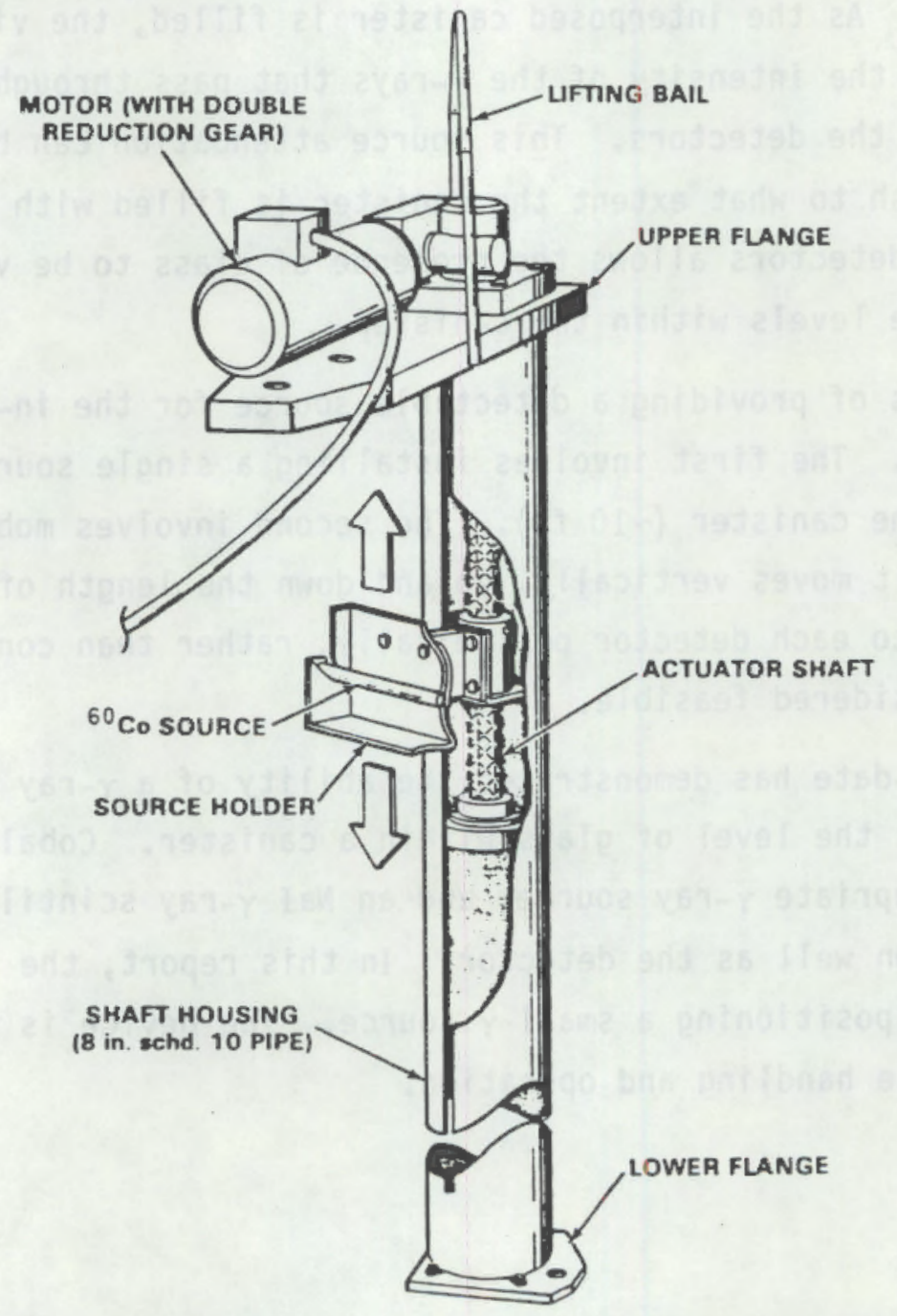

FIGURE 10-1. In-Cell Cobalt-60 Source Positioning Device 


\subsection{TEST APPROACH}

First, the remote installation of the source-positioning device was tested. The device was lowered by crane (via a lifting bail located on the surface of the upper flange of the device) onto two doweled flanges that are attached to the turntable. Once installed, operation of the device was observed. The actuating motor was run continuously, allowing several up and down cycles of the source holder to be observed. After observing extended operation, the source-positioning device was removed by crane from the doweled flanges attached to the turntable mockup. To complete the test, the sourcepositioning device was remotely installed, operated, and removed two additional times. Since the source-positioning and the $\mathrm{CO}^{60}$ source it carries are located outside of the turntable in the ambient cell environment, high temperature related problems are not expected and were therefore not simulated. Testing was done at room temperature $\left(22^{\circ} \mathrm{C}\right)$.

\subsection{RESULTS}

The remote handling operations were performed without difficulty three times, thus demonstrating the remotability of the source positioning device. Figure $10-2$ is a composite photograph of the device installed on the turntable in the PNL remote operations test facility.

The operation testing of the device was also performed without difficulty. The movement of the source holder by the motor/actuator shaft system was observed for an $\sim 4-h$ period and is characterized as being smooth throughout the up and down cycle. The rate of travel of the source was measured as $1-1 / 16 \mathrm{in.} / \mathrm{min}$.

\subsection{CONCLUSIONS}

- The source mobilizing device is well suited to remote installation and operation.

- With the motor/actuator shaft configuration as designed, the source housing travels at a smooth rate of $1-1 / 16 \mathrm{in./min}$ up and down the shaft. 


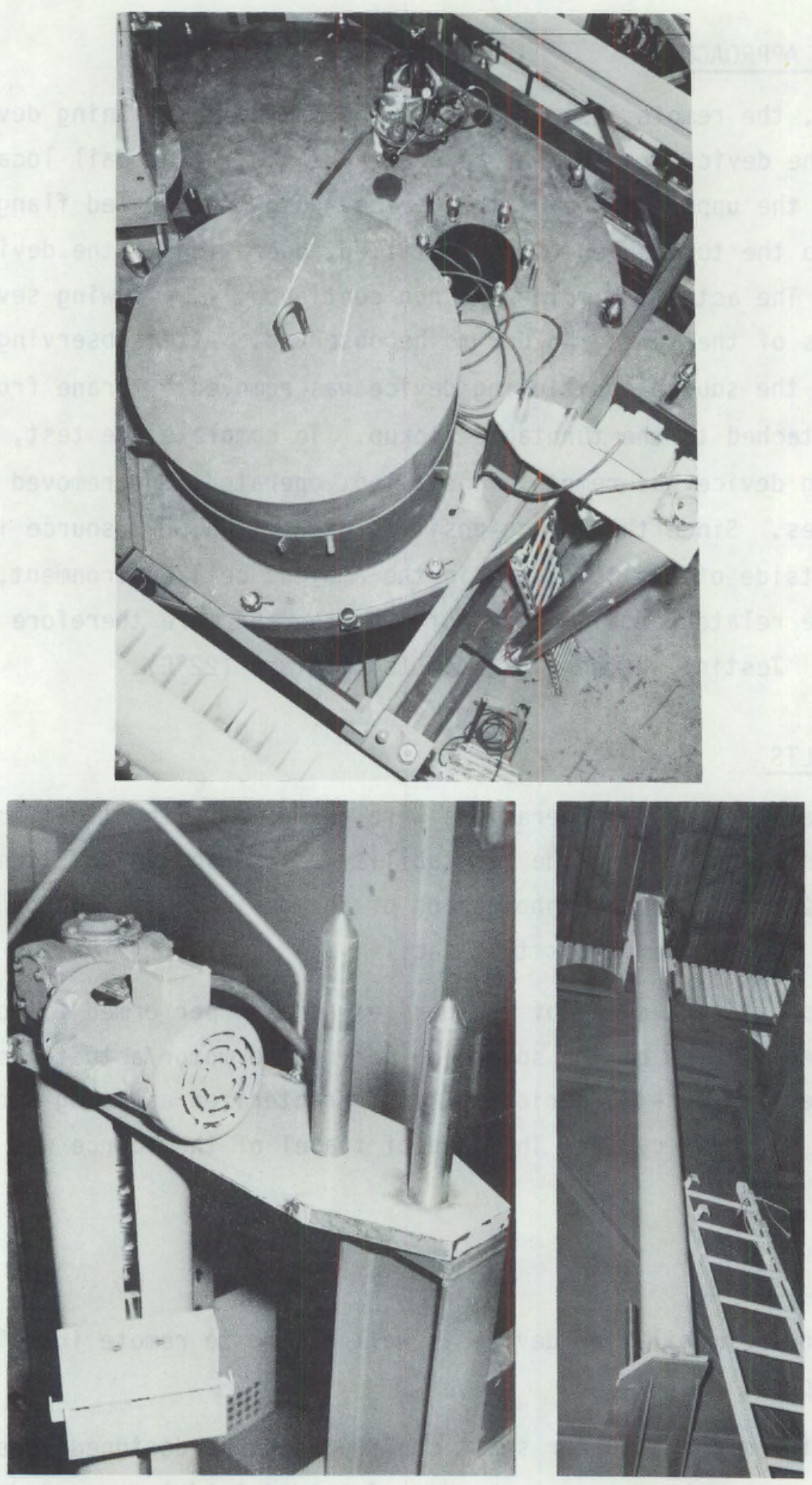

FIGURE 10-2. Cobalt-60 Source Positioning Device 


\subsection{RECOMMENDATIONS}

1. Due to the successful demonstration of the source mobilizing device, there are no recommendations regarding design changes or further testing requi rements. 


\subsection{LIQUID METAL SEAL EVALUATION}

Prior to development of the bellows seal to provide an airtight connection between the melter and the turntable, a liquid metal seal was being considered for use. The purpose of this seal is to provide an airtight connection between the melter and turntable during process operations. Air inleakage into the melter/turntable system needs to be minimized to prevent cooling of the pouring glass stream and minimize power usage for air inleakage heating. The seal need be capable of periodic separation to enable melter and/or turntable removal for replacement or maintenance.

Flanged or clamping devices are used to connect hardware components used in vitrification processes. When these types of components are remotely assembled in a cell, installation is normally facilitated by the use of manipulators and/or a crane. Remote assembly via a sealed slip-joint arrangement (Figure 11-1) may reduce overall assembly time considerably and be useful where access by manipulators is difficult. Selecting seal for a slip-joint assembly becomes difficult due to the wide and differential temperature range

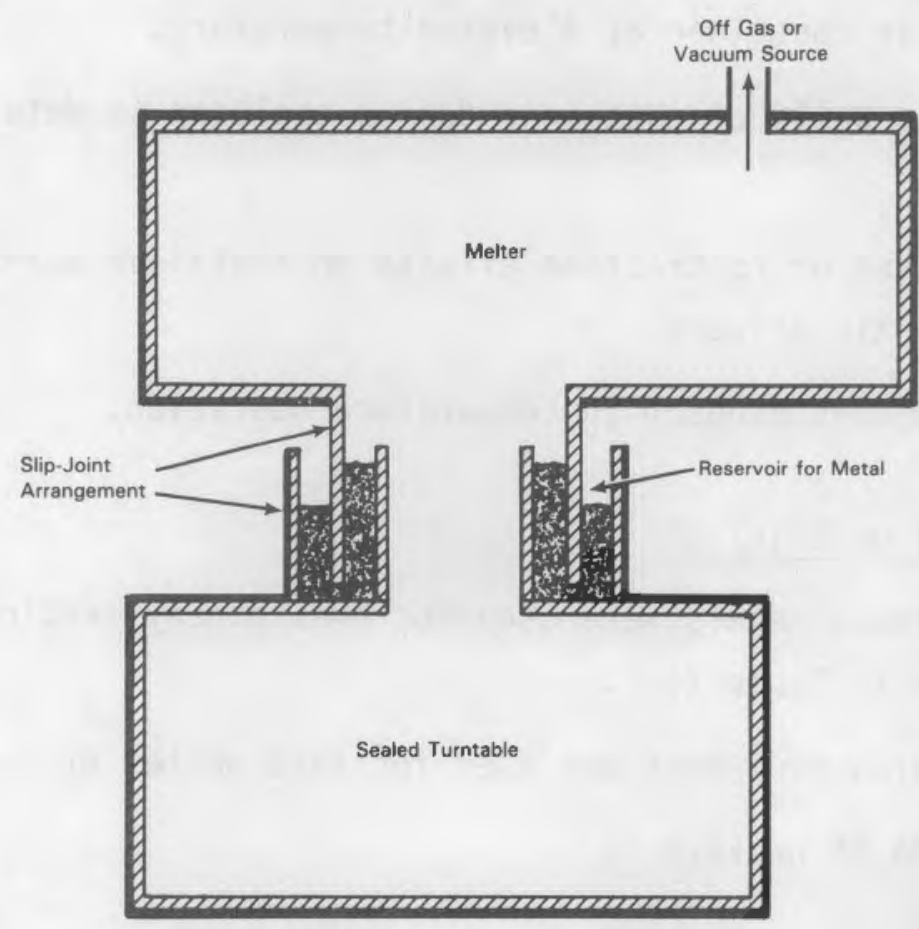

FIGURE 11-1. Slip-Joint Arrangement for Remote Sealing 
range that the mating components are subjected to during operation. Various types of liquid or low-melting-point metals may be the solution to making this slip-joint arrangement a viable option to flange connections. This slip-joint arrangement may also reduce design problems inherent with thermal expansion of the various components during operation. Metals are being considered for use instead of other liquids due to their high density (minimum depth needed to maintain differential pressure) and high boiling point.

The use of liquid metal is unique in making seal joints between various in-cell hardware components. Sufficient questions have been raised concerning its use components in the joule-heated glass melter to necessitate an investigation of the following properties:

- ability to form an airtight seal between metal components

- melting point

- volatilization at elevated temperatures

- density changes at elevated temperatures

- phase separation due to heat

- corrosion of container at elevated temperatures

- adhesion to walls of container during cooldown to determine seal quality

- expansion and/or contraction effects on container during heat cycling (stress/strain effects)

- effects of continuous high-temperature operation.

\subsection{EQUIPMENT DESCRIPTION}

Four candidate metals were used for preliminary testing. The compositions are given in Table 11-1.

The following equipment was used for this series of tests:

- $500 \mathrm{~mL}, 304$ SS beakers

- hot plates 
TABLE 11-1. Composition of Metals Used in Preliminary Testing

\begin{tabular}{|c|c|c|c|c|c|}
\hline \multirow[b]{2}{*}{ Chemical } & \multicolumn{5}{|c|}{ Composition, \% } \\
\hline & Metal & $\begin{array}{l}\text { Specialties } \\
\# 158-190\end{array}$ & $\frac{\text { Inc. Alloys }}{\# 255}$ & $\frac{\text { Lipowitz }}{\# 2505}$ & $\frac{\text { Woods Metals }}{\# 158-165}$ \\
\hline $\begin{array}{l}B i \\
P b \\
\text { Sn } \\
C d\end{array}$ & & $\begin{array}{r}42.5 \\
37.7 \\
11.3 \\
8.5\end{array}$ & $\begin{array}{l}55.5 \\
44.5\end{array}$ & $\begin{array}{l}50.0 \\
26.7 \\
13.3 \\
10.0\end{array}$ & $\begin{array}{l}50.0 \\
25.0 \\
12.5 \\
12.5\end{array}$ \\
\hline
\end{tabular}

- micrometers and calipers for expansion measurements

- calibrated thermometer

- scales to determine weight loss

- vacuum/pressure gauges and flowmeters

- thermocouples and recorder.

The metal containment seal test apparatus is shown in Figure 11-2.

\subsection{APPROACH}

Four SS beakers were fitted with thermocouples and air tubes (Figure 112b). Caliper measurements of the beaker diameters were recorded. Initial metal volume and weights were recorded. A hot plate was used as the heat source. General observations were made during the course of specific testing of container distortion, color change, surface oxidation due to varying temperatures, and rapidity of metal to become liquid at its observed melting point. The ability of the solidified metal to become liquid at its observed melting point. The ability of the solidified metal to form a seal was measured by drawing a vacuum on a SS tube inserted in the metal. The tendency of the metal to phase separate or corrode the beaker also was to be observed. The metals were cycled through three melting/cooling cycles. On the third cycle the metal was maintained in a molten state for observation before it was allowed to solidify. 
a

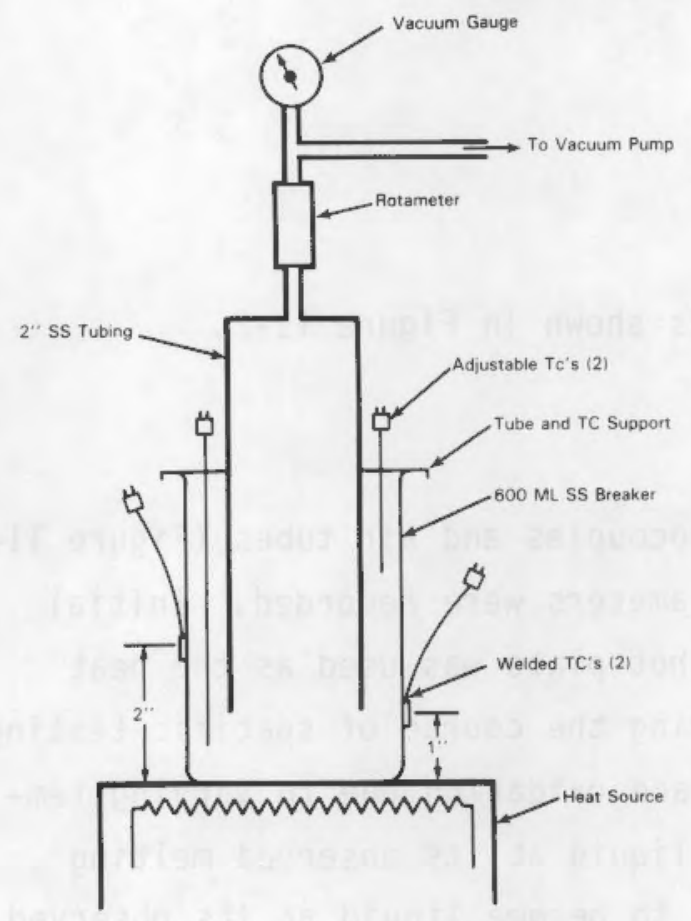

b

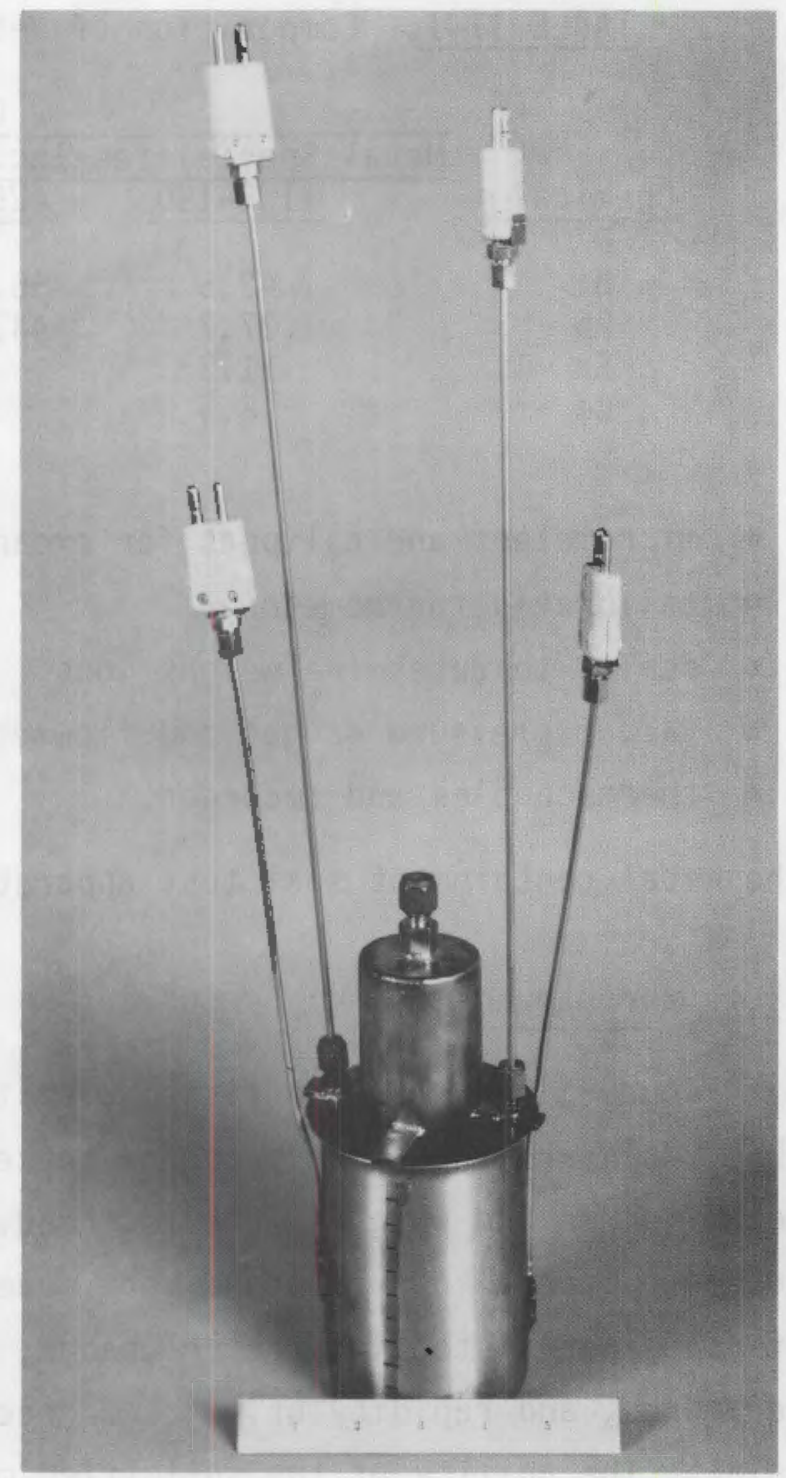

FIGURE 11-2. Metal Containment Seal Test Apparatus

\subsection{RESULTS}

The tests were evaluated, as planned, and the experimental results are tabulated in Table 11-2.

All four candidate metals were subjected to pressure and vacuum tests after each of three heat/cooldown cycles. All indicated excellent sealing capabilities, no air leakage, and the metal was solidified when subjected to 5 in. of $\mathrm{H}_{2} \mathrm{O}$ pressure and $20 \mathrm{in}$. of $\mathrm{H}_{2} \mathrm{O}$ vacuum. 
TABLE 11-2. Metal Seal Test Observations

\begin{tabular}{|c|c|c|c|c|}
\hline Observation & $\begin{array}{l}\text { Metal Specialties } \\
\text { Alloy } 158-190\end{array}$ & $\begin{array}{l}\text { Metal Specialties } \\
\text { Alloy } 255\end{array}$ & $\begin{array}{c}\text { Lipowitz } \\
12505\end{array}$ & $\begin{array}{c}\text { Woods Metal } \\
158-165\end{array}$ \\
\hline $\begin{array}{l}\text { Metal Melting } \\
\text { Temperature - }{ }^{\circ} \mathrm{C}\end{array}$ & & $2=$ & & \\
\hline After 1 Cycle & $74,78-83$ & $135,128,125,124$ & $76,71,81$ & $71-78-81$ \\
\hline After 2 Cycles & $165,172-181$ & 275,255 & & 70,172 \\
\hline $\begin{array}{l}\text { Metal loss after } \\
3 \text { Cycles }\end{array}$ & $\begin{array}{l}\text { Initial }=3001.7 \mathrm{~g} \\
\text { Loss }=15.6 \mathrm{~g}\end{array}$ & $\begin{array}{l}\text { Initial }=3867 \mathrm{~g} \\
\text { Loss }=18.3 \mathrm{~g}\end{array}$ & $\begin{array}{l}\text { Initial }=2563.8 \mathrm{~g} \\
\text { Loss }=3.8 \mathrm{~g}\end{array}$ & $\begin{array}{l}\text { Initial }=2741.2 \mathrm{~g} \\
\text { Loss }=14.7 \mathrm{~g}\end{array}$ \\
\hline $\begin{array}{l}\text { Stainless steel } \\
\text { beaker diameter } \\
\text { distortion after } \\
\text { three cycles } \\
\text { (f3.4 in. dia) }\end{array}$ & $<10 \mathrm{mils}$ & $<6 \mathrm{mils}$ & $<10 \mathrm{mila}$ & $<5 \mathrm{mils}$ \\
\hline $\begin{array}{l}\text { Air inleakage } \\
\text { rate through } \\
\text { tube at } 20 \text { in. } \\
\mathrm{H}_{2} \mathrm{O} \text { vacuum }\end{array}$ & tit & 0 & $x^{2}$ & 0 \\
\hline $\begin{array}{l}\text { Air flow through } \\
\text { tube at } 5 \text { in. } \\
\mathrm{H}_{2}{ }^{\mathrm{O}} \text { pressure }\end{array}$ & 0 & 0 & 0 & 0 \\
\hline $\begin{array}{l}\text { Tendency of metal } \\
\text { to separate } \\
\text { from beaker } \\
\text { wall after } \\
\text { impact test }\end{array}$ & $\begin{array}{l}\text { No apparent ten- } \\
\text { dency fat metal } \\
\text { to separate from } \\
\text { mell }\end{array}$ & & & $\begin{array}{l}\text { No apparent ten- } \\
\text { dency for metal } \\
\text { to separate from } \\
\text { wall }\end{array}$ \\
\hline
\end{tabular}

The melting point of the Lipowitz 158 metal and the alloy \#255 metal was $-10 \%$ higher during each heat cycle than indicated by vendor. The measured melting points of the $158-190^{\circ} \mathrm{F}$ metal $\left(68-88^{\circ} \mathrm{C}\right)$ woods metal $158-165^{\circ} \mathrm{F}(68-$ $77^{\circ} \mathrm{C}$ ) were within the suggested melt range.

The number which identifies the metals is the suggested vendor melt temperature in ${ }^{\circ} \mathrm{F}$.

Each test apparatus with its associated metal was held at $-200^{\circ} \mathrm{C}$ for seven days to determine any weight loss or phase separation. Other visual observations were made which might not have become apparent during the short melt determination tests. 
During this portion of the test, visual observations were made to determine any off-gasing effects and none were noted. During the first test of each metal, an oxidized surface was formed. There was no apparent increase in this oxide layer during the remaining tests. No surface turbulence was observed during any of the heat cycles.

Prior to testing, each test apparatus was ultrasonically scanned in four locations to determine a base wall thickness. After the final test, each assembly was again subjected to the same ultrasonic scan. The sound velocity of the SS beaker and metal composition were too similar to allow sufficient signal attenuation to reasonably assure any change in beaker wall thickness. Upon cutting the test assemblies in half and visually observing the beaker wall subjected to the molten metal, no indication of corrosion attack was evident.

The major concern which prompted this investigation was the possible expansion effects of the metal on its container when it solidifies. The analogy is that of water freezing in a glass beaker and fracturing the glass upon freezing. Beaker diameter measurements were taken prior to and after each heat/cooling cycle. While minor ( $-10 \mathrm{~mL})$ changes were noted, no pattern was noted in the area of solidified metal versus the area above the metal. The wall thickness of the SS beaker being $-25 \mathrm{~mL}$ would exhibit far less capabilities to withstand this effect than material with a greater wall thickness. The actual surface layer of exposed metal would also have an important effect upon the relief of expansion rate as compared to metal in an enclosed system.

\subsection{CONCLUSIONS}

- Any one of the metals tested can be used as meltable metal seals.

- Alloy \#255 can be melted by high pressure steam coils and would be suitable in the temperature conditions anticipated in LFCM operations

- Alloy \#255 will form a solid seal under normal operating temperature conditions. 


\subsection{RECOMMENDATIONS}

1. It is recommended that selected liquid metals be tested in a closed system under operating conditions.

2. It is recommended that long-term tests be made to determine corrosion of metal containers, oxidation of metal over an extended period, and ability of metal to maintain seal over several make/break cycles.

3. It is recommended that seals be evaluated for ability to maintain their integrity under stressed or distortion conditions. 
$=$

:

. 


\section{APPENDIX A - DETAILED RESULTS OF MELTER DISCHARGE SECTION TESTING}

\section{A.1 DISCHARGE LID REMOTABILITY}

The prototype discharge lid was remotely installed on and removed from the mock melter shell five times using crane-only techniques. Figure A-1 shows a prototype test lid installed on a mock melter shell with an impact wrench being remotely lowered onto a nut. Figures A-2 through A-5 show the lid installation process.

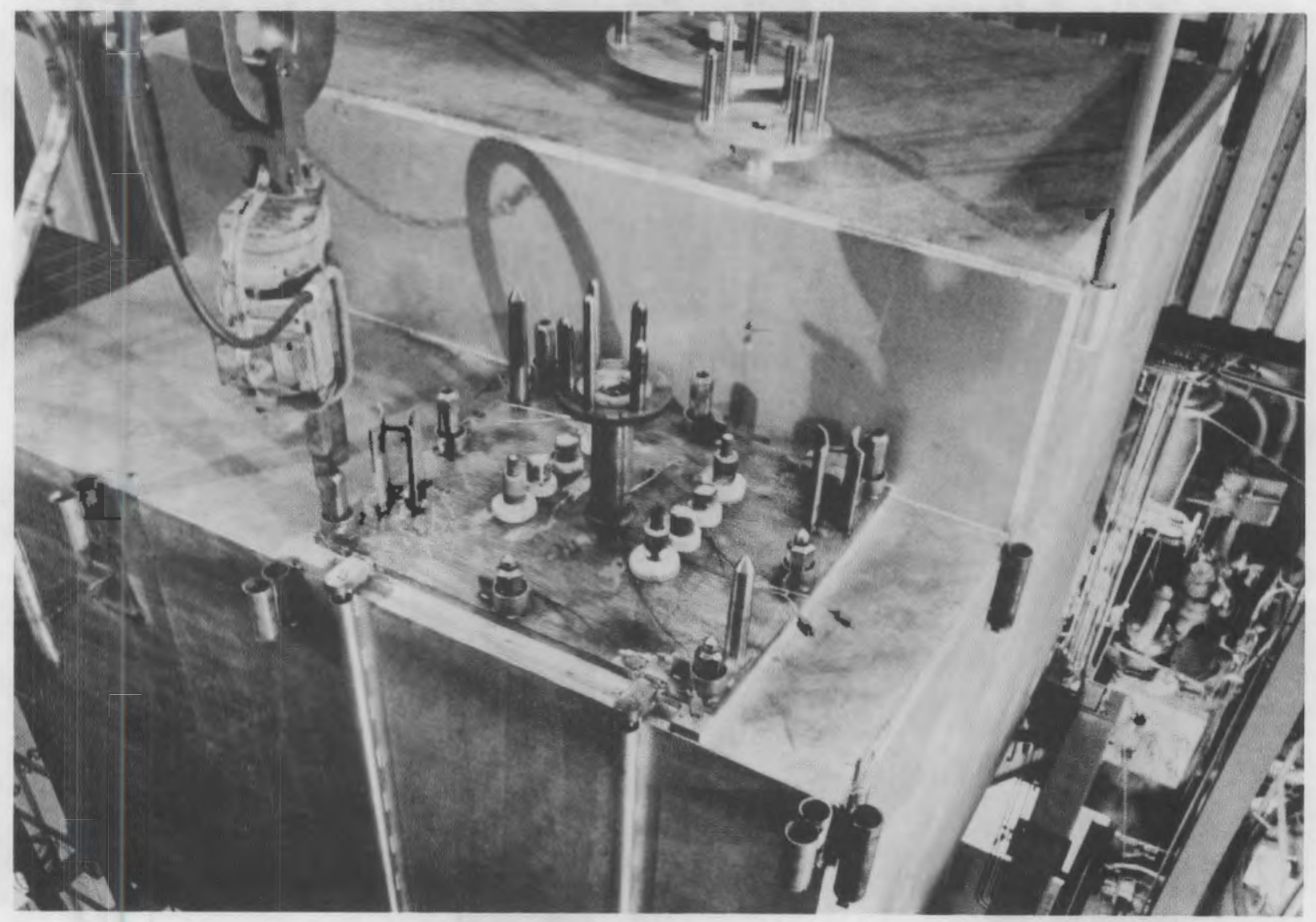

FIGURE A-1. Discharge Section Lid Installed on Melter Shell 


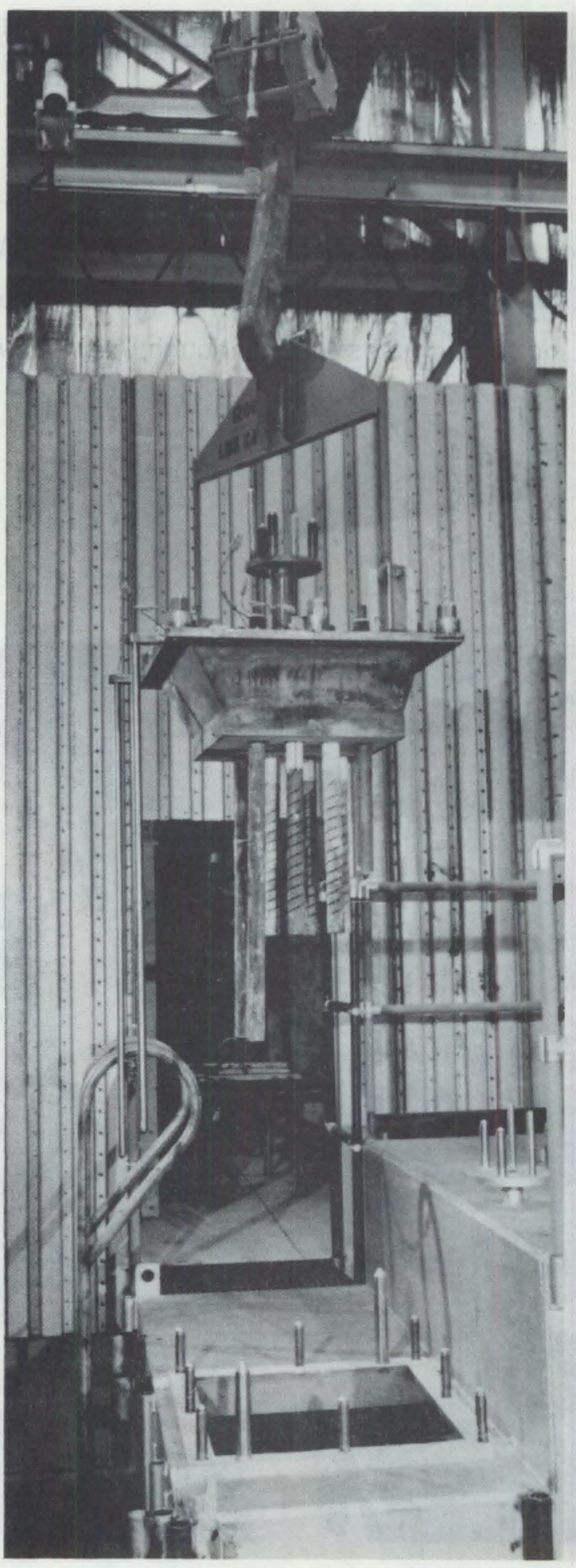

FIGURE A-2. The Lid is Positioned Above the Melter by Remote Control

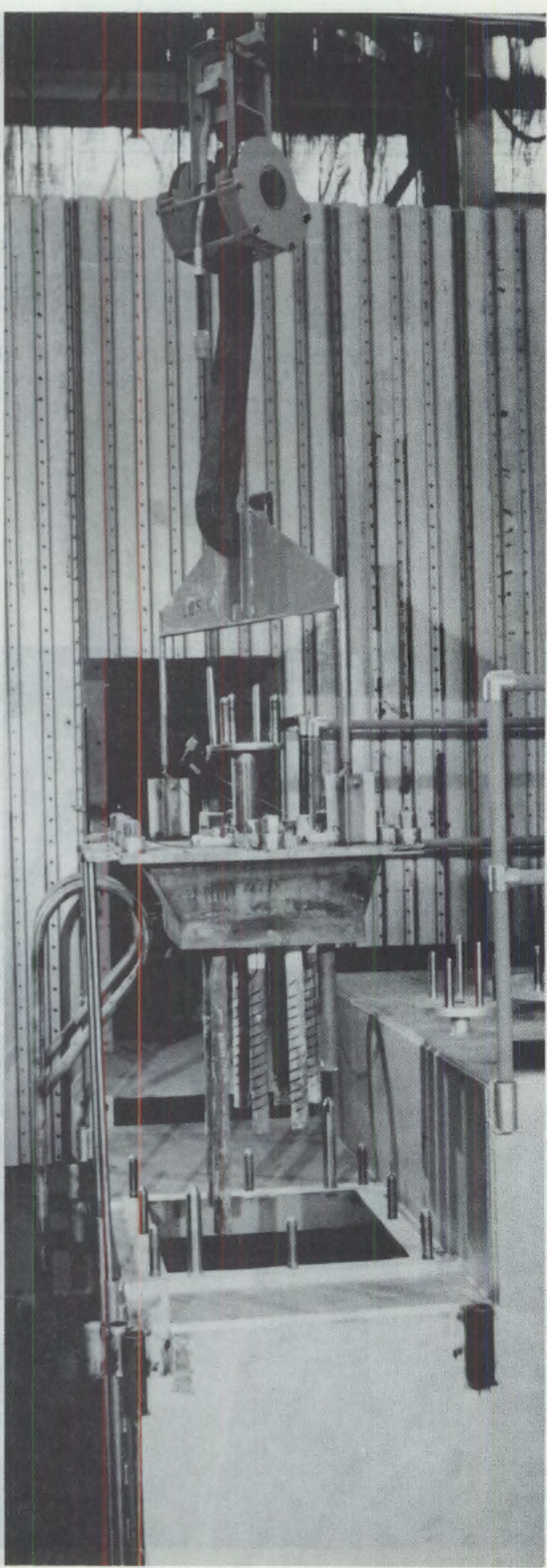

Figure A-3. Dowel Ends from Lid are Inserted in Guide Tubes on Melter 


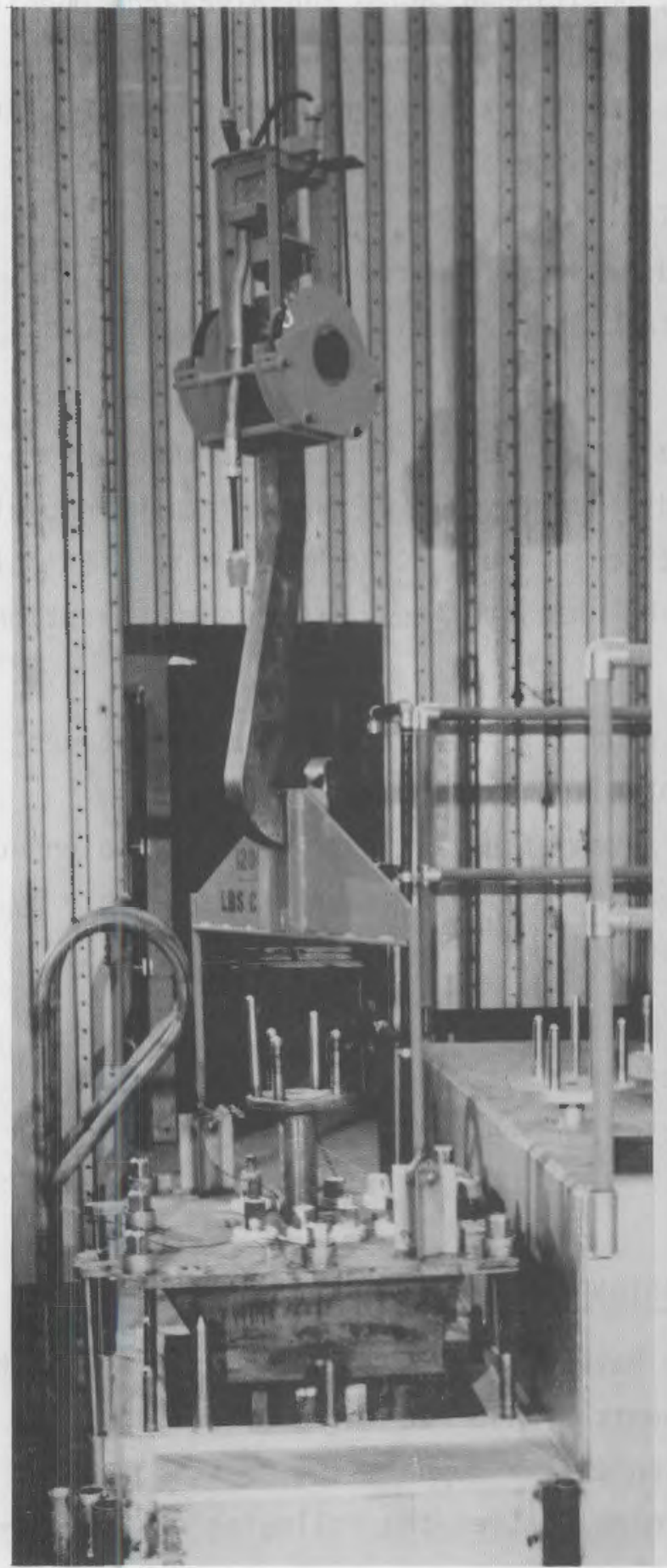

FIGURE A-4. Guide Dowels on Melter Flange are Lined up with Receiving Holes on Lid

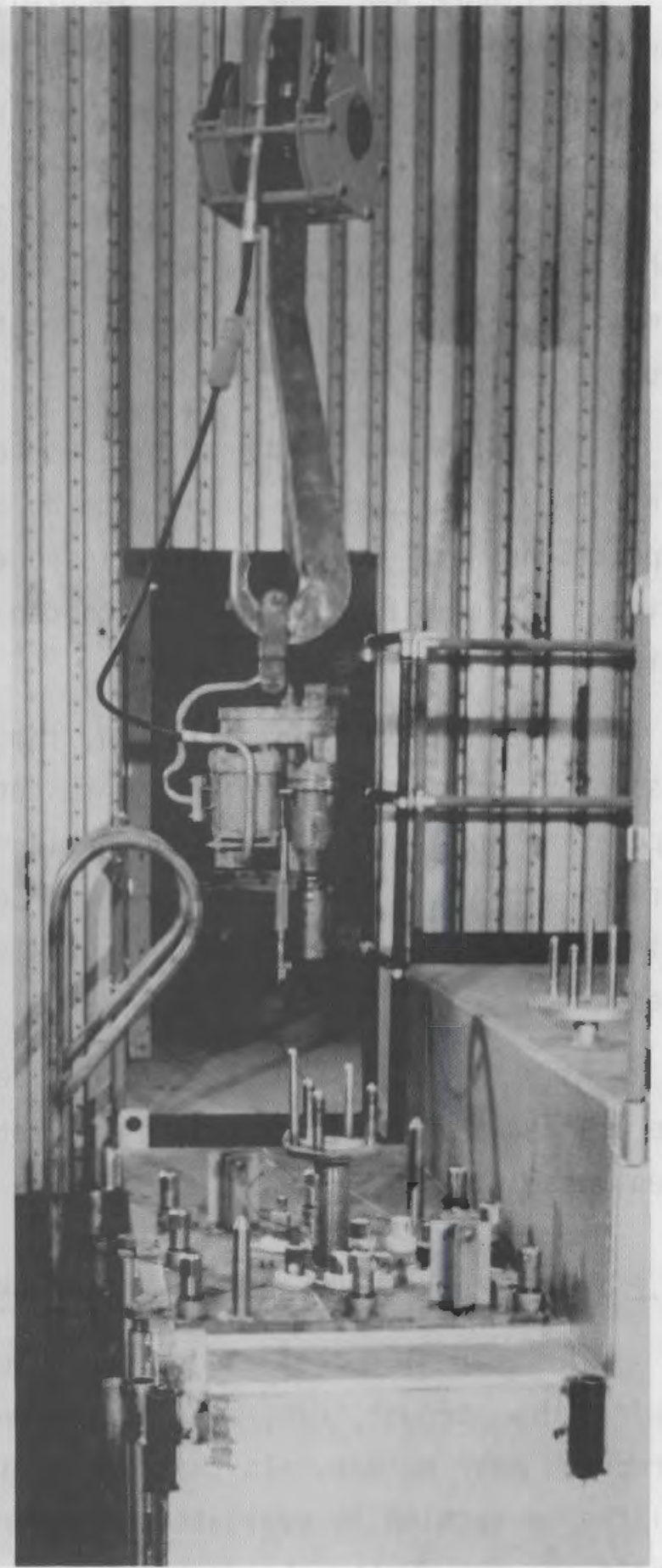

FIGURE A-5. Lid is in Place on Melter and the Impact Wrench is Being Lowered to Tighten Nuts, which Completes Installation 
In Figure $\mathrm{A}-2$, the lid is remotely positioned above the discharge opening on the melter shell. In Figure $\mathrm{A}-3$, the ends of the long guide dowels have been inserted in the guide tubes located on the side of the melter shell. In Figure $A-4$, the lid is lowered further into the discharge opening guided by the two dowels on the melter flange. The lid is near the shortest dowel in the foreground. In Figure A-5, the lid has been lowered into place and an impact wrench is being lowered by remote control to tighten the eight nuts, completing lid installation.

The first two discharge lid remote installation/removal operations were performed with direct viewing with no difficulty. Three installation/removal operations were performed with closed circuit viewing, again with no difficulties. The remote lid installation can be characterized as a smooth operation with or without direct viewing.

As part of each installation, the eight lid remote nuts were tightened using an impact wrench under remote control. Neither the lid-lowering operation nor impact-wrench ratcheting (even after 1 min or more of prolonged wrench vibration) was found to cause heating element damage as detectable by element-resistance measurements. Resistance measurement sensitivity was better than $\pm 0.001 \Omega$.

As a result of remote operation testing, the discharge lid was found to be well suited to both remote installation and removal, and is thus remotely replaceable.

\section{A.2 EVALUATION OF DISCHARGE SECTION DESIGN AND HEAT TRANSFER}

The thermal mockup was designed to have, from a heat transfer standpoint, refractory, trough, dam, and lid components similar to those planned on the proposed HWV melter. In this subsection of the report, the design of the discharge section is evaluated to determine whether the following design criteria are met during steady-state operation:

- trough and pour spout temperatures at $1000^{\circ} \mathrm{C}$ or above

- dam temperatures cool enough to prevent glass migration 
- discharge exterior wall, floor, and 1 id temperatures at $200^{\circ} \mathrm{C}$ or lower.

Related to this, the steady-state operating conditions and parameters associated with these criteria are estimated based on test data obtained using the discharge thermal mockup. Simplifying assumptions are listed, where used, and analyzed, where possible, with regard to validity. The test data used are for the case with dam cooling air flow rate at $8.1 \mathrm{scfm}$, inleakage flow rate at zero (mockup at atmosphere pressure), simulated turntable-to-discharge section inleakage at zero (airtight bellow seal), and steam coil off (cold canister not present). The effect of the variation of the above-listed parameters on discharge temperatures is discussed in Subsections A.3, A.4 and A.6. The effect on discharge temperatures of heating element failure is discussed in A.5.

During steady-state operation, the discharge section internal temperatures are as shown in Figure A-6, which also indicates the element power distribution. Note that element $\# 7$ was not operating and that element \#8 is operating at $\sim 1 \mathrm{~kW}$, so that most of the heat is distributed from behind the pour spout. At a total lid power level of $22.57 \mathrm{~kW}$, trough discharge temperatures are all above $1000^{\circ} \mathrm{C}$, with an average pour spout temperature of $1021^{\circ} \mathrm{C}$, an average glass path temperature of $1069^{\circ} \mathrm{C}$, and interior air temperatures up to $1097^{\circ} \mathrm{C}$. The dam centerline temperatures are as shown with an average air temperature, found to be relatively independent of dam air flow from $4 \mathrm{cfm}$ to $20 \mathrm{cfm}$, of $260^{\circ} \mathrm{C}$. The cooled edges of the dam are thus cold enough (below $\left.650^{\circ} \mathrm{C}\right)$ to stop the migration of glass.

Figure A-7 is a summary of simple energy balances performed on the discharge mockup for various dam cooling flow rates. For each case, the total input power from the lid elements, the heat loss due to dam cooling, and the remainder, considered as wall losses, are given based on the test data. As can be seen, the wall losses at fairly constant plenum and plate temperatures (first four cases) are $22.4 \mathrm{~kW} \pm 0.3 \mathrm{~kW}$. The total input power required to maintain internal discharge temperatures depends on dam cooling and ranges from about $20 \mathrm{~kW}$ to $30 \mathrm{~kW}$, depending on the extent of cooling. As can be 

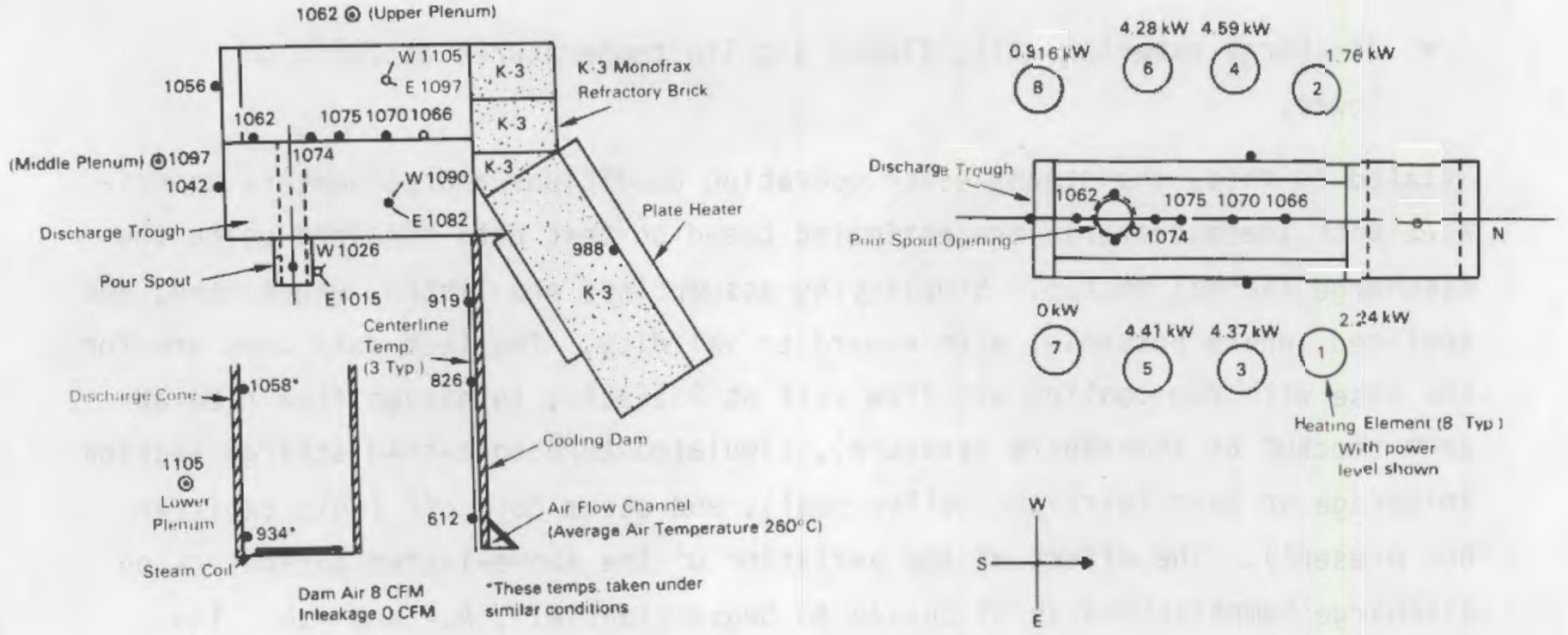

FIGURE A-6. Internal Temperature During Steady State Operation

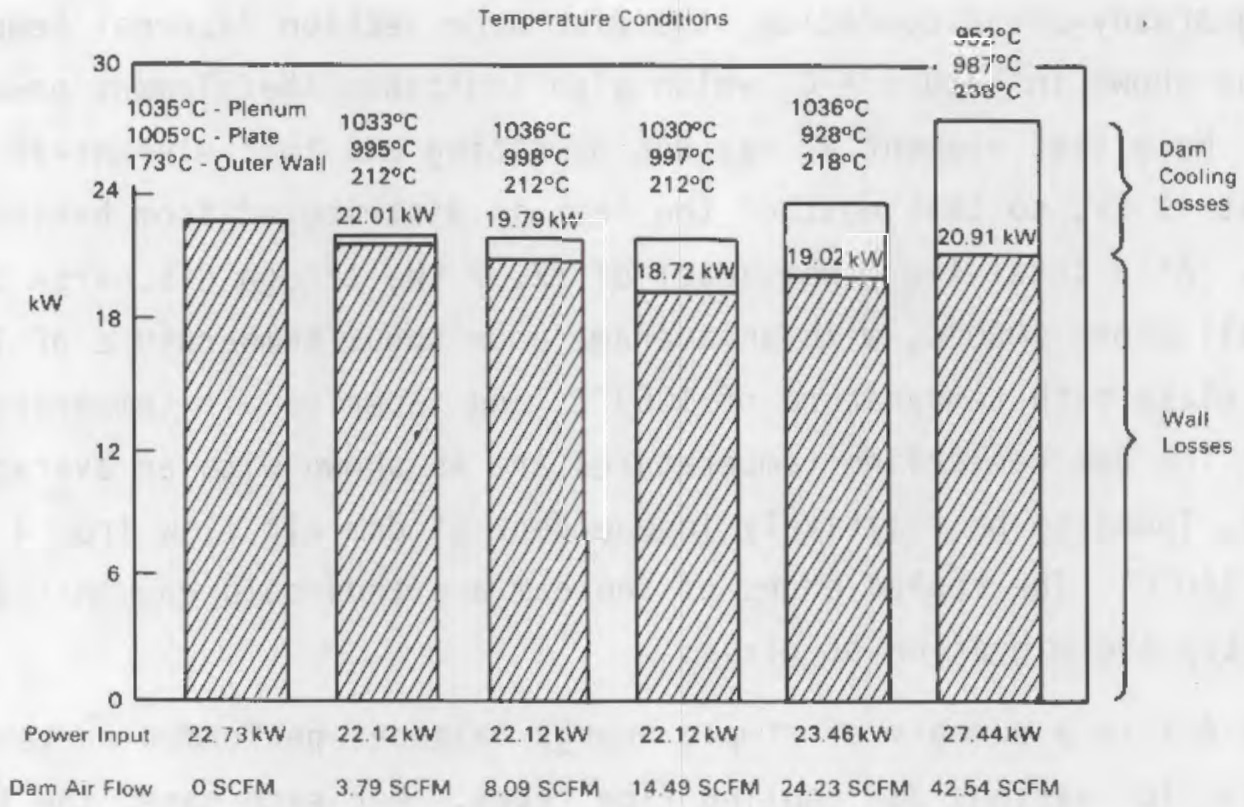

FIGURE A-7. Discharge Mockup Energy Balances at Various Dam Flow Rates

seen, the exterior wall temperatures range from $27^{\circ} \mathrm{C}$ below to $38^{\circ} \mathrm{C}$ above the $200^{\circ} \mathrm{C}$ maximum exterior temperature requirement with an average exterior temperature of $200^{\circ} \mathrm{C}$. How the values of heat input requirements and wall 
temperatures observed in the discharge thermal mockup correspond to those of the proposed HWV melter is predicted next.

An estimate of the heat input requirement for the HWV discharge section, as currently planned can be determined by calculating heat losses in the HWVP discharge section based on the thermal mockup test data. Refer to Figures A-8 and $A-9$, respectively.

In order to simplify the calculations, conductive heat transfer was assumed to be one dimensional, perpendicular to the inner-wall surface, and convective heat transfer from the external walls was assumed to occur only from an area equivalent to the internal wall area. Losses through the canister port were assumed to be equivalent to those that would occur through a 1/2-in. SS plate of the same size as the port. It was also assumed that there was no heat transfer from the discharge section to the melting cavity or vice versa. Plenum temperature was $1100^{\circ} \mathrm{C}$ for both melters. Ambient environment temperatures were considered to be $50^{\circ} \mathrm{C}$ and $20^{\circ} \mathrm{C}$ for the HWVP discharge section and thermal mockup, respectively. Finally, it was assumed that the HWVP melter will have two discharge sections separated by an adiabatic wall.

To predict heat losses in an actual discharge section, similarity relations were used with the thermal mockup test data. The similarity relations allow the dimensional differences between the thermal mockup and the planned discharge section to be accounted for. The dimensionless similarity relation for heat transfer from a hot environment to a cold environment through a wall is:

$$
\frac{Q}{U_{0} A \Delta T}=1
$$

where:

$\mathbf{Q}=$ energy loss

$U_{0}=$ overall heat transfer coefficient

$A=$ area of heat transfer surface

$\Delta \mathbf{T}=$ temperature difference between hot and cold environments. 
The boldface parameters are ratios of thermal mockup values to HWV discharge section values. In this calculation, primed quantities refer to thermal mockup values, while unprimed quantities indicate HWVP discharge section values. In the above equation:

$$
Q=\frac{Q^{\prime}}{Q}, \quad U_{0}=\frac{U_{0}^{\prime}}{U_{0}}, \quad A=\frac{A^{\prime}}{A}, \Delta T=\frac{\Delta T^{\prime}}{\Delta T}
$$

From the information presented in Figures $A-8$ and $A-9$, the thermal mockup test data and calculations of $U_{0}$ based on the figures, calculated values, and data are shown in Table A-1. From the test data, the energy loss distribution was calculated as shown in Table A-2, which also shows the predicted energy loss distribution for the HWVP discharge section.

From the information in Table A-2, the total power requirements for an HWVP discharge section will be $33.85 \mathrm{~kW}$, with $27.82 \mathrm{~kW}$ lost through conduction out of the refractory walls, $1 \mathrm{id}$, and floor, $3.40 \mathrm{~kW}$ lost through conduction to the air-cooled glass dam with an air flow of $14.5 \mathrm{scfm}$, and a $2.16 \mathrm{~kW}$ loss due to direct cooling caused by air inleakage through the lid and turntable at a combined flow of $11.5 \mathrm{scfm}$.

\section{A.3 AIR COOLED DAM PERFORMANCE}

The air dam is constructed of $1 / 4 \mathrm{in}$. SS with a U-shaped right-triangular duct having 2.5-in. sides and an interior duct cross section of 3.125 sq in. Figure A-10 is a sketch of the dam showing thermocouple locations. The dam, plenum, and plate heat temperatures were monitored at various dam cooling air flow rates from $0 \mathrm{scfm}$ to $42.5 \mathrm{scfm}$ as summarized in Figure A-11.

To prevent glass migration, it is only important that the lower edge of the dam (below locations 15,16 , and 18) run below $650^{\circ} \mathrm{C}$. As can be seen, this criteria is met only at a flow of $24.2 \mathrm{scfm}$. However, since the plate heater temperatures were maintained too high at lower flows, it is probable that dam temperatures are sufficiently low at flows above $8 \mathrm{scfm}$. From the energy balances in Section 3.3.2, it can be seen that dam cooling heat losses become significant (above $10 \%$ of the total heat input) at 8 scfm and above. Therefore, it is recommended that $8-10 \mathrm{scfm}$ dam cooling air should be used. 

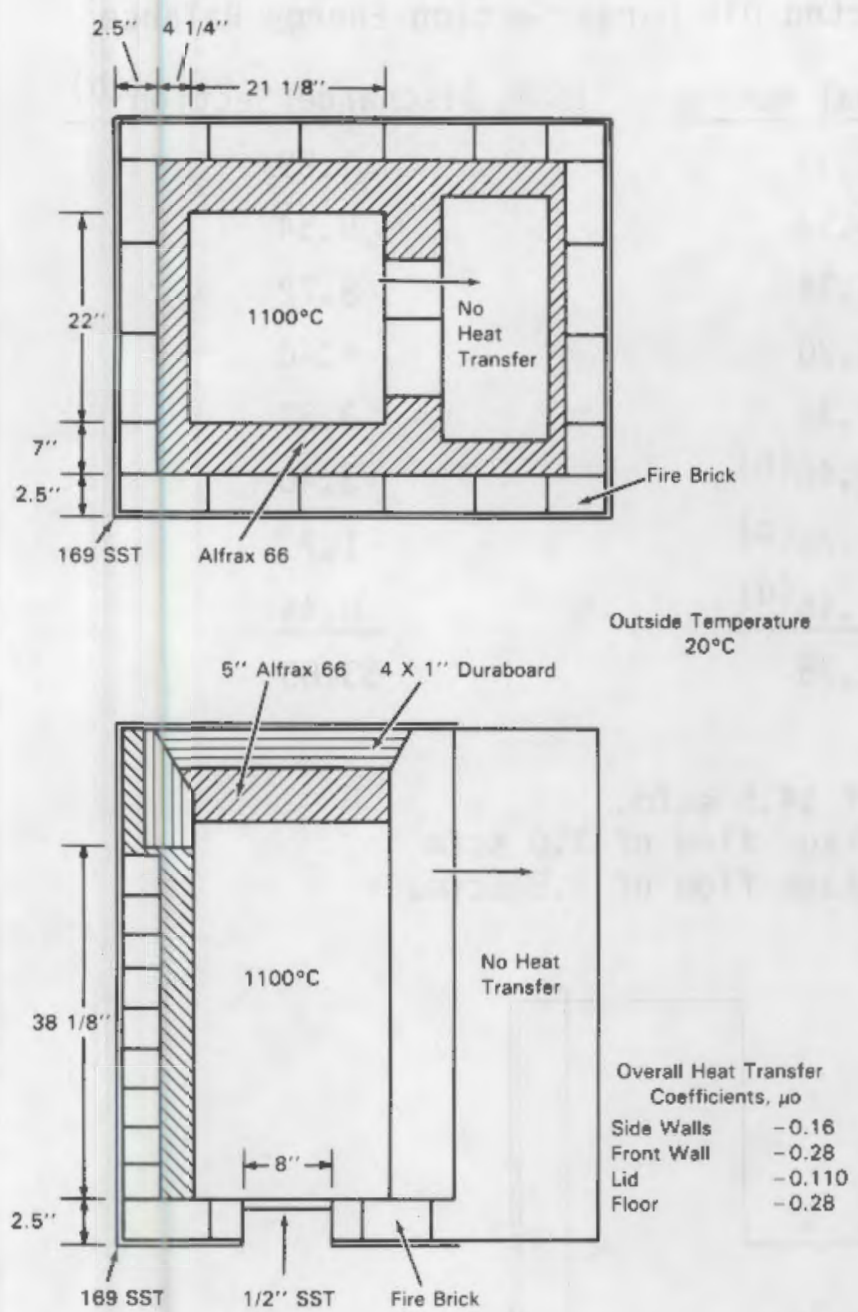

FIGURE A-8. HWVP Dimensions and Refactory Materials used for Heat Loss Calculations

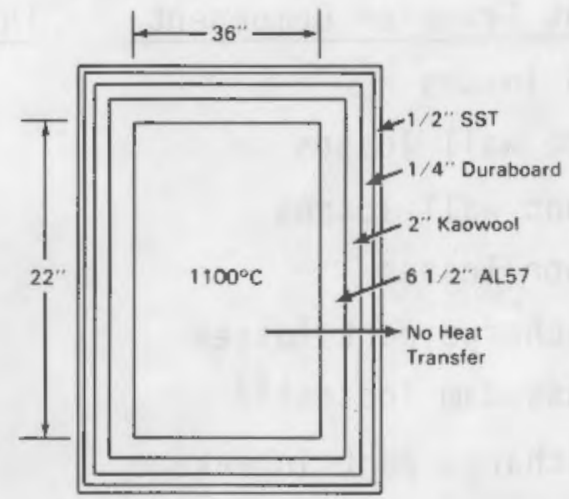

Outside Temperature

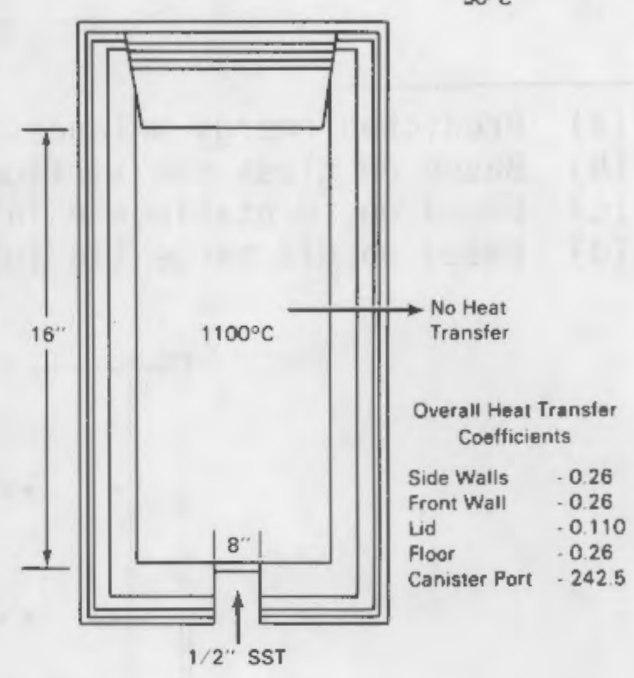

FIGURE A-9. TMU Dimensions and Refactory Materials used for Heat Loss Calculations

TABLE A-1. Thermal Mockup and HWVP Discharge Heat Transfer Quantities

Heat Transfer camponent

Lid

Side wall

Front wall

Floor

Port

\begin{tabular}{|c|c|c|c|c|c|c|c|c|c|}
\hline$U_{0}^{\prime}$ & $U_{0}$ & $u_{0}$ & $A^{\prime}$ & A & A & $\Delta \mathrm{T}^{\prime}$ & $\Delta \mathrm{T}$ & $\Delta T$ & $Q$ \\
\hline 0.11 & 01 & .00 & 3? & 5 & 0.582 & 16 & 1576 & 1.06 & 0.617 \\
\hline 0.16 & 0.26 & 0.615 & 11.2 & 7.03 & & 1672 & 1576 & 1.06 & 1.04 \\
\hline 0.28 & 0.26 & 1.08 & 5.8 & 11.5 & 0.5 & 1672 & 1576 & 1.06 & .56 \\
\hline 0.28 & 0.26 & 1.08 & 2.85 & 5.15 & 0.55 & 1672 & 1576 & 1.06 & 0.6 \\
\hline 2.5 & 242.5 & 1.00 & 0.35 & 0.35 & 1.00 & 12 & 10 & 1.2 & 1.2 \\
\hline
\end{tabular}


TABLE A-2. Calculated and Predicted Discharge Section Energy Balance

Heat Transfer Component Thermal Mockup HWVP Discharge Section (b)

Lid losses

1.37

6.93

6.34

3.20

2.38

$3.40^{(b)}$

$1.70^{(c)}$

$\frac{0.46^{(d)}}{25.78}$
1.89

9.54

8.72

4.40

3.27

3.40

1.7

0.46

(a) Predicted energy balance.

(b) Based on glass dam airflow of $14.5 \mathrm{scfm}$.

(c) Based on turntable air inleakage flow of $3.0 \mathrm{scfm}$.

(d) Based on discharge lid inleakage flow of $8.5 \mathrm{scfm}$.

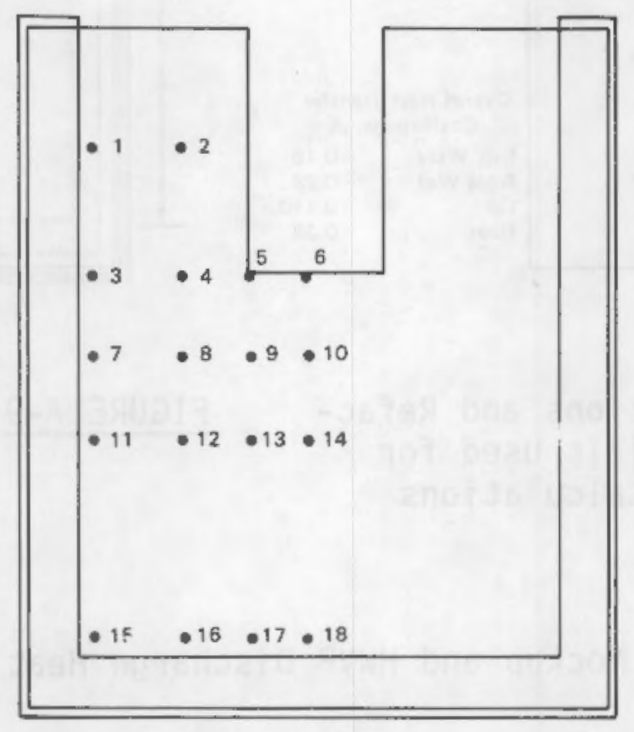

FIGURE A-10. Thermocouple Locations on Cooling Dam of Thermal Mockup Unit 


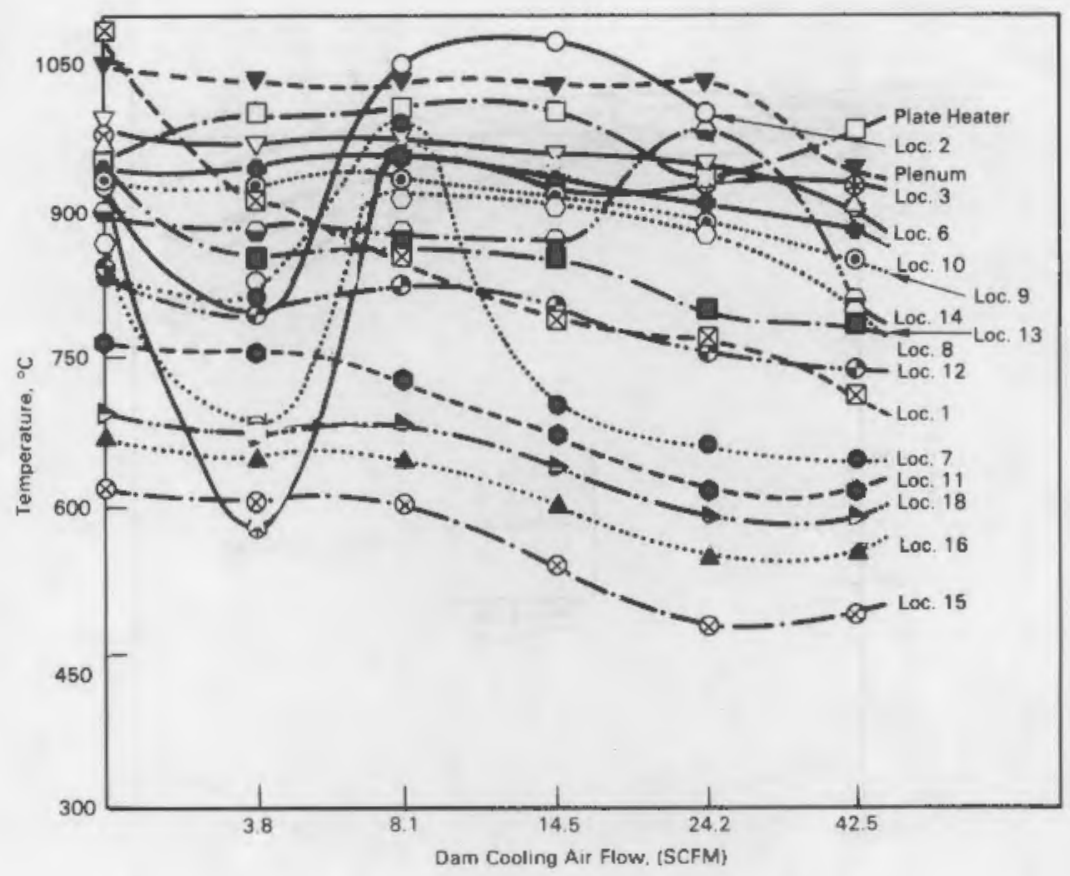

FIGURE A-11. Dam Temperatures Versus Dam Air Flow and Plenum Temperature

In addition, the average temperature within the duct will be $\sim 260^{\circ} \mathrm{C}$ so that the slanted duct exterior surfaces will be cooler than $650^{\circ} \mathrm{C}$ at these flow rates. The dam air outlet temperatures at $8.1 \mathrm{scfm}$ were measured between $450^{\circ} \mathrm{C}$ and $530^{\circ} \mathrm{C}$.

Except along the dam itself, there was no effect on internal discharge temperatures or variations in dam cooling air flow rate. At all air flow rates, the trough maintained a high enough temperature to keep glass molten. At a dam air flow rate of $52.5 \mathrm{scfm}$ and a plenum temperature of $1043^{\circ} \mathrm{C}$, the midplane of the trough had an average temperature of $1074^{\circ} \mathrm{C}$.

\section{A.4 EFFECT OF DISCHARGE SECTION INLEAKAGE ON TROUGH TEMPERATURES}

It was found that air leakage up into the discharge section from the turntable through the discharge cone has an effect on discharge trough temperatures. Figure $\mathrm{A}-12$ is a plot of the discharge trough pour spout and glass path temperatures as a function of simulated turntable inleakage calculated in scfm. Above an inleakage rate of $\sim 3.0 \mathrm{scfm}$, the discharge trough temperatures 


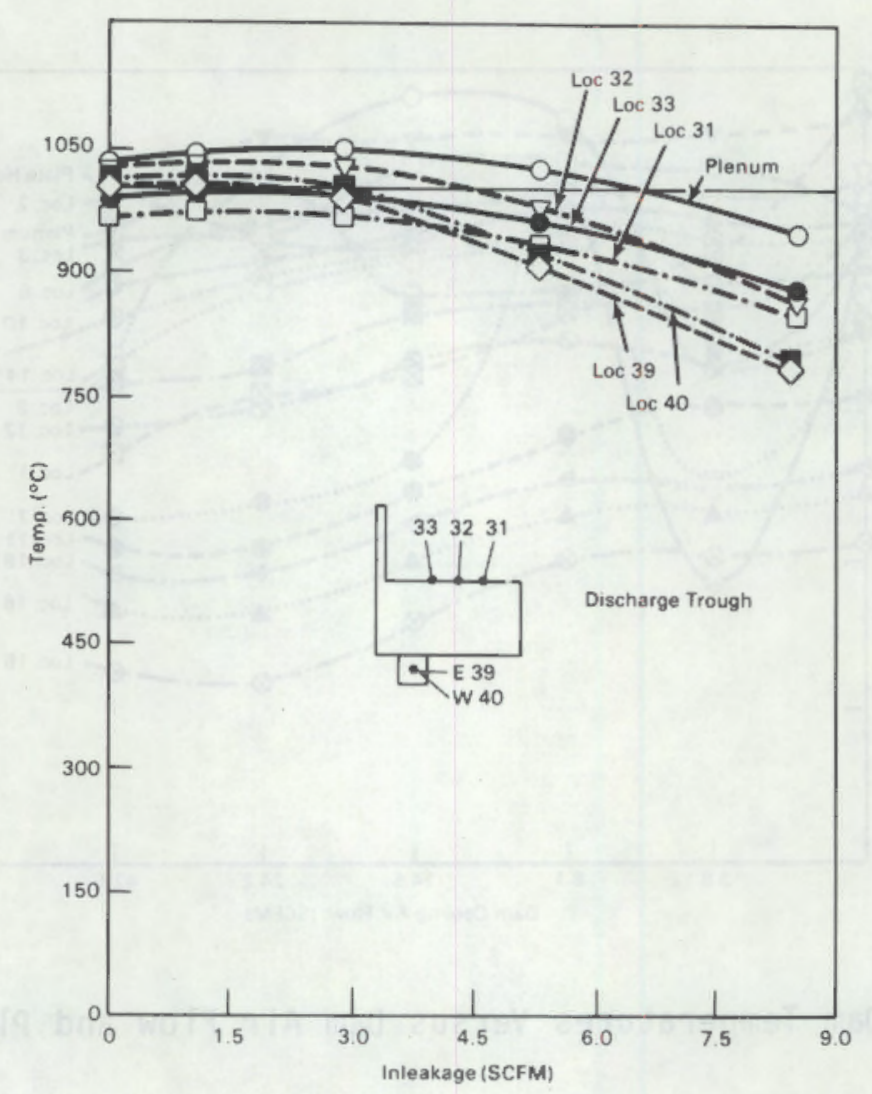

FIGURE A-12. Discharge Trough and Glass Path Temperatures as a Function of Air Inleakage

show a marked decline. Below $3.0 \mathrm{scfm}$, the trough pour spout was adequately above the $1000^{\circ} \mathrm{C}$ minimum operating temperature. However, increased air inleakage drops the pour spout temperatures below the minimum operating conditions.

An attempt was made to maintain pour spout temperatures above $1000^{\circ} \mathrm{C}$ at each inleakage rate by increasing the power level in the discharge section plenum. Figure A-13 is a histogram of the required power increase as a function of rate of air inleakage. As can be seen at $2.9 \mathrm{scfm}, 1.7 \mathrm{~kW}$ additional power is required.

During testing, the discharge mockup was operated with the off gas vented to the atmosphere. The rate of inleakage was measured, as well as the temperature of the exiting off gas. Using this data, the extent of discharge cooling caused by inleakage from the turntable can be estimated. For an 


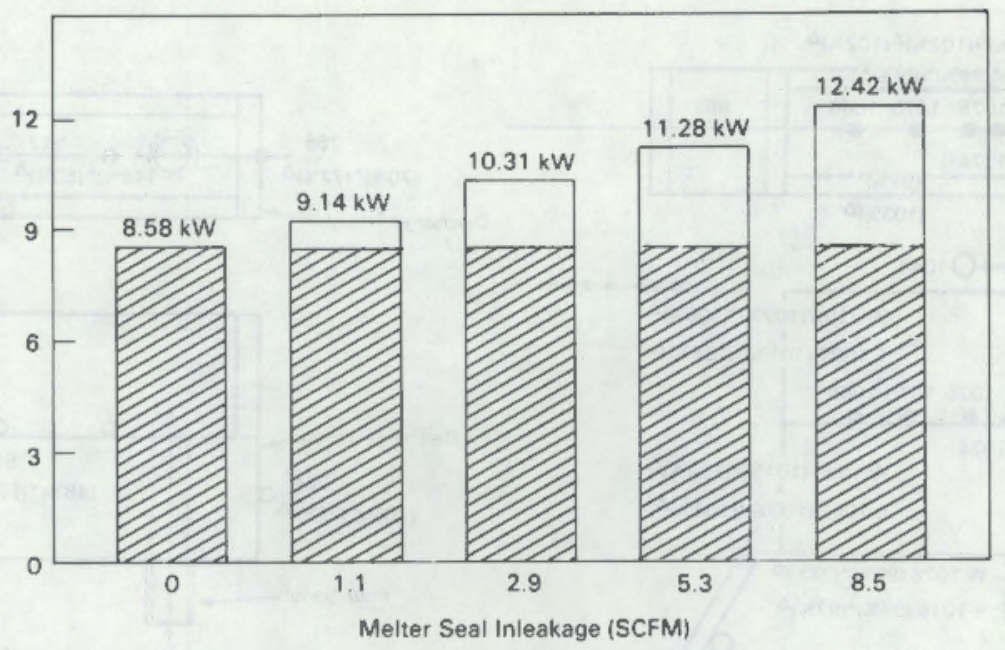

FIGURE A-13. Required Power Increase as a Function of Rate of Air Inleakage

inleakage rate of $8.5 \mathrm{scfm}$, off-gas temperature was measured as $206^{\circ} \mathrm{C}$, leading to a calculated discharge energy loss of $0.46 \mathrm{~kW}$. At a rate of $2.95 \mathrm{scfm}$, with off-gas temperature being $252^{\circ} \mathrm{C}$, the calculated discharge energy loss was $0.17 \mathrm{~kW}$.

\section{A.5 EFFECT OF HEATING ELEMENT FAILURE ON TROUGH TEMPERATURES}

The test data indicates that the loss of elements affects temperature profiles on the trough. During the testing, there was never a period when all eight lid elements worked correctly so that the reference case, as discussed in Section 3.3.2, has element \#7 off and element \#8 at $1 \mathrm{~kW}(1 \mathrm{ow})$. Figure A-14 shows trough temperatures expressed as percentage of middle and lower plenum temperatures for the reference case. As can be seen, even with \#7 out and \#8 at low power, trough temperatures are all sustained above the $1000^{\circ} \mathrm{C}$ minimum. In Figure A-15, element \#3 only is off and, as shown, trough temperatures are far below the $1000^{\circ} \mathrm{C}$ minimum even though the power level of the seven operational elements totals $26.2 \mathrm{~kW}, 3 \mathrm{~kW}$ higher than normal. Similar results are shown in Figure A-16 with element \#6 of $\mathrm{f}$. Trough temperatures are too low to sustain flow of glass even at a lid power level of $26.2 \mathrm{~kW}$. The data shows that loss of element \#6 is even worse than loss of \#3. Note that element \#5 is at about half power, contributing to the lowering of trough temperatures to $25 \%$ of plenum temperature. Lid power is at $26.62 \mathrm{~kW}$. In Figures A-17 and A-18, two middle elements are off; elements \#3 and \#4, and 


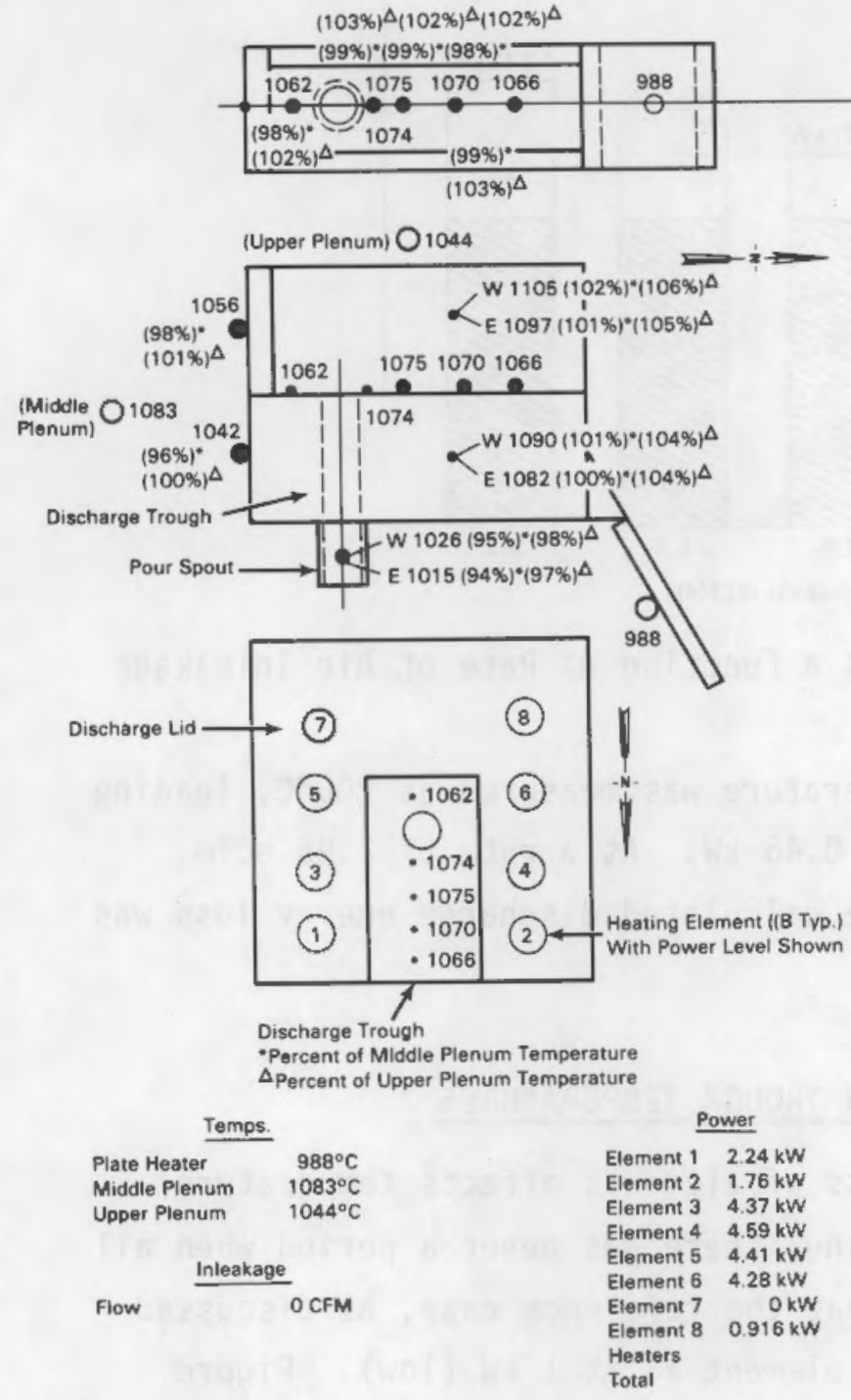

FIGURE A-14. Trough Temperatures for Reference Case
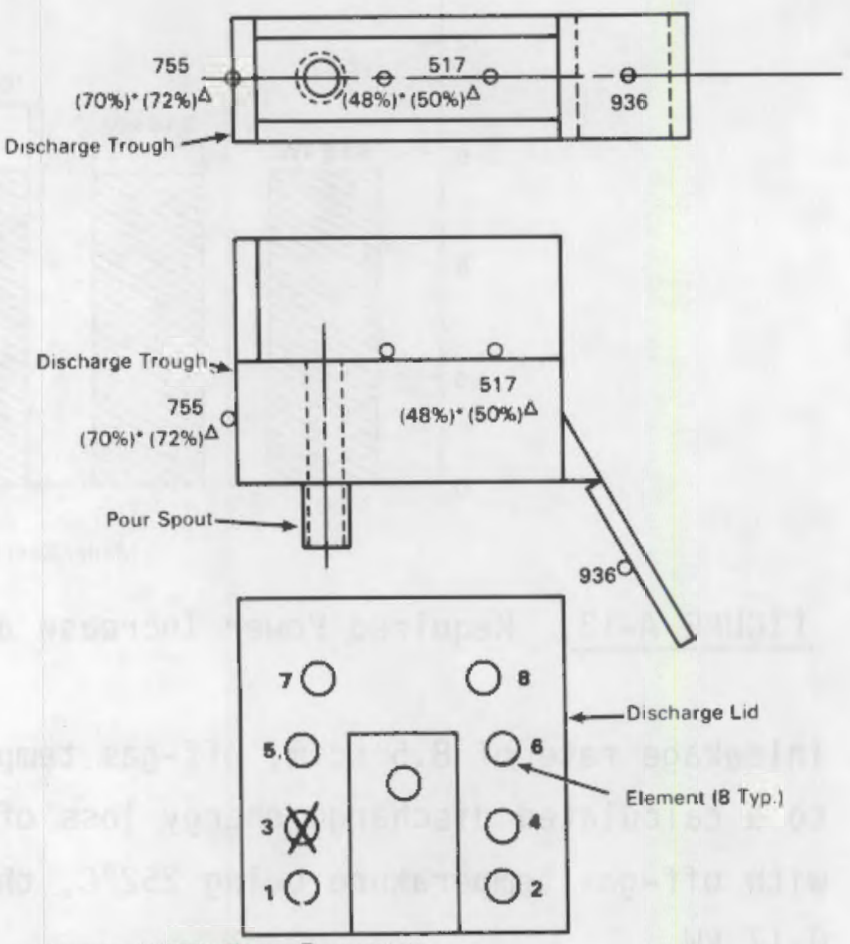

- Percent of Middle Plenum Temperature $\Delta$ Percent of Lower Plenum Temperature

Temps.

Middle Plenum $1078^{\circ} \mathrm{C}$

Lower Plenum $1043^{\circ} \mathrm{C}$

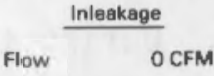

299:15:31:07

Power

10-26-83

FIGURE A-15. Trough Temperatures with Loss of Element \#3 

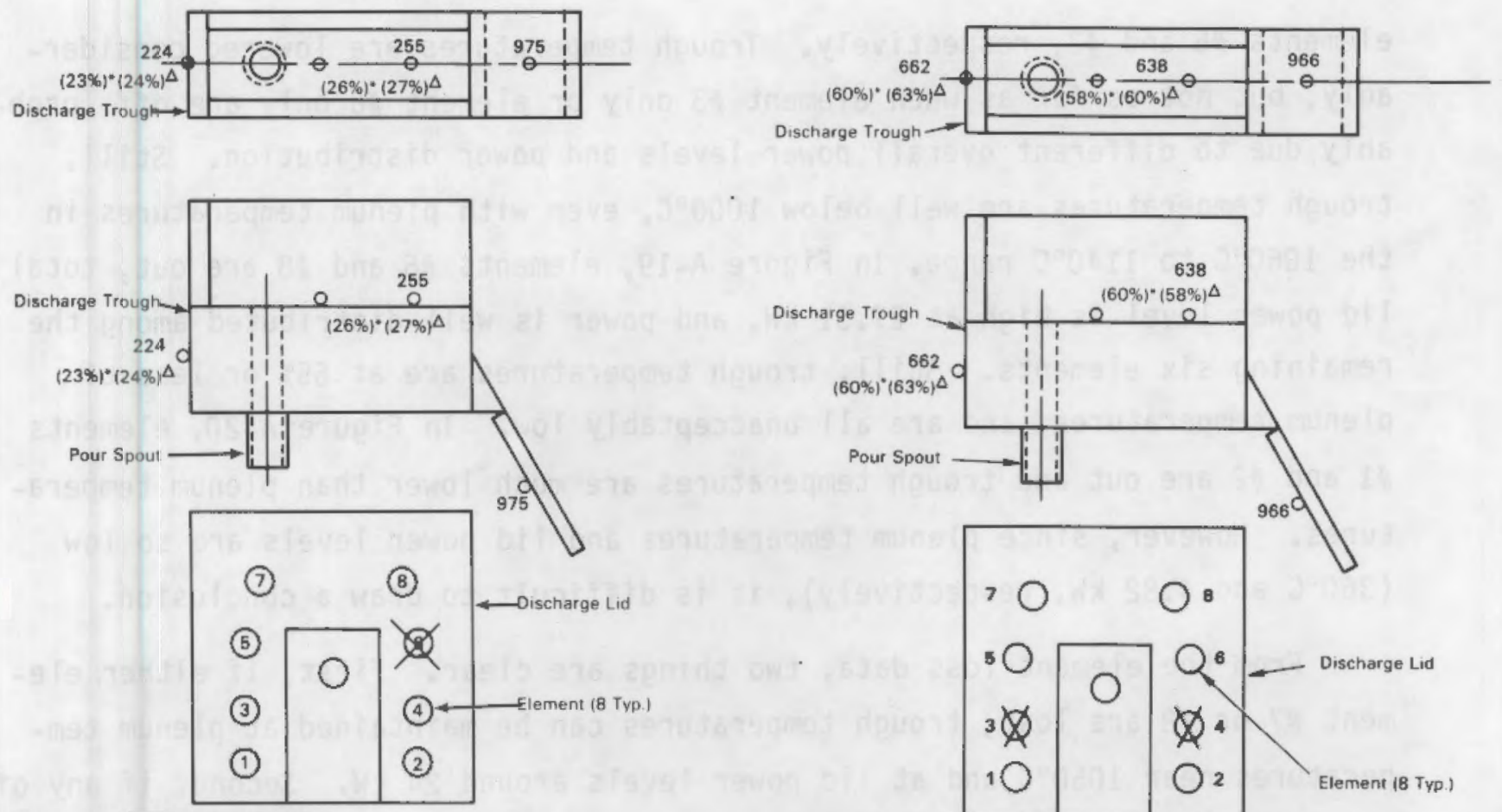

- Percent of Middle Plenum Temperature

$\Delta$ Percent of Lower Plenum Temperature

\begin{tabular}{|c|c|c|c|}
\hline \multicolumn{2}{|l|}{ Temps. } & \multicolumn{2}{|c|}{ Power } \\
\hline Plate Heater & $975^{\circ} \mathrm{C}$ & Element 1 & $2.09 \mathrm{~kW}$ \\
\hline Middle Plenum & $986^{\circ} \mathrm{C}$ & Element 2 & $1.80 \mathrm{~kW}$ \\
\hline Lower Plenum & $930^{\circ} \mathrm{C}$ & $\begin{array}{l}\text { Element } 4 \\
\text { Element } 5\end{array}$ & $5.65 \mathrm{~kW}$ \\
\hline Inleakage & & Element 6 & 0 \\
\hline Flow & O CFM & $\begin{array}{l}\text { Element } 7 \\
\text { Element } 8 \\
\text { Heaters }\end{array}$ & $\begin{array}{l}3.15 \mathrm{~kW} \\
3.35 \mathrm{~kW} \\
1.51 \mathrm{~kW}\end{array}$ \\
\hline $300: 11: 54: 30$ & & Total & $26.62 \mathrm{~kW}$ \\
\hline
\end{tabular}

10-27-83

\section{FIGURE A-16. Trough Temperatures with Loss of Element \#6}


elements \#5 and \#3, respectively. Trough temperatures are lowered considerably, but not as far as when element \#3 only or element \#6 only are off, probably due to different overall power levels and power distribution. Still, trough temperatures are well below $1000^{\circ} \mathrm{C}$, even with plenum temperatures in the $1060^{\circ} \mathrm{C}$ to $1140^{\circ} \mathrm{C}$ range. In Figure $\mathrm{A}-19$, elements $\# 6$ and $\# 8$ are out, total lid power level is high at $27.31 \mathrm{~kW}$, and power is well distributed among the remaining six elements. Still, trough temperatures are at $65 \%$ or less of plenum temperatures, and are all unacceptably low. In Figure A-20, elements \#1 and \#2 are out and trough temperatures are much lower than plenum temperatures. However, since plenum temperatures and lid power levels are so low $\left(360^{\circ} \mathrm{C}\right.$ and $4.82 \mathrm{~kW}$, respectively), it is difficult to draw a conclusion.

From the element loss data, two things are clear. First, if either element \#7 or \#8 are lost, trough temperatures can be maintained at plenum temperatures near $1050^{\circ} \mathrm{C}$ and at lid power levels around $24 \mathrm{~kW}$. Second, if any of the four middle elements are lost, plenum temperatures must be much higher than $1050^{\circ} \mathrm{C}$ to maintain trough temperatures above $1000^{\circ} \mathrm{C}$. From the data, it appears discharge plenum temperatures would have to be maintained at as high or higher than $2000^{\circ} \mathrm{C}$, requiring power levels far in excess of $30 \mathrm{~kW}$. It is not clear what the effect of losing elements \#1 or \#2 will be; however, the percentages in Figure A-20 suggests that the loss of both elements \#1 and \#2 is relatively small, and that maintaining plenum temperatures around $1100^{\circ} \mathrm{C}$ using the other six elements would be sufficient. This is due both to the relatively small power loading of elements \#1 and \#2 in the discharge mockup, and to the heating of the rear portion of the trough by the melting cavity.

Since the loss of any one of elements $\# 3, \# 4, \# 5$ or $\# 6$ will require excessive power levels on the remaining elements, it must be concluded and recommended that all lid elements be capable of running at as much as double or more their power, if required. 

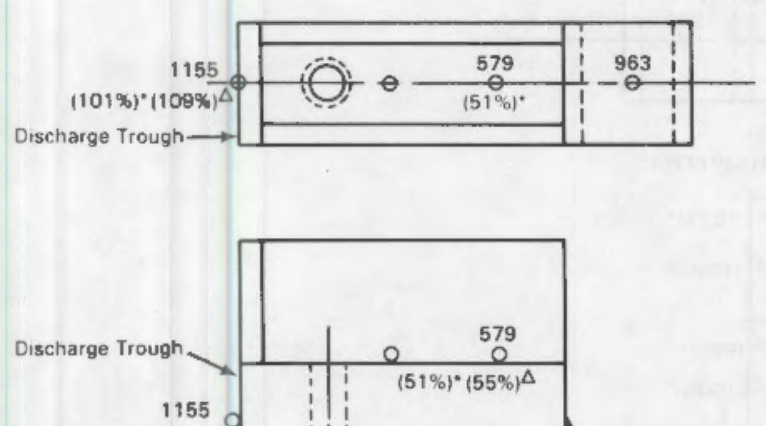
$(101 \%) *(109 \%)^{\Delta}$ Pour Spout
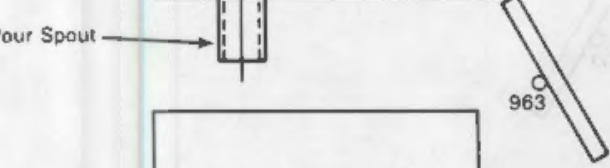

(7)

(B)

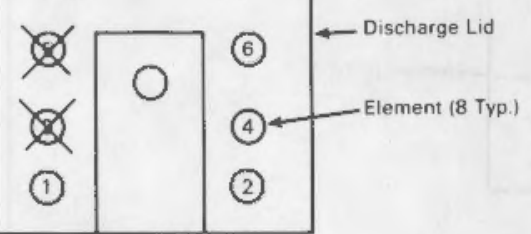

- Percent of Middle Plenum Temperature $\Delta$ Percent of Lower Plenum Temperature

$$
\text { Temps. }
$$

Plate Heater $963^{\circ} \mathrm{C}$

Middle Plenum $1139^{\circ} \mathrm{C}$

Lower Plenum $1060^{\circ} \mathrm{C}$

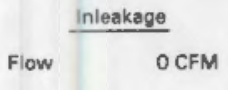

$300: 08: 08: 35$

10-27-83

\section{FIGURE A-18. Trough Temperatures with Loss of Elements $\# 3$ and \#5}
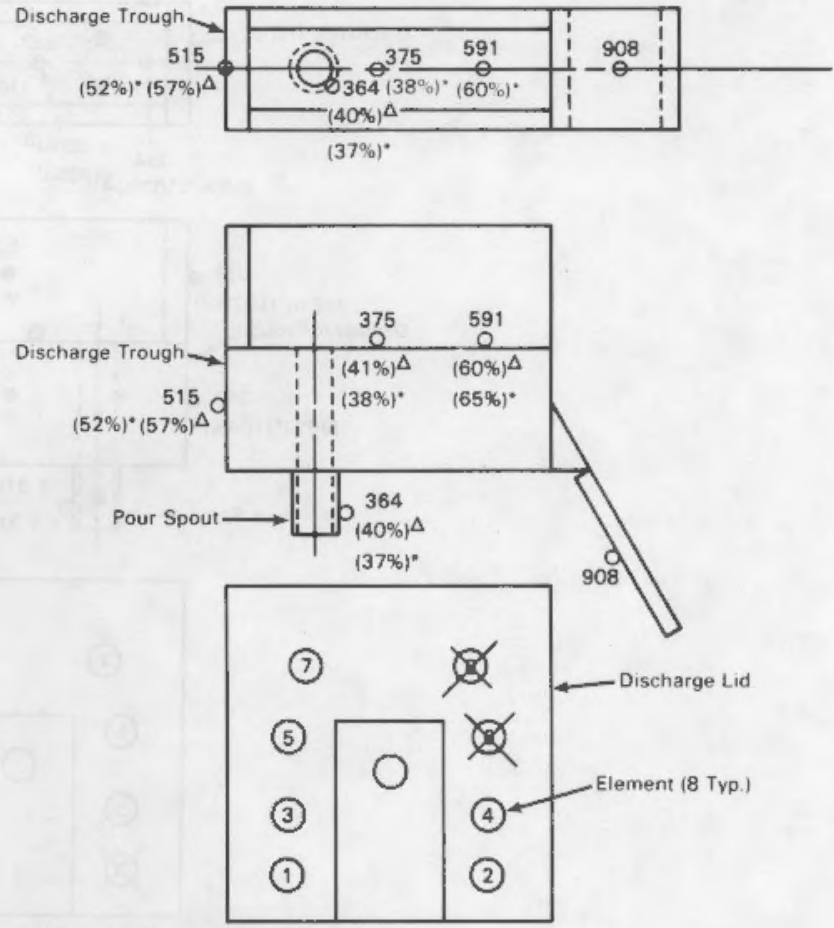

-Percent of Middle Plenum Temperature $\Delta$ Percent of Lower Plenum Temperature

Temps.

Power

\begin{tabular}{|c|c|c|c|c|}
\hline Plate I & Heater & $908^{\circ} \mathrm{C}$ & Element 1 & $3.33 \mathrm{~kW}$ \\
\hline Middle & e Plenum & $988^{\circ} \mathrm{C}$ & Element 2 & $2.85 \mathrm{~kW}$ \\
\hline & & & Element 3 & $4.62 \mathrm{~kW}$ \\
\hline Lower & Plenum & $907^{\circ} \mathrm{C}$ & Element 4 & $4.37 \mathrm{~kW}$ \\
\hline & & & Element 5 & $4.74 \mathrm{~kW}$ \\
\hline & Inleakag & & Element 6 & 0 \\
\hline & & & Element 7 & $6.06 \mathrm{~kW}$ \\
\hline Flow & & OCFM & $\begin{array}{l}\text { Element } 8 \\
\text { Heaters }\end{array}$ & $\begin{array}{c}0 \\
1.34 \mathrm{~kW}\end{array}$ \\
\hline$\infty$ & 9.43 & & Total & $27.31 \mathrm{~kW}$ \\
\hline
\end{tabular}

$10-27-83$

FIGURE A-19. Trough Temperatures with Loss of Elements \#6 and \#8 


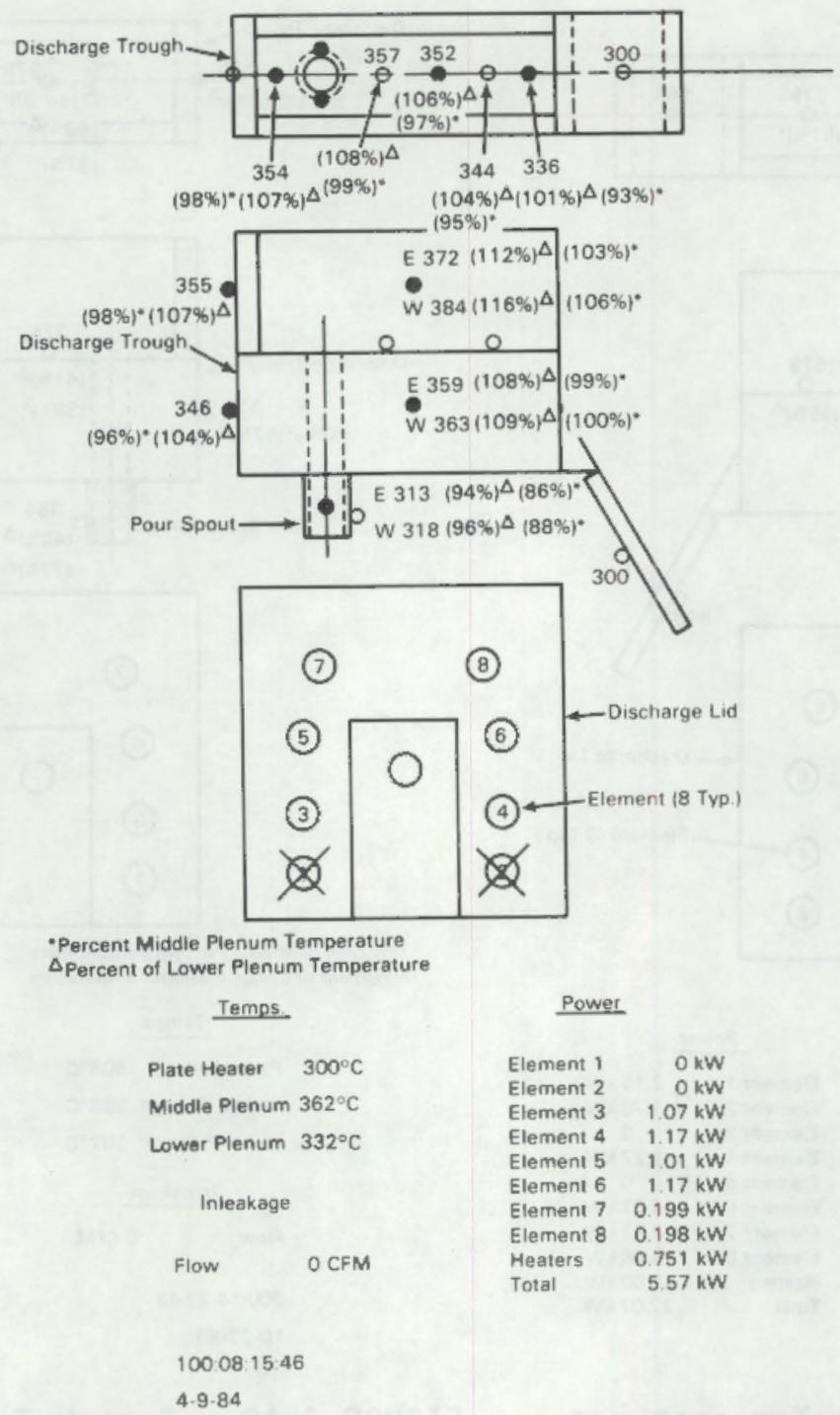

FIGURE A-20. Trough Temperatures with Loss of Elements \#1 and \#2

\section{A.6 EFFECT OF PRESENCE OF COLD CANISTER ON TROUGH TEMPERATURES}

A pancake-shaped steam coil with a steam inlet temperature of $162^{\circ} \mathrm{C}$ and an outlet at $330^{\circ} \mathrm{C}$ was used to simulate the presence of the bottom of a cold canister. Since only the bottom of a canister would receive direct radiant heat transfer (direct shine) from the pour spout, a cold disk located on the axis of the canister within the mock discharge cone provides an adequate simulation. From the test data, the steam coil at an average $246^{\circ} \mathrm{C}$ had no effect 
on the temperature of the pour spout or any other part of the trough. During the test, the pour spout was maintained at $1028^{\circ} \mathrm{C}$ with a standard plenum temperature of $1058^{\circ} \mathrm{C}$. A simple calculation can be done to show that canister bottom temperatures could not be low enough to lower the pour spout temperature below $1028^{\circ} \mathrm{C}$. Refer to Figure A-20. Assuming the distance from the canister bottom to a point in the middle of the discharge cone is $\sim 12 \mathrm{ft}$, the canister bottom would have to be $-1262^{\circ} \mathrm{C}$ to lower the pour spout temperature based on the test data.

\section{A.7 DISCHARGE LID HEATING ELEMENT PERFORMANCE}

Several tests were performed to aid in an evaluation of discharge lid heating element performance, including comparisons of the type of heating element, type of element contact surface, and type of electrical contact hardware.

First, heating element resistances were calculated based on input amperage and voltage data, and monitored as discharge temperatures were increased from $30^{\circ} \mathrm{C}$ to $1050^{\circ} \mathrm{C}$. The resistance values as a function of plenum temperature are presented in Table A-3 and plotted in Figure A-21. All elements contained their original, manufacturer-applied aluminum contact surface coating.

As can be seen, the coaxial elements have much lower overall resistance than spiral elements, making them more difficult than the spiral elements to control. The coaxial elements have the advantage of being more physically durable due to their rod-within-a-cylinder construction. However, it was found during testing that neither spiral nor coaxial elements had long electrical lifetimes.

\section{TABLE A-3. Heating Element Resistance Data}

\begin{tabular}{|c|c|c|c|c|c|c|c|c|}
\hline Element \# & Type & $100^{\circ} \mathrm{C}$ & $220^{\circ} \mathrm{C}$ & $300^{\circ} \mathrm{C}$ & $580^{\circ} \mathrm{C}$ & $800^{\circ} \mathrm{C}$ & $930^{\circ} \mathrm{C}$ & $1015^{\circ} \mathrm{C}$ \\
\hline 1 & Coaxial & 0.31 & 0.23 & 0.22 & 0.22 & 0.22 & 0.23 & 0.24 \\
\hline 2 & Coaxial & 0.29 & 0.22 & 0.20 & 0.20 & 0.21 & 0.21 & 0.21 \\
\hline 3 & Spiral & 2.8 & 2.8 & 2.6 & 2.5 & 2.6 & 2.7 & 2.8 \\
\hline 4 & Spiral & 2.9 & 2.9 & 2.6 & 2.5 & 2.7 & 2.8 & 2.9 \\
\hline 5 & Spiral & 2.8 & 2.8 & 2.6 & 2.5 & 2.6 & 2.7 & 2.8 \\
\hline 6 & Spiral & -- & 2.6 & 2.4 & 2.3 & 2.4 & 2.6 & 2.7 \\
\hline 7 & Coaxial & 0.47 & 0.43 & 0.43 & 0.41 & 0.41 & 0.43 & 0.44 \\
\hline 8 & Coaxial & 0.50 & 0.43 & 0.41 & 0.40 & 0.42 & 0.45 & 0.46 \\
\hline
\end{tabular}




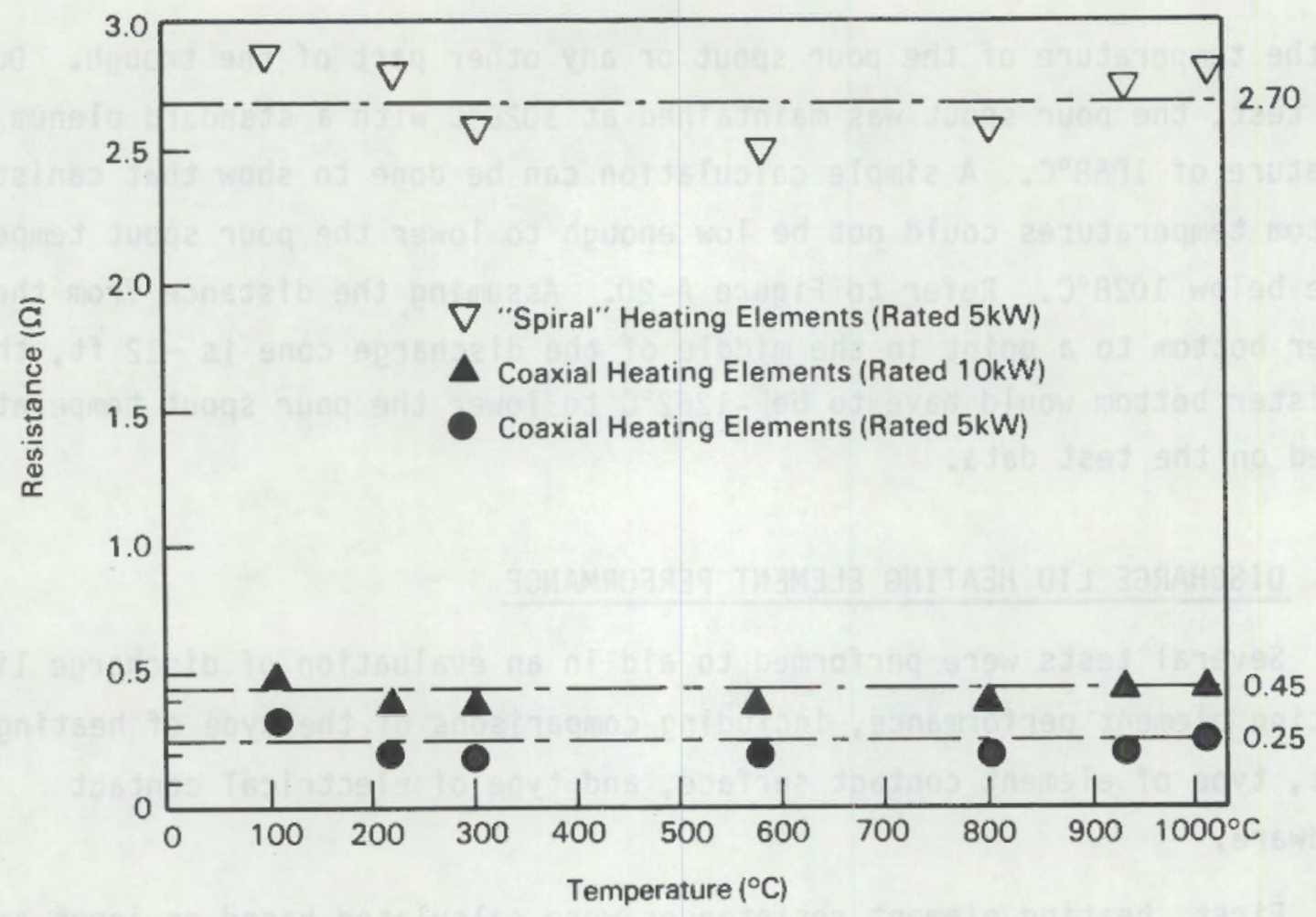

FIGURE A-21. Resistance Values as a Function of Plenum Temperature

During testing under power, three elements failed: one coaxial-type element and three spiral-type elements. After allowing the thermal mockup to cool, the lid was removed, exposing the broken elements as shown in Figure A-22. As can be seen, three of the four spiral elements were broken off. The other failed element, coaxial element \#1, can be seen in the figure to have a long hole in it in the top third of the exposed portion. This element was found to be fragile and, during removal, broke off near the hole. Figure A-23 is a close-up view of broken element \#1. Although difficult to see, the interior wall surface indicated by the arrow was found to be "mealy," suggesting material failure caused by excessively high temperature operation. The nature of the hole burned in the element suggests that nonuniformities present within new elements tend to create hot spots that worsen with time, leading ultimately to element failure. The four elements failed after less than one month of operation. 


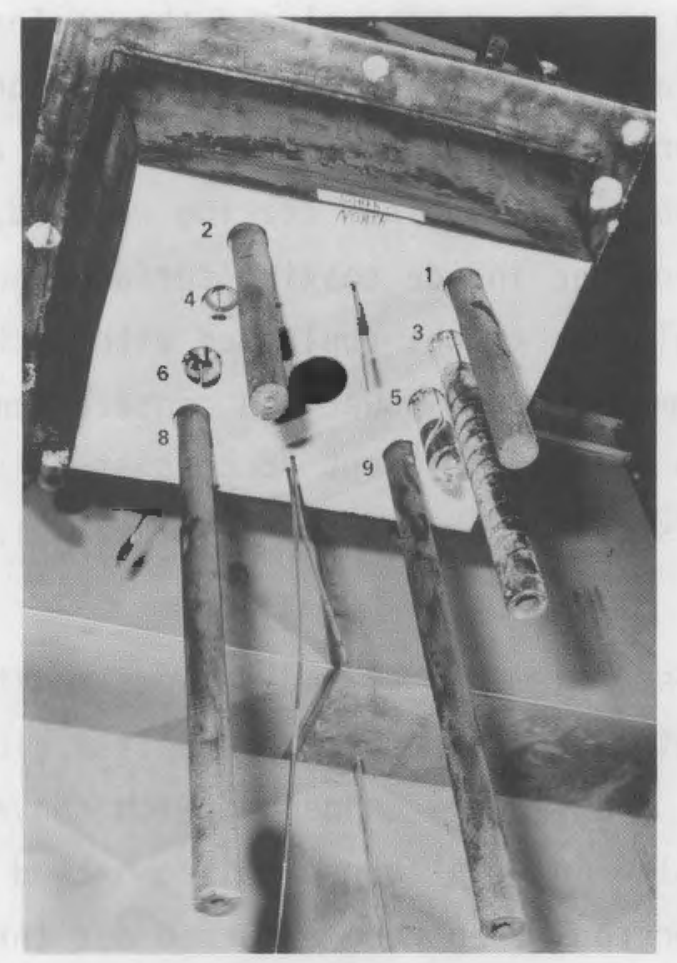

FIGURE A-22. Bottom View of Discharge Lid

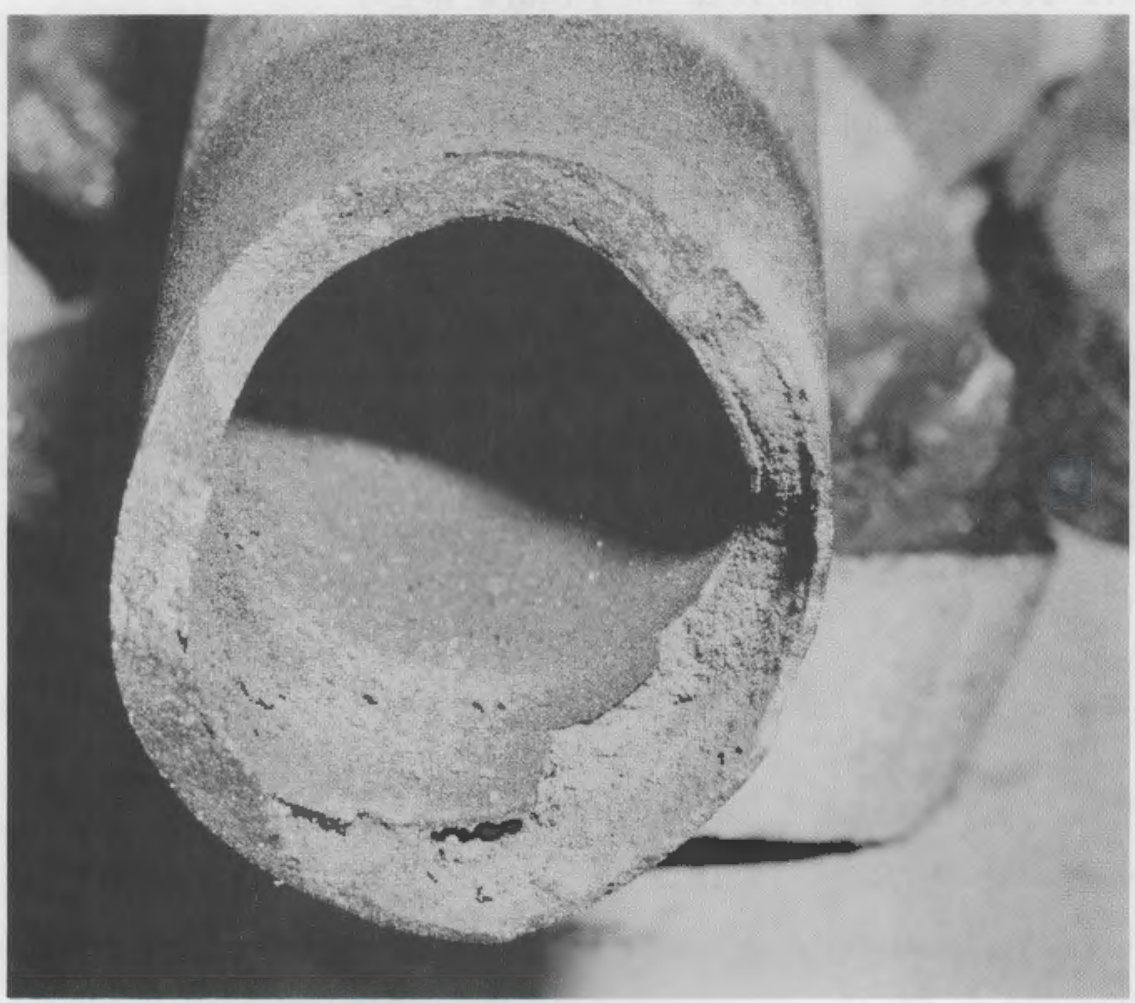

FIGURE A-23. Broken (\#1) Coaxial Heating Element 
Three tests were performed to evaluate the performance of elements having modified contact surfaces. In the first test, the contact temperatures of elements $\# 7$ and $\# 8$ were monitored at fairly constant amperage. Both elements had the manufacturer-applied aluminum coating removed, and element \#7 was replated with copper on the inside coaxial surface and left bare on the outside surface, while element \#8 was replatted with nickel on both coaxial surfaces. Table A-4 summarizes the power and contact temperature data for the two elements. As can be seen, element \#8 consistently ran $\sim 50^{\circ} \mathrm{C}$ lower than element \#7 during this test, indicating the nickel platting to be more effective than copper.

In the second test, elements $\# 7$ and \#8 were monitored along with elements \#1 and \#2; each contained the manufacturer-applied aluminum spray coating. In addition, elements \#1 and \#2 were connected with conventional wire braid/omega clip hardware with a 1/4-in.-dia copper rod connected to the braid within the enclosure. The copper rods then were extended out through the cooled covers and connected to the power system. Elements $\# 7$ and $\# 8$ were connected using the PNL-designed contact clamps with integral 1/4-in.-dia copper leads. The data for this test is summarized in Figure A-24.

TABLE A-4. Comparison of Element Power and Temperature Data

\begin{tabular}{|c|c|c|c|c|c|}
\hline $\begin{array}{l}\text { Trial } \\
\text { Number } \\
\end{array}$ & $\begin{array}{l}\text { Element } \\
\text { Number } \\
\end{array}$ & Amps & $\begin{array}{c}\text { Power, } \\
\mathrm{kW}\end{array}$ & $\begin{array}{c}\text { Contact } \\
\text { Temp., }{ }^{\circ} \mathrm{C} \\
\end{array}$ & $\begin{array}{l}\text { Plenum } \\
\text { Temp., }{ }^{\circ} \mathrm{C} \\
\end{array}$ \\
\hline 1 & $\begin{array}{l}7 \\
8\end{array}$ & $\begin{array}{l}18.6 \\
18.6\end{array}$ & $\begin{array}{l}0.27 \\
0.24\end{array}$ & $\begin{array}{l}249 \\
186\end{array}$ & 265 \\
\hline 2 & $\begin{array}{l}7 \\
8\end{array}$ & $\begin{array}{l}18.7 \\
18.6\end{array}$ & $\begin{array}{l}0.32 \\
0.23\end{array}$ & $\begin{array}{l}260 \\
187\end{array}$ & 273 \\
\hline 3 & $\begin{array}{l}7 \\
8\end{array}$ & $\begin{array}{l}18.5 \\
18.3\end{array}$ & $\begin{array}{l}0.24 \\
0.23\end{array}$ & $\begin{array}{l}250 \\
201\end{array}$ & 280 \\
\hline 4 & $\begin{array}{l}7 \\
8\end{array}$ & $\begin{array}{l}18.3 \\
18.3\end{array}$ & $\begin{array}{l}0.24 \\
0.23\end{array}$ & $\begin{array}{l}244 \\
188\end{array}$ & 285 \\
\hline 5 & $\begin{array}{l}7 \\
8\end{array}$ & $\begin{array}{l}18.3 \\
18.2\end{array}$ & $\begin{array}{l}0.20 \\
0.20\end{array}$ & $\begin{array}{l}231 \\
183\end{array}$ & 290 \\
\hline
\end{tabular}




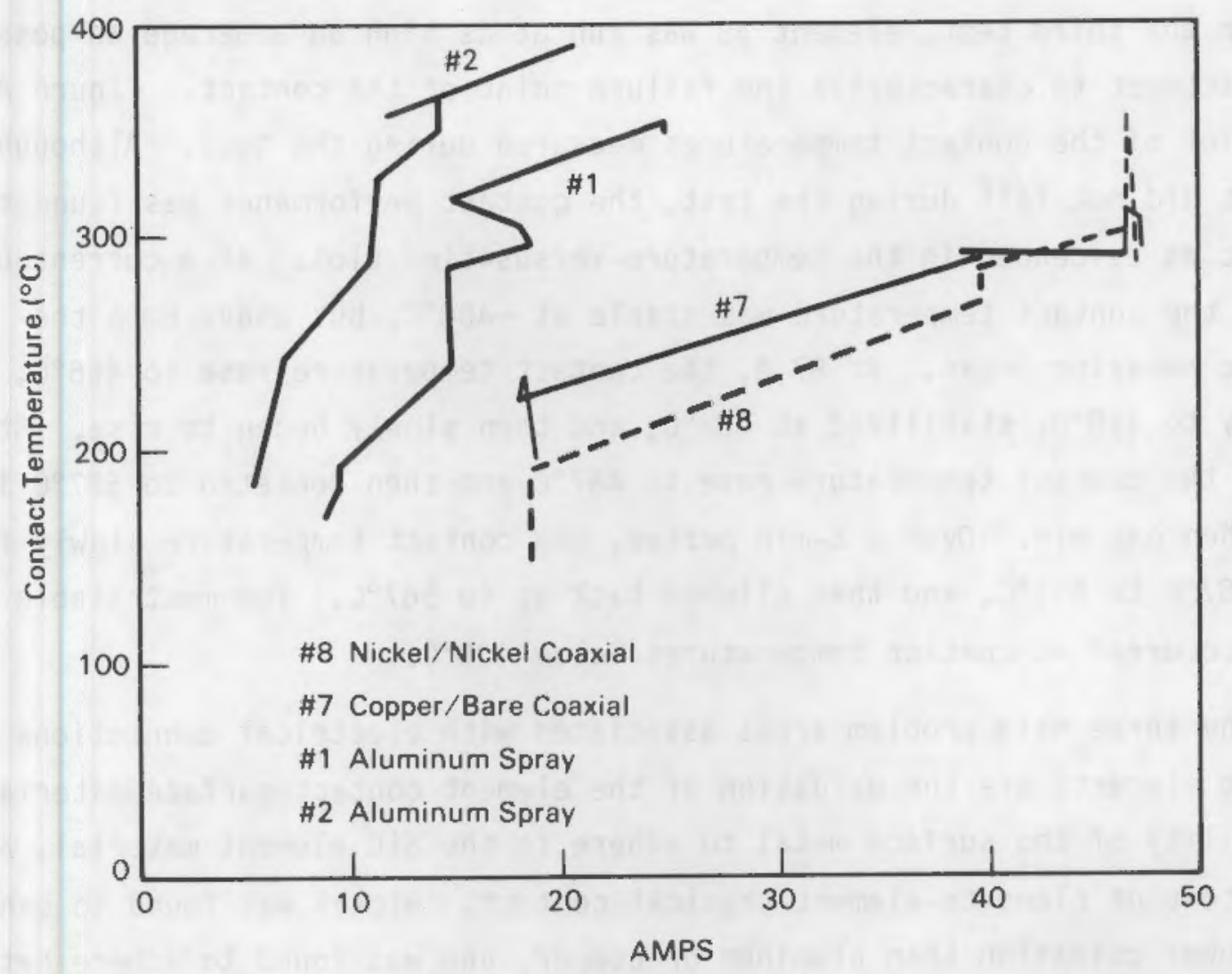

FIGURE A-24. Comparison of Element Contact Temperatures

As can be seen, the contact surfaces of elements \#7 and \#8 ran between $50^{\circ} \mathrm{C}$ and $120^{\circ} \mathrm{C}$ cooler than element $\# 1$, and between $70^{\circ} \mathrm{C}$ and $140^{\circ} \mathrm{C}$ cooler than element \#2. This strongly suggests that the PNL-designed electrical connection system is preferable. Note further that element \#8 (nickel surface) again ran cooler than element \#7 (copper surface), except at the end of the test.

Following this test, the cooled covers were opened and the contacts inspected. The contact clamp on element \#8 was found to be an extremely loose fitting, possibly explaining the rise in temperature at the end of the second test. Both of the PNL-designed contact clamps on elements \#7 and \#8 were discolored and severe damage to the contact interface bands was noted, indicating relatively poor surface contact. Even so, the PNL-designed clamps ran significantly cooler than the conventional hardware. 
In the third test, element \#8 was run at as high an amperage as possible in an attempt to characterize the failure point of the contact. Figure $\mathrm{A}-25$ is a plot of the contact temperatures measured during the test. Although the contact did not fail during the test, the contact performance was found to be erratic as evidenced in the temperature-versus-time plot. At a current of $\sim 80 \mathrm{~A}$, the contact temperature was stable at $\sim 400^{\circ} \mathrm{C}$, but above $80 \mathrm{~A}$ the erratic behavior began. At $87 \mathrm{~A}$, the contact temperature rose to $456^{\circ} \mathrm{C}, \mathrm{fell}$ quickly to $410^{\circ} \mathrm{C}$, stabilized at $408^{\circ} \mathrm{C}$, and then slowly began to rise. At $100 \mathrm{~A}$, the contact temperature rose to $467^{\circ} \mathrm{C}$ and then rocketed to $587^{\circ} \mathrm{C}$ in less than one min. Over a 5-min period, the contact temperature slowly fell from $587^{\circ} \mathrm{C}$ to $551^{\circ} \mathrm{C}$, and then climbed back up to $567^{\circ} \mathrm{C}$. The most stable operation occurred at contact temperatures below $400^{\circ} \mathrm{C}$.

The three main problem areas associated with electrical connections to heating elements are the oxidation of the element contact surface material, the ability of the surface metal to adhere to the SiC element material, and the extent of clamp-to-element physical contact. Nickel was found to exhibit much lower oxidation than aluminum or copper, and was found to adhere better than copper when plated on. It is therefore recommended that elements be first stripped of their manufacturer-applied aluminum spray coating and plated with 50 microns of nickel. A second choice would be to strip off the aluminum (using strong $\mathrm{NaOH}$ ) and leave the element surface bare. Tests of longer duration would distinguish the better method.

The use of stiff, round element contact clamps was found to create a problem since the elements were found to be substantially out of round, preventing good physical contact between the element and clamp. A solution would be to replace the unnecessarily thick 1/4-in. clamp material with a more deformable 1/8-in. material, and switch from phosphorous bronze to electrolytic copper. The thinner, more malleable material could be clamped down tightly onto the elements using the same type of hose clamp as was used on the spiral element wire braid hardware. The hose clamp would also minimize the loosening (due to thermal expansion) of the contact hardware observed during testing. The result would be a better than available, high temperature, high power contact method. 


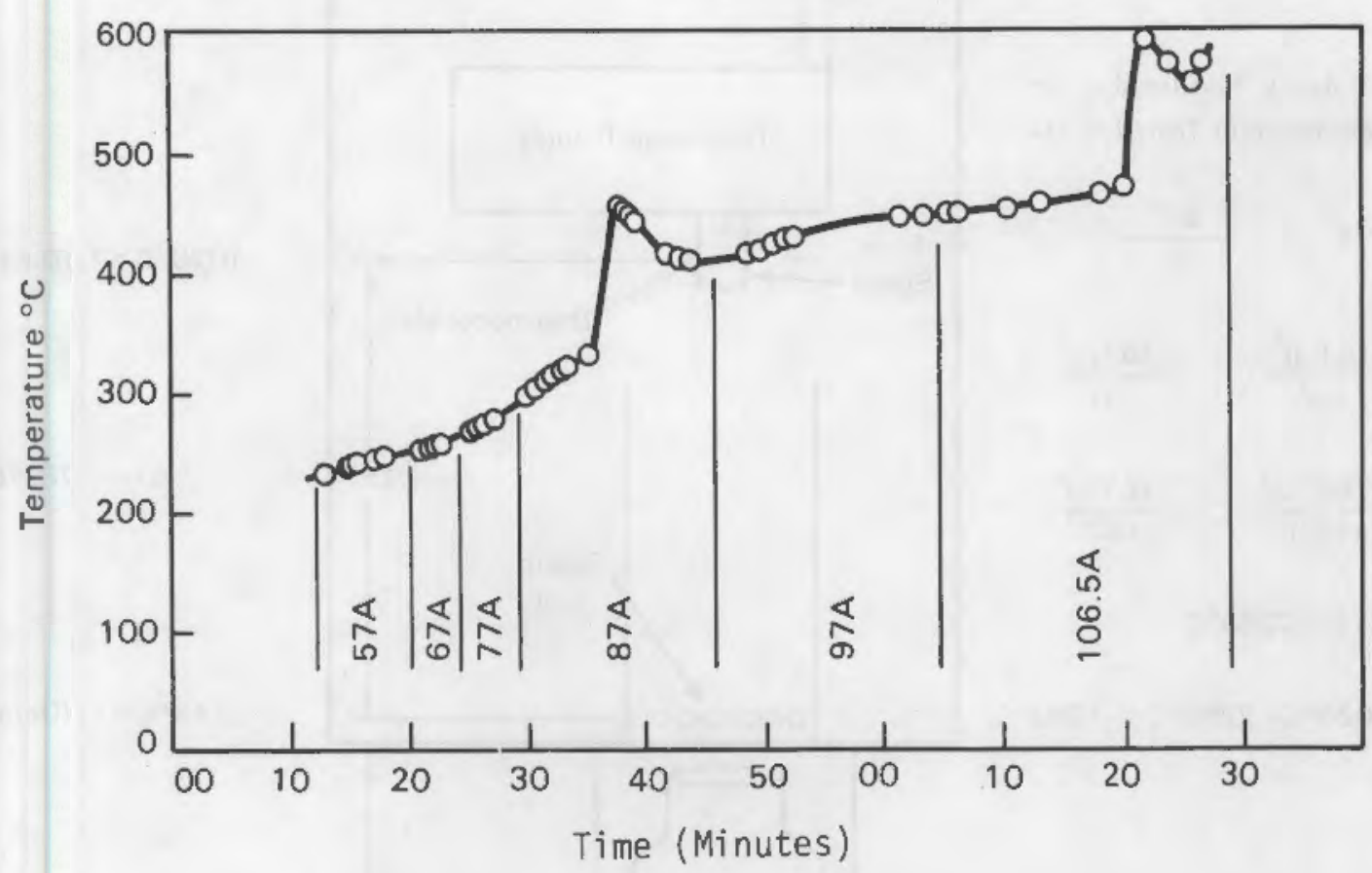

FIGURE A-25. High Temperature Element Contact Performance Data

\section{A.8 VARYING COOLANT TO DISCHARGE LID COOLING COVERS}

Figure A-27 is a sketch of a cooled cover showing the location on the lid of the covers, location of the elements within the covers, thermocouple locations, the direction of flow through the jacketed cover walls, and nomenclature. Note that thermocouples were used on two elements in each lid to record element contact temperatures.

In the first tests, air at $10.6 \mathrm{scfm}$ and $21.3 \mathrm{scfm}$ was run through the covers resulting in average contact environment temperatures of $246^{\circ} \mathrm{C}$ and $224^{\circ} \mathrm{C}$, respectively. The heat removed by the air flowing through the covers was calculated based on inlet and outlet temperatures in conjunction with air mass flow rate. The average heat duty per cover at $10.6 \mathrm{scfm}$ air flow was $1.75 \mathrm{~kW}$ and $2.80 \mathrm{~kW}$ at $21.3 \mathrm{scfm}$ air flow. Figure A-28 summarizes the temperature data associated with the air flow tests.

In the second test, water was used as the element cover cooling media. Due to difficulties with water flow measurements, neither heat duty nor flow rate data are available. During this test, the average contact environment 


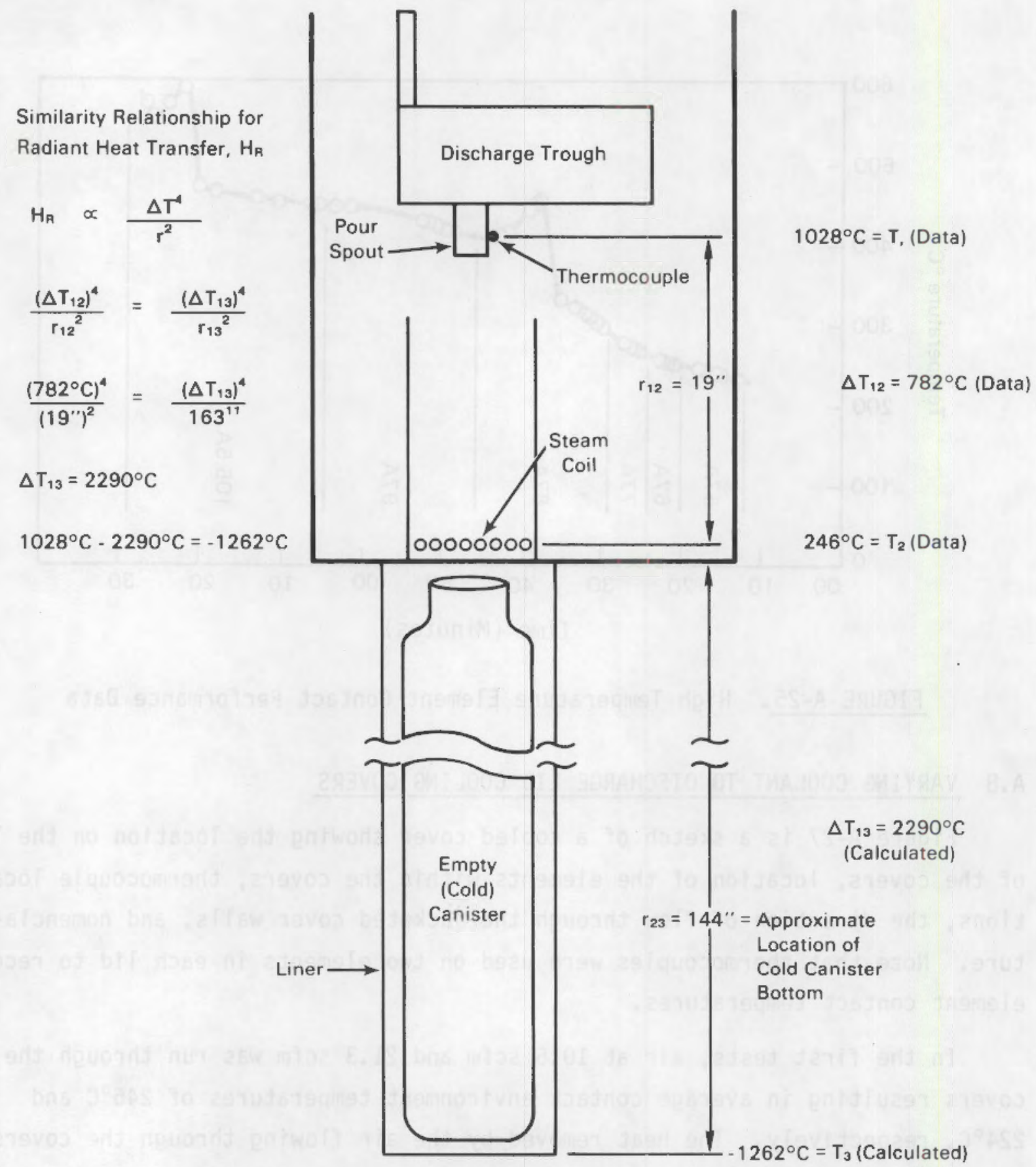

FIGURE A-26. Effect of Presence of Cold Canister on Pour Spout Temperature 


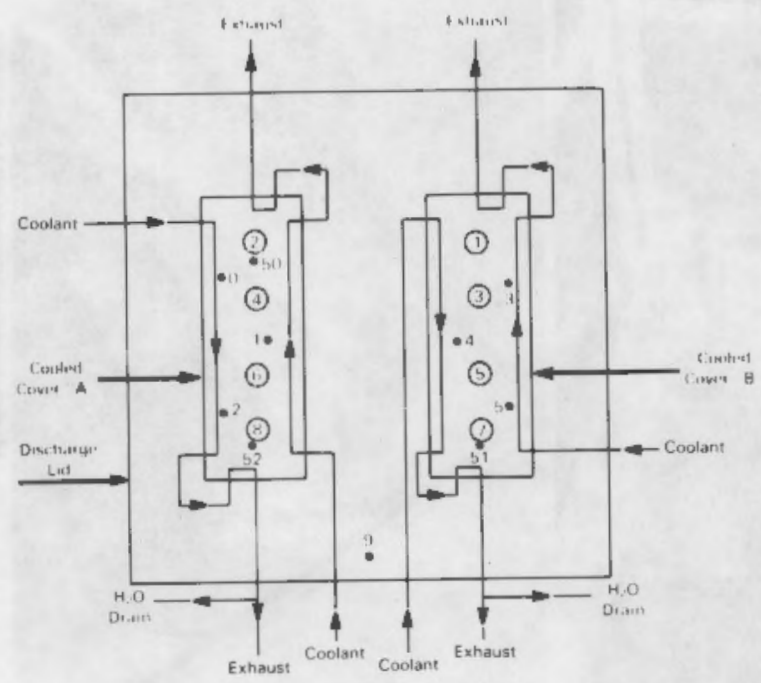

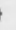

\begin{tabular}{|c|c|c|c|}
\hline \multicolumn{4}{|c|}{ Water Cooling } \\
\hline \multicolumn{2}{|c|}{ Power } & \multicolumn{2}{|c|}{ Temperatures } \\
\hline Element 1 & $2.23 \mathrm{~kW}$ & Loc 0 & $215^{\circ} \mathrm{C}$ \\
\hline Element 2 & $1.75 \mathrm{~kW}$ & Loc 1 & $251^{\circ} \mathrm{C}$ \\
\hline Element 3 & $436 \mathrm{~kW}$ & Loc 2 & $279^{\circ} \mathrm{C}$ \\
\hline Element 4 & $460 \mathrm{~kW}$ & Loc 3 & $262^{\circ} \mathrm{C}$ \\
\hline Element 5 & $443 \mathrm{~kW}$ & $\operatorname{Loc} 4$ & $210^{\circ} \mathrm{C}$ \\
\hline Element 6 & $425 \mathrm{~kW}$ & Loc 5 & $196^{\circ} \mathrm{C}$ \\
\hline Element? & $0 \mathrm{~kW}$ & $\operatorname{Loc} 50$ & $377^{\circ} \mathrm{C}$ \\
\hline Element 8 & $0.91 \mathrm{~kW}$ & Loc. 51 & $166^{\circ} \mathrm{C}$ \\
\hline Heaters & $3.59 \mathrm{~kW}$ & Loc 52 & $310^{\circ} \mathrm{C}$ \\
\hline Total & $26.12 \mathrm{~kW}$ & Loc. 9 & $180^{\circ} \mathrm{C}$ \\
\hline
\end{tabular}

AIr Cooling at 21.3 SCFH

\begin{tabular}{|c|c|c|c|}
\hline \multicolumn{2}{|c|}{ Power } & \multicolumn{2}{|c|}{ Tomperatures } \\
\hline ent 1 & $2.22 \mathrm{~kW}$ & Loc 0 & $203^{\circ} \mathrm{C}$ \\
\hline ment 2 & $174 \mathrm{~kW}$ & Loc 1 & $238^{\circ} \mathrm{C}$ \\
\hline ment 3 & $435 \mathrm{~kW}$ & Loc 2 & $243^{\circ} \mathrm{C}$ \\
\hline ment 4 & $4.58 \mathrm{~kW}$ & Loc 3 & $272^{\circ} \mathrm{C}$ \\
\hline ment 5 & $441 \mathrm{kw}$ & Loc 4 & $205^{\circ} \mathrm{C}$ \\
\hline ment 6 & $426 \mathrm{~kW}$ & Loc 5 & $179^{\circ} \mathrm{C}$ \\
\hline nent 7 & okw & Loc 50 & $381 \mathrm{C}$ \\
\hline ent 8 & $091 \mathrm{~kW}$ & Loc 51 & $147^{\circ} \mathrm{C}$ \\
\hline lers & $359 \mathrm{kw}$ & Loc 52 & $325^{\circ} \mathrm{C}$ \\
\hline & $26.06 \mathrm{~kW}$ & LoC 9 & $184^{\circ} \mathrm{C}$ \\
\hline
\end{tabular}

Plenum $100^{\circ} \mathrm{C}$

\begin{tabular}{|c|c|c|c|}
\hline \multicolumn{2}{|c|}{ Power } & \multicolumn{2}{|c|}{ Temperalures } \\
\hline Element 1 & $2.24 \mathrm{~kW}$ & Lec 0 & 229 \\
\hline Element 2 & $178 \mathrm{~kW}$ & Loc 1 & 259 \\
\hline Element 3 & $437 \mathrm{~kW}$ & $\operatorname{Loc} 2$ & 263 \\
\hline Element 4 & $459 \mathrm{~kW}$ & Loc 3 & 290 \\
\hline Element 5 & $441 \mathrm{~kW}$ & Loc 4 & 234 \\
\hline Element 6 & $428 \mathrm{~kW}$ & Loc 5 & 201 \\
\hline Element 7 & $0 \mathrm{~kW}$ & Loc 50 & 389 \\
\hline Element 8 & $0.92 \mathrm{~kW}$ & Lac 51 & $168^{\circ}$ \\
\hline Heaters & $408 \mathrm{~kW}$ & Loc 52 & 338 \\
\hline Iotal & $2667 \mathrm{~kW}$ & Loc 9 & 183 \\
\hline
\end{tabular}

\begin{tabular}{llll}
\multicolumn{3}{c}{ No Cooling } \\
\multicolumn{3}{c}{ Power } & \multicolumn{3}{c}{ Temperatures } \\
Element 1 & $224 \mathrm{~kW}$ & Loc 0 & $278^{\circ} \mathrm{C}$ \\
Element 2 & $175 \mathrm{~kW}$ & Loc 1 & $303^{\circ} \mathrm{C}$ \\
Element 3 & $4.37 \mathrm{~kW}$ & Loc 2 & $328^{\circ} \mathrm{C}$ \\
Element 4 & $461 \mathrm{~kW}$ & Loc 3 & $315^{\circ} \mathrm{C}$ \\
Element 5 & $4.43 \mathrm{~kW}$ & Loc 4 & $273^{\circ} \mathrm{C}$ \\
Element 6 & $425 \mathrm{~kW}$ & Loc 5 & $251^{\circ} \mathrm{C}$ \\
Element 7 & $0 \mathrm{~kW}$ & Loc 50 & $412^{\circ} \mathrm{C}$ \\
Element 8 & $092 \mathrm{~kW}$ & Loc 51 & $210^{\circ} \mathrm{C}$ \\
Heaters & $359 \mathrm{~kW}$ & Loc 52 & $357^{\circ} \mathrm{C}$ \\
Total & $26.16 \mathrm{~kW}$ & Loc 9 & $191^{\circ} \mathrm{C}$ \\
& & Plenum & $1093^{\circ} \mathrm{C}$
\end{tabular}

FIGURE A-27. Cooled Heating Element Contact Enclosure Performance Data 


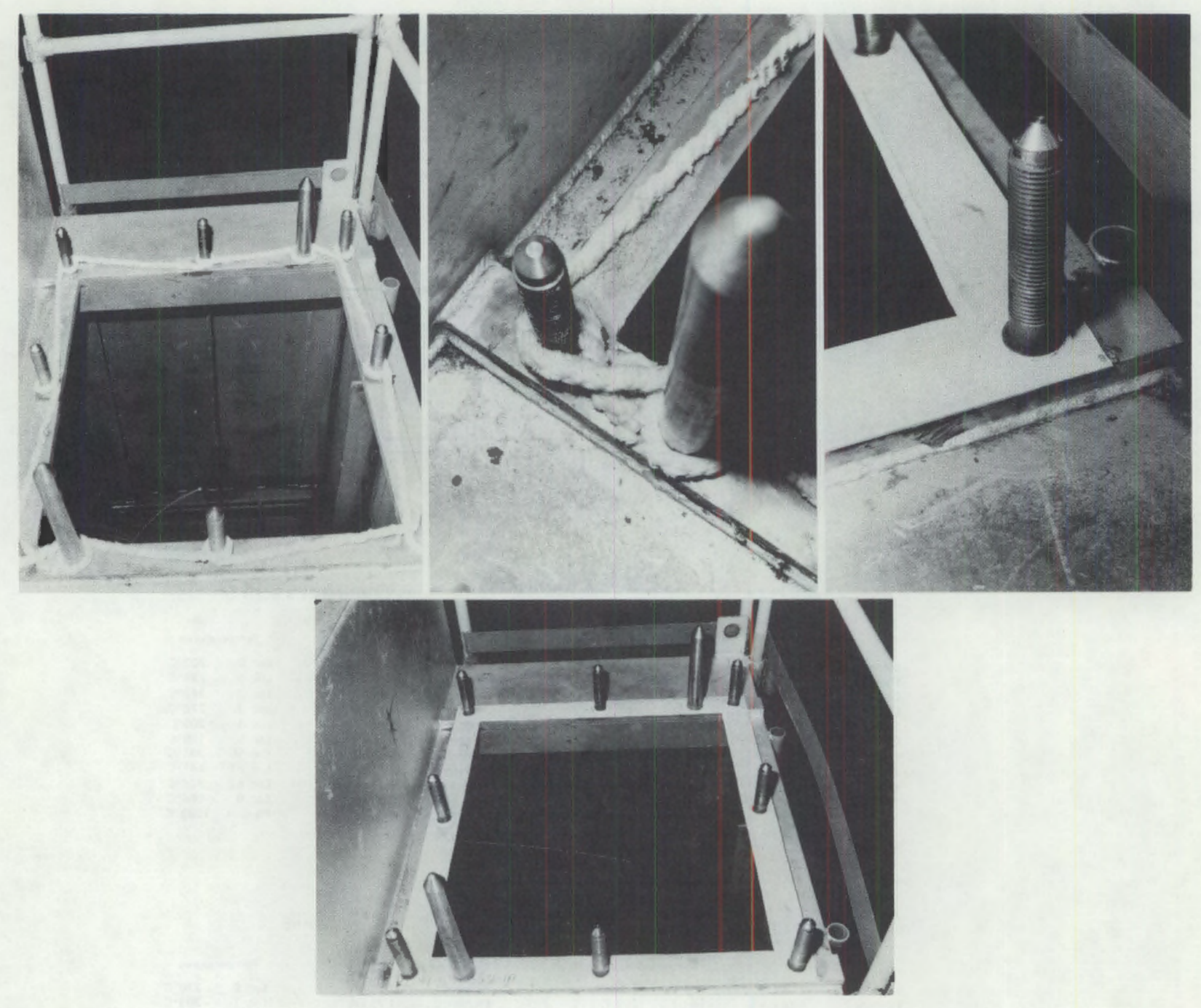

FIGURE A-28. Garlock and Rope Gaskets on Melter Shell Flange

temperature was maintained at $236^{\circ} \mathrm{C}$. Other temperature data is shown in Figure A-27.

In the third test, the element enclosures were allowed to run with no cooling other than natural convection to the test environment. The temperature data for this case is also shown in Figure A-27. As can be seen, the average contact environment temperature for this case was $291^{\circ} \mathrm{C}$.

A comparison of average contact environment temperatures shows comparable results between air and water cooling. The cooling covers without cooling 
have the highest contact environment temperature. However, temperatures for the contact environment are still relatively low with just the metal covers over the elements. During tests without cooling covers, where the contact environment was on the order of $80^{\circ} \mathrm{C}$ to $180^{\circ} \mathrm{C}$ due to poor air circulation in the test area, steady state contact temperature for one element was $390^{\circ} \mathrm{C}$ at similar plenum and power conditions. This further suggests no cooling is necessary.

Contact temperatures stayed low enough in the noncooled cooling covers to allow the elements to function properly. This suggests that sheetmetal covers without cooling jackets would run cool enough, especially if the covers are designed to maximize radiant heat transfer. The covers should be small since radiant heat transfer decreases with distance squared. Noncooled covers reduce the overall discharge inleakage significantly without adding any design complexities.

\section{A.9 EVALUATION OF DISCHARGE LID AIR INLEAKAGE}

The inleakage associated with two types of gasket, flat 1/8-in.-thick garlock gasket material, and round 1-in.-dia. ceramic fiber rope, was measured over a series of melter shell vacuums and positive pressures. Figure A-28 shows the garlock and rope gaskets as they appear on the melter shell flange prior to discharge lid installation. The base rate of inleakage with all flanges sealed airtight was found to be essentially negligible, less than $0.25 \mathrm{cfm}(15 \mathrm{cfh})$ at $-2 \mathrm{D} .00 \mathrm{in}$. $\mathrm{H}_{2} \mathrm{O}$ and $30^{\circ} \mathrm{C}$. Figure $\mathrm{A}-29$ is a plot of inleakage, calculated in scfh at each vacuum, versus melter shell vacuum, for the case with garlock as the lid gasket and ceramic felt and conax fittings as the sealing method used for the two cooled covers on the lid. At $-10 \mathrm{in}$. $\mathrm{H}_{2} \mathrm{O}$, total inleakage is $250 \mathrm{scfh}$. Figure $\mathrm{A}-30$ is a similar plot for the case with garlock as the lid gasket, but with the cooled cover blanked off (sealed airtight). At $-10 \mathrm{in} . \mathrm{H}_{2} \mathrm{O}$, inleakage of the garlock-gasket-only is $130 \mathrm{scfh}$. Comparison of Figures $A-29$ and $A-30$ reveal that the rate of inleakage through the cooled covers accounts for $\sim 50 \%$ of the lid inleakage at -10 in. $\mathrm{H}_{2} \mathrm{O}$ when garlock is used as the gasket (120 scfh of the total $250 \mathrm{scfh}$ when the melter shell is at $-10 \mathrm{in} . \mathrm{H}_{2} \mathrm{O}$ ). This percentage decreases to $25 \%$ at $-5 \mathrm{in}$. $\mathrm{H}_{2} \mathrm{O}$. 


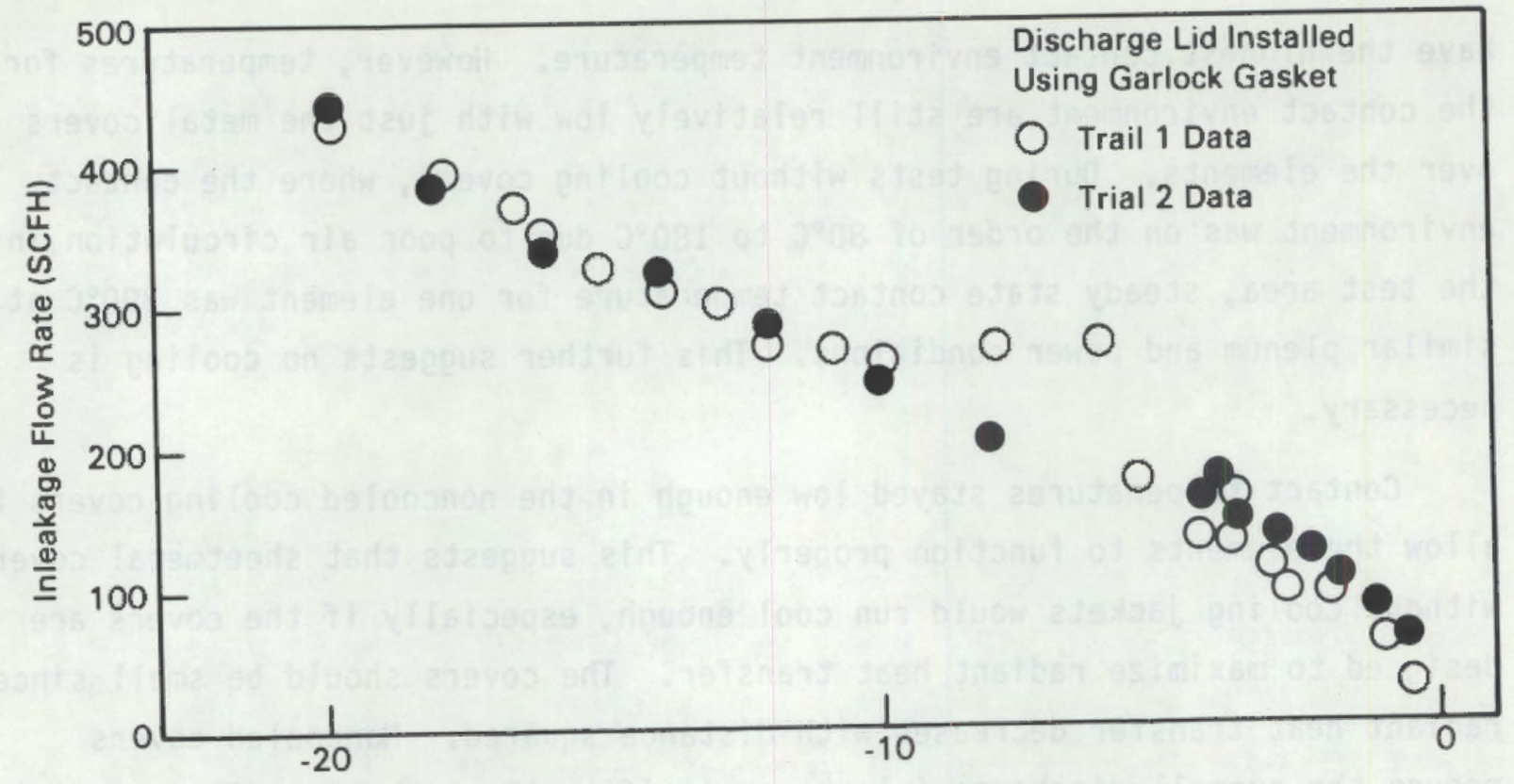

Melter Shell Vacuum (in $\mathrm{H}_{2} \mathrm{O}$ )

FIGURE A-29. Combined Air Inleakage Through Garlock Lid Gasket and Cooled Covers

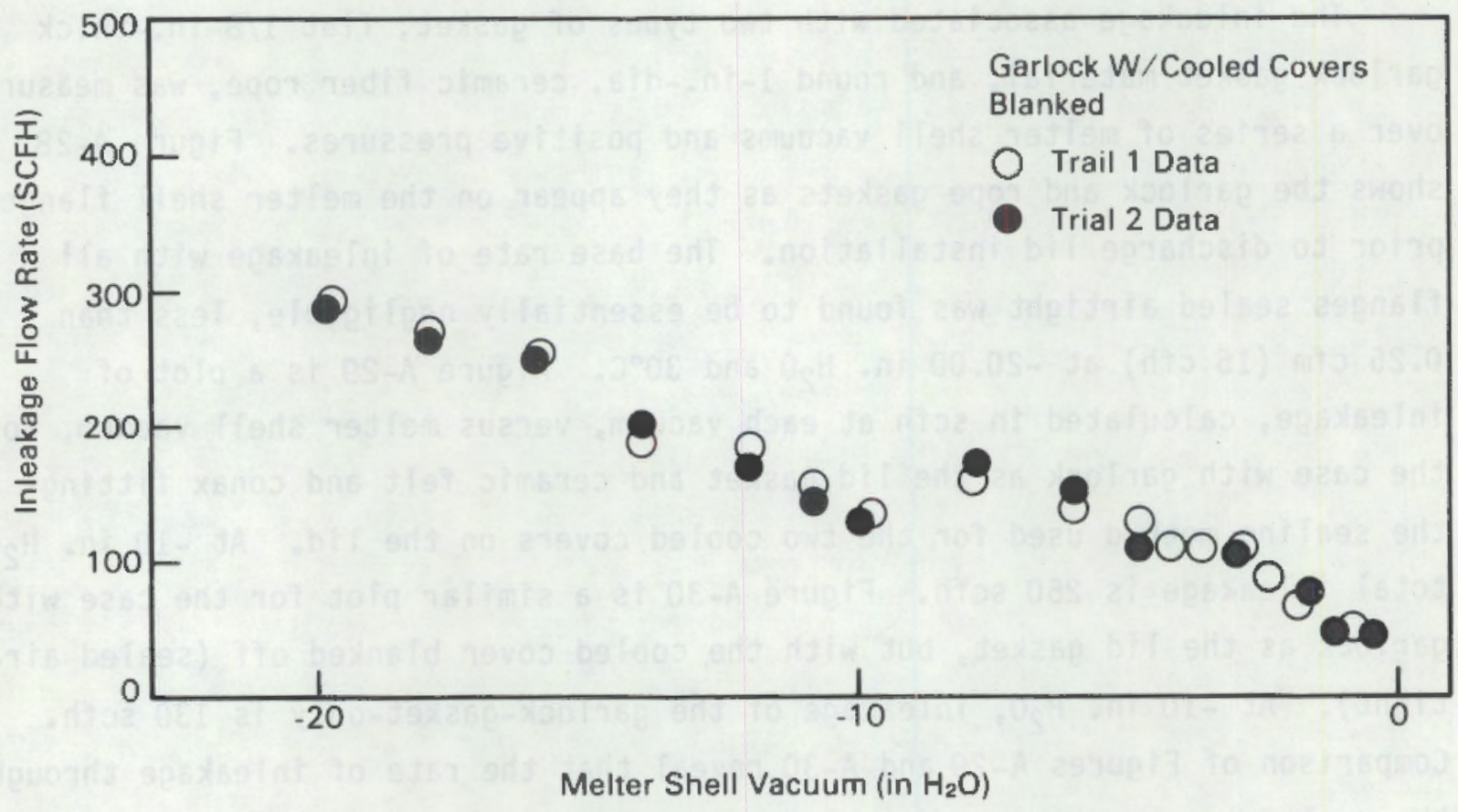

FIGURE A-30. Air Inleakage Through Garlock Lid Gasket Only 
Figure $A-31$ is a similar plot for the case with ceramic rope as the lid gasket and the cooled cover blanked. At -10 in. $\mathrm{H}_{2} \mathrm{O}$, inleakage of the rope-gasketonly is $150 \mathrm{scfh}$. It is interesting to note the unexpected result that the inleakage associated with the rope gasket is only $15 \%$ of that associated with the garlock gasket. A possible explanation is that three passes were required to fully tighten the lid onto the rope gasket. After one pass, many of the lid bolts were relatively loose and it is possible that in previous gasket applications flanges were not fully tightened, leading to higher than achievable inleakage rates.

An attempt was made to correlate the rate of inleakage and melter vacuum for the rope and garlock gaskets using the standard orifice pressure drop versus flow form:

$$
F=c_{1} \frac{\sqrt{\Delta P}}{\sqrt{\rho}} \sqrt{g_{c}}
$$

where $F$ is flow rate in scfh, $C_{1}$ is the orifice number (constant) with dimensions $\frac{\mathrm{ft}^{2} \mathrm{~s}}{\mathrm{~h}}, \Delta \mathrm{P}$ is the melter shell vacuum in $1 \mathrm{~b}_{\mathrm{f}} / \mathrm{ft}^{2}, \rho$ is air density in $1 \mathrm{bm} / \mathrm{ft}^{3}$ and $g_{C}$ is the gravitational constant equal to $32.174 \frac{1 b_{m} f t}{1 b_{f} s}$. When plotted in the form of equation (A.1), the data is very linear, as can be seen in Figure $\mathrm{A}-32$. The lines drawn through the points and their characteristic equations are shown in the figure. Two lines were required to fit each of the gasket data since two rotameters, having imperfect calibration, were required to span the air flow range. Since the slopes of both lines must be identical for a constant orifice number, the average slope is calculated for each gasket's characteristic orifice number. The intercept values also indicate imperfect calibration since flow must equal 0 at a pressure drop equal to 0 . Since the slopes of the lines are similar, suggesting constant rotameter offsets, the intercept values are considered equivalent to rotameter offset and are thus deleted in the orifice equations of each gasket. The equations thus derived are, for the garlock gasket,

$$
F=17 \frac{\sqrt{\Delta P}}{\sqrt{\rho_{m}}} \sqrt{g_{C}}
$$




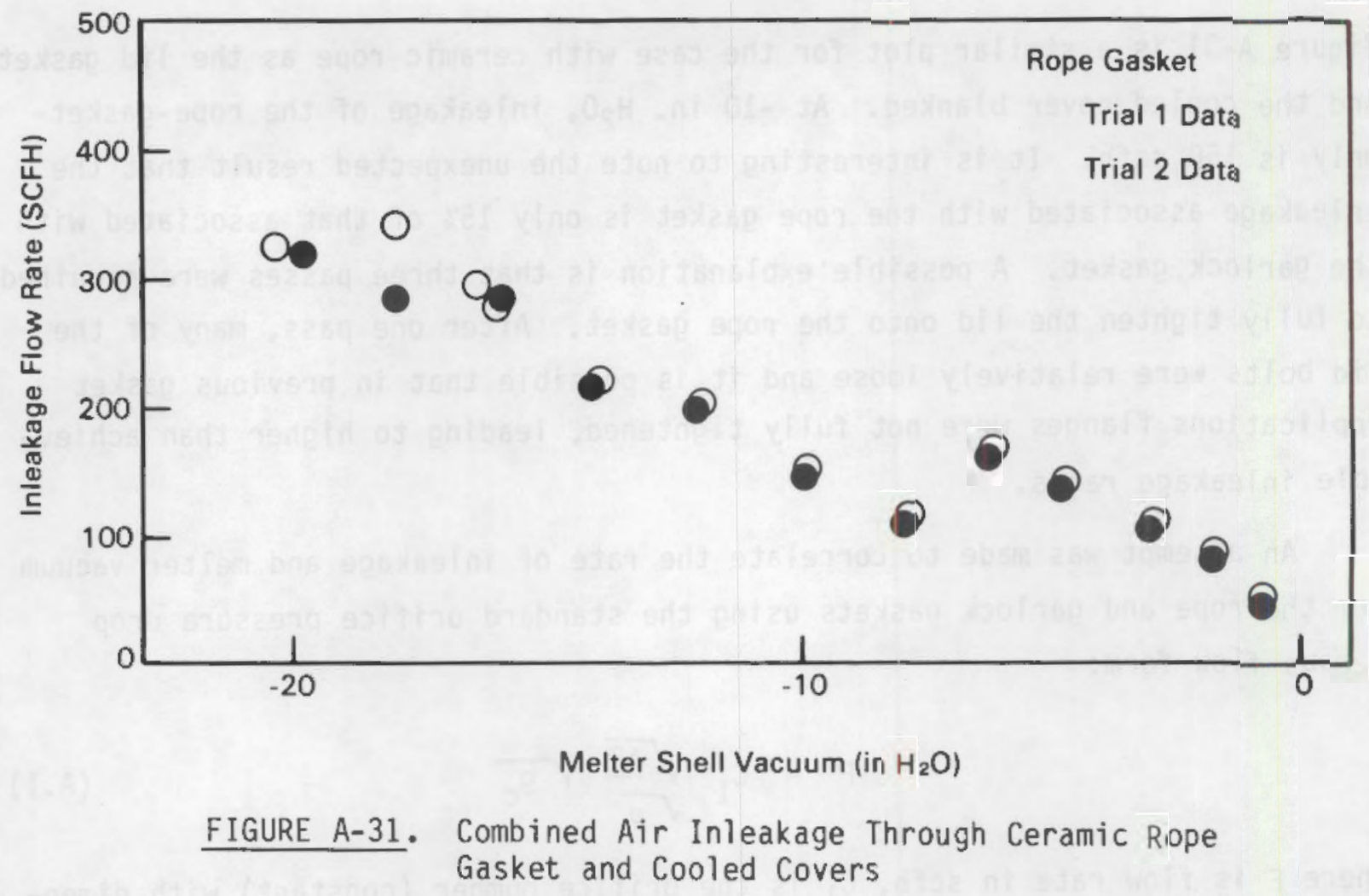




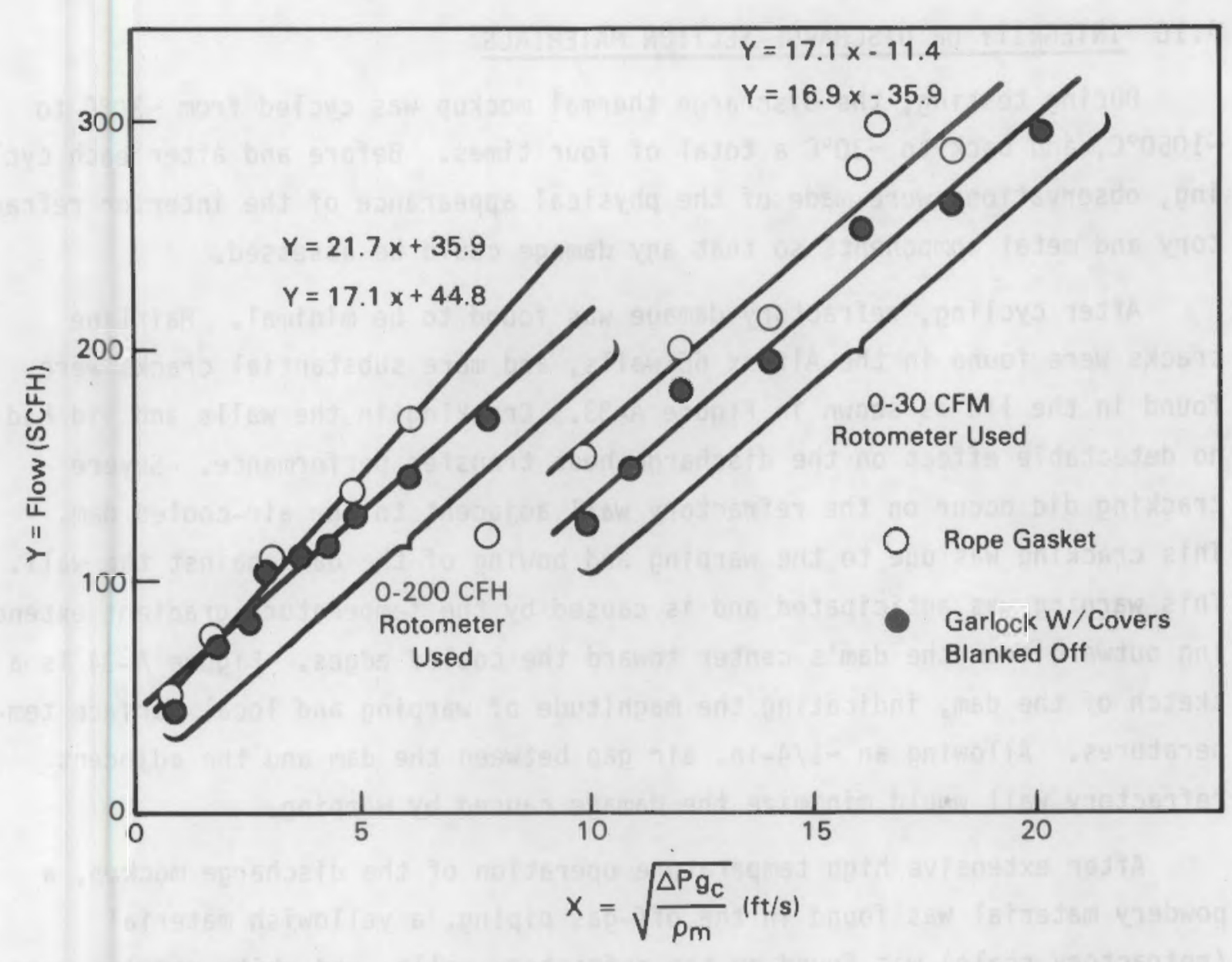

FIGURE A-32. Characterization of Lid Gasket Inleakage

and, for the rope gasket,

$$
F=19.4 \frac{\sqrt{\frac{\Delta P}{}}}{\sqrt{\rho_{m}}} \sqrt{g_{c}}
$$

The inleakage behavior of the two 1 id gasket materials are characterized over the range of 0 to $-20 \mathrm{in} . \mathrm{H}_{2} \mathrm{O}$ by these equations where $\mathrm{F}$ is flow in scfh, $\Delta \mathrm{P}$ is vacuum in $1 b_{f} / \mathrm{ft}^{2}$ (absolute) and $\rho_{m}$ is the arithmetic mean value of air density at atmospheric pressure and at the absolute vacuum pressure in $1 \mathrm{~b}_{\mathrm{m}} / \mathrm{ft}^{3}$. 


\section{A.10 INTEGRITY OF DISCHARGE SECTION MATERIALS}

During testing, the discharge thermal mockup was cycled from $\sim 30^{\circ} \mathrm{C}$ to $\sim 1050^{\circ} \mathrm{C}$, and back to $\sim 30^{\circ} \mathrm{C}$ a total of four times. Before and after each cycling, observations were made of the physical appearance of the interior refractory and metal components so that any damage could be assessed.

After cycling, refractory damage was found to be minimal. Hairline cracks were found in the Alfrax 66 walls, and more substantial cracks were found in the lid as shown in Figure A-33. Cracking in the walls and lid had no detectable effect on the discharge heat transfer performance. Severe cracking did occur on the refractory wall adjacent to the air-cooled dam. This cracking was due to the warping and bowing of the dam against the wall. This warping was anticipated and is caused by the temperature gradient extending outward from the dam's center toward the cooled edges. Figure A-34 is a sketch of the dam, indicating the magnitude of warping and local surface temperatures. Allowing an $\sim 1 / 4-i n$. air gap between the dam and the adjacent refractory wall would minimize the damage caused by warping.

After extensive high temperature operation of the discharge mockup, a powdery material was found in the off-gas piping, a yellowish material (refractory scale) was found on the refractory walls, and white nodules were found on some of the heating elements, particularly the "spiral" type elements. Chemical analyses were performed on these materials with the results as shown in Table A-5. The powdery off-gas material was found to consist mainly of $\mathrm{SiO}_{2}, \mathrm{MoO}_{2}, \mathrm{Fe}_{2} \mathrm{O}_{3}, \mathrm{Cr}_{2} \mathrm{O}$ and $\mathrm{Al}_{2} \mathrm{O}_{3}$. The refractory scale was found 


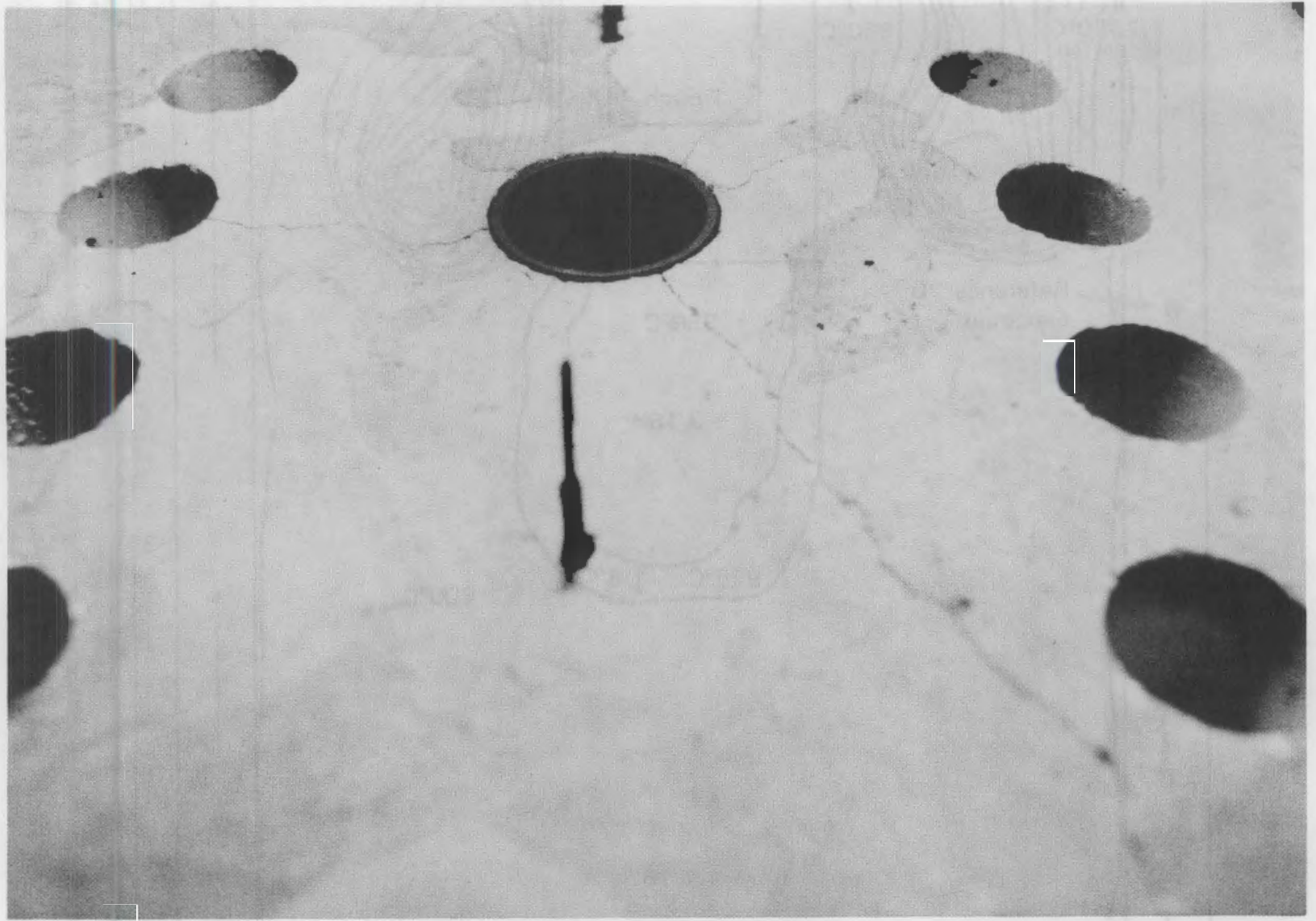

FIGURE A-33. Discharge Section Lid Shown After Testing

to be primarily $\mathrm{Al}_{2} \mathrm{O}_{3}$, with a small amount of other compounds presumably responsible for the yellowish color. The white nodule-like deposits on the spiral elements were found to be primarily $\mathrm{SiO}_{2}$. 


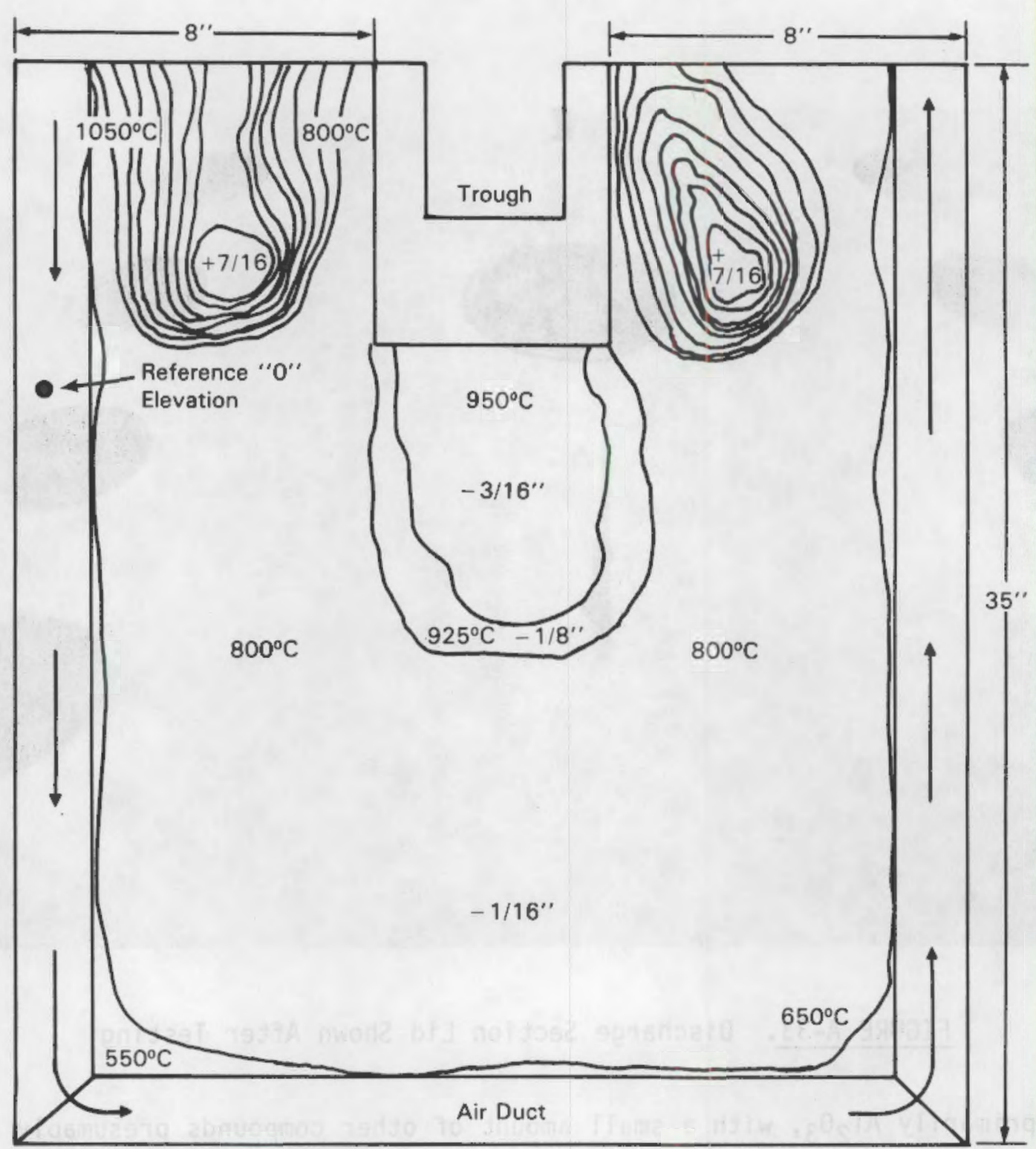

Note: Contour lines are $1 / 16^{\prime \prime}$ increments

FIGURE A-34. Characterization of Dam Warpage 
TABLE A-5. Chemical Analyses

\begin{tabular}{|c|c|c|c|}
\hline 0xide & $\begin{array}{l}\text { Refractory } \\
\text { Scale } \\
\end{array}$ & $\begin{array}{l}\text { Off-Gas } \\
\text { Power }\end{array}$ & $\begin{array}{c}\text { Material } \\
\text { On Elements } \\
\end{array}$ \\
\hline $\mathrm{Al}_{2} \mathrm{O}_{3}$ & 37.4 & 7.83 & 0.72 \\
\hline $\mathrm{B}_{2} \mathrm{O}_{3}$ & -- & 0.90 & 0.26 \\
\hline $\mathrm{CaO}$ & 4.49 & 1.12 & 0.25 \\
\hline $\mathrm{Cr}_{2} \mathrm{O}$ & 0.54 & 6.52 & 0.03 \\
\hline$c_{u}{ }^{0}$ & 0.04 & 3.31 & 0.03 \\
\hline $\mathrm{Fe}_{2} \mathrm{O}_{3}$ & 0.81 & 19.0 & 0.31 \\
\hline $\mathrm{K}_{2} \mathrm{O}$ & -- & -- & 0.5 \\
\hline $\mathrm{MoO}_{2}$ & 0.40 & 10.9 & -- \\
\hline $\mathrm{NaO}$ & 1.45 & 5.68 & $\ldots$ \\
\hline $\mathrm{SiO}_{2}$ & 1.51 & 23 & 40 \\
\hline $\mathrm{TiO}_{2}$ & -- & 0.67 & 0.24 \\
\hline
\end{tabular}




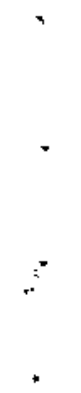


APPENDIX B

VITRIFICATION PROCESS EQUIPMENT COMPONENT TESTING PLAN 
HWVP VITRIF ICATION EQUIPMENT COMPONENT

TESTING PLAN

\section{INTRODUCTION}

This plan provides the objectives and descriptions for the remote features testing of the vitrification equipment components that will be perforred to support design of the Hanford Waste Vitrification Plant equipment. The overall objective of this effort is to verify viability of current concepts for the remote installation, removal, and operation of the melter, turntable and associated equipment. All tests will be performed in accordance with formal test procedures. The test procedures are to be approved by the appropriate Task Leaders, Responsible Test Engineer, and the Quality Engineer. Test results will be evaluated and documented as appropriate. 
TURNTABLE TESTING

The conceptual design of the turntable for canister handing incorporates a variety of features to facilitate remote operation and maintenance. These features, together with the overall functioning of the turntable, require operational verification. To test these features, the following equipment systems will be designed, fabricated, and tested:

- melter/turntable support structure

- melter shell

- turntable drive

- turntable assembly

- canisters

\section{Conceptual Turntable Description}

As currently conceived, a four-position turntable will be used to position the canisters under the melter overlow port(s). Each position in the turntable is equipped with a permanent thimble. A removable insert (thimble liner) will be placed in each thimble to position the canisters during filling and to provide any necessary insulation. In the test turntable, the position under the overflow port will be equipped with a load cell to monitor canister weight during filling.

The turntable will be inside a tank that is connected to the melter overflow port(s). Access to the turntable for installation and removal of canisters will be via a hatch that is equipped with an easily-removed cover employing a water seal; a secondary seal will also be provided to minimize air inleakage during periods when the hatch cover is removed.

With this arrangement, the canister is vented to the melter at all times while it is in the turntable. As a result, no direct connection between the melter and the canister is required during canister filling or cooldown; however, it will be necessary for the canisters to be accurately positioned under the melter overflow ports.

Turntable Testing Plans

Testing planned for the turntable are discussed below. 
Melter to Turntable Connection

Air inleakage to the melter discharge section can lead to glass pouring problems such as stringing. For this reason, it is especially important to minimize inleakage at the connection between the melter and turntable. The location of this connection makes replacement or maintenance of a seal very difficult. The connection designs that appear to be most promising consist of either a liquid metal seal or a flexible metal "E" seal housed in an expandable metal bellows. A large number of low melting points metals exists that could potentially provide this type of seal. After an evaluation of these metals, several will be selected for testing to help determine the most appropriate one.

Tests that will be performed are:

- screening tests to select candidate metals to provide the seal.

- ability of selected materials to form air seal in mock connection apparatus

- remote making and breaking of the seal

- thermal expansion and stress analysis versus number of melter/ freeze cycle.

Tc evaluate the effectiveness and remote handling of a flexible metal seal, a prototype metal bellows and "E"-seal system will be built and tested. Tests that will be performed are:

- remote making and breaking of seal

- measure effectiveness of seal

- remote handling of bellows mechanism

Continuous Weighing of Canisters During Filling

A weighing system is required in the two canister-fill positions to continuously monitor the canister weight during filling. A load cell, located in easily accessible locations outside the turntable tank, will be provided for this purpose. Specific tests that are required and will be conducted are:

- evaluate weighing system accuracy 
- operation of the canister weighing system in conjunction with turntable operation

- demonstration of remote placement of the load cells. Secondary Seal on Turntable Access Hatch

A secondary seal will be provided on the turntable access hatch to restrict air inleakage when the turntable hatch cover is removed.

The following tests will be performed to verify feasibility of the current concept for the secondary seal:

- ability of seal to satisfactorily restrict air inleakage

- durability of seal in operation

- remote replacement of seal assembly.

Overall Operability

To verify overall remote operability of the turntable, the following features will be tested:

- ability of turntable to reliably and consistently position the canisters under the melter overflow

- remote replacement of turntable drive limit switch

- installation and removal of the turntable drive mechanism

- remote replacement of the canister anticontamination shield

- remote replacement of the thimble inserts

- remote operation of the hatch cover

- remote removal of turntabie from under the melter. 
MELTER SERVICES TESTING

Services have been developed to varying degrees to facilitate remote melter operation and maintenance. Installation, removal, and testing of the following components will be performed to verify satisfactory performance for the vitrification system.

- melter discharge section conical insert

- thermocouple connector assembly

- melter overflow section electrical connector assembly

- television jumper assembly (existing unit will be modified)

- overflow heater assembly

- nozzle cleaner (existing unit will be modified)

The melter shell, provided as part of the turntable testing, will incorporate features compatible with testing of the above systems. Melter Services Testing Plans

The testing plans for the melter services are discussed below. Thermocouples and Thermocouple Wells

With the current concepts, remote maintenance on these $i$ tems should be quite simple; however, this will be verified by performing tests with a simple mockup.

Tests that will be performed are:

- remote installation and removal of a modified connector

- measurement of temperatures with the remotely-connected assembly to determine operability and reliable signal transmission. Electrical Connections for Overflow Heaters

Current plans are to use modified Hanford or Purex connectors on the overflow heater electrical leads. The same type of connector is proposed for the thermocouple connections; only the connector pins are different. As a result, remote test of only one connector may suffice.

Tests that will be performed are: 
- characterize the electrical performance of a 20 pin electrical connector.

Nozzle Cleaner

A concept using a core drill has been developed to remove material that has been deposited in the melter nozzles. Testing of this concept has met with only partial success. There has been some equipment failure, and the drill bit had not been completely successful in removing the deposited material. The cleaner assembly is being modified to accommodate water or air flushing of the cutting area to facilitate drill penetration, and new drill bit configurations are planned for testing.

Additional tests that will be performed are:

- use of water flush to remove debris during cutting

- use of inleaking air to remove debris during cutting.

In-Me1ter Viewing

A high-resolution black-and-white TV viewing system is being developed for viewing the interior of the melter during operation. To date, tests of the viewing system are promising. However, additional development work is required to improve picture quality at high melter cavity temperatures and to prevent buildup of particulate material around the periscope viewing port.

Additional tests that will be performed are:

- operation of the modified assembly in the Pilot-Scale Ceramic Melter (PSCM)

- remote installation, removal, and operation of the viewing assembly in the mock system.

Remote Aspects of Overflow Heater Assemblies

It is necessary to protect the overflow heater elements from mechanical damage during installation of the heater assembly. An existing prototype of the heater assembly will be modified so that remote installation tests can be performed to verify adequacy of current concept.

Tests that will be performed are: 
- remote installation and removal of the overflow heater assembly

- determination of air inleakage into the melter from installed overflow assembly.

Discharge Section Temperature Distribution

Heat transfer and thermal stress analys is of the discharge section will help to design the glass leakage dam and trough heating system. To verify the design, a mockup of the discharge section will be fabricated and tested under operating temperature conditions.

Tests to be performed are:

- verify proper heater placement for uniform trough heating, and thermowell placement for accurate control

- thermal cycle of the overflow section to verify that any induced stresses are acceptable. 
Development and testing of several support systems is required. These needs and test plans are discussed below:

Glass Samples

A glass sampling device that fits in the top of the canister has previously been developed and demonstrated. Modifications, as required to fit the current HWVP canisters, will be made to the sampler. Tests will be performed on the modified samplers to demonstrate feasibility of remote removal of the sampler from the canisters with a crane. It is assumed that after the sample is removed from the canister, manipulators can be used to place the' sample in container for transport to the analytical laboratory. Mobile Cobalt Source for Gamma Glass Level Detection System

A device is required to raise and lower a cobalt source along with the axis of the glass canister to provide a radiation source for the garma glass level detection system. A device will be designed and fabricated to determine the feasibility of remotely installing the cobalt source on the assembly, and the ability to reliably and accurately move the source, as required.

Tests that will be performed are:

- remote installation, removal, and mechanical operation of the test assembly

\section{HIGH BAY MODIF ICATIONS}

The following High Bay modifications will be necessary to accommodate the testing activities:

- A partial wall, including a window frame(s) to simulate viewing conditions that an operator would experience while performing remote operations, will be installed to provide the capability to perform remote test operations. The wall will have the flexibility of having manipulators installed to verify the use of manipulators for performing various maintenance functions. 
- The High Bay crane controls will be modified to duplicate an operator's capability to install, remove, and operate equipment pieces in the cell. The capability for remote viewing will be installed for use during remote tests.

- The HBE crane will be modified to incorporate a variable-speed hook and a rotating load hook will be fabricated and installed. 


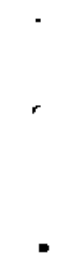

$r$

,

เ 


\section{DISTRIBUTION}

No. of

Copies

OFFSITE

30 DOE Technical Information Center

Nuclear Regulatory Commission

ATTN: R. E. Cunningham

7915 Eastern Avenue

Silver Springs, MD 20910

Nuclear Regulatory Commission

ATTN: J. Roberts

7915 Eastern Avenue

Silver Springs, MD 20910

R. D. Smith

Division of Waste Management

Nuclear Regulatory Commission

Washington, OC 20555

D. M. Rohrer

Office of Inspection and Enforcement

Nucletar Regulatory Commission

MS359 EW/W

Washington, DC 20555

Materials Section Leader

High-Level Waste Licensing Branch

Nuclear Regulatory Commission

washington, DC 20555

W. F. Holcomb

Environmental Protection Agency

Office of Radiation Programs

Washington, DC 20460

W. E. Mott

Office of Environment, Safety and Health

DOE Office for Policy, Safety and Environment

PE-24

Washington, DC 20545
No. of

Copies

DOE Terminal Waste Disposal and Remedial Action

ATTN: J. E. Baublitz, NE-24

GTN

Washington, DC 20545

DOE Terminal Waste Disposal and Remedial Action

ATTN: J. A. Coleman, NE-25

GTN

Washington, DC 20545

DOE Terminal Waste Disposal and Remedial Action

ATTN: D. J. MCGoff, NE-23

GTN

Washington, DC 20545

DOE Terminal Waste Disposal and Remedial Action

ATTN: $H . R$. Voigt, NE-20

GTN

Washington, DC 20545

DOE Office of Defense Waste and Byproducts Management

ATTN: J. E. Dieckhoner, DP-122 GTN

Washington, OC 20545

DOE Office of Defense Waste and Byproducts Management

ATTN: J. J. Jicha, DP-123

GTN

Washington, DC 20545

DOE Office of Oefense Waste and Byproducts Management

ATTN: D. B. Leclaire, DP-12

GTN

Washington, DC 20545

DOE Office of Defense Waste and Byproducts Management

ATTN: T. B. Hindman, Jr. GTN

Washington, DC 20545 
No. of

Copies

Office of Geologic Repositories DOE Office of Civilian Radioactive Waste Management

ATTN: J. W. Bennett, RW-20

RW, GTN

Washington, DC 20545

Office of Geologic Repositories

DOE Office of Civilian Radioactive Waste Management

C. R. Cooley, RW-24

$\mathrm{RW}, \mathrm{GTN}$

Washington, DC 20545

Office of Geologic Repositories

OOE Office of Civilian Radioactive Waste Management

C. H. George, RW-3

RH, GTN

Washington, DC 20545

Office of Geologic Repositories DOE Office of Civilian Radioactive Waste Management

ATTN: R. Stein, RW-21

RW, GTN

Washington, DC 20545

R. Purple

office of Policy, Integration and Outreach

DOE Office of Civilian Radioactive Waste Management

RW-43, Forrestal

Washington, DC 20585

K. 0. Laughon, Sr.

DOE Office of Spent Fuel Management and Reprocessing Systems

NE-40, GTN

Washington, DC 20545

R. Hilley

Office of Storage and Transportation Systems

DOE Office of Civilian Radioactive Waste Management

RW-3D, Forresta 1

Washington, DC 20585
No, of

Copies

S. A. Mann

DOE Chicago Operations Office

9800 South Cass Avenue

Argonne, IL 60439

J. 0. Neff

DOE National Waste Terminal Storage

Program Office

505 King Avenue

Columbus, $\mathrm{OH} 43201$

J. D. Hamric

OOE Idaho Operations Office

$5502 n$ Street

Idaho Falls, ID 83401

Office of the Assistant Manager

for Energy Research and Development

DOE Oak Ridge Operations Office

P.0. Box E

Oak Ridge, TN 37830

S. G. Lane

Nuclear Waste Management Library

Building 830

Brookhaven National Laboratory

Upton, Long Island, NY 11973

Martin Marietta Energy Systems

Oak Rdige National Laboratory

ATTN: W. D. Burch

P.0. Box $X$

Oak Ridge, TN 37831

Martin Marietta Energy Systems

Oak Rdige National Laboratory

ATTN: L. J. Mezga

P.0. Box $X$

Oak Ridge, TN 37831

Martin Marietta Energy Systems Oak Rdige National Laboratory

ATTN: T. H. Row

P.0. Box $X$

Oak Ridge, TN 37831

D. T. Oakley

Los Alamos National Laboratory

P.0. Box 1663

Los Alamos, NM 87545 
No. of

Copies

DOE Savannah River Operations Office ATTN: H. L. Brandt

P.0. Box A

Aiken, SC 29801

DOE Savannah River Operations Office. ATTN: W. J. Brumley

P.0. Box A

Aiken, SC 29801

Westinghouse Idaho Nuclear $\mathrm{Co}$.

ATTN: M. P. Johnson

P.0. Box 4000

Idaho Falls, ID 83401

Westinghouse Idaho Nuclear Co.

ATTN: File Copy

P.0. Box 4000

Idaho Falls, ID 83401

E. A. Jennrich

EG\&G Idaho

P.0. Box 1625

Idaho Falls, ID 83415

S. j. Harbison

DOE San Francisco Operations

1333 Broadway

Oakland, CA 94612

DOE Albuquerque Dperations Office

ATTN: J. McGough

P.0. Box 5400

Albuquerque, NM 87115

Argonne National Laboratory

ATTN: M. J. Steindler/

L. E. Trevorrow

9700 South cass Avenue

Argonne, IL, 60439

Battelle Memorial Institute

Office of Nuclear Waste Isolation

ATTN: N. E. Carter

$505 \mathrm{King}$ Avenue

Columbus, $\mathrm{OH} 43201$
No. of

Copies

Battelle Memorial Institute

Office of Nuclear Waste Isolation

ATTN: S. Goldsmith

505 King Avenue

Columbus, $\mathrm{OH} 43201$

L. Smith

Rockwell International

Rocky Flats Plant

P.0. Box 464

Golden, CO 80401

E. I. du Pont de Nemours Company

Savannah River Laboratory

ATTN: E. J. Hennelly

Aiken, SC 29808

E. I. du Pont de Nemours Company

Savannah River Laboratory

ATTN: M. D. Boersma

Aiken, SC 29808

R. Williams

Electric Power Research Institute 3412 Hillview Avenue

P.0. Box 10412

Palo Alto, CA 94304

G. L. Hohmann

Westinghouse Electric Corporation Advanced Energy Systems Div.

WIPP Library

P.0. Box 40039

Albuquerque, NM 87196

J. L. Knabenschuh

Nuclear Fuels Services, Inc.

P.0. Box 191

West Valley, NY 14171

Bechtel National, Inc.

ATTN: 3. L. Jardine

Box 3965

San Francisco, CA 94119

Bechtel National, Inc.

ATTN: W. A. Freeby

Box 3965

San Francisco, CA 94119 
No. of

Copies

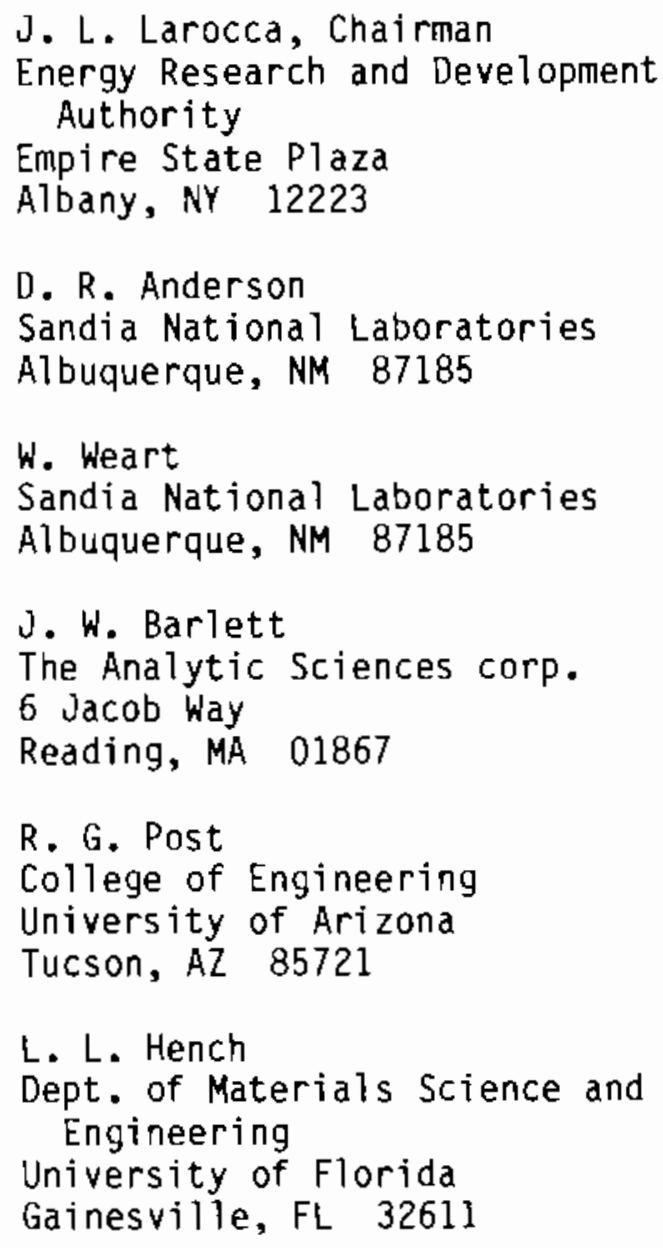

\section{ONSITE}

7 DOE Richland Operations office

E. A. Bracken

J. J. Broderick

J. J. Krupar, Jr.

M. J. Plahuta

H. E. Ransom

M. W. Shupe

J. D. White

15 Rockwell Hanford Operations

R. N. Gurley (6)

H. E. McGuire
No. of

Copies

$\frac{\text { Rockwell Hanford Operations }}{\text { (contd) }}$

R. D. Prosser

J. H. Roecker

P. F. Salter

K. R. Shah

R. J. Thompson

D. D. Wodrich

B. A. Wolfe

File Copy

UNC United Nuclear Industries

T. E. Dabrowski

Westinghouse Hanford Company

A. G. Blasewitz

45 Pacific Northwest Laboratory

D. N. Berger

W. J. Bjorklund/L. K. Holton

H. T. Blair/J. M. Perez

W. F. Bonner

D. J. Bradley

H. C. Burkholder/J. H. Jarrett

J. R. Carrell

T. D. Chikalla

M. S. Hansen

W. 0 . Heath (5)

R. F. Klein

D. E. Knowlton

D. E. Larson

J. M. Latkovich

R. C. Liikala

R. P. Marshal1/D. B. Cearlock

J. L. MCElroy

J. E. Minor

N. M. Sherer

D. H. Siemens (12)

S. L. Stein

R. E. Nightingale/A. M. Platt

W. R. Wiley

Technical Information (5)

Publishing Coordination (2) 